\title{
Kształtowanie kompetencji przedsiębiorczych
}

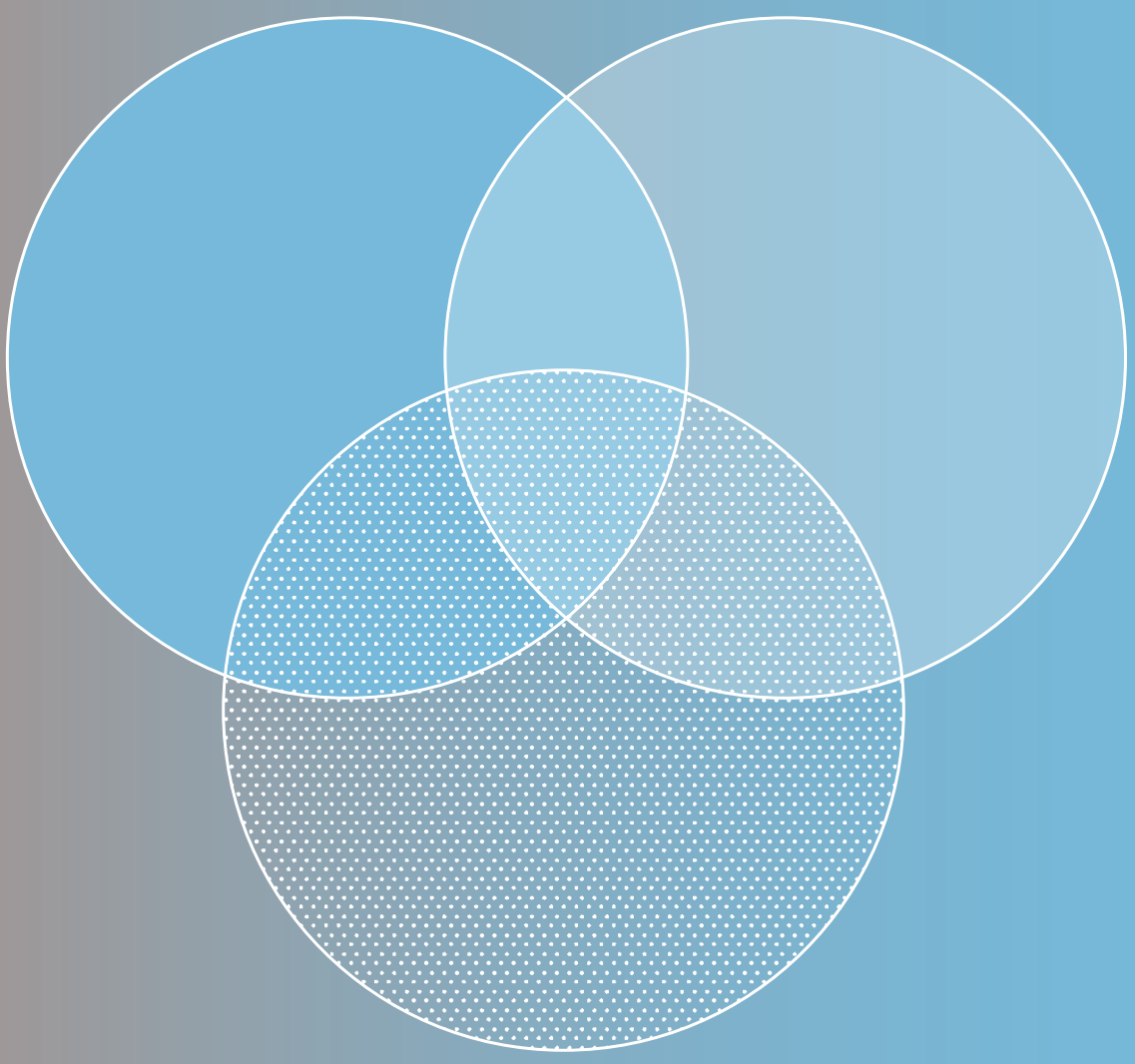


Kształtowanie kompetencji

przedsiębiorczych 



\section{Ksztaltowanie kompetencji przedsiębiorczych}

Obszary:

Przedsiębiorczość jako kompetencja kluczowa

Kształtowanie kompetencji przedsiębiorczych w edukacji

Doświadczenia międzynarodowe w zakresie kształtowania kompetencji przedsiębiorczych

redakcja naukowa

Tomasz Rachwał 
SERIA NAUKOWA, TOM 5

\section{Kształtowanie kompetencji przedsiębiorczych}

Obszary:

Przedsiębiorczość jako kompetencja kluczowa

Kształtowanie kompetencji przedsiębiorczych w edukacji

Doświadczenia międzynarodowe w zakresie kształtowania kompetencji przedsiębiorczych

Redaktor naukowy: $\quad$ dr Tomasz Rachwał

Recenzent: $\quad$ prof. dr hab. Stefan M. Kwiatkowski

Redaktor prowadzący: Radosław Krąpiec

Korekta: Jadwiga Marculewicz-Olaś, Anna Zalewska, Marcin Grabski

Projekt okładki: Mariusz Skarbek

Projekt graficzny: Diana Makulska/Podpunkt

Skład: Artur Ładno, Mariusz Skarbek

Druk: Multigraf Drukarnia Sp. z o.o. Bydgoszcz

Wydawca:

Fundacja Rozwoju Systemu Edukacji Narodowa Agencja Programu Erasmus+ Al. Jerozolimskie 142a, 02-305 Warszawa www.frse.org.pl | kontakt@frse.org.pl

(C) Fundacja Rozwoju Systemu Edukacji, Warszawa 2019

ISBN: 978-83-65591-76-0

Publikacja została wydana przy wsparciu finansowym Komisji Europejskiej w ramach programu Erasmus+. Publikacja odzwierciedla jedynie stanowisko jej autorów i Komisja Europejska nie ponosi odpowiedzialności za zamieszczoną w niej zawartość merytoryczną.

Dziękujemy za współpracę przy powstawaniu publikacji Fundacji Warszawski Instytut Bankowości.

Publikacja bezpłatna

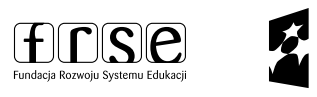

Fundusze Europejskie

Wiedza Eduka

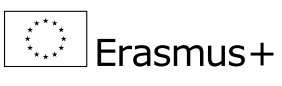

Unia Europejsk Europejski Fundusz Spoteczn

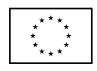

Cytowanie:

Kształtowanie kompetencji przedsiębiorczych, red. nauk. Tomasz Rachwał, Fundacja Rozwoju Systemu Edukacji, Seria Naukowa, t. 5, Warszawa 2019

Dotychczas w ramach Serii Naukowej ukazały się:

Tom 1: Teacher Education Policy and Practice - International Perspectives and Inspiration

Tom 2: Przywództwo nauczycieli

Tom 3: Kompetencje przyszłości

Tom 4: Przestrzenie i miejsca edukacji dorosłych w Polsce

Publikacje dostępne są na stronie czytelnia.frse.org.pl 


\section{Spis treści}

9

Wprowadzenie

Przedsiębiorczość jako kompetencja kluczowa

16

Przedsiębiorczość jako kompetencja kluczowa w systemie edukacji

Tomasz Rachwat

36

Geneza i ewolucja pojęcia przedsiębiorczości

Piotr Komraus

50

Przedsiębiorczość a innowacyjność - rozumienie i delimitacja pojęć

Piotr Kopyciński

64

Kształtowanie przedsiębiorczości jako narzędzie uwalniania potencjału gospodarczego społeczeństwa i rozwoju społeczno-gospodarczego

Wojciech Piontek

80

Znaczenie wiedzy finansowej dla rozwoju przedsiębiorczości Krzysztof Pietraszkiewicz 


\section{Kształtowanie kompetencji przedsiębiorczych w edukacji}

96

Etyka korczakowska a duch przedsiębiorczości

Wojciech Lasota

108

Bankructwo małego Dżeka Janusza Korczaka jako studium przedsiębiorczości

Zygmunt Kawecki

122

Przedsiębiorczość w edukacji przedszkolnej i szkole podstawowej w warunkach zmian podstawy programowej Wioletta Kilar, Tomasz Rachwat

142

Wolontariat szkolny jako narzędzie rozwoju kompetencji przedsiębiorczych

Renata Rettinger

156

Formy i metody kształcenia w zakresie przedsiębiorczości w szkole podstawowej

Anna Śliwińska

168

Pozycja i ranga przedsiębiorczości w edukacji geograficznej w szkole podstawowej w kontekście zmian edukacyjnych Monika Borgiasz-Stepaniuk

186

Przedsiębiorczość w szkole średniej w warunkach reformy systemu oświaty

Wioletta Kilar, Tomasz Rachwat 
204

Przedsiębiorczość w kształceniu studentów, dorosłych i seniorów

Grażyna Nowaczyk, Anna Sobczak

\section{0}

Dobre praktyki edukacji pozaformalnej

Renata Rettinger

234

Metody i formy kształcenia w zakresie innowacyjnej przedsiębiorczości

Agnieszka Skala

252

Przedsiębiorczy nauczyciel

Anna Śliwińska

266

Wpływ zagranicznych mobilności edukacyjnych na rozwój postaw przedsiębiorczych

Mateusz Jeżowski, Michał Pachocki, Agnieszka Rybińska

Doświadczenia międzynarodowe w zakresie kształtowania kompetencji przedsiębiorczych

284

Kompetencja kluczowa czy przedmiot szkolny? Nauczanie przedsiębiorczości w szkołach w Europie

Magdalena Górowska-Fells, Beata Ptatos

302

Edukacja w zakresie przedsiębiorczości we Francji

Stawomir Dorocki, Pawet Brzegowy, Marek Ziarko 
Edukacja w zakresie przedsiębiorczości na poziomie akademickim w Republice Korei

Julita Majczyk

\section{8}

Rola przedsiębiorczości imigrantów w rozwijaniu postaw przedsiębiorczych kraju przyjmującego

Agnieszka Brzozowska 


\section{Wprowadzenie}

Współczesne procesy rozwoju społeczno-gospodarczego, związane z wchodzeniem w informacyjną fazę rozwoju cywilizacyjnego i budową gospodarki opartej na wiedzy, stawiają przed systemami oświaty szczególne wyzwania edukacyjne, związane z przygotowaniem dzieci i młodzieży do dorosłego życia w nowych, dynamicznie zmieniających się warunkach otoczenia. Wyzwania te są jeszcze bardziej doniosłe w Polsce, w której warunki życia kształtowane są nie tylko przez ogólne procesy przemian cywilizacyjnych i impulsy płynące $z$ otoczenia międzynarodowego. Ciągle istotne znaczenie mają procesy transformacyjne, związane z odejściem od gospodarki centralnie sterowanej i budową gospodarki opartej na regułach rynkowych, a także procesy integracji krajowych struktur społeczno-gospodarczych ze strukturami rozwiniętych państw Unii Europejskiej. W warunkach jednolitego wspólnego rynku presja konkurencyjna, w której funkcjonują krajowe przedsiębiorstwa, jest duża, co wynika z ciągle istniejącej przewagi zagranicznych korporacji międzynarodowych, w efekcie ich rozwoju po drugiej wojnie światowej w warunkach konkurencyjnej gospodarki rynkowej i możliwości większej akumulacji zasobów kapitałowych i technologicznych. Zwiększa to ich zdolność do przyciągania najlepszych zasobów kapitału ludzkiego i prowadzenia zaawansowanej działalności innowacyjnej, tak ważnej w gospodarce opartej na wiedzy. Jednocześnie postęp technologiczny powoduje, że presji konkurencyjnej poddane są też poszczególne jednostki na rynku pracy. Mimo stosunkowo dobrej obecnie sytuacji w Polsce w zakresie zatrudnienia z punktu widzenia pracobiorców na atrakcyjne, porównywalne z krajami wysokorozwiniętymi gospodarczo, warunki zatrudnienia mogą liczyć tylko osoby o wysokich kompetencjach ogólnych i zawodowych. Ponadto, pomimo niskich wskaźników bezrobocia, 
na rynku pracy ciągle są osoby, które nie mogą znaleźć zatrudnienia, a pracodawcy odczuwają deficyt kandydatów do pracy o odpowiednich kompetencjach. W tej sytuacji konieczne jest wykształcenie kompetentnego, przedsiębiorczego człowieka, który sprosta tym wyzwaniom i będzie stanowił filar nie tylko organizacji (przedsiębiorstwa lub instytucji), dla której będzie pracował czy którą założy i poprowadzi, lecz także rodziny jako członek gospodarstwa domowego i w końcu filar gospodarki zarówno w skali lokalnej oraz regionalnej, jak i krajowej.

W funkcjonowaniu systemu edukacji znaczącą rolę odgrywa kształtowanie kompetencji przedsiębiorczych, które powszechnie uznaje się za kluczowe w rozwoju osobistym (zarówno prywatnym, jak i zawodowym) każdego człowieka oraz rozwoju społeczno-gospodarczym. Ma to szczególne znaczenie w Polsce, gdzie strategicznym celem polityki społeczno-gospodarczej jest dynamizacja procesów rozwojowych dla podnoszenia poziomu i jakości życia do standardów krajów najwyżej rozwiniętych. Tej doniosłej problematyce poświęcony jest niniejszy tom, kolejny z "Serii Naukowej Wydawnictwa FRSE". Jego autorami są przedstawiciele nie tylko świata nauki o dużym doświadczeniu badawczym, lecz także środowiska oświatowego i praktyki gospodarczej, przez co spojrzenie na proces kształtowania postaw przedsiębiorczych ma wymiar zarówno teoretyczny, jak i aplikacyjny.

W pierwszej części autorzy wykazują, że przedsiębiorczość jest kompetencją kluczową w europejskim systemie edukacji, i wskazują, jak ewoluuje to pojęcie wraz z procesami rozwoju cywilizacyjnego (T. Rachwał, P. Komraus). Rozpatrywane jest to następnie w relacji do pojęcia innowacyjności, ściśle związanej z przedsiębiorczością, a często wskazywanej jako jej nieodłączny element (P. Kopyciński). Kształtowanie kompetencji przedsiębiorczych w systemie edukacji powinno być otoczone szczególną troską ze strony państwa, gdyż przynosi nie tylko korzyści osobiste, lecz także dla rozwoju społeczno-gospodarczego, poprzez uwalnianie potencjału gospodarczego społeczeństwa (W. Piontek). Niezmiernie ważna przy tym jest świadomość znaczenia wiedzy finansowej dla rozwoju przedsiębiorczości, głównie w zakresie zasilania finansowego działalności gospodarczej z różnych źródeł, ale także w funkcjonowaniu gospodarstw domowych, szczególnie w warunkach kryzysów gospodarczych i turbulencji na rynkach finansowych (K. Pietraszkiewicz). 
Druga część monografii odnosi się do kształtowania postaw przedsiębiorczych w edukacji formalnej na różnych poziomach (od przedszkola przez szkołę podstawową i średnią do kształcenia uniwersyteckiego i pozaformalnego). Rozpoczynają ją niezwykłe inspiracje, prawie sprzed 100 lat, jakie płyną $w$ tym zakresie $z$ prac wybitnego wychowawcy i-jak wykazują autorzy - także doskonałego nauczyciela przedsiębiorczości Janusza Korczaka (W. Lasota, Z. Kawecki). Szczególnie ciekawym źródłem może być powieść Bankructwo małego Dżeka, która - choć napisana 95 lat temu w okresie reformy monetarnej W. Grabskiego - stanowi wyjątkowo aktualne studium przedsiębiorczości. Nawiązuje to do projektu edukacji w zakresie przedsiębiorczości (realizowanego przez Fundację Warszawski Instytut Bankowości z grupą partnerów), dla którego ta młodzieżowa powieść stanowi inspirację. Korczakowska wizja wychowania, etyka i duch przedsiębiorczości znajdują swoje odbicie także w reformie programowej edukacji w zakresie przedsiębiorczości. Już od najmłodszych lat, tj. od wychowania przedszkolnego, w świetle zapisów podstawy programowej powinny być kształtowane elementy kompetencji przedsiębiorczych (W. Kilar, T. Rachwał), wśród których duże znaczenie mają: poczucie własnej wartości, samorozwój, branie odpowiedzialności za własne decyzje, komunikacja i współpraca w grupie oraz elementy wiedzy ekonomicznej i finansowej, tak ważne nie tylko w warunkach współczesnych, lecz także w koncepcji wychowania Korczaka. Rozwój kompetencji przedsiębiorczych może być znakomicie wspierany przez wolontariat szkolny (R. Rettinger). Jest to szczególnie ważne w przypadku dzieci i młodszej młodzieży, które z oczywistych powodów nie mogą zdobywać doświadczenia w ramach stosunku pracy czy we własnym biznesie. Niezwykle ważny w procesie kształtowania tych kompetencji jest odpowiedni dobór form i metod kształcenia, szczególnie na początkowych etapach kształcenia (A. Śliwińska). Należy też zwrócić uwagę, że jest to zadanie dla nauczycieli wszystkich przedmiotów szkolnych, nie tylko przedsiębiorczości. Szczególną rolę w tym zakresie może odgrywać nauczyciel geografii (M. Borgiasz). Wynika to $z$ faktu wielu korelacji międzyprzedmiotowych między edukacją geograficzną a przedsiębiorczością. W rozwoju kompetencji przedsiębiorczości w polskim systemie oświaty szczególną rolę odgrywa szkoła średnia. Polska jest ciągle jednym ze stosunkowo niewielu krajów europejskich, w których przedsiębiorczość jest przedmiotem szkolnym kształcenia ogólnego, obowiązkowym dla wszystkich 
uczniów. Jego zakres jest definiowany dosyć szeroko, gdyż pełni on także funkcje w zakresie podstaw edukacji ekonomicznej i finansowej. Analiza zmian podstawy programowej wskazuje, że wzmocniono te treści kształcenia, które są ważne z punktu widzenia przygotowania młodzieży do życia we współczesnym świecie, oraz położono większy nacisk na rozwój umiejętności i kształtowanie postaw uczniów (W. Kilar, T. Rachwał). Rozwój kompetencji przedsiębiorczych nie powinien kończyć się na tym etapie edukacji, ale być kontynuowany na szczeblu uniwersyteckim i być obecny także w edukacji dorosłych i seniorów, w świetle koncepcji uczenia się przez całe życie (G. Nowaczyk, A. Sobczak). Niezmiernie istotne jest tutaj, aby nie ograniczało się to tylko do edukacji formalnej, lecz także dotyczyło edukacji pozaformalnej, w ramach której mamy dużo przykładów dobrych praktyk ( $R$. Rettinger). W warunkach szybkiego postępu technologicznego i rozwoju gospodarki opartej na wiedzy szczególnego znaczenia nabiera kształcenie w zakresie innowacyjnej przedsiębiorczości, gdzie podstawowym problemem jest dobór odpowiednich metod i form kształcenia, często różnych od tych tradycyjnych (A. Skala). W procesie tym główną rolę odgrywa przedsiębiorczy nauczyciel, w którego rękach spoczywa duża odpowiedzialność za efekty kształtowania kompetencji uczniów (A. Śliwińska).

W trzeciej części publikacji zaprezentowano wybrane doświadczenia międzynarodowe w zakresie rozwoju kompetencji przedsiębiorczych. Na początku wykazano, że pozytywny wpływ na kształtowanie tych kompetencji może mieć zagraniczna mobilność edukacyjna, współfinansowana często ze środków unijnych (M. Jeżowski, M. Pachocki, A. Rybińska). Poprzez realizację swoich celów operacyjnych europejskie programy edukacyjne nie tylko wspierają działania nastawione na rozwój umiejętności zdobywanych w ramach kształcenia formalnego, lecz także pomagają zdobyć szereg kompetencji miękkich i społecznych w ramach wyjazdów zagranicznych i innych form kontaktów międzynarodowych. W tej sytuacji warte poznania są podejścia do nauczania przedsiębiorczości w różnych krajach europejskich (M. Górowska-Fells, B. Płatos). Doświadczenia te, przy uwzględnieniu specyficznych warunków krajowych, mogą być wykorzystane w podnoszeniu jakości edukacji w zakresie przedsiębiorczości w Polsce. Jednakże polskie doświadczenia mogą być niezwykle cenne dla innych krajów, szczególnie tych, w których do tej pory nie kładło się dużego nacisku na rozwój kompe- 
tencji przedsiębiorczych. W kolejnych pracach zaprezentowano bardziej szczegółowo doświadczenia w tym zakresie z Francji (S. Dorocki, P. Brzegowy, M. Ziarko) oraz na poziomie akademickim z Republiki Korei (J. Majczyk). W końcowym rozdziale wskazano na rolę przedsiębiorczości imigrantów w rozwijaniu kompetencji przedsiębiorczych kraju przyjmującego, wskazując na przykłady pozytywnych doświadczeń w tym zakresie (A. Brzozowska).

Mamy nadzieję, że lektura niniejszej monografii będzie dla Czytelników nie tylko źródłem wiedzy, lecz także inspiracją do dalszych dyskusji naukowych i bardziej owocnego kształtowania kompetencji przedsiębiorczych dzieci, młodzieży i dorosłych.

dr Tomasz Rachwał redaktor naukowy 


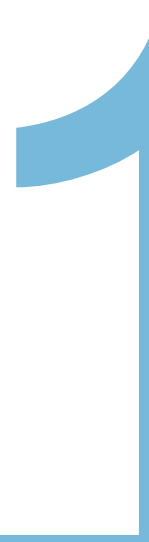

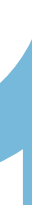




\section{Przedsiębiorczość jako kompetencja kluczowa}




\section{Przedsiębiorczość jako kompetencja kluczowa w systemie edukacji}

Tomasz Rachwał

Przedsiębiorczość jest pojęciem wieloznacznym i różnie definiowanym na gruncie poszczególnych dyscyplin naukowych, dla których stanowi ona przedmiot badań. W efekcie nie ma jednej, powszechnie akceptowanej definicji przedsiębiorczości. O ile w dyskursie naukowym taki stan rzeczy należy traktować jako normalny, to wydaje się, że na potrzeby edukacyjne konieczne jest przyjęcie jednej wspólnej definicji. Umożliwia to bowiem budowanie skutecznych strategii edukacyjnych, formułowania podstaw programowych i programów nauczania, w ramach których będziemy zgodni jakie konkretnie kompetencje przedsiębiorcze uczniów chcemy kształtować. Jedną z takich możliwości jest przyjęcie europejskiej koncepcji przedsiębiorczości jako kompetencji kluczowej. $\mathrm{W}$ rozdziale na tle literatury przedmiotu przedstawiono zmiany w zakresie deskrypcji przedsiębiorczości jako jednej z ośmiu kompetencji kluczowych w europejskim systemie edukacji.

\section{Słowa kluczowe:}

edukacja w zakresie przedsiębiorczości

kompetencje kluczowe

kompetencje w zakresie przedsiębiorczości

przedsiębiorczość

system edukacji 


\section{Entrepreneurship as a key competence in education system}

Tomasz Rachwał

Entrepreneurship is an ambiguous concept, variously defined on the basis of individual scientific disciplines for which it is the subject of research. As a result, there is no single widely accepted definition of entrepreneurship. While in the scientific discourse this status should be treated as normal, it seems that for educational purposes it is necessary to adopt one common definition. This allows for building effective educational strategies, formulating core and school curricula, within which we will agree on what specific entrepreneurial competences of pupils we want to develop. One of these possibilities is the adoption of the European concept of entrepreneurship as key competence. On the background of the literature on the subject this chapter refers to the presents changes in the scope of the description of entrepreneurship as one of the eight key competences in the European education system. 


\section{Wstęp}

Przedsiębiorczość jest w ostatnich latach niezmiernie popularnym pojęciem w dyskursie zarówno społecznym jak i naukowym. Można nawet powiedzieć, że stała się niezwykle modna. Pojawia więc coraz więcej różnego typu „przedsiębiorczych" projektów czy strategii i programów mających na celu jej rozwój. Wynika to z faktu, że powszechnie uznaje się jej dużą rolę w życiu człowieka, społeczeństwa, funkcjonowaniu gospodarki i jej podmiotów, w szczególności przedsiębiorstw i rożnego typu instytucji. Przymiotnik "przedsiębiorczy” odnosi się już nie tylko człowieka, ale też do organizacji, w tym przedsiębiorstw i uniwersytetów (Wach 2014a, Zioło 2016), a także układów przestrzennych - regionów (Godlewska-Majkowska 2015, Pilewicz 2012, Płaziak, Rachwał 2015) czy miast (Szromnik 2012), a nawet całej gospodarki (Wach 2014b). Powoduje to, że w literaturze przedmiotu pojawia się wiele jej definicji, w zależności od celów i przedmiotu rozważań podejmowanych przez różnych autorów. Konieczne jest jednak przyjęcie dla celów edukacyjnych w miarę spójnego, jednego spojrzenia na przedsiębiorczość. W przeciwnym razie niezmiernie trudno będzie konstruować skuteczne strategie i programy edukacji w zakresie przedsiębiorczości lub będą one realizować zbyt różne, odległe od istoty przedsiębiorczości cele, czasem nawet sprzeczne ze sobą. Dlatego też głównym celem niniejszego tekstu jest wykazanie możliwości przyjęcie na potrzeby edukacyjne europejskiej definicji przedsiębiorczości jako kompetencji kluczowej, analiza zmian jej szczegółowej deskrypcji w ostatnich latach na tle dyskusji w literaturze przedmiotu odnoszącej się do miejsca przedsiębiorczości w systemie kompetencji.

\section{Pojmowanie przedsiębiorczości na gruncie różnych nauk a potrzeby edukacyjne}

Powszechnie przyjmuje się, że przedsiębiorczość jest pojęciem polisemicznym, ale też nie zawsze właściwie rozumianym, w wyniku traktowania jej zbyt wąsko lub zbyt szeroko, a czasem nawet wkładania weń sprzecznych treści (Brzozowski 2007). Niewątpliwie jest ona zjawiskiem bardzo złożonym i wielowymiarowym, o czym zdaniem J. Cieślika (2014, s.19), „świadczy fakt, że mimo prowadzonych od XVIII w. badań, w gronie naukowców zajmujących się tą problematyką występuje nadal wiele kontrowersji i wątpliwości, dotyczących fundamentalnych kwestii - począwszy od definicji przedsiębiorcy oraz interpretacji przedsiębiorczości 
jako zjawiska społeczno-gospodarczego". Nie ma także nawet zgody co do umiejscowienia przedsiębiorczości jako subdyscypliny naukowej, przypisywanej zarówno do nauk w zakresie zarządzania, ekonomii, geografii społeczno-ekonomicznej, jak i socjologii, psychologii, historii i innych dyscyplin, dla których również stanowi przedmiot badań (Cieślik 2014, 2015, Rachwał 2018, Wach 2014c, 2015). Odmienność spojrzeń przedstawicieli różnych dyscyplin na przedsiębiorczość wpływa na różne jej ujęcia i różne podejścia badawcze. Przykładowo w naukach o zarządzaniu duże znaczenie ma ujęcie przedsiębiorczości jako procesu (Gaweł 2013, Glinka, Gudkova 2013), w publikacjach ekonomicznych problematyka przedsiębiorczości często koncentrowana jest na kwestii samozatrudnienia czy sektora małych i średnich przedsiębiorstw (Wach 2015). W dodatku w warunkach polskich należy uwzględnić wciąż istniejącą dotkliwą luką badawczą w dziedzinie przedsiębiorczości powstałą w naszym kraju w ciągu dziesięcioleci gospodarki socjalistycznej (Kraśnicka 2011). W geografii społeczno-ekonomicznej kładzie się z kolei nacisk na przestrzenne aspekty rozwoju przedsiębiorczości i jej rolę w aktywizacji gospodarczej i rozwoju układów przestrzennych różnej skali, od lokalnej, przez ponadlokalną i regionalną po skalę krajową (Rachwał 2018, Zioło, Rachwał 2012). Należy się więc zgodzić z K. Wachem (2015), że przedsiębiorczość jako obszar badawczy cechuje wyjątkowa multidyscyplinarność, co oznacza, że badania prowadzone w wielu dyscyplinach naukowych odrębnie i interdyscyplinarność (badania na styku co najmniej dwóch dyscyplin naukowych). Dynamiczny rozwój badań nad przedsiębiorczością i szeroka dyskusja w obrębie oraz na styku wielu dyscyplin naukowych powoduje, że to fundamentalne pojęcie definiowane jest $w$ niejednolity sposób i nie ma powszechnej zgody na jedną definicję przedsiębiorczości. Nie zmienia to jednak faktu, że konieczne jest jej zdefiniowanie na potrzeby edukacji. Jeśli jesteśmy zgodni, że przedsiębiorczość zajmuje lub powinna zajmować znaczące w niej miejsce, to nie można zadowolić się stwierdzeniami, że jest to pojęcie wieloznaczne, a każdy z autorów przyjmuje własną definicję. Nie jest też możliwe bezpośrednie przeniesienie definicji z jednej z nauk, zresztą nawet w poszczególnych dyscyplinach naukowych trudno mówić nawet o powszechności jednej z definicji, a tym bardziej pełnej dla niej akceptacji. Jednak budowanie skutecznej strategii kształtowania kompetencji przedsiębiorczych w systemie edukacji od najmłodszych lat wymaga przyjęcia takiego $w$ miarę jednolitego ujęcia 
przedsiębiorczości.Należy mieć bowiem na uwadze, że odbiorcą tej definicji, są nie tyle badacze, ale przede wszystkim decydenci w obszarze edukacji, autorzy podstaw programowych, programów nauczania i podręczników oraz nauczyciele i wreszcie - sami uczniowie. Ważne jest tu przyjęcie pewnej bazy pojęciowej do podejmowanych działań edukacyjnych w tym zakresie, szczególnie w ramach edukacji formalnej, ale także pozaformalnej i nieformalnej, tak istotnych w erze dynamicznych przemian społeczno-gospodarczych i turbulencji otoczenia.

\section{Przedsiębiorczość jako kompetencja}

Jeszcze stosunkowo niedawno pojęcie kompetencji było definiowane jako nadany, na podstawie faktycznych kwalifikacji, zakres pełnomocnictw i uprawnień. Takie ujęcie powodujące swoistą nadrzędność kompetencji nad kwalifikacjami wciąż obowiązuje w niektórych profesjach (Kwiatkowski 2018). Tego typu podejścia definicyjne spotykane są nadal w opracowaniach branżowych i słownikach językowych (np. "Słownik języka polskiego", 2005). Współcześnie przyjmuje się jednak szersze ujęcie tego pojęcia, szczególnie w odniesieniu do efektów uczenia się w różnych formach edukacji. W ich skład wchodzą (Kwiatkowski 2018):

$\rightarrow$ wiedza, a więc zbiór faktów, praw, teorii, zasad i doświadczeń przyswojonych lub samodzielnie skonstruowanych,

$\rightarrow$ umiejętności, a więc zdolność/gotowość do wykorzystania wiedzy podczas realizacji różnego rodzaju zadań,

$\rightarrow$ kompetencje społeczne, w więc zdolność do projektowania i kształtowania własnego rozwoju oraz autonomicznego i odpowiedzialnego udziału w życiu społeczno-zawodowym.

Takie podejście do kompetencji jest powszechnie stosowane w systemach edukacji, zostało między innymi wprowadzone do systemu szkolnictwa w ramach Krajowych Ram Kwalifikacji (obecnie Polskich Ram Kwalifikacji), co znajduje swoje powszechne odzwierciedlenie w zapisach programów studiów, gdzie określa się efekty kształcenia w zakresie wiedzy, umiejętności i kompetencji społecznych. Takie ujęcie kompetencji jest często przyjmowane także na niższych poziomach edukacji, co znalazło również swoje odzwierciedlenie w zapisach podstawy programowej dla szkół podstawowych i średnich z zakresu geografii i podstaw przedsiębiorczości (Rachwał i in. 2018, Szkurłat 
i in. 2018, zob. także kolejny rozdział autorstwa W. Kilar i T. Rachwała). Czasem do tego zestawu trzech podstawowych elementów dodaje się także cechy osobowości.

Warto zwrócić uwagę, za D. Piróg (2015), że termin kompetencja ma wiele znaczeń i choć pojawił się w literaturze naukowej stosunkowo niedawno, stał się przedmiotem badań wielu specjalistów, m.in. z zakresu pedagogiki pracy, polityki społecznej, ekonomii, socjologii, psychologii oraz dydaktyki szkoły wyższej. Zdaniem autorki wielodziedzinowy charakter pojęcia kompetencja skutkuje mnogością spojrzeń na nie i w konsekwencji powstaniem wielu definicji. Różnorodność ta jest również związana ze współwystępowaniem dwóch sposobów rozumienia kompetencji, które w języku angielskim są odzwierciedlone za pomocą słów competency i competence. Autorka wskazuje, że pierwszy termin wywodzi się ze Stanów Zjednoczonych, gdzie kompetencje mają podłoże behawioralne i są ujmowane jako sposób zachowania, który wpływa na powodzenie wykonywanych zadań. $W$ tym rozumieniu kompetencje zbudowane są zazwyczaj ze składowych wiedzy, umiejętności i przejawianych postaw, które to postawy są uzewnętrznioną, wyuczoną - w różnych środowiskach skłonnością człowieka do określonych zachowań i działań. Natomiast inne rozumienie terminu kompetencje mieści się pod wyrazem competence. Termin ten, powstały na gruncie brytyjskim, skupia się na wystandaryzowanych wynikach wykonywanych działań, przypisanych np. do zawodu czy stanowiska pracy (Piróg 2015). To pierwsze podejście zatem odpowiada bardziej temu, co zostało przyjęte w systemie edukacji w ramach kształcenia ogólnego, to drugie bardziej nawiązuje do celów kształcenia zawodowego.

Generalnie ujmując kompetencje można więc podzielić na ogólne i zawodowe. Te pierwsze zalicza się do podstawowych efektów uczenia się w ramach kształcenia ogólnego, które realizowane jest głównie w szkołach podstawowych, liceach ogólnokształcących i częściowo w szkolnictwie zawodowym, gdzie jednak ze zrozumiałych względów większą wagę przywiązuje się do kompetencji zawodowych (Kwiatkowski 2018). Kompetencje ogólne z punktu widzenia edukacyjnego wiążą się przede wszystkim z rozwojem intelektualnym uczniów, a zawodowe są kształtowane w celach związanych z przyszłą pracą. Choć w praktyce gospodarczej kompetencje zawodowe uzyskane podczas formalnej edukacji przyjmują postać kwalifikacji zawodowych i posiadają 
określoną wartość rynkową, w odróżnieniu od większości kompetencji ogólnych, to jednak kompetencje ogólne należy traktować jako fundament kompetencji zawodowych (Kwiatkowski 2018). Wśród kompetencji ogólnych mieści się przedsiębiorczość, która wskazywana jest jako jedna z podstawowych kompetencji z punktu widzenia tranzycji i funkcjonowania jednostki na rynku pracy, podejmowania samozatrudnienia, podnoszenia konkurencyjności przedsiębiorstw oraz procesów rozwoju gospodarczego (Białasiewicz 2008, Korpysa 2013, Kwiatkowski 2018, Piróg 2013, 2014, 2015, 2016, Wach 2013, Zioło 2012, Zioło, Rachwał 2012). Stąd M. Tracz (2006) wskazuje na dużą rolę jej kształtowania w kształceniu ogólnym. Ze względu na rosnące jej znaczenie w obecnej fazie rozwoju cywilizacyjnego jest ona określana także jako kompetencja przyszłości (Borowiec, Kilar, Rachwał 2018).

Powszechnie przyjmuje się, że na przedsiębiorczość jako kompetencję składa się wiele elementów. Wcześniej w literaturze polskiej były one określane jako cechy postawy przedsiębiorczej (Borowiec, Rachwał 2011, Piróg 2015, Rachwał 2005, 2006, Strojny 2007). Stąd należy raczej mówić o kompetencjach przedsiębiorczych czy kompetencjach w zakresie przedsiębiorczości, zatem w liczbie mnogiej. D. Piróg (2015) w wyniku obszernego studium zagranicznej literatury przedmiotu zwróciła uwagę na ewolucję konceptualizacji kompetencji z zakresu przedsiębiorczości oraz zestawu kompetencji, które charakteryzują osobę przedsiębiorczą. W wyniku tego przeglądu autorka uznała, że kompleksową, najnowszą propozycją w tym zakresie jest opracowanie autorstwa S. Mitchelmore i J. Rowley (2010). W wyniku głębokiej analizy literatury zestawiły one 25 kompetencji, które inni specjaliści podejmujący tę problematykę najczęściej uwzględniali w swoich badaniach i podzieliły je na kompetencje osobowościowe (społeczne), behawioralne (osobiste) oraz menadżerskie (Piróg 2015) ${ }^{1}$.

Inny zestaw kompetencji przedsiębiorczych na potrzeby systemu edukacji opracowano w ramach dużego projektu europejskiego wykonanego na zlecenie Komisji Europejskiej EntreComp: The Entrepreneurship Competence Framework. W efekcie jego realizacji opracowano ramy (tj. model koncepcyjny i szczegółową definicję) kom-

1. Klasyfikację i szczegółowy wykaz kompetencji z zakresu przedsiębiorczości na podstawie artykułu S.Mitchelmore i J. Rowley (2010) przedstawiła w swojej pracy D. Piróg (2015, tab. 2, s. 371). 
petencji przedsiębiorczych (Bacigalupo i in. 2016). Ramy te określają przedsiębiorczość jako kompetencję przekrojową, która dotyczy ludzi we wszystkich sferach życia, od rozwoju osobistego przez aktywne uczestnictwo w społeczeństwie, do wejścia/ponownego wejścia na rynek pracy jako pracownik lub osoba samozatrudniona, a także do rozpoczynania różnego typu przedsięwzięć (kulturalnych, społecznych lub gospodarczych). Według wypracowanej koncepcji dzieli się je na trzy kategorie obejmujące: idee i możliwości ich realizacji, zasoby oraz działanie (Bacigalupo i in. 2016, Carlebach 2016, Kwiatkowski 2018). Kompetencje przynależne poszczególnym obszarom są następujące (Bacigalupo i in. 2016):

1) kategoria „idee i możliwości" (ang. ideas and opportunities)

$\rightarrow$ dostrzeganie możliwości,

$\rightarrow$ kreatywność,

$\rightarrow$ tworzenie wizji,

$\rightarrow$ ocena idei (pomysłów),

$\rightarrow$ etyka i „zrównoważone" myślenie (ang. sustainable thinking),

2) kategoria "zasoby" (ang. resources)

$\rightarrow$ samoświadomość i poczucie własnej skuteczności

$\rightarrow$ motywacja i wytrwałość,

$\rightarrow$ mobilizowanie zasobów (pozyskanie i zarządzanie zasobami),

$\rightarrow$ kompetencje związane $z$ wiedzą finansową i ekonomiczną,

$\rightarrow$ mobilizowanie innych.

3) kategoria "działanie" (ang. taking into action)

$\rightarrow$ przejmowanie inicjatywy,

$\rightarrow$ planowanie i zarządzanie,

$\rightarrow$ radzenie sobie z niejednoznacznością, niepewnością i ryzykiem,

$\rightarrow$ umiejętność pracy z innymi (współpracy w zespole),

$\rightarrow$ ciągłe uczenie się poprzez doświadczenie.

Ramy te są ciekawą próbą porządkowania, grupowania i konkretyzowania kompetencji w zakresie przedsiębiorczości i nawiązują do europejskiej definicji przedsiębiorczości jako kompetencji kluczowej.

\section{Europejska koncepcja przedsiębiorczości jako kompetencji kluczowej}

W wyniku wieloletnich prac zespołu roboczego w ramach Komisji Europejskiej przedsiębiorczość uznano za jedną z ośmiu kompetencji klu- 
czowych w procesie uczenia się przez całe życie. Kompetencje kluczowe stanowią połączenie wiedzy, umiejętności i postaw, które wszystkie osoby potrzebują dla samorealizacji i rozwoju osobistego, bycia aktywnym obywatelem, integracji społecznej oraz zatrudnienia (Zalecenie... 2006). Choć z oczywistych względów traktatowych, z których jednoznacznie wynika, że każdy kraj członkowski ma prawo wg swojego uznania kształtować swój system edukacji, jest to tylko „miękki” dokument wspólnotowy, ogłoszony w formie zalecenia Parlamentu Europejskiego i Rady UE, to jednak koncepcja ta jest sukcesywnie wdrażana w krajach Unii Europejskiej. Została ona rozpropagowana w postaci szeregu raportów, dokumentów roboczych i materiałów promocyjnych (m.in. Eurydice, np. Kompetencje kluczowe 2007), dzięki czemu przyjmowana jest ona także, przynajmniej częściowo, nie tylko w krajach członkowskich, ale także innych krajach europejskich, szczególnie Europejskiego Obszaru Gospodarczego, a nawet w krajach pozaeuropejskich.

W wyniku okresowego przeglądu kompetencji po ponad 10 latach wdrażania koncepcji dokonano, zgodnie z założeniami nowego europejskiego programu na rzecz umiejętności, pewnych korekt, wynikających z procesów rozwoju cywilizacyjnego i diagnozy stanu i potrzeb edukacyjnych (Tab. 1). Jak wskazano w nowym Zaleceniu Rady UE (2018, s. 1, par. 4) „obecnie wymagania dotyczące kompetencji uległy zmianie w związku z rosnącą liczbą miejsc pracy poddanych automatyzacji, coraz istotniejszą rolą technologii we wszystkich dziedzinach pracy i życia oraz zwiększającym się znaczeniem kompetencji społecznych, obywatelskich i w zakresie przedsiębiorczości, które pozwalają zapewnić odporność i zdolność dostosowania się do zmian". Jednocześnie zwrócono uwagę, że badania prowadzone w Europie wskazują na utrzymujący się wysoki odsetek nastolatków i dorosłych mających niewystarczające umiejętności podstawowe. W 2015 r. co piąty uczeń miał poważne trudności w osiągnięciu wystarczającego poziomu umiejętności w zakresie czytania ze zrozumieniem, myślenia matematycznego lub rozumienia zjawisk przyrodniczych. W niektórych krajach nawet co trzeci dorosły ma umiejętność rozumienia i tworzenia informacji oraz rozumowania matematycznego jedynie na najniższym poziomie. 44 proc. ludności Unii ma niskie umiejętności cyfrowe, a 19 proc. nie ma ich wcale (Zalecenie... 2018). 
Tabela 1. Kompetencje kluczowe w europejskim systemie edukacji

\begin{tabular}{|c|c|}
\hline $\begin{array}{l}\text { KOMPETENCJE WG "STAREGO" UKŁADU } \\
\text { (ZALECENIE... 2006) }\end{array}$ & $\begin{array}{l}\text { KOMPETENCJE WG „NOWEGO" UKŁADU } \\
\text { (ZALECENIE... 2018) }\end{array}$ \\
\hline 1) porozumiewanie się w języku ojczystym; & \multirow{2}{*}{$\begin{array}{l}\text { 1) kompetencje w zakresie rozumienia i tworze- } \\
\text { nia informacji, } \\
\text { 2) kompetencje w zakresie wielojęzyczności, }\end{array}$} \\
\hline 2) porozumiewanie się w językach obcych; & \\
\hline $\begin{array}{l}\text { 3) kompetencje matematyczne i podsta- } \\
\text { wowe kompetencje naukowo-technicz- } \\
\text { ne; }\end{array}$ & $\begin{array}{l}\text { 3) kompetencje matematyczne oraz kompetencje } \\
\text { w zakresie nauk przyrodniczych, technologii } \\
\text { i inżynierii, }\end{array}$ \\
\hline 4) kompetencje informatyczne; & 4) kompetencje cyfrowe, \\
\hline 5) umiejętność uczenia się; & \multirow{2}{*}{$\begin{array}{l}\text { 5) kompetencje osobiste, społeczne i w zakresie } \\
\text { umiejętności uczenia się, } \\
\text { 6) kompetencje obywatelskie, }\end{array}$} \\
\hline 6) kompetencje społeczne i obywatelskie; & \\
\hline 7) inicjatywność i przedsiębiorczość; & 7) kompetencje w zakresie przedsiębiorczości, \\
\hline 8) świadomość i ekspresja kulturalna & $\begin{array}{l}\text { 8) kompetencje w zakresie świadomości i ekspresji } \\
\text { kulturalnej. }\end{array}$ \\
\hline
\end{tabular}

Źródło: Opracowanie własne na podstawie Zalecenie... (2006) i Zalecenie... (2018).

Jak widać zmiany w zakresie kompetencji w niektórych aspektach są znaczące. Między innymi zrezygnowano z podziału kompetencji językowych na język ojczysty i obcy, zastępujące je kompetencjami w zakresie rozumienia i tworzenia informacji oraz wielojęzyczności. Zmiany takie nie nastąpiły w odniesieniu do przedsiębiorczości, która - jak podkreślono w nowym Zaleceniu (2018) jest jedną z kompetencji, których znaczenie rośnie. Uproszczono słusznie nazwę tej kompetencji, gdyż była nieco myląca. Powszechnie przecież wskazuje się inicjatywność jako cechę (Rachwał 2005, 2006, Borowiec, Rachwał 2011, Borowiec, Kilar, Rachwał 2018) lub składową kompetencji behawioralnych (osobistych) osoby przedsiębiorczej (Piróg 2015). Poprzednia nazwa tej grupy kompetencji, gdzie inicjatywność była współrzędnie połączona z przedsiębiorczością spójnikiem „i" oraz w dodatku występowała na pierwszym miejscu, była więc niezbyt fortunna.

Jeśli chodzi o zmianę samej definicji kompetencji w zakresie przedsiębiorczości, to nie jest ona znacząca w sensie merytorycznym, w porównaniu z głębokimi zmianami w przypadku niektórych innych kompetencji (Tab. 2). Choć nowe ujęcie jest nieco krótsze, to jego sens został zachowany. Zwrócono jednak bardziej uwagę na czym się opierają niż czemu służą. Choć nowe brzmienie wydaje się bardziej konkretne 
i precyzyjne, to za nienajlepsze rozwiązanie należy uznać wyeliminowanie aspektu etycznego podejmowanych działań. Zostało to w zamian mocniej wyakcentowane w dalszej części opisu tej kompetencji.

Tabela 2. Zmiana europejskiej definicji kompetencji

w zakresie przedsiębiorczości

\begin{tabular}{|c|c|}
\hline $\begin{array}{l}\text { INICJATYWNOŚĆ I PRZEDSIĘBIORCZOŚĆ } \\
\text { (ZALECENIE... 2006) }\end{array}$ & $\begin{array}{c}\text { KOMPETENCJE W ZAKRESIE } \\
\text { PRZEDSIĘBIORCZOŚCI (ZALECENIE... 2018) }\end{array}$ \\
\hline $\begin{array}{l}\text { Inicjatywność i przedsiębiorczość oznaczają zdolność } \\
\text { osoby do wcielania pomysłów w czyn. Obejmują one } \\
\text { kreatywność, innowacyjność i podejmowanie ryzyka, } \\
\text { a także zdolność do planowania przedsięwzięć i prowa- } \\
\text { dzenia ich dla osiągnięcia zamierzonych celów. Stanowią } \\
\text { one wsparcie dla indywidualnych osób nie tylko w ich } \\
\text { codziennym życiu prywatnym i społecznym, ale także } \\
\text { w ich miejscu pracy pomagając im uzyskać świadomość } \\
\text { kontekstu ich pracy i zdolność wykorzystywania szans; } \\
\text { są podstawą bardziej konkretnych umiejętności i wiedzy } \\
\text { potrzebnych tym, którzy podejmują przedsięwzięcia } \\
\text { o charakterze społecznym lub handlowym lub w nich } \\
\text { uczestniczą. Powinny one obejmować świadomość war- } \\
\text { tości etycznych i promować dobre zarządzanie. }\end{array}$ & $\begin{array}{l}\text { Kompetencje w zakresie przedsię- } \\
\text { biorczości to między innymi zdolność } \\
\text { wykorzystywania szans i pomysłów } \\
\text { oraz przekształcania ich w wartość dla } \\
\text { innych osób. Przedsiębiorczość opiera } \\
\text { się na kreatywności, krytycznym } \\
\text { myśleniu i rozwiązywaniu problemów, } \\
\text { podejmowaniu inicjatywy, wytrwałości } \\
\text { oraz na zdolności do wspólnego dzia- } \\
\text { łania służącego planowaniu projektów } \\
\text { mających wartość kulturalną, społecz- } \\
\text { ną lub finansową i zarządzaniu nimi. }\end{array}$ \\
\hline
\end{tabular}

Źródło: opracowanie własne na podstawie Zalecenie... (2006) i Zalecenie... (2018).

Druga część definicji kompetencji kluczowych jest charakterystyką niezbędnej wiedzy, umiejętności i postaw powiązane z daną kompetencją. Nowa deskrypcja jest nieco bardziej obszerna od poprzedniej (Tab. 3). Pojawiają się w niej nowe odniesienia do proaktywności (współcześnie niezmiernie ważnej), zdolności do empatii, troski o innych ludzi i świat, a także przyjmowania odpowiedzialności i postaw etycznych. Mocniej wyakcentowano także kwestie rozumienia procesów ekonomicznych, zdolności podejmowania decyzji finansowych, skutecznego komunikowania się i negocjowania z innymi osobami, a także radzenia sobie z niepewnością, dwuznacznością i ryzykiem jako elementami procesu podejmowania świadomych decyzji. 


\section{Tabela 3. Zmiana w zakresie wiedzy, umiejętności i postaw związanych $z$ definicją kompetencji w zakresie przedsiębiorczości}

\begin{tabular}{|c|c|}
\hline $\begin{array}{l}\text { INICJATYWNOŚĆ I PRZEDSIĘBIORCZOŚĆ } \\
\text { (ZALECENIE... 2006) }\end{array}$ & $\begin{array}{l}\text { KOMPETENCJE W ZAKRESIE PRZEDSIĘBIORCZOŚCI } \\
\text { (ZALECENIE... 2018) }\end{array}$ \\
\hline $\begin{array}{l}\text { Niezbędna wiedza, umiejętności i posta- } \\
\text { wy powiązane z tą kompetencją: }\end{array}$ & $\begin{array}{l}\text { Niezbędna wiedza, umiejętności i postawy powiązane } \\
\text { z tą kompetencją: }\end{array}$ \\
\hline $\begin{array}{l}\text { Konieczna wiedza obejmuje zdolność } \\
\text { identyfikowania dostępnych możliwości } \\
\text { działalności osobistej, zawodowej lub } \\
\text { gospodarczej, w tym szerszych zagad- } \\
\text { nień stanowiących kontekst pracy i życia } \\
\text { ludzi, takich jak ogólne rozumienie zasad } \\
\text { działania gospodarki, a także szanse } \\
\text { i wyzwania stojące przed pracodawcami } \\
\text { i organizacjami. Osoby powinny również } \\
\text { być świadome zagadnień etycznych } \\
\text { związanych z przedsiębiorstwami oraz } \\
\text { tego, w jaki sposób mogą one wywo- } \\
\text { ływać pozytywne zmiany, np. poprzez } \\
\text { sprawiedliwy handel lub przedsięwzię- } \\
\text { cia społeczne. }\end{array}$ & $\begin{array}{l}\text { Kompetencje w zakresie przedsiębiorczości wymagają } \\
\text { świadomości istnienia różnych kontekstów i różnych } \\
\text { możliwości pozwalających przekształcać pomysły } \\
\text { w działanie w sferze osobistej, społecznej i zawo- } \\
\text { dowej, a także rozumienia procesu ich powstawania. } \\
\text { Niezbędna jest znajomość i rozumienie podejść do } \\
\text { planowania i zarządzania projektami, obejmują- } \\
\text { cych zarówno procesy, jak i zasoby. Konieczne jest } \\
\text { rozumienie procesów ekonomicznych oraz szans } \\
\text { i wyzwań społecznych i gospodarczych stojących } \\
\text { przed pracodawcą, organizacją lub społeczeństwem. } \\
\text { Niezbędna jest również świadomość zasad etycznych, } \\
\text { wyzwań w zakresie zrównoważonego rozwoju, a także } \\
\text { własnych atutów i słabości. }\end{array}$ \\
\hline $\begin{array}{l}\text { Umiejętności odnoszą się do proak- } \\
\text { tywnego zarządzania projektami (co } \\
\text { obejmuje np. planowanie, organizowa- } \\
\text { nie, zarządzanie, kierowanie i zlecanie } \\
\text { zadań, analizowanie, komunikowanie, } \\
\text { sporządzanie raportów, ocenę i spra- } \\
\text { wozdawczość), skutecznej reprezentacji } \\
\text { i negocjacji oraz zdolności zarówno } \\
\text { pracy indywidualnej, jak i współpracy } \\
\text { w zespołach. Niezbędna jest umiejęt- } \\
\text { ność oceny i identyfikacji własnych } \\
\text { mocnych i słabych stron, a także oceny } \\
\text { ryzyka i podejmowania go w uzasadnio- } \\
\text { nych przypadkach. }\end{array}$ & $\begin{array}{l}\text { Umiejętności w zakresie przedsiębiorczości opierają } \\
\text { się na kreatywności - obejmującej wyobraźnię, myśle- } \\
\text { nie strategiczne i rozwiązywanie problemów - oraz na } \\
\text { krytycznej i konstruktywnej refleksji w ramach ewolu- } \\
\text { ujących procesów twórczych i na innowacji. Obej- } \\
\text { mują one zdolność pracy samodzielnej i zespołowej, } \\
\text { mobilizowania zasobów (ludzi i przedmiotów) oraz } \\
\text { prowadzenia działalności gospodarczej. Uwzględnia } \\
\text { to również zdolność podejmowania decyzji finanso- } \\
\text { wych związanych z kosztem i wartością. Kluczowe } \\
\text { znaczenie ma zdolność skutecznego komunikowania } \\
\text { się i negocjowania z innymi osobami, a także radzenia } \\
\text { sobie z niepewnością, dwuznacznością i ryzykiem } \\
\text { jako elementami procesu podejmowania świado- } \\
\text { mych decyzji. }\end{array}$ \\
\hline $\begin{array}{l}\text { Postawa przedsiębiorcza charakteryzuje } \\
\text { się inicjatywnością, aktywnością, nie- } \\
\text { zależnością i innowacyjnością zarówno } \\
\text { w życiu osobistym i społecznym, jak } \\
\text { i w pracy. Obejmuje również motywację } \\
\text { i determinację w kierunku realizowania } \\
\text { celów, czy to osobistych, czy wspólnych, } \\
\text { zarówno prywatnych jak i w pracy }\end{array}$ & $\begin{array}{l}\text { Postawa przedsiębiorcza charakteryzuje się zmysłem } \\
\text { inicjatywy i poczuciem sprawczości, proaktywnością, } \\
\text { otwartością na przyszłość, odwagą i wytrwałością } \\
\text { w dążeniu do celów. Obejmuje pragnienie motywowa- } \\
\text { nia innych osób i doceniania ich pomysłów, odczu- } \\
\text { wanie empatii i troskę o innych ludzi i świat, a także } \\
\text { przyjmowanie odpowiedzialności i postaw etycznych } \\
\text { w całym procesie. }\end{array}$ \\
\hline
\end{tabular}

Źródło: Opracowanie własne na podstawie Zalecenie... (2006) i Zalecenie... (2018). 
Warto podkreślić, że wszystkie kompetencje kluczowe uznaje się za jednakowo ważne, ponieważ każda z nich może przyczynić się do udanego życia w społeczeństwie wiedzy, zakresy wielu spośród tych kompetencji częściowo się pokrywają i są powiązane, aspekty niezbędne w jednej dziedzinie wspierają kompetencję w innej (Zalecenie... 2006). Oznacza to, że nie ma tutaj żadnej gradacji czy hierarchii kompetencji, a przedsiębiorczość traktuje się jako kompetencję równie ważną jak kompetencje językowe, cyfrowe czy matematyczne.

Należy także zauważyć, że ten duch myślenia o przedsiębiorczości jako kompetencji jest powszechnie przyjmowany przez innych autorów, często piszących niezależnie, bez odwołania się do koncepcji kompetencji kluczowych. Przykładowo we wcześniejszych pracach T. Rachwała $(2005,2006)$ podejmujących problematykę definicji przedsiębiorczości i cech osoby przedsiębiorczej oraz w słowniku szkolnym do podstaw przedsiębiorczości (Rachwał 2004) zauważyć można podobne podejście, choć na etapie ich tworzenia koncepcja kompetencji kluczowych nie była upowszechniona (pierwsze zalecenie opublikowano pod koniec 2006 r.). Wiele elementów, w tym także takich nieoczywistych jak zdolność do empatii czy postępowanie etyczne, jest wspólnych, co świadczy o podobnym myśleniu o kompetencjach przedsiębiorczych różnych specjalistów z niezależnych od siebie ośrodków badawczych. Podobnie twórcy nowej podstawy programowej do podstaw przedsiębiorczości, pracując niezależnie od zespołu roboczego Komisji Europejskiej, jeszcze przed ogłoszeniem nowego ujęcia w formie Zalecenia Rady UE (2018), zdecydowali się na wprowadzenie elementów, które pojawiły się później w nowej europejskiej definicji. Przejawem tego jest oparcie jej na założeniu, że podstawą kształtowania kompetencji przedsiębiorczych uczniów jest rozumienie procesów gospodarczych i świata finansów, a więc wiedza ekonomiczna i finansowa. Treści te stanowią dwa pierwsze działy nowej podstawy programowej (Rachwał i in. 2018). Wyakcentowano w niej także m.in. proaktywność, innowacyjność, podejmowanie świadomych decyzji, przyjmowanie postaw etycznych i społecznej odpowiedzialności, co zostało uwypuklone w nowej deskrypcji przedsiębiorczości jako kompetencji kluczowej. Należy więc uznać, że nowa podstawa programowa, choć powstała przed ogłoszeniem nowego zalecenia w sprawie kompetencji kluczowych, jest w pełni zgodna z europejską definicją przedsiębiorczości. Można więc mówić o pełnej, przynajmniej formalnej, implementacji zalecenia (2018) w polskim sys- 
temie edukacji. Dużo jednak w procesie jego wdrażania zależy od kompetentnych nauczycieli, nie tylko podstaw przedsiębiorczości, ale także innych przedmiotów. Ich wpływ na proces kształtowania kompetencji przedsiębiorczych ucznia - obok niego samego - jest decydujący. Nawet najlepsze zapisy europejskiej definicji przedsiębiorczości czy podstawy programowej nie spełnią swojej roli, jeśli nie będzie chęci do ich poznania i implementacji w praktyce szkolnej. Wiele też zależy od przedsiębiorczości samych nauczycieli. Pozytywny sygnał w tym zakresie wynika z badań ankietowych M. Borgiasz (2017), które wykazały przekonanie nauczycieli o tym, że kształtowanie młodego człowieka może odbywać się tylko przez przyjmowanie przez nich postaw przedsiębiorczych oraz dosyć wysoką samoocenę nauczycieli wielu kompetencji własnych w zakresie przedsiębiorczości.

\section{Podsumowanie i wnioski końcowe}

Należy stwierdzić, że mimo niejednoznaczności i wieloznaczności pojęcia przedsiębiorczości i wielu różnych perspektyw badawczych i ujęć tego zjawiska, istnieje dosyć powszechna zgoda, przynajmniej w krajach europejskich, co do jej definiowania na potrzeby systemu edukacji. Pewną bazę stanowi definicja przedsiębiorczości jako kompetencji kluczowej, która choć niedoskonała, ewoluuje w dobrym kierunku, o czym świadczy jej nowa deskrypcja z 2018 r. Ponadto duch podobnego myślenia o tym, czy powinna być przedsiębiorczość na potrzeby edukacyjne, najpierw określana w Polsce jako zestaw cech osobowości i postawa człowieka, a później jako zestaw kompetencji, widoczny jest w pracach innych autorów. Do europejskiej definicji mocno nawiązali badacze realizujący projekt EntreComp, którego zadaniem było stworzenie modelu koncepcyjnego przedsiębiorczości jako kompetencji oraz zapisy polskiej podstawy programowej do podstaw przedsiębiorczości dla szkół średnich. Pozostaje więc mieć nadzieję, że Polska będzie nadal przykładem europejskiego lidera we wdrażaniu tych, w tym wypadku niezaprzeczalnie bardzo dobrych zaleceń rozwiązań w systemie edukacji. Mocna pozycja podstaw przedsiębiorczości jako obowiązkowego przedmiotu kształcenia ogólnego w szkole średniej, obecność elementów edukacji w zakresie przedsiębiorczości na niższych poziomach edukacji, już od przedszkola² daje podstawy 
do pozytywnego myślenia o efektach kształtowania kompetencji przedsiębiorczych polskich uczniów.

Należy zdawać sobie oczywiście sprawę, że część kompetencji przedsiębiorczych jak wytrwałość, proaktywność, zapał do pracy, pewność siebie czy odpowiedzialność jest trudna do wyuczenia w toku edukacji szkolnej. Raczej można mówić tutaj o procesie uczenia się czy stawania się przedsiębiorczym. Dlatego konieczne jest odpowiednie podejście nauczycieli do uczniów, przede wszystkich stosowanie odpowiednich metod nauczania, z reguły innych niż tradycyjne, wykorzystywane w przypadku zajęć z innych przedmiotów. Bardziej tutaj chodzi przecież o inspirowanie uczniów do rozwijania w sobie tych kompetencji niż przekazywanie wiedzy jak być przedsiębiorczym. Ważna jest też świadomość kształtowania kompetencji przedsiębiorczych w ramach wszystkich przedmiotów szkolnych. W polskim systemie edukacji mamy jednak rzeszę dobrze wykształconych nauczycieli, którzy są w stanie sprostać temu zadaniu. Powinno to być jednak otoczone troską ze strony państwa, czego przejawem - oprócz wysokiej jakości kształcenia nowej kadry pedagogicznej - powinien być także rozwój zawodowy poprzez kursy i studia doskonalące. Wydają się one szczególnie ważne w przypadku nauczycieli przedmiotów innych niż podstawy przedsiębiorczości, aby mieli świadomość potrzeby i umiejętność rozwijania kompetencji przedsiębiorczych uczniów w ramach różnych przedmiotów, lekcji wychowawczych i innych zajęć w szkole. 


\section{Bibliografia}

$\rightarrow$ Bacigalupo, M., Kampylis, P., Punie, Y., Van den Brande, G. (2016), EntreComp: The Entrepreneurship Competence Framework. Luxembourg: Publication Office of the European Union.

$\rightarrow$ Białasiewicz, M. (2008), Przedsiębiorczość - pożq̨dana kompetencja [w:] „Studia i Prace Wydziału Nauk Ekonomicznych i Zarządzania Uniwersytetu Szczecińskiego", nr 1, s. 7-16.

$\rightarrow$ Borgiasz, M. (2017), Kompetencje przedsiębiorcze - ich rola i znaczenie w pracy współczesnego nauczyciela [w:] „Szkoła - Zawód - Praca”, z. 14, s. 185-201.

$\rightarrow$ Borowiec, M., Rachwał, T. (2011), Kształtowanie postaw przedsiębiorczych na lekcjach geografii wyzwaniem edukacyjnym w procesach globalizacji [w:] „Przedsiębiorczość - Edukacja”, nr 7, s. 321-332.

$\rightarrow$ Brzozowski, T. (2007), „Przedsiębiorczość” - pojęcie polisemiczne czy niewłaściwie rozumiane? Próba systematyzacji [w:] „Przedsiębiorczość - Edukacja”, nr 3, s. 196-203.

$\rightarrow$ Carlebach, E. (2016), Teach us to be the authors of our own lives [w:] "Live \& Learn", nr 37, s. 7-9.

$\rightarrow$ Cieślik, J. (2014), Przedsiębiorczość, polityka, rozwój, Warszawa: Wydawnictwo Akademickie Sedno.

$\rightarrow$ Cieślik, J. (2015), Miejsce przedsiębiorczości w strukturze nauk o zarzq̨dzaniu [w:] „Kwartalnik Nauk o Przedsiębiorstwie”, nr 2, s. 59-69.

$\rightarrow$ Gaweł, A. (2013), Proces przedsiębiorczy. Tworzenie nowych przedsiębiorstw, Warszawa: Difin.

$\rightarrow$ Glinka, B., Gudkova, S. (2011), Przedsiębiorczość, Warszawa: Oficyna Wolters Kluwer business.

$\rightarrow$ Godlewska-Majkowska, H. (2011), Atrakcyjność inwestycyjna polskich regionów i przedsiębiorczość regionalna - ujęcie kompleksowe [w:] „Atrakcyjność inwestycyjna a przedsiębiorczość regionalna w Polsce", Studia i Analizy Instytutu Przedsiębiorstwa, s. 25-47. 
$\rightarrow$ Kompetencje kluczowe. Realizacja koncepcji na poziomie szkolnictwa obowiq̨zkowego, 2005, Warszawa: Eurydice, Fundacja Rozwoju Systemu Edukacji.

$\rightarrow$ Korpysa, J. (2013), Kompetencje przedsiębiorcze właścicieli MSP [w:] „Przedsiębiorczość i Zarządzanie", nr 14, z. 3, s. 169-178.

$\rightarrow$ Kraśnicka, T. (2001), Przedsiębiorczość jako przedmiot badań ekonomistów [w:] Ekonomia, nr 4, s. 187-200.

$\rightarrow$ Kwiatkowski, S.M. (2018), Kompetencje przyszłości [w:] S.M. Kwiatkowski (red.), Kompetencje przyszłości, Warszawa: Fundacja Rozwoju Systemu Edukacji, s.14-29 .

$\rightarrow$ Mitchelmore, S., Rowley, J. (2010), Entrepreneurial competencies: a literature review and development agenda. International [w:] „Journal of Entrepreneurial Behaviour \& Research", nr 16(2), s. 92-111.

$\rightarrow$ Pilewicz, T. (2012), Region jako organizacja przedsiębiorcza w zarządzaniu strategicznym, [w:] „Kwartalnik Nauk o Przedsiębiorstwie”, nr 3, s. 27-35.

$\rightarrow$ Piróg, D. (2013), Absolwenci szkół wyższych na rynku pracy w warunkach kryzysu [w:] „Przedsiębiorczość - Edukacja”, nr 9, s. 302-316.

$\rightarrow$ Piróg, D. (2014), Uwarunkowania przedsiębiorczości absolwentów szkół wyższych: założenia teoretyczne i stan rzeczywisty [w:] „Przedsiębiorczość - Edukacja", nr 10, s. 306-315.

$\rightarrow$ Piróg, D. (2015), Kompetencje z zakresu przedsiębiorczości: rozważania teoretyczne i ich ilustracje w obszarze szkolnictwa wyższego [w:] „Przedsiębiorczość - Edukacja", nr 11, s. 364-376.

$\rightarrow$ Piróg, D. (2016), Wybrane determinanty przedsiębiorczości indywidualnej-zarys stanu badań [w:] „Przedsiębiorczość - Edukacja”, nr 12, s. 300-314.

$\rightarrow$ Płaziak, M., Rachwał, T. (2015), "Przedsiębiorczy region” - zarys koncepcji w świetle analizy roli przedsiębiorczości w krajowej strategii rozwoju regionalnego [w:] „Przedsiębiorczość - Edukacja”, nr 11, s. 37-49.

$\rightarrow$ Rachwał, T. (2004), Podstawy przedsiębiorczości - słownik dla liceum ogólnokształcącego, liceum profilowanego i technikum, Warszawa: Wydawnictwo Nowa Era.

$\rightarrow$ Rachwał, T. (2005), Kształtowanie postaw uczniów na lekcjach podstaw przedsiębiorczości [w:] „Przedsiębiorczość-Edukacja”, nr 1, s.137-144.

$\rightarrow$ Rachwał, T. (2006), Kształtowanie postaw przedsiębiorczych w edukacji szkolnej [w:] Szkoła w nauce i praktyce edukacyjnej, t.II, B. Muchacka (red.), Kraków: Oficyna Wydawnicza „Impuls", Akademia Pedagogiczna w Krakowie, s.427-434.

$\rightarrow$ Rachwał, T. (2018), Research Issues of the Function of Entrepreneurship in the Socio-Economic Development of Spatial Systems in Polish Economic Geography [w:] „Prace Komisji Geografii Przemysłu Polskiego Towarzystwa Geo- 
graficznego" ["Studies of the Industrial Geography Commission of the Polish Geographical Society"], nr 32(4), s. 149-162.

$\rightarrow$ Rachwał, T., Kilar, W., Kawecki, Z., Wróbel, P. (2018), Edukacja w zakresie przedsiębiorczości w wychowaniu przedszkolnym, szkole podstawowej i szkołach średnich w świetle nowej podstawy programowej [w:] „Przedsiębiorczość - Edukacja", nr 14, s. 389-424.

$\rightarrow$ Rachwał, T., Kurek, S., Boguś, M. (2016), Entrepreneurship Education at Secondary Level in Transition Economies: A Case of Poland [w:] "Entrepreneurial Business and Economics Review", nr 4(1), s. 61-81.

$\rightarrow$ Słownik języka polskiego, 2005, Warszawa: Wydawnictwo PWN.

$\rightarrow$ Szkurłat, E., Hibszer, A., Piotrowska, I., Rachwał, T. (2018) Podstawa programowa geografii źródłem nauczycielskich wyzwań [w:] A. Hibszer, E. Szkurłat (red.), Nauczyciel geografii wobec wyzwań reformowanej szkoły, Seria: Prace Komisji Edukacji Geograficznej Polskiego Towarzystwa Geograficznego, t. 8, Sosnowiec: Komisja Edukacji Geograficznej PTG, s. 13-31.

$\rightarrow$ Szromnik, A. (2012), Miasto przedsiębiorcze $i$ innowacyjne w regionie [w:] "Zeszyty Naukowe Uniwersytetu Szczecińskiego. Ekonomiczne Problemy Usług", nr 98, Przedsiębiorczość szansą rozwoju regionu. T. 2, Kształtowanie przedsiębiorczości, s. 323-346.

$\rightarrow$ Tracz, M. (2006), Rola i znaczenie "podstaw przedsiębiorczości" w kształceniu ogólnym [w:] „Przedsiębiorczość - Edukacja”, nr 2, s. 222-225.

$\rightarrow$ Wach, K. (2015), Przedsiębiorczość jako czynnik rozwoju społeczno-gospodarczego: przegląd literatury [w:] „Przedsiębiorczość-Edukacja” , nr 11, s. 24-36.

$\rightarrow$ Wach, K. (2014a), Edytorial: Przedsiębiorczy uniwersytet [w:] „Horyzonty Wychowania", nr 13(28), s. 3-6.

$\rightarrow$ Wach, K. (2014b), Paradygmat gospodarki przedsiębiorczej a polityka wspierania przedsiębiorczości (rozdział 1) [w:] K. Zieliński (red.), Formy i przejawy współczesnej przedsiębiorczości w Polsce, Warszawa: Difin, s. 13-30.

$\rightarrow$ Wach, K. (2014c), Edukacja dla przedsiębiorczości: pomiędzy przedsiębiorczq pedagogikq a edukacjq ekonomicznq i biznesowa [w:] "Horyzonty Wychowania", nr 13(28), s. 11-31.

$\rightarrow$ Zalecenie Parlamentu Europejskiego i Rady z dnia 18 grudnia 2006 r. w sprawie kompetencji kluczowych w procesie uczenia się przez całe życie (2006/962/WE).

$\rightarrow$ Zalecenie Rady z dnia 22 maja 2018 r. w sprawie kompetencji kluczowych w procesie uczenia się przez całe życie (Tekst mający znaczenie dla EOG), Dz. UE 2018/C 189/01.

$\rightarrow$ Zioło, Z. (2016). Zarys uwarunkowań kształtowania przedsiębiorczego uniwersytetu [w:] „Horyzonty Wychowania”, nr 15(35), s. 29-54. 
$\rightarrow$ Zioło, Z. (2012), Miejsce przedsiębiorczości w edukacji [w:] „Przedsiębiorczość - Edukacja", nr 8, s. 10-23.

$\rightarrow$ Zioło, Z., Rachwał, T. (2012), Entrepreneurship in geographical research [w:] P. Churski (red.), "Contemporary Issues in Polish Geography", Poznań: Bogucki Wydawnictwo Naukowe, s. 135-155. 


\title{
Geneza i ewolucja pojęcia przedsiębiorczości
}

\author{
Piotr Komraus
}

W rozdziale przedstawiony został proces ewolucji pojęć przedsiębiorcy i przedsiębiorczości w myśli ekonomicznej. Wskazane zostały podstawowe nurty w sposobie postrzegania roli i znaczenia przedsiębiorczości dla wzrostu oraz rozwoju gospodarczego. W oparciu o wskazane kryteria wyróżniono pięć głównych podejść w definiowaniu analizowanych pojęć. Scharakteryzowany został dorobek wybranych ekonomistów reprezentujących poszczególne podejścia. Podjęta została także próba określenia kierunku ewolucji przedsiębiorczości w przyszłości.

\section{Słowa kluczowe:}

\section{przedsiębiorczość}

przedsiębiorca

historia myśli ekonomicznej

rozwój gospodarczy 


\title{
The genesis and evolution of the notion of entrepreneurship
}

\author{
Piotr Komraus
}

This chapter presents the process of evolution of the notions of an entrepreneur and entrepreneurship in economic thought. Two basic trends in the way of perceiving the role and significance of entrepreneurship for the economic growth and development have been depicted. On the basis of the indicated criteria five main attitudes towards defining the analyzed notions have been differentiated. The output of some selected economists representing particular attitudes has been presented. The attempt to determine the direction of the evolution of entrepreneurship in the future has also been made.

\section{Keywords:}

entrepreneurship

entrepreneur

history of economic thought 


\section{Wstęp}

W okresie przed rewolucją przemysłową przedsiębiorczość stanowiła cechę człowieka wyrażającą się działalnością ukierunkowaną na zaspokajanie potrzeb. Naturalne poczucie braku czegoś wymuszało podejmowanie zróżnicowanych form aktywności na rzecz jego zaspokojenia. Nowy wymiar pojęcia przedsiębiorczości pozostaje ściśle związany z rewolucją przemysłową i przekształceniami procesów gospodarowania oraz procesów społecznych. Pojęcie podlega ewolucji w ramach powstających nurtów myśli ekonomicznej. Rozpatrywane jest także w ujęciu psychologicznym, socjologicznym, antropologicznym i kulturowym.

Wskazania wymaga podstawowa różnica w definiowaniu przedsiębiorczości przez ekonomię i pozostałe nauki społeczne. W podejściu ekonomicznym przedsiębiorczość i przedsiębiorcę określa rola pełniona w mechanizmie gospodarczym. Ujęcie psychologiczne, społeczne, kulturowe postrzega przedsiębiorczość jako zespół postaw (o komponentach: emocjonalnym - nastroje i uczucia, behawioralnym - predyspozycje do zachowań i poznawczym) oraz zachowań (intencje, sposobność prowadzenia aktywności gospodarczej ${ }^{1}$ ) jednostki i społeczeństwa wpływających na kształtowanie własnej przyszłości (Białasiewicz 2008, s. 9).

\section{Przedsiębiorczość w teorii ekonomii - rys historyczny}

Teorię ekonomii charakteryzuje zróżnicowane podejście w ocenie znaczenia przedsiębiorczości dla rozwoju społeczno-gospodarczego. Podstawowym podziałem - w przedmiotowym zakresie - myśli ekonomicznej jest podział na nurt wskazujący przedsiębiorczość jako czynnik rozwoju gospodarczego oraz nurt zagadnienie pomijający. Pierwszy z wyszczególnionych nurtów tworzą m.in. R. Cantillon, fizjokraci z F. Quesnayem, A. Smith, J.B. Say, szkoła schumpeterowska, szkoła austriacka oraz w ramach szkoły chicagowskiej-F. Knight. Ograniczoną rolę w pobudzaniu rozwoju społeczno-gospodarczego przedsiębiorczości przypisuje keynesizm. Zagadnienie przedsiębiorczości pozostaje natomiast niedostrzegane przez:

1. Psychologiczne aspekty przedsiębiorczości, „Forum Współpracy Małego i Dużego Biznesu”, forumbiznesu-zpp.pl/aktualnosci/psychologiczne-aspekty-przedsiebiorczosci (dostęp 30.11.2018). 
$\rightarrow$ ekonomię klasyczną i neoklasyczną (wyjątkami wśród ekonomistów klasycznych są A. Smith i J.B. Say oraz w zakresie ekonomii neoklasycznej - szkoła austriacka),

$\rightarrow$ marksizm uznający klasę robotniczą za podstawową siłę zmian i postrzegający rozwój jako wynik zarówno determinizmu, jak i dialektyki.

Przeprowadzone studia literaturowe pozwoliły na wyodrębnienie w ramach nurtu afirmującego rolę przedsiębiorczości pięciu kryteriów definiujących pojęcia przedsiębiorcy i przedsiębiorczości. Kryteriami powyższymi są: niepewność, pełniona funkcja dostawcy kapitału, zorientowanie na zysk, umiejętność tworzenia i forma zarządzania organizacją oraz innowacyjność. Proces wskazywania kryteriów wyraża ewolucję pojęcia przedsiębiorczości w myśli ekonomicznej.

Podejście definiujące przedsiębiorczość jako funkcję niepewności zainicjowane zostało na początku XVIII w. przez R. Cantillona. Rozwinięcie podejścia zawierają prace m.in. J.B. Saya, H.K. von Mangoldta, L. von Misesa oraz F. Knighta. Wkładem R. Cantillona w myśl ekonomiczną jest wyróżnienie i analiza pojęcia przedsiębiorcy (Rothbard 2011) oraz jego roli i znaczenia w gospodarce. W pracy Essay on the nature of trade in general R. Cantillon (1959) przedstawia szczegółową analizę procesów rynkowych w aspekcie problemu równowagi rynkowej i wszechobecnej niepewności, wskazuje pożądane zachowania podmiotów uczestniczących w procesach rynkowych, analizuje różnice wartości wykonywanej pracy, poszukuje uzasadnienia dla istnienia przedsiębiorców, jak również wskazuje ich funkcje w mechanizmie rynkowym. Kryterium wyróżniającym przedsiębiorców jest kryterium niepewności uzyskiwanych dochodów. Podejście to wywierało istotny wpływ na definiowanie przedsiębiorcy do lat 20. XX w. i prac F. Knighta (Hebert, Link 2011). Społeczeństwo dzieli on na przedsiębiorców oraz ludzi zatrudnionych. Zatrudnieni, bez względu na charakter wykonywanej pracy, stanowią grupę o ograniczonej, w okresie zatrudnienia, niepewności i określonych dochodach. Przedsiębiorców charakteryzuje szeroko postrzegana niepewność, w tym niepewność uzyskiwanych dochodów. Pojęcie przedsiębiorcy jest traktowane bardzo szeroko i $w$ istocie obejmuje każdego, kto podejmuje aktywność gospodarczą w warunkach niepewności ( $w$ tym także żebraków). Bogactwo wszystkich mieszkańców pochodzi z własności posiadaczy ziemskich i wszyscy są od nich zależni 
(Cantillon 1959). „Zadaniem biznesmena i przedsiębiorcy jest stanąć naprzeciw i sprostać niepewności poprzez inwestowanie i opłacanie kosztów z nadzieją na zysk². Sklepikarze i kupcy detaliczni wszelkich rzeczy są przedsiębiorcami, którzy kupują rzeczy po określonej cenie i sprzedają w swoich sklepach lub na rynkach po cenie niepewnej. Tym, co zachęca i utrzymuje przedsiębiorców w danym państwie, są konsumenci, którzy będąc ich klientami, wolą płacić nieco więcej, aby otrzymywać to, czego potrzebują do użycia w małych ilościach, w porównaniu z tym, co jest w magazynach, i większość z nich nie ma wystarczających środków, aby kupować z pierwszej ręki" (Cantillon 1959). Przedsiębiorcy pełnią funkcję równoważącą. Poprzez przewidywanie i inwestowanie zasobów na przyszłość przedsiębiorcy pomagają dopasować oraz zbalansować dostawy i popyt (Rothbard 2011).

Przedsiębiorcę w podejściu J.B. Saya wyróżniają zaangażowanie w proces produkcyjny oraz niepewność co do efektu podejmowanych działań. Przedsiębiorcy prowadzą działalność we wszystkich gałęziach gospodarki. Przedsiębiorcami są: rolnicy, rękodzielnicy, kupcy. Przedsiębiorca "współdziała w produkcji, oddając na jej usługi wiedzę, kapitały, umiejętne wykorzystanie czynników naturalnych w celu wytwarzania produktów, do których ludzie przywiązują wartość". Podstawowym wyzwaniem dla przedsiębiorcy jest wytworzenie produktów wartych "przynajmniej tyle lub więcej co koszty produkcji". J.B. Say dokonuje wyraźnego rozróżnienia pomiędzy przedsiębiorcą a kapitalistą. Przedsiębiorca nie musi być kapitalistą. „Przedsiębiorcy są kapitalistami tylko wtedy, kiedy zaangażowany kapitał lub jego część stanowią ich własność" (Say 1960, s. 890). Kapitalista jest posiadaczem kapitału i czerpie z niego zyski, wykorzystując go we własnej pracy lub uzyskując od niego procent (Say 1960, s. 869).

H.K. von Mangoldt tytuł przedsiębiorcy przypisuje podmiotowi posiadającemu prawo do efektów produkcji i kontroli produktu, a jednocześnie ponoszącemu odpowiedzialność za wszelkie straty. Odrzuca podejście definiujące przedsiębiorcę jako osobę angażującą się i nadzorującą proces produkcji, wskazując, że czynności te mogą być efektywnie wypełniane także przez płatną siłę roboczą. Ryzyko przedsiębiorcy wyznacza charakter realizowanej produkcji. Wysokim ryzykiem 
obciążona jest produkcja na rynek. Za bezpieczną uznaje produkcję na zamówienie, w której wyeliminowany zostaje czynnik ryzyka (Hebert, Link 2011). L. von Mises zrównuje pojęcie przedsiębiorczości i spekulacji. Niepewność jest cechą każdego ludzkiego działania i każde działanie jest formą spekulacji. W konsekwencji wszyscy ludzie (także pracownicy), pragnąc wykorzystywać swoje zasoby i umiejętności w celu osiągnięcia zysku, są przedsiębiorcami (Butler 2010). F. Knight w książce Risk, Uncertainty and Profit wskazuje, że w warunkach braku niepewności energia człowieka byłaby w całości poświęcona produkcji. Wątpliwe jest, czy w takiej sytuacji istniałaby inteligencja. W warunkach niepewności produkcja rzeczy, faktyczne wykonywanie czynności, staje się zadaniem wtórnym. Głównym problemem i funkcją organizacji jest wskazywanie, co należy zrobić i jak to zrobić (Knight 1964).

Reprezentantem podejścia definiującego przedsiębiorczość zgodnie z kryterium zorientowania na zysk jest J.M. Keynes. Keynesizm jako nurt w myśli ekonomicznej wyraża ograniczone zainteresowanie problematyką przedsiębiorczości, będące następstwem wielkiego kryzysu, podważonego zaufania do systemu kapitalistycznego i poszukiwania możliwości oraz narzędzi przeciwdziałania kryzysom. Istotę keynesizmu wyraża "teza o możliwości istnienia bezkryzysowego kapitalizmu, kierowanego przez państwo w interesie całego społeczeństwa ku ogólnemu dobrobytowi" (Keynes 2003, s. IX). Dominująca rola państwa w kształtowaniu wzrostu i rozwoju gospodarczego spycha znaczenie przedsiębiorczości na dalszy plan. „Schorzenia kapitalizmu są możliwe do wyleczenia tylko przez zastosowanie środków, które albo są dla społeczeństwa nie do przyjęcia (zbrojenia, wojna), albo wymagają ograniczenia wszechwładzy kapitału" (Keynes 2003, s. IX). Przedsiębiorczość przez J.M. Keynesa definiowana jest jako działalność polegająca "na określaniu przewidywanego dochodu z obiektów kapitałowych w ciągu całego ich trwania" (Keynes 2003, s. 139). Przewidywanie psychiki rynku (ocenę niepewności) nazywa spekulacją. Jak wskazuje, przedsiębiorczość jest następstwem drzemiących w człowieku zwierzęcych instynktów, a przedsiębiorcy jedynie udają, że kierują nimi skrupulatne analizy. Przedsiębiorczość jest korzystna dla społeczeństwa jedynie w sytuacjach, gdy kalkulacje uzupełnia zwierzęcy instynkt. Pozwala on odsunąć myśli o porażce. Podstawowym czynnikiem determinującym ożywienie gospodarcze jest atmosfera polityczno-społeczna, w której funkcjonuje przeciętny przedsiębiorca (Keynes 2003). 
Współcześnie uznanym kryterium identyfikacji przedsiębiorcy i przedsiębiorczości jest innowacyjność. Podejście to zainicjowane zostało teorią przedsiębiorczości J. Schumpetera i następnie rozwinięte przez liczne grono ekonomistów. Czynnikiem konstytuującym przedsiębiorcę $w$ teorii J. Schumpetera jest realizowanie nowych kombinacji czynników produkcji i w konsekwencji tworzenie nowej wiedzy. Funkcja ta musi zawsze współistnieć z pozostałymi rodzajami działalności realizowanej przez podmiot gospodarczy. Przedsiębiorca schumpeterowski jest przedsiębiorcą jedynie w okresie tworzenia nowej wiedzy (Schumpeter 1960). Schumpeterowska teoria przedsiębiorczości spowodowała zmianę zarówno w sposobie tworzenia wiedzy, jak i stawianych wobec niej oczekiwań. Nowa wiedza przez przedsiębiorcę tworzona jest we współpracy z ośrodkami naukowo-badawczymi, od których oczekuje się „produkcji wiedzy”. Tradycyjny system badań naukowych stał się niewydolny i został zastąpiony aplikacyjnym modelem wytwarzania wiedzy. Produkowana wiedza jest wynikiem ścierania się potrzeb, interesów i specyfikacji zaangażowanych podmiotów (Pohulak-Żołędowska 2013). Badania prowadzone są wyłącznie nad tym, co może podlegać komercjalizacji. Zamierają niekomercyjne dziedziny nauki. Retoryczne pozostają pytanie: $W$ jakim zakresie obserwowane procesy prowadzą do zniszczenia nauki podporządkowanej interesom przemysłu oraz czy "produkowana wiedza” jest wiedzą w jej filozoficznym rozumieniu wskazywanym przez Platona i Arystotelesa? Zwrócenia uwagi wymaga sytuacja, w której na znaczenie sektora nauki dla rozwoju gospodarczego oraz zgodny z porządkiem naturalnym proces powstawania i wykorzystywania wiedzy wskazywał już J.B. Say. „Uczeni uczestniczą w produkcji, oddając na jej usługi wiedzę o prawach i ciałach przyrody, które następnie przedsiębiorcy przemysłowi wykorzystują na użytek człowieka" (Say 1960, s. 894).

Koncepcją współistniejącą z podejściem schumpeterowskim jest koncepcja identyfikacji przedsiębiorczości według kryterium umiejętności i sposobu zarządzania organizacją, przedstawiona w pracach W. Gartnera i H. Stevensona. W. Gartner przedsiębiorczość definiuje jako proces tworzenia organizacji. W definiowaniu przedsiębiorcy wyróżnia podejście behawioralne oraz zorientowane na cechy. $W$ podejściu behawioralnym wskazuje konieczność analizowania przedmiotu działalności przedsiębiorcy. Przedsiębiorcą jest ten, kto tworzy organizację. W podejściu zorientowanym na cechy przedsiębiorca jest szczególnym 
typem osobowości, stałym stanem bytu. W odróżnieniu od podejścia schumpeterowskiego przedsiębiorca W. Gartnera jest przedsiębiorcą na zawsze (Gartner 1989). H. Stevenson dokonuje rozróżnienia pomiędzy zachowaniami przedsiębiorczymi i zarządzaniem. Przedsiębiorczość definiuje jako podejście do zarządzania, w którym poszukuje się i wykorzystuje szanse niezależnie od kontrolowanych zasobów. Celem zarządzającego jest najefektywniejsze wykorzystanie posiadanych zasobów. Zachowania determinują czynniki biznesowe i środowiskowe. Działania przedsiębiorcy napędzają możliwości istniejące w otoczeniu. Każda szansa jest istotna. Dla zarządzającego istotne są wyłącznie szanse odnoszące się do posiadanych zasobów. Przedsiębiorca jest zorientowany na działanie. Równie szybko angażuje się w działanie, jak i z niego się wycofuje. Zarządzający mają skłonność do podejścia analitycznego. Podejmowane przez nich decyzje są wynikiem analizy wielokryterialnej, wynegocjowanych strategii i działań minimalizujących ryzyko (Brown, Davidsson, Wiklund 2001).

\section{Przedsiębiorczość przyszłości}

Ewolucja pojęcia oraz wskazywanej roli przedsiębiorczości w rozwoju społeczno-gospodarczym będzie także następowała w przyszłości. Proces globalizacji stał się zalążkiem nowej formy przedsiębiorczości nazwanej przedsiębiorczością międzynarodową. Forma ta odegra kluczową rolę w kształtowaniu globalnego ładu społeczno-gospodarczego. Analiza postaw globalnych przedsiębiorstw pozwala twierdzić, że kolejnym etapem ewolucji przedsiębiorczości będzie przejmowanie przez przedsiębiorców tradycyjnych funkcji państwa i Kościoła. Należy oczekiwać ze strony przedsiębiorstw globalnych roszczenia sobie prawa do określania zasad życia społecznego, kształtowania systemu wartości, definiowania pojęć dobra i zła czy wprowadzania globalnej kontroli zgodności zachowań jednostki z systemami wartości organizacji. Niewątpliwie przejmowanie przez globalnych przedsiębiorców kontroli nad kolejnymi sferami życia może skutkować zniszczeniem wolnego rynku, konkurencji i w konsekwencji upadkiem kapitalizmu.

Uzasadnieniem dla powyższego twierdzenia jest analiza aktualnie podejmowanych działań przez firmy takie jak Facebook, Google, YouTube, Twitter w zakresie cenzurowania dopuszczanych do rozpowszechniania za ich pośrednictwem treści. Cenzurowaniu podlegają treści nienaruszające obowiązującego prawa, lecz jedynie kontestujące zachodzące 
procesy społeczne, polityczne i gospodarcze. Szczególną uwagę zwraca wystąpienie T. Cooka, dyrektora zarządzającego Apple Inc., który stwierdził: „W Apple nie boimy się mówić, że nasze wartości kierują naszymi decyzjami o wyborze działania. Wierzę, że najświętszą rzeczą, którą każdy z nas otrzymuje, jest nasz osąd, nasza moralność, nasze własne wrodzone pragnienie oddzielenia dobra od zła. Wybór odłożenia odpowiedzialności w momencie próby jest grzechem" ${ }^{3}$. W wypowiedzi tej jednoznacznie odrzucone zostaje wynikające z prawa naturalnego pojęcie dobra i zła na rzecz systemu wartości, którym kieruje się organizacja. Organizacja w sposób bezwzględny podejmuje próby narzucenia własnego systemu wartości globalnej populacji. Odrzucając zarazem - w ramach prowadzonej walki z wszelkimi formami dyskryminacji - wszelkie „inne” systemy wartości, w szczególności zaś system wartości oparty na Dekalogu.

Jednocześnie globalne przedsiębiorstwa tworzą narzędzia kontroli społeczeństw. Do współpracy nad systemem globalnej kontroli poprzez system uniwersalnej cyfrowej tożsamości przyznały się Microsoft oraz Mastercard ${ }^{4}$. Aktualnie osiem firm prowadzi badania nad systemami oceny wiarygodności obywateli. Systemy obejmują czarne listy, w ramach których gromadzone są informacje o niepożądanych i/lub niezgodnych z prawem zachowaniach poszczególnych obywateli, informacja finansowa oraz informacja o zachowaniach społecznych, w tym kontaktach z innymi ludźmi. Umieszczenie na czarnej liście skutkuje ograniczeniem lub wykluczeniem jednostki z życia społeczno-gospodarczego. O efektywności budowanych narzędzi kontroli społeczeństwa oraz zagrożeń z nich wynikających świadczy to, że system oceny wiarygodności obywateli działający w Chinach uniemożliwił osobom kontrolowanym odbycie 11,14 mln lotów samolotem oraz 4,25 $\mathrm{mln}$ przejazdów szybkimi pociągami ${ }^{5}$.

3. Tim Cook's message to hatemongers: 'You have no place on our platforms', www.cnbc.com/2018/12/04/apple-ceo-tim-cook-says-hate-has-no-place-on-techplatforms-at-adl.html; Apple's CEO Suggests It's 'A Sin' To Not Ban People From Platforms, www.dailywire.com/news/38991/watch-apples-ceo-suggests-its-sin-not-ban-people-ryansaavedra [dostęp 6.12.2018].

4. Mastercard, Microsoft Join Forces to Advance Digital Identity Innovations, newsroom.mastercard.com/press-releases/mastercard-microsoft-join-forces-to-advancedigital-identity-innovations [dostęp 6.12.2018].

5. System oceny obywateli w Chinach powstrzymał już ludzi od $11 \mathrm{mln}$ lotów i $4 \mathrm{mln}$ podróży pocig̨giem, businessinsider.com.pl/lifestyle/podroze/system-oceny-obywateli-w-chinachefekty-dzialania/7yl1phz [dostęp 1.12.2018]. 


\section{Podsumowanie i wnioski}

Pojęcia przedsiębiorcy i przedsiębiorczości ukształtowały się po rewolucji przemysłowej. Podlegały one ewolucji w następstwie powstawania kolejnych szkół myśli ekonomicznej. Zmianom podlegała także wskazywana przez naukę rola przedsiębiorczości w rozwoju społeczno-gospodarczym. Obserwowane procesy zachodzące w sferze realnej pozwalają twierdzić, że przedsiębiorczość będzie odgrywała także istotną rolę w przyszłości. Działania globalnych przedsiębiorstw mające na celu przejmowanie funkcji należnych państwom i Kościołowi wymagają nieustannego podejmowania przez władze publiczne działań na rzecz ograniczania aktywności przedsiębiorstw do sfery gospodarczej. 


\section{Bibliografia}

$\rightarrow$ Białasiewicz, M. (2008), Przedsiębiorczość - pożq̨dana kompetencja, "Studia i Prace Wydziału Nauk Ekonomicznych i Zarządzania", Uniwersytet Szczeciński, nr 1, s. 7-16.

$\rightarrow$ Brown, T., Davidsson, P., Wiklund, J. (2001), An Operationalization of Stevenson's Conceptualization of Entrepreneurship as Opportunity - based Firm Behavior, "Strategic Management Journal”, nr 22 (10), s. 953-968.

$\rightarrow$ Butler, E. (2010), Ludwig von Mises. Kompendium myśli ekonomicznej, Warszawa: Instytut Globalizacji.

$\rightarrow$ Cantillon, R. (1959), Essay on the nature of trade in general, London: Frank Cass and Co, www.econlib.org/library/NPDBooks/Cantillon/cntNT.html?chapter_num=9\#book-reader [dostęp 9.10.2018].

$\rightarrow$ Gartner, W.B. (1989), "Who is an Entrepreneur?" is the Wrong Question, "Entrepreneurship Theory and Practice", Vol. 13, Issue: 4, s. 47-68.

$\rightarrow$ Hebert, R.F., Link, A.N. (2011), A History of Entrepreneurship, Reviewed By K.V. Nagarajan, „International Journal of Business and Social Science”, Vol. 2, No 9 [Special Issue - May 2011].

$\rightarrow$ Keynes, J.M. (2003), Ogólna teoria zatrudnienia, procentu i pieniq̨dza, Warszawa: Wydawnictwo Naukowe PWN.

$\rightarrow$ Knight, F.H. (1964), Risk, uncertainty and profit, "Reprints of economic classic”, Augustus M. Kelley, Bookseller, New York 1964, mises.org/sites/default/files/ Risk,\%20Uncertainty,\%20and\%20Profit_4.pdf [dostęp 9.10.2018].

$\rightarrow$ Rothbard, M.N. (2011), Richard Cantillon - ojciec współczesnej ekonomii, mises. $\mathrm{pl} / \mathrm{blog} / 2011 / 02 / 02 /$ rothbard-richard-cantillon-ojciec-wspolczesnej-ekonomii [dostęp 9.10.2018].

$\rightarrow$ Say, J.B. (1960), Traktat o ekonomii politycznej, Warszawa: PWN.

$\rightarrow$ Schumpeter, J.A. (1960), Teoria rozwoju gospodarczego, Warszawa: PWN.

$\rightarrow$ Pohulak-Żołędowska, E. (2013), Miejsce nauki w kreowaniu innowacji we współczesnych gospodarkach, „Studia Ekonomiczne/Uniwersytet Ekonomiczny w Ka- 
towicach”, nr 139, „Współczesne problemy ekonomiczne: polityka państwa a proces globalizacji". 


\section{Netografia}

$\rightarrow$ Mastercard, Microsoft Join Forces to Advance Digital Identity Innovations, newsroom.mastercard.com/press-releases/mastercard-microsoft-join-forces-to-advance-digital-identity-innovations (dostęp: 6.12.2018).

$\rightarrow$ Psychologiczne aspekty przedsiębiorczości, Forum Współpracy Małego i Dużego Biznesu, forumbiznesu-zpp.pl/aktualnosci/psychologiczne-aspekty-przedsiebiorczosci (dostęp: 30.11.2018).

$\rightarrow$ System oceny obywateli w Chinach powstrzymał już ludzi od $11 \mathrm{mln}$ lotów i $4 \mathrm{mln}$ podróży pociągiem, businessinsider.com.pl/lifestyle/podroze/system-oceny-obywateli-w-chinach-efekty-dzialania/7yl1 phz (dostęp: 1.12.2018).

$\rightarrow$ Tim Cook's message to hatemongers: 'You have no place on our platforms', www.cnbc.com/2018/12/04/apple-ceo-tim-cook-says-hate-has-no-place-on-tech-platforms-at-adl.html; Apple's CEO Suggests It's 'A Sin' To Not Ban People From Platforms, www. dailywire.com/news/38991/watch-apples-ceo-suggests-its-sin-not-ban-people-ryan-saavedra (dostęp: 6.12.2018). 


\section{Przedsiębiorczość a innowacyjność \\ - rozumienie i delimitacja pojęć}

Piotr Kopyciński

Celem niniejszego rozdziału jest dokonanie delimitacji używanych czasami synonimicznie pojęć „przedsiębiorczość" oraz „innowacyjność". Dla zrealizowania tego zamierzenia wskazano na rozumienie tych sformułowań, a także wyrażeń pokrewnych („przedsiębiorca” $i$ „innowacja”). Wśród różnych ujęć przedsiębiorczości skoncentrowano się na tym mającym powiązanie z innowacyjnością.

\section{Słowa kluczowe:}

przedsiębiorczość

innowacje

innowacyjność 


\section{Entrepreneurship and innovation \\ - understanding and \\ delimitation of concepts}

Piotr Kopyciński

The aim of this chapter is to delimit concepts of "entrepreneurship" and "innovation". In order to achieve this intention, it was pointed out understanding of these formulations. Among the various approaches of "entrepreneurship", the focus has been on those connected with innovation.

\footnotetext{
Keywords:

entrepreneurship

innovation

innovativeness
} 


\section{Wstęp}

Znaczenie wyrażeń „przedsiębiorczość" oraz „innowacyjność" ewoluowało w ostatnich latach. Współcześnie pojęć tych używa się w różnych kontekstach i często traktowane są synonimicznie. $Z$ tego względu zasadne jest przybliżenie czytelnikowi różnych znaczeń tych słów, a także zaproponowanie delimitacji, która pozwoli na ich rozróżnienie na potrzeby tematyki przedstawionej $w$ niniejszej monografii. W związku z tym, że problematyce przedsiębiorczości poświęcona jest cała publikacja, $w$ tym tekście pojęcie to będzie omawiane jedynie w zakresie niezbędnym do wspomnianego rozgraniczenia z pojęciem „innowacyjność". Kluczowe będzie za to przedstawienie istoty tej ostatniej.

\section{Rozumienie przedsiębiorczości}

Uściślając prezentowany tok rozumowania, z tytułową kategorią możemy łączyć dwa pojęcia: przedsiębiorczość jako określoną czynność/proces oraz przedsiębiorcę jako osobę realizującą stosowne działania związane z zakładaniem działalności / funkcjonowaniem firmy ${ }^{1}$.

Przedsiębiorczość może być rozumiana jako zdolność i gotowość do rozwijania, organizowania i zarządzania przedsiębiorstwem, uwzględniając wszelkie związane z tym ryzyka, w celu osiągnięcia zysku (Business Dictionary 2018). Z kolei przedsiębiorcą będzie osoba podejmująca tego typu działania. Wśród wielu autorów ten sposób rozumowania potwierdza T. Oleksyn (2012). Wskazuje on, że „przedsiębiorca to człowiek, który jest jednocześnie założycielem firmy, osobiście nią zarządza i sam ponosi pełne ryzyko i odpowiedzialność finansową, związane z jej prowadzaniem" (Oleksyn 2012, s. 11). Przedsiębiorca szuka więc szans na biznes, ponosząc stosowne ryzyko finansowe, ale niekoniecznie samodzielnie tworzy te szanse.

Natomiast w innym podejściu za przedsiębiorcę uważa się jednostkę, która posiada umiejętność znajdowania i wykorzystywania możliwości oraz przekuwania pomysłów na nowe produkty. W takim ujęciu przedsiębiorca potrafi rozpoznać komercyjny potencjał danego produktu, a także, przy wykorzystaniu talentu i kapitału, zamienić inwencję w innowację. W tym podejściu pojęcie „przedsiębiorczość" obejmuje tak- 
że aktywność innowacyjną zarówno istniejących, jak i powstających przedsiębiorstw (Audretsch i in. 2002).

Z powyższego można więc wnioskować, że omawiane sformułowania nie są jednoznaczne. Jak można zauważyć, w pierwszym z przedstawianych podejść na główny plan wysuwa się łączenie pojęć "przedsiębiorca" $i$ „przedsiębiorczość" z zarządzaniem firmą. W takim ujęciu w przedsiębiorstwie mogą powstawać innowacje, ale projektującym zmiany niekoniecznie będzie tak rozumiany przedsiębiorca. W drugim zaś podejściu pojęcia te wiążą się bezpośrednio z innowacyjnością. Przyjmując, z racji tematyki niniejszego tekstu, tę drugą optykę, można mówić o trzech podejściach do przedsiębiorczości (Bal-Woźniak 2007):

1. Przedsiębiorczość w kontekście znaczenia przedsiębiorcy w rozwoju społeczno-gospodarczym.

2. Analiza natury przedsiębiorczości i składowych jej struktury wewnętrznej.

3. Upowszechnianie przedsiębiorczości opartej na innowacyjności.

Z perspektywy rozważań w niniejszym artykule szczególnie istotne jest to ostatnie podejście. Przedsiębiorczość oparta na wiedzy, wykorzystująca takie narzędzia jak innowacje i innowacyjności, jest współcześnie niezbędnym czynnikiem sukcesu firm (Bal-Woźniak 2007). W takim ujęciu można powiedzieć, że nie ma przedsiębiorczości bez innowacyjności.

W tym kontekście należy odwołać się do dorobku jednego z prekursorów rozważań na temat innowacyjności - J. Schumpetera. Widzi on ścisłe powiązanie pomiędzy tą problematyką a przedsiębiorczością. Jak wskazuje, przy powstawaniu "nowych kombinacji” środków produkcji (jak nazywał wówczas innowacje) kluczowe znaczenie ma przedsiębiorca, którego pomysłowość, siła perswazji i wola pozwalają zorganizować nowe przedsiębiorstwo i przeprowadzić innowację: "Czynnikiem konstytuującym przedsiębiorcę jest realizowanie nowych kombinacji" (Schumpeter 1960, s. 118).

Na podstawie powyższych rozważań możemy wskazać dwa podejścia do problematyki przedsiębiorczości, z których w pierwszym na główny plan wysuwają się zagadnienia zarządzania firmą, a w drugim kwestie związków między omawianą kategorią a innowacyjnością. Skoro w niniejszej pracy przyjęto, że szczególnie istotny jest ten drugi związek, to powstaje pytanie o rozumienie innowacyjności. Przyjrzyjmy się zatem bliżej tej problematyce. 


\section{Rozumienie innowacyjności}

Na wstępie warto podkreślić, że często można spotkać się z zamiennym używaniem pojęć „innowacja” i „innowacyjność”. Ich znaczenie jest jednak różne. Zdefiniowanie innowacyjności jest stosunkowo proste - można ją rozumieć jako zdolność określonych podmiotów do wdrażania nowych pomysłów. Sprawa komplikuje się przy doprecyzowywaniu pojęcia „innowacja”. W tym przypadku, oprócz różnych szczegółowych klasyfikacji, istotne są dwa podejścia. W pierwszym, nazwijmy je klasycznym, innowacje są traktowane jako indywidualny problem przedsiębiorcy (przedsiębiorstwa). To zadaniem firmy jest wymyślić, zaprojektować, przetestować i wdrożyć stosowne rozwiązanie na rynku. Mogą to być innowacje technologiczne (produktowe i procesowe) lub nietechnologiczne (organizacyjne i marketingowe). W drugim zaś ujęciu, które pojawiło się stosunkowo niedawno, zwraca się uwagę na społeczny (kolektywny) wymiar powstawania nowych rozwiązań. Drugoplanowy zaś staje się rodzaj wdrażanej innowacji. W tym podejściu innowacje powstają w ramach interakcji różnych osób i podmiotów, wychodząc naprzeciw oczekiwaniom określonych grup. Pojawia się tu cały katalog podejść. Mówimy o innowacjach społecznych (np. Murray, Caulier-Grice, Mulgan 2010; BEPA 2011) i ich szczególnym przypadku -innowacjach miejskich (Kopyciński 2018), podkreślamy powstawanie innowacji we współpracy z szerokim spektrum aktorów (open innovation, por. Chesbrough, Vanhaverbeke, West 2006) czy wręcz przy udziale przyszłych użytkowników w tworzeniu rozwiązań spełniających ich oczekiwania (user innovation, democratizing innovation - por. E. von Hippel 2005; living labs - np. World Bank 2014, collaborative innovation - np. J. Torfing 2016). Możemy więc mówić o ewolucji rozumienia innowacji od ujęcia stricte technologicznego w kierunku rozumienia społecznego, gdzie znaczenia nabierają takie procesy jak: kooperacja, współtworzenie (co-creation), wzajemne uczenie się czy współdzielenie (co-sharing).

Należy przy tym podkreślić, że dwa prezentowane wyżej podejścia wzajemnie się nie wykluczają, są to po prostu dwie perspektywy badań nad innowacjami. Możemy więc przykładowo mówić o innowacji produktowej powstałej w wyniku interakcji/zapotrzebowania społecznego (swoista "społeczna innowacja produktowa"). Aby szerzej zrozumieć te zawiłości, przyjrzyjmy się szczegółowo klasyfikacji innowacji.

Wśród współczesnych propozycji rozumienia pojęcia „innowacja” z pewnością ważne jest ujęcie zaproponowane na początku XX w. przez 
J. Schumpetera. Według tego autora innowacja to nowa kombinacja środków produkcji obejmująca:

„1. Wprowadzenie nowego towaru [...] lub nowego gatunku jakiegoś towaru $[\ldots]$;

2. Wprowadzenie nowej metody produkcji [...] (polegającej) np. na nowym handlowym sposobie postępowania z jakimś towarem;

3. Otwarcie nowego rynku, tj. rynku, na którym dana gałąź przemysłu danego kraju nie była uprzednio wprowadzona [...];

4. Zdobycie nowego źródła surowców lub półfabrykatów [...];

5. Przeprowadzenie nowej organizacji jakiegoś przemysłu..." (Schumpeter 1960, s. 104).

Współcześnie, po okresie przywiązywania wagi przede wszystkim do zmian technologicznych (innowacje produktowe i procesowe), można zauważyć wzrost zainteresowania szerokim, schumpeterowskim rozumieniem innowacji. Do jego koncepcji nawiązują autorzy Podręcznika Oslo wspólnej publikacji Organizacji Współpracy Gospodarczej i Rozwoju (OECD) oraz Europejskiego Urzędu Statystycznego (Eurostat) odnoszącej się do problematyki gromadzenia i wykorzystania danych na temat działalności innowacyjnej w sektorze przedsiębiorstw. W tym opracowaniu wskazano, że „innowacja (innovation) to wdrożenie nowego lub znacząco udoskonalonego produktu (wyrobu lub usługi) lub procesu, nowej metody marketingowej lub nowej metody organizacyjnej w praktyce gospodarczej, organizacji miejsca pracy lub stosunkach z otoczeniem" (OECD 2008, s. 48-49). We wspomnianej publikacji zwraca się uwagę na cztery typy innowacji, odzwierciedlające zmiany w działalności przedsiębiorstw:

$\rightarrow$ innowacje produktowe (nowe lub znacząco udoskonalone produkty i usługi),

$\rightarrow$ innowacje procesowe (znaczące zmiany w metodach produkcji i dostarczania),

$\rightarrow$ innowacje organizacyjne (np. zmiany organizacyjne w zakresie działania, miejsca pracy czy stosunkach firmy z otoczeniem),

$\rightarrow$ innowacje marketingowe (OECD 2008).

Nawiązanie do tego podejścia można znaleźć np. w pracy J.S. Metcalfe'a, który dokonuje klasyfikacji innowacji, uwzględniając stopień nowości. Autor ten zwraca uwagę, że jedynie niewielka liczba innowacji polega na zastąpieniu dotychczas stosowanych produktów lub procesów nowymi rozwiązaniami. Takie usprawnienia nazywa innowacjami 
radykalnymi (radical). Znacznie większa liczba innowacji przyjmuje charakter przyrostowy (incremental), polegający na usprawnieniu dotychczas funkcjonujących rozwiązań (Metcalfe 2000). Przykładowo, pojawienie się telefonów komórkowych można uznać za radykalną zmianę na tle aparatów stacjonarnych, natomiast wprowadzanie nowych modeli smartfonów, o ile nie towarzyszy temu wdrażanie nowej technologii, np. w zakresie przesyłu danych, to zmiana przyrostowa.

W kontekście rozciągania pojęcia "innowacja" na kolejne kategorie warto również zwrócić uwagę na sformułowanie, które pojawiło się stosunkowo niedawno - innowacja społeczna (social innovation). Jest ono wykorzystywane w odniesieniu do nowych pomysłów (produktów, usług), które z jednej strony wychodzą naprzeciw oczekiwaniom społecznym (są bardziej efektywne niż rozwiązania alternatywne), a z drugiej przyczyniają się do poszerzenia możliwości współpracy i tworzenia więzi społecznych (Murray i in. 2010). Innowacje społeczne powstają na styku sektorów: publicznego, prywatnego i tzw. trzeciego przy współudziale osób indywidualnych (BEPA 2011). Podmiotami, które uczestniczą w procesie współtworzenia nowego rozwiązania, mogą być: przedsiębiorstwa, obecni lub przyszli użytkownicy danego dobra, instytucje otoczenia biznesu i finansujące, instytucje naukowe czy władze publiczne różnych szczebli. Szczególnym przypadkiem innowacji społecznych są innowacje miejskie, które rozwiązują określone problemy na obszarach zurbanizowanych i powstają przy współudziale tzw. użytkowników miasta (czyli nie tylko mieszkańców, lecz także np. dojeżdżających do pracy spoza miasta) (Kopyciński 2018). Może to być rozwiązanie o charakterze technologicznym (np. aplikacja do wyszukiwania połączeń komunikacji publicznej) bądź nietechnologicznym (np. stworzenie parku miejskiego).

Globalna konkurencja przyczynia się do skracania cyklu życia produktu, a jednocześnie wykorzystywanie coraz bardziej zaawansowanych technologii sprawia, że wprowadzanie innowacji na rynek jest dla przedsiębiorstw coraz bardziej ryzykowne i kosztowne. Następuje umiędzynarodowienie funkcji przedsiębiorstw, w szczególności tych wymagających dużych nakładów wiedzy ( $w$ tym w zakresie B+R). Firmy stają się coraz bardziej otwarte na kooperację z innymi podmiotami przy wdrażaniu innowacji. Stopień otwartości zależy zaś od wykorzystywanych technologii, specyfiki sektora i strategii przedsiębiorstwa. Opisane tu procesy zostały określone przez H. Chesbrougha jako open innovation, co może być tłumaczone jako "koncepcja otwartej innowacji", a powstające w wyniku owych działań nowe 
rozwiązanie jako „otwarta innowacja” (Chesbrough i in. 2006, s. 1). Sformułowanie to stworzono na potrzeby sytuacji, $w$ której nowe rozwiązanie powstaje we współpracy z szerokim spektrum aktorów. Jednocześnie prawa do prac, które po wdrożeniu innowacji zostały uznane przez przedsiębiorstwo za zbędne, znajdują nabywców wśród podmiotów zewnętrznych. Te ostatnie z kolei wykorzystują je do własnych celów - wprowadzenia nowych lub udoskonalania dotychczasowych produktów (usług) (OECD 2008a).

W kontekście niniejszych rozważań warto również zapoznać się $z$ trendem nazywanym demokratyzacją innowacji (democratizing innovation). Koncepcję tę szerzej przedstawił w swej pracy z 2005 r. E. von Hippel. Mając na myśli demokratyzację innowacji, zwraca uwagę na wzrastające możliwości prowadzenia działalności innowacyjnej na własne potrzeby przez użytkowników produktów i usług - zarówno podmioty gospodarcze, jak i osoby indywidualne (Hippel 2005). Współcześnie coraz więcej firm, a nawet hobbistów, ma dostęp do nowoczesnych technologii i narzędzi informatycznych, do których uruchomienia wystarczy komputer osobisty. Co więcej, przy niewielkich nakładach pracy mogą być one wykorzystane do powstania nowych produktów i usług spełniających wyrafinowane oczekiwania odbiorców. Możemy więc mówić o demokratyzacji możliwości powstawania innowacji - przyszli użytkownicy zyskują możliwość stworzenia produktów spełniających dokładnie ich oczekiwania (Hippel 2005). Przykładowo: hobbysta dysponujący odpowiednią wiedzą i oprogramowaniem może stworzyć równorzędny względem propozycji wielkiego koncernu system sterowania ruchem $w$ mieście.

Reasumując, można powiedzieć, że w rozważaniach o innowacjach w kategorii zmian technologicznych i nietechnologicznych wprowadzanych przez przedsiębiorstwo towarzyszy też równoległy, niewykluczający pierwszego sposób myślenia, gdzie innowacja powstaje w odpowiedzi na zapotrzebowanie społeczne i jest wynikiem wspólnej pracy wielu podmiotów. W tym drugim ujęciu na dalszy plan schodzi przyporządkowanie takiego rozwiązania do któregoś z typów innowacji według klasyfikacji OECD (technologiczne, nietechnologiczne). Niemniej w obu przypadkach przy wdrażaniu innowacji istotnymi podmiotami są przedsiębiorstwa.

\section{Przedsiębiorczość a innowacyjność - punkty wspólne i różnice}

Dotychczasowe rozważania pozwoliły na zdefiniowanie wyrażeń „innowacje" i „innowacyjność", a w tym kontekście również „przedsiębiorczość" oraz 
„przedsiębiorstwo". W tym miejscu warto zastanowić się nad delimitacją tych dwóch kategorii pojęć. „Innowacyjność zależy od przedsiębiorczości w tym sensie, że może być przez nią pobudzana, ale i odwrotnie - może być bodźcem rozwoju przedsiębiorczości jako źródło szans" (Bogdanienko 2017, s. 34). Niekiedy też przedsiębiorczość jest uważana za składową innowacyjności (Bogdanienko 2017). Tak sądzi np. H. Mizgajska (2010), wskazując, że działalność przedsiębiorstw jest uwarunkowana m.in. klimatem przedsiębiorczości. Z kolei Zahra zwraca uwagę, że organizację przedsiębiorczą musi cechować innowacyjność (Bogdanienko 2017).

Odnosząc się do powyższego oraz do wcześniejszych rozważań o przedsiębiorczości, można więc powiedzieć, że omawiane dwie kategorie pojęciowe są wobec siebie współzależne: w niektórych podejściach innowacyjność zależy od przedsiębiorczości, a w innych odwrotnie. Kluczowe wydaje się przy tym rozróżnienie dwóch omawianych na początku rozdziału podejść do przedsiębiorczości: jeśli traktujemy ją stricte $w$ kategoriach zarządzania firmą, to niekoniecznie musi być ona związana z innowacyjnością. Natomiast przedsiębiorczość rozumiana jako znajdowanie i wykorzystywanie szans rynkowych na wprowadzenie nowych produktów (usług) jest jak najbardziej powiązana $z$ innowacyjnością. Jak więc można opisać te związki wobec wielości podejść, z których część została przedstawiona w niniejszym rozdziale?

W tym celu interesujące jest odwołanie się do propozycji T. Bal-Woźniak. Proponuje ona poniższe podejście (Tab. 1).

Tabela 1. Delimitacja pojęć „innowacyjność” i „przedsiębiorczość" - przykład

INNOWACYJNOŚĆ JAKO NARZĘDZIE PRZEDSIĘBIORCZOŚCI (DRUCKER)

\section{ALE}

PRZEDSIĘBIORCZOŚĆ JAKO ZBIÓR ZACHOWAŃ MOŻE WYSTĘPOWAĆ BEZ INNOWACJI

\section{PODCZAS GDY}

INNOWACJA NIE MOŻE ISTNIEĆ BEZ PRZEDSIĘBIORCZOŚCI

\section{A WIĘC}

INNOWACYJNOŚĆ JAKO ZDOLNOŚĆ DO WDRAŻANIA INNOWACJI JEST JEDNYM Z ZASOBÓW PRZEDSIĘBIORCZOŚCI 
Jak wskazuje T. Bal-Woźniak (2007), przedsiębiorczość jako pewien zbiór zachowań może istnieć bez innowacyjności, ale innowacyjność rozumiana jako zdolność do wdrażania innowacji nie może istnieć bez przedsiębiorczości. Z pewnością jest to istotne spostrzeżenie dotyczące współzależności, przy czym przedsiębiorczość jest tu sformułowaniem dominującym.

\section{Zakończenie}

Jako podsumowanie niniejszego artykułu niech posłużą poniższe zestawienia (Tab. 2 i 3).

Tabela 2. Przedsiębiorczość i przedsiębiorca - rozumienie pojęć

\begin{tabular}{|c|c|c|}
\hline WYRAŻENIE & $\begin{array}{c}\text { UJĘCIE } 1 . \\
\text { ZARZĄDZANIE } \\
\text { PRZEDSIĘBIORSTWEM }\end{array}$ & $\begin{array}{c}\text { UJĘCIE } 2 . \\
\text { WPROWADZANIE ZMIAN W PRZEDSIĘBIORSTWIE } \\
\text { (W ASORTYMENCIE PRODUKTÓW/USŁUG) }\end{array}$ \\
\hline Przedsiębiorczość & $\begin{array}{l}\text { Zdolność i gotowość do } \\
\text { organizowania i rozwijania } \\
\text { działalności przedsiębiorstwa } \\
\text { oraz zarządzania nim w celu } \\
\text { osiągnięcia zysku. }\end{array}$ & $\begin{array}{l}\text { Umiejętność identyfikacji szans i prze- } \\
\text { kuwania ich na innowacje. }\end{array}$ \\
\hline Przedsiębiorca & $\begin{array}{l}\text { Zarządzający - osoba na bie- } \\
\text { żąco kierująca przedsiębior- } \\
\text { stwem, często } \\
\text { właściciel/założyciel, po- } \\
\text { nosząca ryzyko finansowe } \\
\text { funkcjonowania firmy, ale } \\
\text { niekoniecznie odpowiedzialna } \\
\text { za innowacje. }\end{array}$ & $\begin{array}{l}\text { Innowator - osoba posiadająca zdolność } \\
\text { do wprowadzania innowacji. }\end{array}$ \\
\hline
\end{tabular}

Źródło: Opracowanie własne. 
Tabela 3. Innowacja i innowacyjność - rozumienie pojęć

\begin{tabular}{l|l|l}
\multicolumn{1}{c|}{ WYRAŻENIE } & $\begin{array}{c}\text { UJĘCIE 1. INNOWACJA JAKo } \\
\text { PROBLEM PRZEDSIĘBIORSTWA }\end{array}$ & \multicolumn{1}{c}{\begin{tabular}{c}
\multicolumn{1}{c}{ UJĘCIE 2. INNOWACJA JAKO PROBLEM } \\
SPOtECZNY
\end{tabular}} \\
\hline Innowacja & $\begin{array}{l}\text { Nacisk na efekt w postaci } \\
\text { nowego rozwiązania - różne } \\
\text { klasyfikacje, np. bazujące na } \\
\text { teorii J. Schumpetera podej- } \\
\text { ście OECD: innowacje produk- } \\
\text { towe, procesowe, organizacyj- } \\
\text { ne i marketingowe. }\end{array}$ & $\begin{array}{l}\text { Nacisk na współpracę przy wdrażaniu } \\
\text { - innowacja jako konsekwencja współpra- } \\
\text { nikón rozwiązania, przedsiębiorstw, jed- } \\
\text { biznesu, instytucji finansowych i władz } \\
\text { publicznych, będąca spełnieniem zbioro- } \\
\text { wych (kolektywnych) potrzeb. }\end{array}$ \\
\hline Innowacyjność & $\begin{array}{l}\text { Zdolność określonych pod- } \\
\text { miotów (przede wszystkim } \\
\text { przedsiębiorstw) do wdrażania } \\
\text { innowacji. }\end{array}$ & $\begin{array}{l}\text { Zdolność określonych podmiotów } \\
\text { (niekoniecznie przedsiębiorstw) do } \\
\text { wdrażania innowacji. }\end{array}$
\end{tabular}

Źródło: Opracowanie własne.

Reasumując, możemy powiedzieć, że „przedsiębiorczość" i „innowacyjność" to sformułowania współzależne, z tym że w zależności od podejścia ta pierwsza nie musi być powiązana z wprowadzaniem nowości, podczas gdy innowacyjność jest ściśle związana z przedsiębiorczością (w tym miejscu kwestią wtórną pozostaje, która jest zmienną zależną). 


\section{Bibliografia}

$\rightarrow$ Audretsch, D.B. i in. (2002), The Economics of Science and Technology [w:] „The Journal of Technology Transfer", April 2002, Vol. 27, Issue 2, pp. 155-203.

$\rightarrow$ Bal-Woźniak, T. (2007), Innowacyjność fundamentalnym warunkiem przedsiębiorczości powszechnie opartej na wiedzy. Porównania międzynarodowe [w:] M.G. Woźniak, Nierówności społeczne a wzrost gospodarczy. Gospodarka oparta na wiedzy, Rzeszów: Uniwersytet Rzeszowski.

$\rightarrow$ BEPA (2011), Empowering People, Driving Change. Social Innovation in the European Union, Luxembourg: Publications Office of the European Union.

$\rightarrow$ Bogdanienko, J. (2017), Przedsiębiorczość a innowacyjność - dyskurs terminologiczny, „Marketing i Rynek”, nr 11/2017, s. 30-41.

$\rightarrow$ Chesbrough, H., Vanhaverbeke, W., West, J. (2006), Open Innovation: Researching a New Paradigm, Oxford: Oxford University Press.

$\rightarrow$ Von Hippel, E. (2005), Democratizing Innovation, Cambridge, MA/London: The MIT Press.

$\rightarrow$ Kopyciński, P. (2018), City Lab as a Platform for Implementing Urban Innovation. The Role of Companies [w:] K. Wach, M. Maciejewski (red.), (International Entrepreneurship as the Bridge between International Economics and International Business: Conference Proceedings of the 9th ENTRE Conference and 5th AIB-CEE Conference. Cracow: Uniwersytet Ekonomiczny w Krakowie, s. 257-274.

$\rightarrow$ Metcalfe, J.S., (2000), Science, Technology and Innovation Policy in Developing Economies, Paper prepared for the workshop on Enterprise Competitiveness and Public Policies, Barbados 22nd - 25th November 1999.

$\rightarrow$ Mizgajska, H. (2010), Problemy innowacyjności przedsiębiorstw produkcyjnych, "Zeszyty Naukowe Uniwersytetu Ekonomicznego w Poznaniu”, nr 131, s. 9-26.

$\rightarrow$ Murray, R., Caulier-Grice, J., Mulgan, G. (2010), The Open Book of Social Innovation, NESTA.

$\rightarrow$ OECD (2008), Podręcznik Oslo, Paris: OECD \& EUROSTAT.

$\rightarrow$ OECD (2008a), Open Innovation in Global Network, Paris. 
$\rightarrow$ Oleksyn, T. (2012), Przedsiębiorczość jako kategoria złożona. Jak ją rozwijać?, „Problemy Zarządzania”, 10/1(2), s. 8-25.

$\rightarrow$ Schumpeter, J. (1960), Teorie rozwoju gospodarczego, Warszawa: PWN.

$\rightarrow$ Torfing, J. (2016), Collaborative Innovation in the Public Sector, Washington DC: Georgetown University Press.

$\rightarrow$ World Bank \& European Network of Living Labs (2014), Citizen-Driven Innovation: A Guidebook for City Mayors and Public Administrators, Brussels: World Bank \& European Network of Living Labs. 


\section{Netografia}

$\rightarrow$ Business Dictionary, www.businessdictionary.com (dostęp: 15.11.2018). 


\section{Kształtowanie przedsiębiorczości jako narzędzie uwalniania potencjału gospodarczego społeczeństwa i rozwoju społeczno-gospodarczego}

Wojciech Piontek

W tekście podjęta została problematyka kształtowania potencjału przedsiębiorczości społeczeństwa. Przedstawiono współczesną teorię rozwoju społeczno-gospodarczego, ze szczególnym wskazaniem roli przedsiębiorcy i przedsiębiorczości w tym procesie. Określony został zakres polityki państwa na rzecz rozwoju przedsiębiorczości. Przedmiotem analizy są zagadnienia kształtowania atrybutów przewagi konkurencyjnej narodu oraz kapitału ludzkiego. Omówione zostały wybrane czynniki stanowiące zagrożenie dla rozwoju przedsiębiorczości i rozwoju społeczno-gospodarczego.

\section{Słowa kluczowe:}

rozwój społeczno-gospodarczy

konkurencyjność

przedsiębiorczość

kształtowanie przedsiębiorczości

kapitał ludzki

atrybuty przewagi konkurencyjnej 


\section{Shaping entrepreneurship as a tool \\ for releasing the economic potential \\ of the society as well as social \\ and economic development}

Wojciech Piontek

This chapter deals with the problem of shaping the entrepreneurial potential in the society. It presents the contemporary theory of the social and economic development, with special emphasis on the role of an entrepreneur and entrepreneurship in this process. The scope of the state policy for the development of entrepreneurship has also been determined. The subject of consideration are the issues related to shaping the attributes competitive advantage of the nation and human capital. Selected factors that pose a threat to the development of entrepreneurship as well as the social and economic development have also been discussed.

\section{Keywords:}

social and economic development

competitiveness

entrepreneurship

shaping entrepreneurship

human capital

attributes of competitive advantage 


\section{Wstęp}

W okresie od rewolucji przemysłowej i pojawienia się pojęcia przedsiębiorcy w pracach R. Cantillona, pojęcie to, jak i wskazywana rola przedsiębiorczości, w rozwoju gospodarczym ewoluowały. Pozostawały one ściśle związane z etapem rozwoju gospodarki i akceptowanymi w danym okresie teoriami wzrostu i rozwoju gospodarczego. Poszczególne etapy rozwoju wyznaczane są ewolucją źródeł narodowej przewagi na arenie międzynarodowej oraz typem branż przemysłowych odnoszących sukces. Minionymi etapami rozwoju gospodarek w krajach wysokorozwiniętych były etap rozwoju oparty na czynnikach produkcji (ziemia, praca, kapitał) oraz etap rozwoju oparty na inwestycjach. W obecnym etapie o przewadze decydują innowacje. Kolejnym okresem rozwoju będzie etap oparty na majątku narodowym (Porter 1990). Etap ten jest już sygnalizowany w rodzących się nowych nurtach myśli ekonomicznej, w szczególności ekonomii rozwoju, ekonomii stanu stacjonarnego, czy ekonomii współdzielenia. Należy oczekiwać, że wymusi on redefiniowanie pojęcia przedsiębiorcy i znaczenia przedsiębiorczości dla rozwoju społeczno-gospodarczego.

\section{Przedsiębiorczość w teorii rozwoju społeczno-gospodarczego}

Zagadnienie znaczenia przedsiębiorczości dla rozwoju społeczno-gospodarczego jest silnie zróżnicowane w ramach szkół i nurtów teorii ekonomii. Współczesne rozumienie pojęć rozwoju, przedsiębiorcy oraz rola przedsiębiorczości w stopniu znaczącym zostało zdefiniowane przez J. Schumpetera (1960), a następnie rozwinięte w licznych pracach ekonomistów, jak i koncepcjach polityczno-gospodarczych. Bezpośrednie lub pośrednie odniesienia, nawiązania i rozwinięcia teorii zawarte zostały między innymi w pracach: P. Druckera, I. Kirznera, J.K. Galbraitha, E.D. Domara, P.M. Romera. Autorzy ci akcentują konieczność nieustannej innowacyjności, przedsiębiorczości i nowych strategii działania w szybko zmieniającym się świecie jako warunków koniecznych dla zapewnienia wzrostu i rozwoju społeczno-gospodarczego.

Schumpeterowski rozwój jest procesem obejmującym:

$\rightarrow$ Zmiany w życiu ekonomicznym powstające z własnej inicjatywy, od wewnątrz. Zmiany narzucane z zewnątrz, wynikające z od- 
działywania czynników zewnętrznych, mają charakter wyłącznie dostosowawczy, a rozwój jako taki nie występuje'1.

$\rightarrow$ Występowanie zjawisk jakościowo nowych. Rozwojem nie jest proces wzrostu liczby ludności i bogactwa pozbawiony zjawisk jakościowo nowych. Proces taki ma charakter wyłącznie zmiany danych.

$\rightarrow$ Żywiołowość nie posiadającą charakteru ciągłego zmianą drogi ruchu okrężnego oraz zakłócaniem stanu równowagi w gospodarce.

$\rightarrow$ Pięć kategorii procesów - wprowadzanie nowych towarów, wprowadzanie nowych metod (technologii) produkcji, otwieranie nowych rynków, zdobywanie nowych źródeł surowców lub półfabrykatów, przeprowadzenie nowej organizacji jakiegoś przemysłu. (Schumpeter 1960).

W zbudowanych na fundamencie szkoły schumpeterowskiej teoriach i modelach rozwoju/wzrostu endogenicznego eksponuje się wewnętrzne czynniki wzrostu, na które można oddziaływać i kształtować zgodnie z wyznaczonymi celami. Ich wpływ na wzrost i rozwój pozostaje funkcją zainwestowanego kapitału, jak również innych podejmowanych działań. Wśród wskazywanych czynników rozwoju podstawowe znaczenie przypisuje się kapitałowi ludzkiemu. Wysoko wykwalifikowane i przedsiębiorcze społeczeństwa są źródłem innowacyjności, postępu technologicznego i w konsekwencji decydują o wzroście i rozwoju społeczno-gospodarczym. Kreowanie wzrostu gospodarczego wymaga od podmiotów odpowiedzialnych za funkcjonowanie gospodarek nieustannego kształcenia społeczeństwa zgodnie z przyszłymi, prognozowanymi trendami rozwojowymi oraz pobudzania i ukierunkowywania innowacyjności i przedsiębiorczości.

Przedstawiony mechanizm rozwoju nie jest pozbawiony wad. Innowacyjność i postęp technologiczny stwarzają jedynie gospodarce możliwość wzrostu i nie gwarantują, że wzrost zostanie zrealizowany. Innowacyjność odpowiada za immanentną cechę gospodarki wolnorynkowej jaką jest bezrobocie (Domar 1962) Jednocześnie przedsię-

1. Zgodnie z przedstawionym podejściem, działania na rzecz dostosowania polskiej gospodarki, infrastruktury do wymogów definiowanych i narzucanych przez UE i realizowanych już w innych państwach nie jest procesem rozwoju gospodarczego. 
biorcom współczesna ekonomia przypisuje funkcję kreowania nowych potrzeb i popytu na innowacyjne produkty. Bierność przedsiębiorcy w kreowaniu nowych potrzeb i popytu skutkuje brakiem wzrostu i rozwoju gospodarczego.

Schumpeterowski przedsiębiorca jest szczególnym typem człowieka, posiadającym przywilej tworzenia nowych kombinacji środków produkcji i tworzącym nową wiedzę (Schumpeter 1960). Bycie przedsiębiorcą pozostaje ściśle związane z funkcją i działaniami na rzecz tworzenia innowacyjności (Glapiński 2012). Przedsiębiorca zaprzestający działań na rzecz tworzenia innowacji przestaje być przedsiębiorcą i staje się biznesmenem. Cechami charakteryzującymi osobę, które pozwalają stać się przedsiębiorcą, są: zdolność przewodzenia, umiejętność odejścia od utartych ścieżek postępowania oraz odporność na krytyczne reakcje środowiska (Glapiński 2012). W prowadzonej analizie schumpeterowskiej teorii przedsiębiorcy równie ważnymi i ciekawymi są motywy działania przedsiębiorców, w szczególności: „marzenie i chęć stworzenia prywatnego królestwa i zwykle, choć niekoniecznie - również dynastii (...); pragnienie zdobywania: chęć do walki, do okazania swej wyższości nad innymi, do zwyciężania nie dla jego owoców, lecz dla samego zwyciężania. Z tego punktu widzenia działanie ekonomiczne staje się czymś podobnym do sportu (...); radość tworzenia, dokonania czegoś lub po prostu ćwiczenia swej energii i pomysłowości" (Schumpeter 1960, s.148-150).

Potwierdzeniem znaczenia shumpeterowskiego podejścia do zagadnienia rozwoju i teorii przedsiębiorczości jest analiza mechanizmów wzrostu i rozwoju gospodarek wysokorozwiniętych. Stanowi ono także fundament teoretyczny koncepcji rozwoju gospodarczego Unii Europejskiej w XXI w. Przedstawiona przez UE koncepcja gospodarki niskoemisyjnej i oszczędnej w zasoby jest próbą budowy międzynarodowej przewagi konkurencyjnej i wzrostu gospodarczego Europy w oparciu o tworzenie nowej wiedzy $\mathrm{i}$ innowacje $w$ zakresie zmniejszania negatywnego oddziaływania procesów gospodarowania na środowisko przyrodnicze. Słuszne wydaje się zatem twierdzenie, że "nadchodzq̨cy okres stanie się "erq schumpeterowskq»" (Mikosik 1960, s. XII). Czynnikami rozwoju gospodarczego będą rządziły precyzyjnie ukierunkowany proces innowacji i kreacja kredytu. W pełni aktualna pozostaje także teza F.A. von Hayeka, że fundamentem dla podejmowanych działań jest akt wiary, iż nauka zapewni konieczny poziom innowacyjności, dyfuzji roz- 
wiązań oraz że zadziała efekt mnożnika. Przedsiębiorca w XXI w. będzie przedsiębiorcą schumpeterowskim nieustannie tworzącym nową wiedzę, a co zatem następuje kształtowanie przedsiębiorczości wymaga kształtowania cech i zmiennych wskazywanych przez J. Schumpetera.

\section{Kształtowanie przedsiębiorczości}

Rozwój gospodarczy, społeczny i kulturowy nie następuje samoczynnie. Jest wynikiem działań państwa tworzącego uwarunkowania rozwoju oraz aktywności przedsiębiorców (Zioło 2015). Wymaga prowadzenia świadomej polityki rozwoju przedsiębiorczości, ukierunkowanej na kształtowanie atrybutów przewagi konkurencyjnej oraz kapitału ludzkiego. Charakter ingerencji państwa w przebieg procesów gospodarczych określił F.A. von Hayek w Konstytucji wolności (2012) wskazując, że fundamentem funkcjonowania gospodarki wolnorynkowej winny być rządy prawa tworzonego w oparciu o prawo naturalne. Prawo stanowione tworzone na gruncie prawa naturalnego ze swej istoty przeciwdziała negatywnym skutkom procesów gospodarczych. „Cała ta działalność państwa ma stwarzać sprzyjające warunki do podejmowania decyzji indywidualnych, dostarczać środków, których jednostki mogą użyć do własnych celów. Do tej samej kategorii należy również wiele innych usług o charakterze bardziej materialnym. Chociaż rządowi nie wolno wykorzystywać swej władzy przymusu w celu rezerwowania dla siebie rodzajów działalności" (Hayek 2012, s. 223). Hayekowski prymat rządów prawa tworzonego w oparciu o prawo naturalne został odrzucony na rzecz "wolności gospodarczej" przez szkołę chicagowską. Fałszywie rozumiana "wolność gospodarcza" może jednak stać się źródłem negatywnych zjawisk i procesów, w tym niszczących przedsiębiorczość.

Celem działań państwa w zakresie rozwoju przedsiębiorczości jest budowanie przewagi konkurencyjnej narodu opisanej przez "teorię przewagi konkurencyjnej narodów" M. Portera. Poszukiwanie czynników konkurencyjności na poziomie krajowym jest błędem. Należy poszukiwać odpowiedzi na pytania co determinuje wydajność oraz tempo jej wzrostu na poziomie poszczególnych branż (działów) przemysłu. Jak wskazuje M. Porter szczegółowa analiza poszczególnych gospodarek pozwala wskazać istotne między nimi różnice, w konsekwencji zaś dokonać identyfikacji cech narodowych przyczyniających się do uzyskania przewagi konkurencyjnej przez przedsiębiorstwa. Cechy te są zarazem czynnikami przewagi konkurencyjnej danego państwa. 
Szczególnie znaczącym i istotnym jest dokonane przez M. Portera (1990) spostrzeżenie, że w skali świata, podmioty gospodarcze posiadające rzeczywistą międzynarodową przewagę konkurencyjną zbudowały ją bazując na cechach jedynie kilku narodów. Źródeł przewagi konkurencyjnej państw Porter upatruje w czterech atrybutach tworzących tzw. diament przewagi konkurencyjnej: czynnik otoczenia, czynnik popytu, obecność w kraju powiązanych i wspierających się branż oraz strategie firm, struktura i rywalizacja. Atrybuty te winny być przedmiotem szczególnej troski zarządzających państwami. Wymagają nieustannego kreowania i podtrzymywania. Atrybuty określają charakter krajowego otoczenia, w którym przedsiębiorstwa powstają i uczą się konkurować. Każdy z atrybutów z osobna, jak i wszystkie jako system kształtują uwarunkowania niezbędne do osiągnięcia przez przedsiębiorstwa międzynarodowej konkurencyjności. Do uwarunkowań tych zaliczyć należy: dostępność zasobów i umiejętności; dostępność informacji rynkowych stwarzających szansę, iż przedsiębiorstwa dostrzegą kierunki, w których należy rozmieścić umiejętności i zasoby; cele właścicieli, menedżerów oraz pracowników w spółkach; presję na przedsiębiorstwa do inwestowania i wdrażania innowacji. Najważniejszym z uwarunkowań decydujących o uzyskiwaniu przez państwo międzynarodowej przewagi konkurencyjnej jest nieustannie wywierana na przedsiębiorstwa presja (Porter 1990).

Równie istotnym, co diament przewagi konkurencyjnej, czynnikiem rozwoju społeczno-gospodarczego jest kapitał ludzki (pośrednio wpisany w atrybuty tworzące diament). Kapitał ten określają system wartości moralnych, cechy osobowościowe, zasób wiedzy użytecznej i nieużytecznej. Proces budowy kapitału obejmuje kształtowanie wskazanych cech, jak również przeciwdziałanie zjawiskom i procesom niekorzystnym i destrukcyjnym. Kształtowanie kapitału ludzkiego jest procesem długotrwałym i szczególnie złożonym.

Wartości moralne determinują przyjmowane postawy, przekonania, a także ukierunkowują życie jednostki, jak i społeczeństwa. System wartości przedsiębiorcy działającego w warunkach gospodarki kapitalistycznej powinien bazować na wskazywanym przez F.A. von Hayeka prawie naturalnym. W swoich działaniach przedsiębiorca powinien pozostawać w zgodzie z "zasadą uświęconą przez czas «nie czyń drugiemu, co tobie niemiłe»" oraz "przynajmniej w miernym stopniu trzymać się podstawowych zasad moralnych" (Anderson 1998, s. 152). Jak wska- 
zuje Sider (1997) odrzucenia wymaga między innymi wszechobecna chciwość, która "stała się główną wadą zachodniej cywilizacji” (Sider, 1977, s.123). Kierowanie się wskazanymi zasadami stanowi warunek konieczny, aby rozwój przedsiębiorczości współistniał z rozwojem społecznym. Przedsiębiorcy odrzucający wskazane wartości, przyczyniają się wyłącznie do rozwoju gospodarczego. Ich działalność nie przyczynia się do rozwoju potencjału społecznego, w skrajnych przypadkach prowadzi do jego zniszczenia.

Wśród wymagających kształtowania przez państwo cech osobowościowych przedsiębiorcy istotne miejsce zajmują odpowiedzialność, zdolności przywódcze oraz wiedza. W literaturze odpowiedzialność przedsiębiorcy definiowana jest jako gotowość lub konieczność ponoszenia konsekwencji pozytywnych i negatywnych efektów wewnętrznych i zewnętrznych podejmowanych decyzji i działań (Piontek 2018). Odpowiedzialność przedsiębiorcy może być odpowiedzialnością naturalną lub zrelatywizowaną. Szczególnie pożądanym jest kształtowanie odpowiedzialności rozumianej w sensie naturalnym, będącej odpowiedzialnością obiektywną i absolutną, pozbawioną relatywizmu. Nie odnosi się ona do obowiązującego w danym momencie systemu normatywnego, a bezpośrednio wynika z prawa naturalnego. Pozostaje niezmienna w czasie. (Kruszyński 2015). Zapewnia przestrzeganie zasady „nie czyń drugiemu, co tobie nie miłe”, a działalność przedsiębiorcy służy dobru ogólnemu. Jej przeciwieństwem jest odpowiedzialność zrelatywizowana, definiowana przez obowiązujący w danym czasie system normatywny. Podlega zmianom w czasie wraz ze zmianami systemu normatywnego, na bazie którego jest formułowana. (Kruszyński 2015). Na płaszczyźnie gospodarczej podporządkowana jest doktrynie nieustającego wzrostu gospodarczego. Pozwala na ocenianie zachowań moralnie nagannych jako odpowiedzialnych oraz ekonomicznie i społecznie pożądanych. Przykładami koncepcji urzeczywistniających zrelatywizowaną odpowiedzialność przedsiębiorcy są koncepcja społecznej odpowiedzialności biznesu oraz koncepcja rozszerzonej odpowiedzialności producenta.

Wskazywanymi przez J. Schumpetera cechami przedsiębiorcy są zdolność przewodzenia, umiejętność odejścia od utartych ścieżek postępowania, odporność na krytyczne reakcje środowiska. Cechy te nie są pożądane w świecie podporządkowanym interesom globalnych korporacji. Ich przedstawiciele deklarując swoje oczekiwania wobec 
procesów kształcenia na uczelniach wyższych, wśród pożądanych cech przyszłych pracowników wskazują: umiejętność pracy w zespole, umiejętność podporządkowania się obowiązującym w organizacji zasadom, czy wąską specjalizację w zakresie kompetencji. Przeprowadzone w Polsce badania w zakresie preferowanych przez pracowników, jak i kadrę managerską systemów zarządzania wykazały, że wartości takie jak samodzielność, autonomia, odpowiedzialność są wartościami wyłącznie środowiska naukowego, które usiłuje je imputować społeczeństwu. Zarówno kadra menadżerska, jak i pracownicy nie dążą do wyzwolenia się z przywództwa i preferują autokratyczny system zarządzania (Haromszeki, Jarco 2014).

Fundamentem zdolności innowacyjnych przedsiębiorcy jest szeroki zakres wiedzy użytecznej i nieużytecznej z różnych dziedzin nauki. Umożliwia on poszukiwanie interdyscyplinarnych powiązań i możliwości rozwoju, a w konsekwencji tworzenie „epokowych innowacji”. Odrzucenia wymaga pogląd nawołujący do eliminacji z programów nauczania treści "niezwiązanych z życiem", które mają sprawiać, iż kształcenie jest mało atrakcyjne i nie służy wyzwalaniu motywacji i ciekawości intelektualnej (Gęsicki 2004). Wiedza "niezwiązana z życiem" stanowi potencjał tworzenia nowej wiedzy i innowacji. Dziedziny nauki takie jak filozofia, logika, historia kształtują system wartości moralnych, jak i zdolności logicznego myślenia, dedukcji. Podnoszenie wśród społeczeństwa zasobu wiedzy stanowi podstawę, a nie czynnik rozwoju i wzrostu poziomu życia. Warunkiem koniecznym rozwoju jest przekształcanie natury społeczeństwa i wprowadzanie zmian w sposobie wyobrażania przez członków społeczeństwa przyszłego życia zarówno swojego, jak i swoich dzieci. Wizja przyszłości musi być na tyle silna, aby powodować zmiany w zachowaniu (Lucas 2010).

\section{Procesy i zjawiska destrukcyjne}

Dla rozwoju przedsiębiorczości równie istotne jest przeciwdziałanie procesom i zjawiskom niepożądanym i destrukcyjnym. Wśród przykładowych zagrożeń można wskazać destrukcyjną funkcję mediów, internetu i wirtualnej rozrywki oraz obniżanie się poziomu edukacji. $\mathrm{Na}$ problem jakości kształcenia w wyniku traktowania szkoły wyższej jako zwykłego przedsięwzięcia biznesowego i masowości studiów, szczególnie niestacjonarnych, zwracało uwagę wielu autorów, m.in. K. Równy (2008) i A. Boczkowski (2014). W następstwie rozwoju wyższych szkół 
prywatnych na studia przyjmowani byli i są wszyscy bez specjalnych wymogów w zakresie poziomu wiedzy, gdyż bardzo często jedynym kryterium przyjęcia na studia jest posiadanie matury. Z upływem czasu problem ten zaczął dotykać także niektóre uczelnie państwowe, przyjmujące każdego chętnego absolwenta szkoły średniej na mniej popularne kierunki w warunkach niżu demograficznego. Na problem ten zwróciła uwagę także Najwyższa Izba Kontroli w 2018 r., która w raporcie z kontroli za lata 2015-2017 wskazała, że jednym z poważnych problemów jakości kształcenia w szkołach wyższych są niewystarczające wymogi selekcyjne wobec kandydatów na studia (NIK 2018).

Kolejnym problemem edukacji na poziomie wyższym jest tendencja do upraktyczniania kształcenia. Zalążkiem tego procesu był funkcjonujący w minionych dziesięcioleciach pogląd, że wiedza teoretyczna ma znaczenie wtórne wobec praktyki. Podkreślenia wymaga, że zadaniem szkół wyższych jest wyposażenie studenta w jak najszerszy zasób wiedzy ze studiowanej dziedziny, przedstawienie kierunków rozwoju dziedziny, a także kształtowanie umiejętności analitycznych i twórczych. Proces edukacji akademickiej nie może więc być przesadnie ukierunkowany na przygotowanie studenta pod potrzeby przyszłego pracodawcy. Działanie takie może skutkować przekształcaniem szkół wyższych w szkolnictwo zawodowe. Umiejętność pracy w zespole, czy obsługi programów księgowych, magazynowych i liczne pozostałe umiejętności praktyczne ułatwiają funkcjonowanie studenta na rynku pracy najemnej i są być może chętnie widziane przez pracodawców. Przy takim nieprzemyślanym podejściu do kształcenia na poziomie wyższym w celu przygotowania do konkretnej pracy najemnej, trudno jednak kształtować postawy przedsiębiorcze, w tym kreatywność oraz przygotowywać studentów do założenia i prowadzenia własnego biznesu, szczególnie innowacyjnego. Koncentracja procesu edukacji na nabywaniu przez studentów umiejętności praktycznych wpływa negatywnie na potencjał rozwojowy społeczeństwa i zdolność tworzenia nowej wiedzy. Tym samym utrudnia bycie przedsiębiorcą.

Istotnym czynnikiem obniżania narodowego potencjału przedsiębiorczości i innowacyjności są media, internet i wirtualna rozrywka. Wywołują one wskazywane przez M. Spitzera (2015) zjawisko „cyfrowej demencji". Negatywnie wpływają na kształtowanie się neuronalnej sieci mózgu. Wyniszczają zdolności koncentracji i kontemplacji. W sposób istotny zaburzają mechanizm uczenia się, zapamiętywania, uwagi 
i rozwoju. Dzieje się tak wtedy, gdy Internet nie jest traktowany przez jego użytkowników jako narzędzie do pozyskiwania źródeł wiedzy (np. przeszukiwania baz bibliotecznych i pozyskiwania artykułów), a sam w sobie jest źródłem wiedzy. Niestety powszechne stało się bezrefleksyjne korzystanie z informacji przygotowanych przez innych. Zastępuje ono poszukiwanie i zgłębianie źródeł wiedzy, rozważne i krytyczne spojrzenie na zdobyte informacje, weryfikację wiarygodności oraz zdolność wnioskowania (Spitzer 2015).

Wyniki analiz M. Spitzera znajdują potwierdzenie w analizie kompetencji i postaw młodzieży szkół podstawowych, średnich oraz studentów uczelni wyższych. Nieliczni posiadają zdolność do refleksji nad zadanym do przeczytania tekstem, czy oglądanym filmem. Narasta wśród młodzieży (a także społeczeństwa jako całości) problem ze zrozumieniem czytanego tekstu, wynikający jak wskazują naukowcy z braku umiejętności koncentracji oraz zainteresowania tekstem pisanym (Dzierżanowska, Szkolnictwo.pl 2018). Doświadczenie wielu nauczycieli akademickich wskazuje, że część studentów przygotowanie prac semestralnych, zaliczeniowych, licencjackich oraz magisterskich próbuje sprowadzić do kopiowania tekstu z pierwszych wyświetlanych przez przeglądarkę internetową źródeł czy przepisywania książek, a następnie modyfikacji skopiowanego tekstu zgodnie z parametrami działania wykorzystywanego przez szkołę programu antyplagiatowego. Stąd stworzenie Jednolitego Systemu Antyplagiatowego (zob. jsa.opi.org.pl) dla polskich szkół wyższych, powszechny obowiązek korzystania z niego przez uczelnie oraz wysiłek twórców tego typu systemów, aby przeciwdziałać praktykom oszukiwania systemu w celu niewykrycia plagiatu. Na powszechny problem plagiatowania wśród studentów zwracało uwagę wielu autorów, m.in. S. Wawak i K. Woźniak (2005), S. Kawczyński (2007), N. Miranowicz (2011) i M. Łozińska (2018). W takich warunkach, niewątpliwie kończący edukację mogą być biznesmenami prowadzącymi z sukcesami działalność gospodarczą. Niestety w ograniczonym zakresie posiadają kompetencje do bycia przedsiębiorcami w shumpeterowskim znaczeniu.

\section{Podsumowanie i wnioski}

Rola przedsiębiorczości w rozwoju społeczno-gospodarczym w przyszłości będzie nieustannie wzrastała. Rozwój przedsiębiorczości wymaga aktywnego uczestnictwa państwa, wyrażającego prowadzeniem 
polityki rozwoju przedsiębiorczości, kształtowaniem narodowych cech przewagi konkurencyjnej oraz kapitału ludzkiego. W procesie kształtowania kapitału ludzkiego istotnym jest wyraźne rozróżnianie pomiędzy nowocześnie rozumianym przedsiębiorcą, a tradycyjnie pojmowanym biznesmenem, ukierunkowanym tylko na maksymalizację zysków. Przedsiębiorca tworzy nową wiedzę, poszukuje nowych kombinacji środków produkcji. Proces edukacji powinien być ukierunkowany na kształtowanie specyficznych cech charakteryzujących przedsiębiorcę. Równie istotnym jest podejmowanie działań przeciwdziałających procesom i zjawiskom negatywnie wpływającym na potencjał przedsiębiorczości społeczeństwa i hamujących jego rozwój. 


\section{Bibliografia}

$\rightarrow$ Anderson, B. (1998), Zalety wolnej gospodarki [w:] M.W. Hendrickson (red.) Moralność kapitalizmu, Lublin: TheFreeman, Instytut Liberalno-Konserwatywny.

$\rightarrow$ Boczkowski A. (2014), Uniwersytet a kształcenie masowe. Od idei uniwersytetu do ideologii kształcenia na poziomie wyższym [w:] „Przegląd Socjologiczny”, nr 63 (LXIII) / 3, s. 9-37.

$\rightarrow$ Domar, E.D. (1962), Szkice z teorii wzrostu gospodarczego, Warszawa: PWN.

$\rightarrow$ Gęsicki, J. (2004), Przemiany w edukacji [w:] Wymiary życia społecznego, Warszawa: Wyd. Naukowe SCHOLAR.

$\rightarrow$ Glapiński, A. (2012), Schumpeterowska teoria przedsiębiorcy, czyli skąd się bierze pies [w:] „Konsumpcja i Rozwój” nr 1/2012 (2), s. 3-12.

$\rightarrow$ Haromszeki, Ł., Jarco, P. (2014), System wartości menedżerów i pracowników niższego szczebla w świetle badań porównawczych [w:] „Społeczeństwo i Ekonomia" 2(2), s. 34-50.

$\rightarrow$ Hayek, F.A. (2012). Konstytucja wolności, Warszawa: Wyd. Naukowe PWN.

$\rightarrow$ Kawczyński, S. (2007), Problem plagiatowania w szkolnictwie wyższym. Charakterystyka elektronicznego systemu antyplagiatowego [w:] „e-mentor", nr 2, s. 57-62.

$\rightarrow$ Kruszyński, R.J. (2015), Odpowiedzialność naturalna człowieka [w:] Acta Universitatis Lodziensis. Folia luridica, nr 74/2015, Część I - Odpowiedzialność - uwarunkowania etyczne, moralne i prawne.

$\rightarrow$ Lucas, Jr. R.E. (2010), Wykłady z teorii wzrostu gospodarczego, Academia Oeconomica, Warszawa: Wyd. C.H. Beck.

$\rightarrow$ Łozińska, M. (2018), Zjawisko plagiaryzmu w środowisku akademickim [w:] Zeszyty Naukowe Państwowej Wyższej Szkoły Zawodowej w Legnicy, nr 28, s. 189-199.

$\rightarrow$ Mikosik, S., (1960), Przedmowa do wydania polskiego [w:] J.A. Schumpeter, Teoria rozwoju gospodarczego, Warszawa: PWN. 
$\rightarrow$ Miranowicz, N. (2011), Plagiatorstwo - propozycja diagnozy i terapii na podstawie wyników badania ankietowego wśród studentów [w:] „e-mentor", nr 5, s. 26-31.

$\rightarrow$ Piontek, W. (2018), Implementacja rozszerzonej odpowiedzialności producenta do systemu gospodarowania odpadami w Polsce [w:] „Rocznik Ochrona Środowiska", nr 20. s. 1597-1624.

$\rightarrow$ Porter, M.E. (1990), The Competitive Advantage of Nations, Harvard Business Review, March - April.

$\rightarrow$ Schumpeter, J.A. (1960), Teoria rozwoju gospodarczego, Warszawa: PWN.

$\rightarrow$ Sider, R.J. (1977), Rich Christians in an Age of Hunger, Downers Grove: Inter - Varsity Press.

$\rightarrow$ Spitzer, M. (2015), Cyfrowa demencja. W jaki sposób pozbawiamy rozumu siebie i swoje dzieci, Słupsk: Wyd. Dobra Literatura.

$\rightarrow$ Wawak, S., Woźniak, K. (2005), Skuteczny system automatycznego wykrywania plagiatów na przykładzie prac zaliczeniowych studentów Akademii Ekonomicznej w Krakowie [w:] „e-mentor”, nr 5, s. 5-9.

$\rightarrow$ Zioło, Z. (2015), Przedsiębiorczość jako czynnik rozwoju społeczno-gospodarczego układów przestrzennych [w:] „Przedsiębiorczość - Edukacja”, 11, s. 8-23. 


\section{Netografia}

$\rightarrow$ Dzierżanowska T., Czytanie ze zrozumieniem - opis i analiza problemu, szkolnictwo.pl/index.php?id=PU0718 (dostęp: 30.11.2018).

$\rightarrow$ NIK (2018), System oceny jakości kształcenia w szkołach wyższych, Najwyższa Izba Kontroli, Warszawa, maj 2018 r., www.nik.gov.pl/plik/id,18018,vp,20610.pdf, www.nik.gov.pl/plik/id,18017,vp,20609.pdf (dostęp: 26.02.2019).

$\rightarrow$ Równy, K, (2008), Konieczność poprawy jakości prywatnego szkolnictwa wyższego w Polsce, "Nauka”, nr 4/2008, s. 101-120, www.pan.poznan.pl/nauki/N_408_07_Rowny.pdf (dostęp: 26.02.2019). 


\title{
Znaczenie wiedzy finansowej dla rozwoju przedsiębiorczości
}

\author{
Krzysztof Pietraszkiewicz
}

Liczne badania wykazują, że przedsiębiorczości nie tylko można, ale i należy uczyć. Każdy sukces w działalności gospodarczej wymaga bowiem odpowiedniego przygotowania merytorycznego przedsiębiorcy, w tym w zakresie wiedzy finansowej. Jest ona także istotna dla osób prywatnych prowadzących gospodarstwa domowe. Wymaga to opracowania odpowiednich programów nauczania i wdrażania ich w praktyce edukacyjnej na wszystkich poziomach edukacji, już od przedszkola. W rozdziale wskazano na duże znaczenie edukacji ekonomicznej, w tym finansowej w funkcjonowaniu gospodarstw domowych i prowadzeniu przedsiębiorstw w różnych branżach, a także działalności społecznej.

\section{__ Słowa kluczowe: \\ edukacja ekonomiczna \\ edukacja finansowa \\ przedsiębiorca \\ rozwój przedsiębiorczości}




\section{The importance of financial \\ knowledge for the development \\ of entrepreneurship}

Krzysztof Pietraszkiewicz

Numerous studies show that entrepreneurship not only can, but must be taught. Every success in business requires proper preparation of entrepreneur, including in the field of financial knowledge. It is also important for private people who run households. This requires the development of appropriate curricula and their implementation in educational practice at all levels of education, from kindergarten. The chapter indicates the great importance of economic education, including financial knowledge in the functioning of households and running a business in various industries, as well as social activities.

\section{Keywords:}

economic education

financial education

entrepreneur

entrepreneurship development 


\section{Wstęp}

Jak wykazały liczne badania prowadzone w Stanach Zjednoczonych i w innych krajach zachodnich można i należy uczyć przedsiębiorczości (Cieślik 2010). Oczywiście osoby posiadające szczególne predyspozycje są w stanie szybciej osiągnąć sukces w prowadzonej działalności, ale zdobywana wiedza, odpowiednie treningi i solidna praca najczęściej otwierają drogę do sukcesu bardzo wielu osobom.

\section{Wiedza a sukces przedsiębiorcy}

Współcześnie trudno sobie wyobrazić poważny sukces gospodarczy bez odpowiedniego przygotowania merytorycznego i finansowego przedsiębiorcy. Świat gospodarki, nawet w wymiarze lokalnym czy regionalnym, nie wspominając już o globalnym, jest dzisiaj niezmiernie skomplikowany. Od przedsiębiorców, którzy chcą uczestniczyć aktywnie w świadczeniu usług czy wykonywaniu określonych produktów wymagana jest ogromna wiedza merytoryczna dotycząca jakości usług, kwestii związanych z ochroną środowiska, wymaganiami zdrowotnymi, czy też możliwości zastosowania nowych technologii, w tym automatyzacji i coraz częściej sztucznej inteligencji (Rys. 1).

Rys. 1 Potencjał automatyzacji pracy w Polsce i na świecie

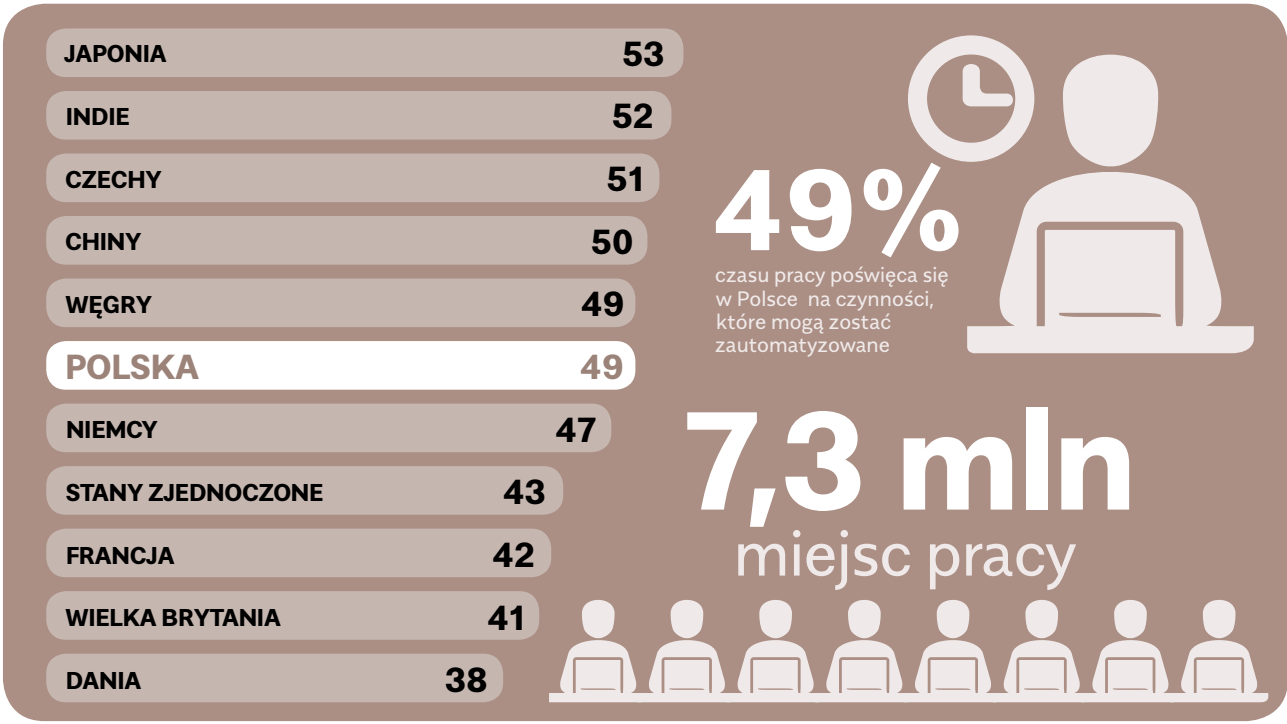

Źródło: Na podstawie McKinsey\&Company/Forbes (2018) 
Współczesny przedsiębiorca czasami kilka razy stoi przed koniecznością dokonania wyboru formy organizacyjnej i prawnej prowadzonej działalności. Możliwości w tym względzie jest wiele i każda z nich ma swoje mocne i słabsze strony. Warto je poznać najpierw w teorii, ponieważ wiele obserwacji wynikających z badań naukowych i ujęć modelowych można z powodzeniem wykorzystać w praktyce (Noga 2009).

Przedsiębiorcy muszą brać pod uwagę fakt, że rozwiązania podejmowane przez konkurentów, zarówno tych bliskich, jak i globalnych mogą często bardzo dynamicznie determinować warunki prowadzenia produkcji czy świadczenia usług. A to, w skrajnych przypadkach może spowodować nie tylko brak sukcesu prowadzonego przedsiębiorstwa, ale wręcz czasami prowadzić do katastrofy gospodarczej. Warunki działania przedsiębiorstwa nie są trwałe i ulegają ciągłym zmianom - dotyczy to wiedzy i oczekiwań klientów, technologii i otoczenia prawnego. Zmienia się również kondycja ekonomiczna i potencjał konkurentów (Lichtarski 2005).

$Z$ tego powodu kompetencje współczesnego przedsiębiorcy muszą opierać się nie tylko na własnych kwalifikacjach, ale także na umiejętności czerpania wiedzy z doświadczeń specjalistów, których może spotkać na uczelniach albo na specjalnie organizowanych kursach, bądź korzystając z dorobku konsultantów i doradców (Kwiatkowski 2000).

Właściwy sposób przygotowywania, zarówno osób prowadzących w przyszłości gospodarstwa domowe, jak i mikro- iśrednie przedsiębiorstwa powinien być realizowany przez kształtowanie nawyków już na płaszczyźnie rodzinnej, czy działania przygotowawcze na poziomie przedszkolnym, ale też naukę w szkole podstawowej, średniej i na studiach wyższych. Skuteczna praktyczna edukacja finansowa to przygotowanie człowieka do jego i rodzinnych, i zawodowych potrzeb oraz okoliczności szybko zmieniających się uwarunkowań społecznych i gospodarczych, dlatego powinna być ona realizowana na wszystkich etapach jego życia (Solarz 2018).

Z punktu widzenia finansowego już samo prowadzenie gospodarstwa domowego jest sprawą niezmiernie istotną, ponieważ budowanie strategii rozwoju ekonomicznego rodziny ma ogromne znaczenie nie tylko dla poszczególnych osób, ale także dla pomyślnego rozwoju całego kraju. Natomiast osoby, które myślą z pewną perspektywą o ukształtowaniu czy to przyszłych przedsiębiorców, czy sukcesorów w firmach rodzinnych, ale też w przedsiębiorstwach publicznych i prywatnych $u$ innych właścicieli, muszą pamiętać o znaczeniu wykształcenia wielu kompetencji. Są to umiejętności zarówno finansowe jak i zarządcze oraz 
zdolności korzystania z różnych możliwości, jakie wiążą się z wspieraniem przez państwo finansowania rozwoju, inżynierią finansową, systemami rozliczeniowymi czy stosowaniem nowych technologii.

\section{Aktywność przedsiębiorców w Polsce}

Warto przy tym pamiętać, że polska przedsiębiorczość jest bardzo mocno zróżnicowana. Dziś jest ona zdominowana przez ponad 2,1 mln mikroprzedsiębiorstw funkcjonujących w różnych sferach działalności gospodarczej, przede wszystkim handlu, drobnej wytwórczości, ale także usług w bardzo wielu dziedzinach (PARP 2018) - Rys. 2. Przedsiębiorczość ta w naturalny sposób podlega ciągłej transformacji. Ważnym jej elementem jest wiedza ekonomiczna, która, oczywiście poza wiedzą profesjonalną, ma ogromny wpływ dla znalezienia możliwości sprzedaży produktów i usług na rynku krajowym, ale też ich eksportu do krajów UE czy na rynki pozaeuropejskie. To z kolei ma strategiczne znaczenie dla rozwoju samych firm, a w konsekwencji całej narodowej gospodarki. Pamiętajmy, że eksport towarów polskich przedsiębiorców w okresie od stycznia do sierpnia 2018 r. przekraczał 145 mld euro (Stowarzyszenie Eksporterów Polskich 2018) i stanowi bardzo ważny komponent polskiego PKB. Umiejętne znalezienie się na rynkach zagranicznych, chociażby w ramach Unii Europejskiej, wymaga bardzo wielu różnych umiejętności od kadry kierowniczej i właścicieli polskich firm. Polskę na tle innych krajów europejskich cechuje duży odsetek osób pracujących na własny rachunek oraz liczby podmiotów gospodarczych na 10 tys. ludności (Rys. 3). Świadczy to o dużym potencjale polskiej przedsiębiorczości i wskazuje na duże potencjalne możliwości ekspansji na rynki zagraniczne, szczególnie w ramach UE. Należy też podkreślić duży udział polskich przedsiębiorstw w tworzeniu PKB, wynoszący w 2016 r. ponad 34 proc. (Rys. 4).

Rys. 2. Liczba przedsiębiorstw aktywnych w Polsce w latach 2008-2016 (w tys.)

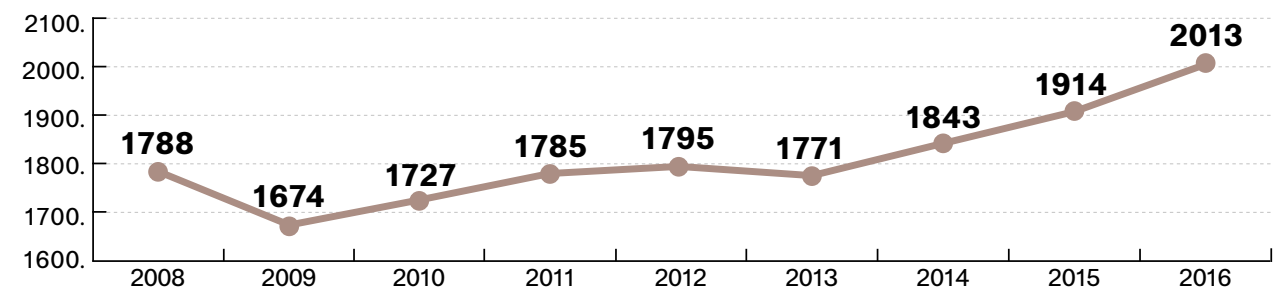

Źródło: Polska Agencja Rozwoju Przedsiębiorczości, „Raport o stanie małych i średnich firm w Polsce”, 2018 
Rys. 3. Udział pracujących na własny rachunek w ogólnej liczbie racujących w gospodarce w 2016 r.

(A) oraz liczba przedsiębiorstw niefinansowych na 10 tys. mieszkańców w 2015 r. (B) w krajach UE

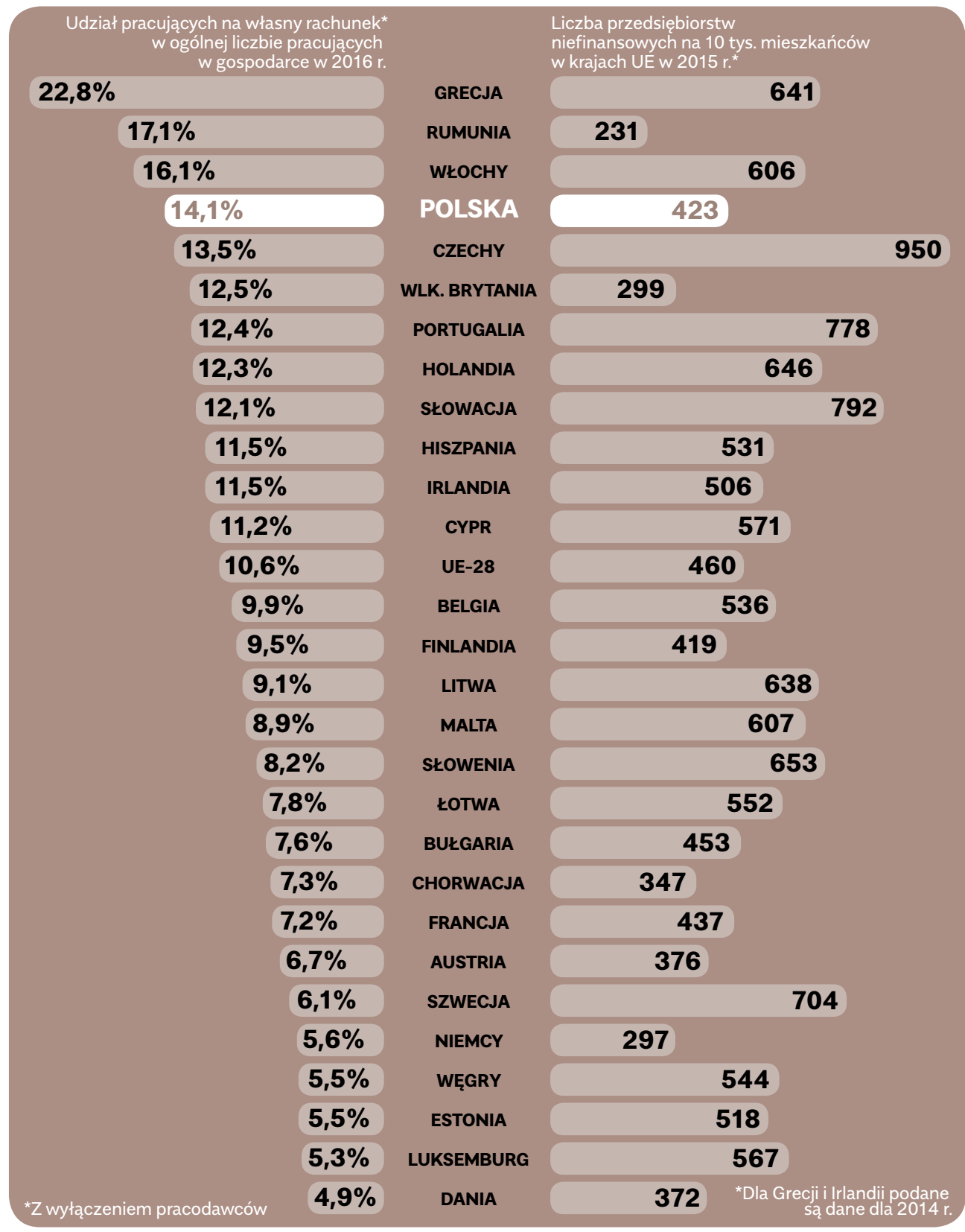

Źródło: Opracowanie własne na podstawie raportu Ernst\&Young, „Polskie przedsiębiorstwa wczoraj i dziś", 2017 


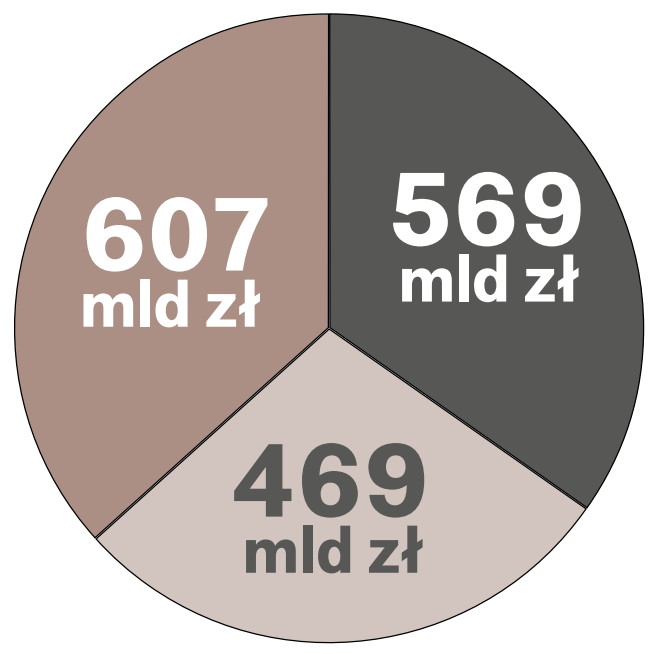

polscy przedsiębiorcy

pozostałe przedsiębiorstwa

państwo i inne części gospodarki

Źródło: Polityka Insight, Polska Rada Biznesu, „Raport Przedsiębiorca odczarowany”, 2018

\section{Wiedza w zakresie pozyskania środków}

\section{finansowania działalności}

Działania w zakresie podnoszenia konkurencyjności na rynku krajowym czy ekspansji na rynki zagraniczne wymagają jednak od przedsiębiorców posiadania odpowiedniej wiedzy w zakresie zdobywania środków finansowych, w tym środków unijnych. Jak wskazują jednak wyniki badań wśród małych i średnich firm, ich samoocena wskazuje na ciągle niewystarczającą wiedzę na ten temat (Związek Banków Polskich i Indicator 2018). Wyraźnie jest też widoczna prawidłowość, że poziom wiedzy w zakresie pozyskiwania środków UE wśród małych firm jest niższy niż wśród firm średniej wielkości (Rys. 5). 
Rys. 5 Samoocena wiedzy w zakresie pozyskiwania środków UE przez małe i średnie przedsiębiorstwa

Jak Pan(i) ocenia swój poziom wiedzy w poszczególnych obszarach związanych z pozyskiwaniem środków z funduszy unijnych w nowej perspektywie 2014-2020?

\section{MAKE FIRMY}

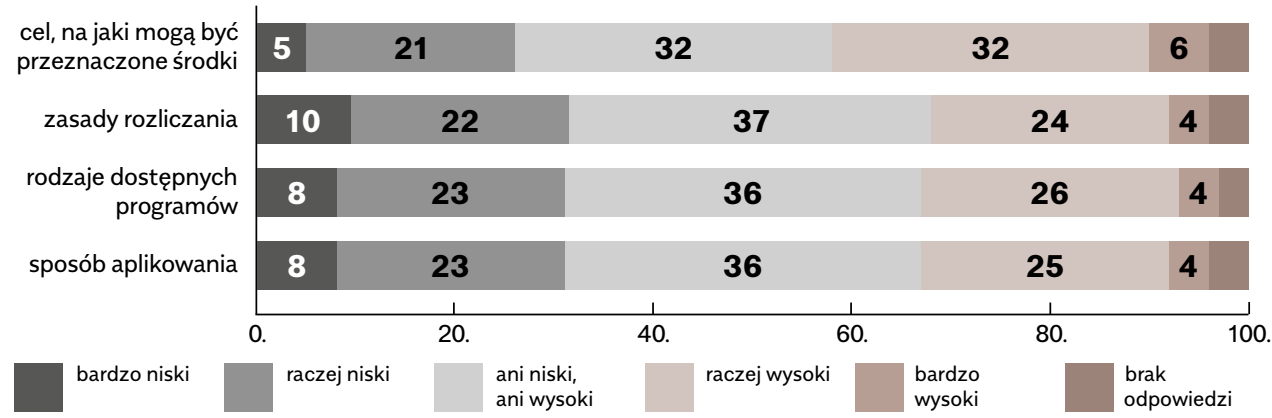

\section{ŚREDNIE FIRMY}

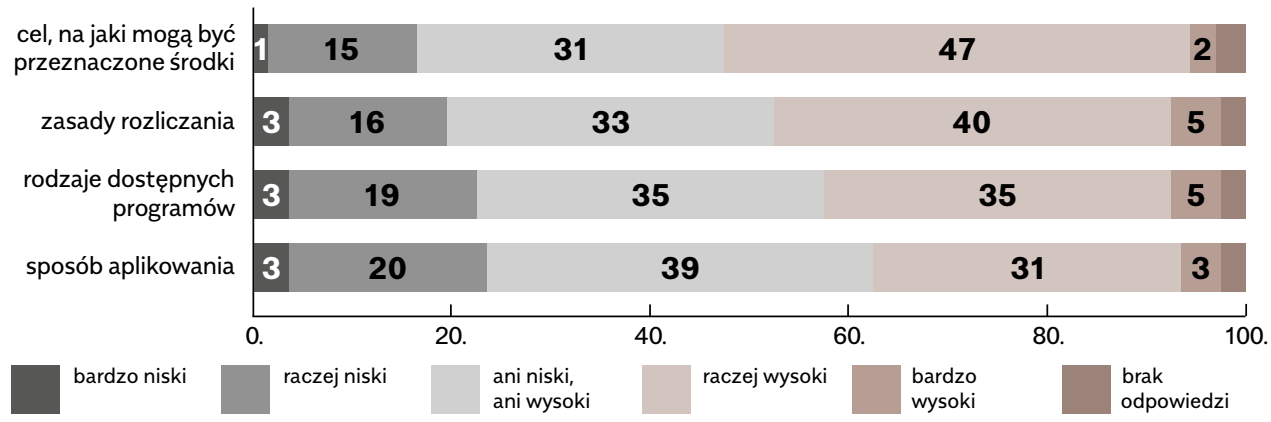

Źródło: Raport Związku Banków Polskich i Indicator, „Mikro, małe i średnie przedsiębiorstwa o usługach finansowych", 2018

W przypadku przedsiębiorstw należy też pamiętać o czysto praktycznych aspektach. Po pierwsze do właściwej komunikacji przedsiębiorstwa z otoczeniem potrzebne są umiejętności tworzenia programów rozwojowych, planów i modeli biznesowych. Po drugie do komunikowania się z innymi partnerami gospodarczymi czy wierzycielami przydatne są konkretne umiejętności formowania poprawnych ocen, przewidywania ale też budowania i przedstawiania przekonywujących strategii rozwojowych. Taka wiedza jest również potrzebna przynajmniej na po- 
ziomie elementarnym, kiedy chcemy korzystać z usług konsultantów po to, aby jasno zdefiniować oczekiwania i posiadać zdolność ocen przedstawionych opracowań i propozycji działania. Z kolei po trzecie, prowadzenie przedsiębiorstwa w warunkach niepewności, wymaga i w kolejnych latach wymagać będzie rozumienia podstawowych związków makroekonomicznych - inflacji, planów i projektów budżetowych rządu, komunikatów banków centralnych, kiedy mowa jest o polityce monetarnej czy rozumienia sygnałów jakie płyną ze strony rządowej czy samorządowej, gdy chodzi o politykę fiskalną i strategię rozwoju kraju oraz rozwoju regionalnego (Koźmiński 2005).

Szczególną w polskiej gospodarce uwagę należy zwracać na problemy restrukturyzacji i sukcesji. Z jednej strony w żywym organizmie gospodarczym okresowa modernizacja działania firmy lub nawet głębsza restrukturyzacja bywa zwykłą koniecznością i wymaga odpowiednich kompetencji i działań. Z drugiej strony, bardzo często źle przygotowana sukcesja, podejmowana w ostatniej chwili prowadzi do poważnych perturbacji i niepotrzebnych strat (Macieja 1990, Malesa 2015). Jest to szczególnie ważny problem w przypadku polskich firm rodzinnych, dlatego jak wskazuje m.in. R. Sobiecki (2010) problematyka ta powinna być więc nieodłącznym elementem edukacji ekonomicznej przedsiębiorców.

Nie ulega wątpliwości, że skuteczne prowadzenie przedsiębiorstwa, szczególnie średniej, ale i dużej wielkości bez solidnej wiedzy makroekonomicznej i znajomości instrumentów finansowych jest dziś niemożliwe. Dla rozwoju działalności gospodarczej konieczne jest przecież skorzystanie z kredytu, gwarancji, a przy zawieraniu kontraktów zagranicznych istnieje potrzeba zastosowania instrumentów zabezpieczających lub użycia odpowiednich instrumentów w rozliczeniach transgranicznych. Brak tego typu wiedzy i rozeznania może skutkować kosztownymi pomyłkami i zaniechaniami, które w wyniku niewłaściwego sformułowania umów czy złego doboru instrumentów, jakie właściwemu rozwojowi firmy powinny służyć, może w skrajnej sytuacji doprowadzić firmę do upadku (PARP 2018).

Warto również dostrzec rosnącą rolę finansów w sferze ochrony środowiska. O znaczeniu tego zagadnienia najlepiej świadczą, przyznane w ostatnich latach, Nagrody Nobla w dziedzinie ekonomii. Z jednej strony dotyczyły one stosowania nowych technologii, a z drugiej zaś punktów stycznych ekonomii i właśnie ochrony środowiska. To pokazuje, że od przedsiębiorcy będzie trzeba wymagać pewnego rozumie- 
nia konsekwencji działalności gospodarczej, związanej z ingerencją w środowisko przyrodnicze, a także stosowania nowych technologii, również w zakresie ochrony środowiska. W związku z tym nowoczesny przedsiębiorca musi rozumieć bardzo dobrze w jakim kierunku zmierza współczesny świat. Mowa tu przede wszystkim o ta takich kwestiach, jak sukcesywna automatyzacja procesów produkcyjnych i usług, stosowanie sztucznej inteligencji, czy robotyzacja na większą skalę. I nie chodzi tylko o zastosowanie tych metod we własnej firmie, ale także o stosowanie ich przez konkurentów i partnerów gospodarczych jako sposobu zdobywania przewagi na rynku. Dobrze zilustrowano to zagadnienie we wspomnianym wcześniej raporcie „Potencjał automatyzacji gospodarki w perspektywie roku 2030" opublikowanym w 2018 r. przez McKinsey i Forbesa.

Współczesny przedsiębiorca, w dobie programów rozwojowych realizowanych w Unii Europejskiej, programów sektorowych czy wspólnotowych, musi posiadać zdolność oceny wpływu tych inicjatyw na biznes, ale także rozumienia możliwości i konsekwencji korzystania z nich, ponieważ od tego może zależeć pomyślny rozwój jego przedsiębiorstwa. W systemach finansowania rozwoju, poza subwencjami, jakie były przyznawane w ostatnich latach na rozwój przedsiębiorstw, stosowane są na dużą skalę gwarancje i poręczenia, specjalne programy wspierające wdrażanie innowacji, czy też instrumenty wspierające transfer technologii z ośrodków naukowo-badawczych do przemysłu. Realizowane są też coraz szerzej programy związane z ochroną środowiska, termomodernizacją, wytwarzaniem energii ze źródeł odnawialnych i kilka nowych programów z obszaru ekonomii kreatywnej. Musimy pamiętać, że przedsiębiorca to jest ktoś kto wytwarza użyteczny, przydatny produkt lub usługę i potrafi wykonać usługę lub dzieło, które spotka się z uznaniem nabywców (Pekao 2017).

Przedsiębiorca to ktoś, kto powinien potrafić skojarzyć potrzeby klientów indywidualnych czy instytucjonalnych z możliwościami wytwórczymi i własnymi ideami, które mogą prowadzić do przygotowania atrakcyjnego rozwiązania w postaci produktów i usług. Aby takie możliwości posiadać, potrzebna jest gruntowna wiedza, zarówno w określonej dziedzinie, jak np. w zakresie ochrony środowiska, rolnictwa, przemysłu maszynowego i samochodowego, logistyki czy transportu, połączona z fachową wiedzą finansową przynajmniej na poziomie podstawowym, bo ostatecznie koncepcja jaką przedsiębiorca chce realizować musi 
być ujęta w pewien zestaw symulacji, rachunków i ocen. Ma to ogromne znaczenie dla wiarygodności kształtowanych planów, ale także dla monitorowania procesów rozwojowych, w którym to procesie często uczestniczą nie tylko sami prywatni inwestorzy czy właściciele firm, ale także wierzyciele w postaci banków, firm poręczeniowo-gwarancyjnych, firm typu venture capital czy funduszy inwestycyjnych. Rozwój przedsiębiorczości zależy od zdolności właścicieli i kadry zarządzającej do budowania i efektywnego wykorzystania kapitału społecznego oraz dbania o korzystne kształtowanie dobrostanu psychicznego obywateli w środowisku działania (Growiec 2015).

Dlatego też, dla osiągania celów rozwojowych firm, społeczności lokalnych oraz kraju konieczne jest opracowanie i wdrożenie atrakcyjnych i dobrych jakościowo programów edukacji finansowej oraz z zakresu zarządzania odpowiednio dostosowanych do wieku dzieci i młodzieży. Powinny być one realizowane na wszystkich poziomach szkolnictwa. Niezależnie od systemu edukacji szkolnej należy zadbać o stałe uzupełnianie wiedzy ekonomicznej przedsiębiorców. Wymaga tego intensywność i zakres zmian zachodzących we współczesnym świecie.

Stan wiedzy ekonomicznej Polaków i deficyty w tym zakresie przedstawiają raporty, które są uwzględniane przy opracowywaniu "Mapy edukacji finansowej" (Czernek i in. 2017). Wnioski z opracowywanych raportów stanowią podstawę do podejmowanych przez środowisko finansowe działań w zakresie kształtowania podstaw programowych ustalanych przez Ministerstwo Edukacji Narodowej oraz sektorowych kampanii edukacyjnych prowadzonych przez m.in. Związek Banków Polskich i Warszawski Instytut Bankowości, wspólnie ze szkołami oraz wieloma instytucjami finansowymi i samorządowymi.

\section{Podsumowanie}

Warto zastanowić się, jaki tak naprawdę jest dziś obraz polskiego przedsiębiorcy. Z pewnością jest on nie tylko osobą zarządzającą, ale także coraz lepiej wykształconym pracodawcą i fundatorem. Polski przedsiębiorca ponosi także znaczne nakłady na prace modernizacyjne i rozwojowe, choć ciągle mniejsze, niż konkurenci w wielu krajach UE. Polski przedsiębiorca nierzadko prowadzi kilka firm równocześnie (Polityka Insight, Polska Rada Biznesu 2018). Nie ulega wątpliwości, że przedsiębiorca lepiej wykształcony, częściej osiąga sukces gospodarczy, łatwiej podejmuje decyzje o stosowaniu innowacyjnych rozwiązań oraz 
osiąga wyższe dochody niż osoby słabiej wykształcone (PARP 2018). Wyniki badań prowadzonych w poszczególnych uczelniach oraz przez ogólnopolski system monitorowania Ekonomicznych Losów Absolwentów wskazują na to, że osoby kończące najlepsze polskie uczelnie nie mają żadnych lub większych problemów ze znalezieniem pracy. Ich wynagrodzenia zwykle są wyższe, a wielu z nich szybciej niż inni absolwenci obejmują stanowiska kierownicze w przedsiębiorstwach. Stąd, płyną jednoznaczne i uprawnione wnioski mówiące o tym, że solidne kształcenie na poziomie średnim i wyższym oraz systematyczne dokształcanie w okresie pracy zawodowej wpływają pozytywnie na rozwój przedsiębiorczości, chęć pozostania przedsiębiorcą oraz losy przedsiębiorców (Kudełka, Lasek 2014). 


\section{Bibliografia}

$\rightarrow$ Cieślik, J. (2010), Przedsiębiorczość dla ambitnych. Warszawa: Wydawnictwa Akademickie i Profesjonalne.

$\rightarrow$ Czernek, K., Jurek, M., Marszałek, P. (2017), Mapa Edukacji Finansowej, VI edycja, Poznań: Związek Banków Polskich.

$\rightarrow$ Ernst\&Young (2017), Polskie przedsiębiorstwa wczoraj i dziś. Raport.

$\rightarrow$ Growiec, K. (2015), lle szczęścia dajq nam inni ludzie. Więzi społeczne a dobrostan psychiczny, Warszawa: Wydawnictwo Naukowe PWN.

$\rightarrow$ Koźmiński, A. (2005), Zarzq̨dzanie w warunkach niepewności, Warszawa: Wydawnictwo Naukowe PWN.

$\rightarrow$ Kudełka, M., Lasek, M. (2014), Przedsiębiorca. Kto nim zostaje? Próba analizy za pomocą modelu regresji logistycznej, „Ekonomia i Zarządzanie”, nr 1, s. 220-237.

$\rightarrow$ Kwiatkowski, S. (2000), „Przedsiębiorca intelektualny”, Warszawa: Wydawnictwo Naukowe PWN.

$\rightarrow$ Lichtarski J. (red.) (2005), Podstawy nauki o przedsiębiorstwie, Wrocław: Wydawnictwo Akademii Ekonomicznej we Wrocławiu.

$\rightarrow$ Macieja, J. (1990), Przedsiębiorczość w systemie ekonomicznym, „Studia Ekonomiczne Instytutu Nauk Ekonomicznych PAN", nr 24.

$\rightarrow$ Malesa, T. (2015), Sukcesja $w$ firmie rodzinnej - droga do rozwoju czy upadku. Studium przypadku, „Studia i Materiały Wydziału Zarządzania”. Uniwersytet Warszawski, nr 1, s. 83-97.

$\rightarrow$ Noga, A. (2009), Teorie przedsiębiorstw, Warszawa: PWE.

$\rightarrow$ Sobiecki, R. (2010), Jak uczyć przedsiębiorców: na podstawie przedsiębiorczości rodzinnej, "Kwartalnik Nauk o Przedsiębiorstwie”, nr 3, s. 32-39.

$\rightarrow$ Solarz, J.K. i in. (2018), Całościowa edukacja finansowa - teoria i praktyka, Łódź: Wydawnictwo Społecznej Akademii Nauk.

$\rightarrow$ Stowarzyszenie Eksporterów Polskich (2018), Raport okresowy za wrzesień 2018. 


\section{Netografia}

$\rightarrow$ McKinsey\&Company/Forbes (2018), Raport "Ramię w ramię z robotem. Jak wykorzystać potencjał automatyzacji w Polsce", mckinsey.pl/wp-content/ uploads/2018/05/Rami\%C4\%99-w-rami\%C4\%99-z-robotem_Raport-McKinsey.pdf (dostęp: 25.02.2019).

$\rightarrow$ Pekao SA (2017), "Raport o stanie mikro i małych firm w Polsce”, www.pekao. com.pl/male-i-srednie-firmy/raport.html (dostęp: 25.02.2019).

$\rightarrow$ Polityka Insight, Polska Rada Biznesu (2018), „Raport Przedsiębiorca odczarowany", prb.pl/wp-content/uploads/2018/05/Przedsiebiorca-odczarowany.pdf (dostęp: 25.02.2019).

$\rightarrow$ Polska Agencja Rozwoju Przedsiębiorczości (2018), „Raport o stanie małych i średnich firm w Polsce", www.parp.gov.pl/component/publications/publication/ male-i-srednie-przedsiebiorstwa-w-polsce-w-2018-r (dostęp: 25.02.2019). 


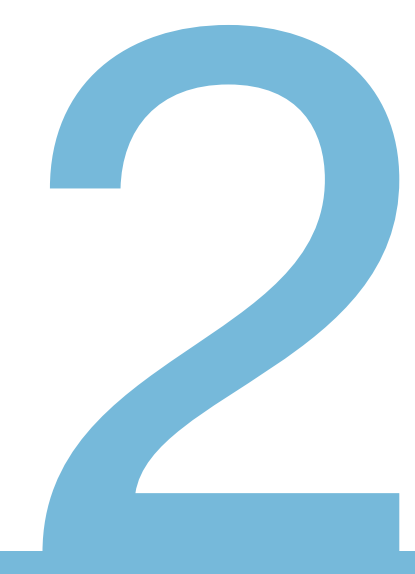




\section{Ksztaltowanie kompetencji przedsiębiorczych w edukacji}




\title{
Etyka korczakowska a duch przedsiębiorczości
}

\author{
Wojciech Lasota
}

Tekst jest próbą wycinkowej rekonstrukcji korczakowskiego rozumienia pojęcia przedsiębiorczości, którego Janusz Korczak ściśle nie zdefiniował. Pokazany jest w nim związek między korczakowskim pojmowaniem przedsiębiorczości a ważnymi dla Korczaka wartościami moralnymi: podmiotowością i etyką pracy. Autor stawia tezę, że instytucje korczakowskie sprzyjały rozwijaniu przedsiębiorczości wśród wychowanków oraz popiera tę tezę przykładami odnoszącymi się do historii Domu Sierot.

\section{Słowa kluczowe:}

\section{przedsiębiorczość}

podmiotowość

etyka

etyka pracy

Janusz Korczak

Max Weber 


\section{The Janusz Korczalk's ethics and the spirit of entrepreneurship}

Wojciech Lasota

The text is an attempt of the fragmentary reconstruction of the Janusz Korczak's concept of entrepreneurship which Janusz Korczak did not define strictly. It shows the connection between Korczak's understanding of entrepreneurship and the moral values important for him: subjectivity and work ethics. The author puts forward the thesis that the Korczak institutions favoured the development of entrepreneurship among foster children. This thesis is supported by examples referring to the history of the Orphans' Home.

\section{Keywords:}

\section{entrepreneurship \\ subjectivity \\ ethics \\ work ethics \\ Janusz Korczak \\ Max Weber}




\section{Wstęp}

W swojej słynnej pracy Etyka protestancka a duch kapitalizmu Max Weber (2011) wskazywał istnienie związku między etycznymi postawami, obecnymi w społeczeństwach protestanckich, a prężnym rozwojem pewnego rodzaju kapitalizmu w tych społeczeństwach. Niniejszy tekst ukazuje podobny związek, choć w dużo mniejszej skali: między etycznymi wskazaniami obecnymi w pismach i praktyce Janusza Korczaka a efektami oddziaływania tych wskazań w obszarze swoiście pojmowanej przedsiębiorczości wśród osób, które ich doświadczyły jako wychowankowie Domu Sierot.

Najważniejsza teza artykułu brzmi: jeśli przyjąć jako zasadniczą wartość etyczną traktowanie ludzi z szacunkiem dla ich podmiotowości (by tak skrótowo na razie oddać podejście Korczaka) i zgodnie z tą wartością postępować oraz wpływać na innych ludzi, to możliwe jest przez to zwiększenie możliwości rozwijania przez nich różnorakich kompetencji przedsiębiorczych.

\section{Między Weberem a Korczakiem}

Wyjaśniając pojęcie "ducha kapitalizmu", Weber odwołuje się do pism i osoby Benjamina Franklina, uosabiających owego ducha. Omawiając główną tezę książki, czyli uzasadnioną religijnie motywację protestantów do zarabiania pieniędzy, pisze: „Na pytanie: d l a c z e g o «z ludzi powinniśmy robić pieniądze», Benjamin Franklin, choć sam niezwiązany z żadnym wyznaniem deista, odpowiada w swym Żywocie własnym biblijnym cytatem, który jak powiada, jego rygorystycznie kalwiński ojciec starał mu się wbić w pamięć w młodości: «Widzisz biegłego w s w o i m z a wo d z i e? Będzie on stał przed obliczem królów». Zarabianie pieniędzy jest - o ile odbywa się $w$ legalny sposób - w ramach nowoczesnego porządku gospodarczego rezultatem i wyrazem zdatności w z a w o d z i e i ta zdatność, co rzuca się w oczy, jest prawdziwą alfą i omegą moralności Franklina, objawiającej się zarówno w cytowanym tu fragmencie, jak i we wszystkich jego pismach bez wyjątku" (Weber 2011, s. 78).

Ogromna ważność „zdatności w zawodzie" jest również „alfą i omegą moralności" Korczaka, z jedną zasadniczą różnicą. Dla Franklina sprawdzianem zdatności są pieniądze. Ma ona charakter ściśle zewnętrzny, a ponieważ relacja zdatności z jej finansowym wymiarem zależy od wielu czynników ekonomicznych, społecznych i kulturowych, jest wystawiana - mówiąc metaforycznie - na swoistą codzienną giełdę, na 
której jednostki notują wzrosty i spadki jej wartości. Dla Korczaka wymiar finansowy łączy się z wykonywanym zawodem, ale nie z jakością "zdatności w zawodzie". Ma ona dla niego charakter wewnętrzny i jednostka ma na nią duży wpływ. Jeśli człowiek jest gotów wciąż doskonalić jakość swojej pracy oraz jakość dokonywanej nad nią refleksji, wówczas wysokie poczucie jego zdatności jest w pełni usprawiedliwione, niezależnie od tego, jaką i jak dobrze płatną pracę wykonuje.

llustrują to fragmenty pisanego w getcie warszawskim tekstu Dlaczego zbieram naczynia?, który można uznać za modelowy wyraz tego podejścia. Korczak tłumaczy w nim, dlaczego po posiłkach w Domu Sierot zbiera naczynia, choć nie jest to jego obowiązek: „Kiedy zbieram sam, widzę pęknięte talerze, widzę zgięte łyżki, podrapane miseczki. [...] Czasem zerknę, jak rozdaje się dodatki, albo zobaczę, kto przy kim siedzi - i pomyślę sobie o tym i owym. - Bo kiedy coś robię, to nigdy bezmyślnie [wyróżnienie autora]. Ta praca kelnera jest dla mnie i pożyteczna, i miła, i ciekawa. Ale nie to jest ważne. Ważne jest zgoła coś innego. Coś, o czym wiele razy już mówiłem i pisałem, i z czym walczę od lat trzydziestu, od czasu, jak powstał Dom Sierot - walczę bez nadziei zwycięstwa, bez widocznego skutku, ale walki tej przerwać nie chcę i nie mogę.

$\mathrm{O}$ to walczę, aby w Domu Sierot nie było roboty delikatnej czy ordynarnej, mądrej czy głupiej, czystej czy brudnej - roboty dla panieneczek i zwyczajnej hołoty. Nie powinno być w Domu Sierot pracowników wyłącznie fizycznych i wyłącznie umysłowych. Ze zgorszeniem i z niesmakiem patrzą w magistrackim internacie na Dzielnej, że podaję rękę posługaczce, i to nawet wtedy, kiedy myje schody i ma mokre ręce. [...]

Szanuję uczciwych pracowników. Ręce ich są dla mnie czyste i zdanie ich ważę na wagę złota. Praczka i stróż bywali na Krochmalnej nie dlatego, żeby im sprawić przyjemność, ale żeby jako znawcy poradzili i pomogli [...].

Ordynarna inkasentka jest dla mnie chamem i pętakiem. Pan Lejzor jest pięknym człowiekiem, choć grzebie się w nieczystościach rur i kanałów. Panna Nacia, gdyby obierała kartofle, byłaby dla mnie równie godna szacunku jak teraz, kiedy pisze na maszynie" (Korczak 1958, s. 592-593).

\section{Duch przedsiębiorczości}

W zaleceniach Rady Unii Europejskiej z dnia 22 maja 2018 r. w sprawie kompetencji kluczowych w procesie uczenia się przez całe życie widnieje 
następujące określenie kompetencji przedsiębiorczych: „Kompetencje w zakresie przedsiębiorczości to między innymi zdolność wykorzystywania szans i pomysłów oraz przekształcania ich w wartość dla innych osób. [...] Obejmują one zdolność pracy samodzielnej i zespołowej, mobilizowania zasobów (ludzi i przedmiotów) oraz prowadzenia działalności gospodarczej" (Zalecenie Rady Unii Europejskiej 2018, s. 11). Widoczna powyżej wielość kompetencji oraz możliwych sposobów ich zastosowania powoduje, że zasadne wydaje się użycie pojęcia "duch przedsiębiorczości" w znaczeniu pewnej dość nieuchwytnej postawy, która jednak bardzo konkretnie może manifestować się w bardzo różnych sytuacjach.

W podobny sposób ujmował Korczak siłę wpływu, który jego zdaniem kształtuje postawy w rodzinach, pisząc o "terenach wychowawczych": „Terenem wychowawczym nazywam duszę rodziny, która panuje, poszczególni członkowie nie mogą zajmować względem niej stanowiska dowolnego. Ta dusza kierująca zmusza, nie znosi oporu" (Korczak 2012, s. 78).

\section{Podmiotowość w etyce korczakowskiej}

Najbardziej doniosłym ze wskazań etycznych Korczaka jest imperatyw zrównania ważności egzystencji dziecka z życiem dorosłego. Przewija się on przez całą jego twórczość. Już w 1899 r., a więc jako 20-latek, pisze: „Dzieci nie będą dopiero, ale są już ludźmi, tak, ludźmi są, a nie lalkami" (Korczak 1983, s. 31). 40 lat później ujmuje to tak: „Myśl przewodnia: dziecko jest równo nam wartościowym człowiekiem" (Korczak 1939, s. 5).

Najtrafniejszym określeniem tego, czego domagał się uparcie Janusz Korczak, jest uznanie godności, rozumianej jako prawo do posiadania praw oraz korzystania $z$ nich, wynikające wyłącznie $z$ faktu bycia istotą ludzką.

Niepodobna jednak, zdaniem Korczaka, oddzielić bycia człowiekiem od korzystania z tego faktu w działaniu, na rzecz własną i czyjąś. Właśnie dlatego naczelną wartością dla Janusza Korczaka wydaje się podmiotowość istoty ludzkiej ( $w$ tym dziecka, ale nie tylko jego), jakkolwiek on sam nie używał tego pojęcia. Pojęcie podmiotowości w kontekście myśli i praktyki korczakowskiej można rozumieć jako "poczucie i możliwość intencjonalnego, realnego wpływu na siebie i otoczenie" (Lasota 2017, s. 14). Inne Korczakowskie wska- 
zania moralne są właśnie pochodną respektowania przez niego podmiotowości.

\section{Korczakowska przedsiębiorczość}

W rozumieniu przedsiębiorczości według Korczaka wyróżnić można następujące elementy: intencję, proces oraz efekt użytku, który w określonych warunkach robi człowiek (również dziecko) ze swoich sił, zasobów i talentów.

Intencja kieruje poczynaniami. Sam o sobie pisał Korczak w tym kontekście: „pracowałem wtedy tylko, kiedy wierzyłem, że praca przynosi pożytek" (Korczak 2008, s. 221). Ta wiara mniej związana jest z tym, co się robi, a bardziej z tym, jak to się robi, kluczowym pojęciem jest tu zaś „pożytek”. Przyglądając się efektom działań, można sprawdzić, na ile intencje działania dla pożytku wcielone zostały w czyn. Obszar owego pożytku jest mniej istotny.

Dla Korczaka praca dla dobra wspólnego była wartością ogromną: „Żyłeś? Ile przeorałeś? Ile wypiekłeś chlebów dla ludzi? Ile zasiałeś? Zasadziłeś drzew? lle ułożyłeś cegieł pod budowę, zanim odejdziesz? [...] Komu i ile ciepła? Jaka była twoja służba? Jakie nagłówki rozdziałów twej drogi?" (Korczak 1986, s. 299). Jednocześnie jednak niezwykle ważna jest dla niego samowiedza i troska o jakość jednostkowego życia. Pisał w liście do Józefa Arnona: „[...] każdy człowiek i somatycznie, i duchowo jest wszechświatem, i kto by umiejętnie kierował tylko samym sobą, ten też spełniłby swoje zadanie; żyjemy pośpiesznie, niedbale, powierzchownie, partacko" (Korczak 2008, s. 234).

Przedsiębiorczość lokuje się dla Korczaka przede wszystkim w procesie przekuwania intencji na czyn, a czynu na efekt. Jest to przy tym zawsze przedsiębiorczość na dwóch poziomach.

Pierwszy poziom jest związany z odpowiedzią na pytanie, na ile sprawnie zostały wykorzystane zasoby, umiejętności czy sieci społeczne, by realizować działania i doprowadzać je do końca. Czy zaangażowane osoby potrafią myśleć, rozmawiać, negocjować, liczyć, przekonywać, ale też wycofywać się, zmieniać plany i godzić się na kompromisy.

Poziom drugi jest związany z odpowiedzią na pytanie, na ile ta sprawność działania wciąż pozostaje etyczna. Skąd wiadomo, że nadal służy ona czyjemuś pożytkowi? Czy pojawia się wola dostrzeżenia, że efekty naszych działań nie są spójne z początkowymi intencjami? Kiedy uruchamiana jest przedsiębiorczość na tym poziomie, działające $w$ taki 
sposób osoby korzystają z zasobów, umiejętności czy sieci społecznych, by korygować swoje działania zgodnie z ich wartościami etycznymi.

\section{Oddziaływanie etyki korczakowskiej}

Czy można zaryzykować tezę, że dzieci, które doświadczyły oddziaływania instytucji korczakowskich, były wychowywane w duchu przedsiębiorczości? I czy rozumienie tej przedsiębiorczości bliskie jest tego, które znajduje się w przywoływanych już zaleceniach Rady Unii Europejskiej?

Zgodnie z naszą wiedzą o sposobie funkcjonowania Domu Sierot na powyższe pytania należy odpowiedzieć twierdząco. W następnych trzech podrozdziałach znajdują się odwołania do historii Domu Sierot, które wskazują na to, że wychowywane tam dzieci:

$\rightarrow$ miały „zdolność wykorzystywania szans i pomysłów oraz przekształcania ich w wartość dla innych osób" (Zalecenie Rady Unii Europejskiej 2018, s. 11);

$\rightarrow$ były kreatywne, wytrwałe, myślały krytycznie oraz rozwiązywały problemy, podejmowały inicjatywę i miały „zdolności do wspólnego działania służącego planowaniu projektów mających wartość kulturalną, społeczną lub finansową" (tamże);

$\rightarrow$ potrafiły „przekształcać pomysły w działanie w sferze osobistej, społecznej i zawodowej" (tamże), a także rozumiały procesy ich powstawania.

\section{Statystyki Domu Sierot}

W roku 1933, w 25-lecie działalności Towarzystwa "Pomoc dla Sierot”, które zawiadywało Domem Sierot, Korczak liczbowo zobrazował aktywność Domu Sierot od roku 1912. Wszystkich wychowanków było 455, z tego 36 osób było w Domu Sierot krócej niż rok, a o dalszych 38 nie miał informacji. 50 osób emigrowało, najwięcej do USA oraz do Belgii, Francji, Anglii i Palestyny. O pozostałych pisze Korczak: „Bieliźniarek - 3. Biuralistek - 8. Ekspedientek (w sklepach - 15). Freblanek - 5. Fryzjerek - 3. Gorseciarek - 5. [...] W szkołach - 9. Wychowawczyń w instytucjach społecznych - 4. Biuralistów - 12. Drukarzy - 4. Ekspedientów - 11. Elektrotechników - 3. Fryzjerów - 9. Gońców - 10. [...] Pozostali różnie: czapnik, dorożkarz, fotograf, malarz, muzyk, optyk, rymarz, rzeźnik, tapicer, technik budowlany. Grzebienie, galanteria, manikiurzystka, nauczyciel tańca" (Korczak 2008a, s. 144). 
W sumie minimum 133 zatrudnione lub uczące się kobiety i 108 mężczyzn, łącznie ponad 241 osób. Oznacza to, że zdecydowanie ponad połowa wychowanków i wychowanek Domu Sierot była w stanie wykształcić się w zawodzie, a następnie znaleźć i utrzymać zatrudnienie na trudnym, pokryzysowym rynku pracy. Korczak do tego zestawienia dopisał jeszcze: „Chwila wahania - wreszcie na 455 - 2 żebraków, 2 prostytutki, 3 za kradzieże sądzeni. Ten zrozumie, kto przeżył" (tamże, s. 144). Oznacza to, że tylko siedem na ponad 450 osób, które w ciągu 25 lat były wychowywane w Domu Sierot, znalazło się w konflikcie z prawem.

\section{List z Argentyny}

Został on opublikowany w sprawozdaniu Towarzystwa "Pomoc dla Sierot" za 1931 r. Autorem jest były wychowanek Domu Sierot o nieznanym nam imieniu i nazwisku, który przymiera głodem w Argentynie, szukając pracy. W 1931 r. niespodziewanie spotyka tam innego wychowanka, Dawida: „W pierwszych dniach po naszym spotkaniu żyliśmy w wielkiej zgodzie, ale potem zaczęły się ujawniać wady jego i moje, a więc - kłótnie. Zaczęliśmy się zastanawiać, co robić, by zaprzestać się kłócić. Oto cośmy uradzili:

1. Najważniejszym bodźcem kłótni jest zły humor jednego z nas. Kiedy więc jeden jest $w$ złym humorze, a nie chce $z$ drugim rozmawiać, mówi: «Nie mów teraz do mnie» i ten «drugi» jest obowiązany nie mówić do «pierwszego" przez godzinę.

2. Kłótnie następowały także w razach, gdy miano coś uradzić, a żaden nie chciał ustąpić, wtedy mieliśmy urządzić losowanie.

3. Są spory, których nie można przeprowadzić przez losowanie, gdyż są za bardzo ważne dla naszego pobytu [...]. Wtedy się tę sprawę odkłada na kilka minut, a potem jeden mówi, dlaczego chce czy nie chce, i drugi robi to samo. Oczywiście «przemówienia stron» nie są przerywane.

Z umowy naszej skorzystaliśmy" (Korczak 2008a, s. 130).

To jeden z najdobitniejszych dowodów oddziaływania siły korczakowskich instytucji. Obaj chłopcy zyskali tam świadomą kompetencję w zakresie radzenia sobie z trudnościami. Zastosowali ją w sytuacji, w której bez odpowiednich umiejętności łatwo byłoby się dać ponieść emocjom, tendencji do wzajemnego obwiniania się czy innym destrukcyjnym impulsom. Również następne strony listu poświęcone 
są opisowi działań ściśle przedsiębiorczych, takich jak perypetie związane z szukaniem pracy, która pozwoliłaby chłopcom zarobić na noclegi i jedzenie. Najpierw pracę znalazł Dawid, potem autor listu, który w jego zakończeniu pisze następująco: „Wyjazdu mego do Argentyny absolutnie nie żałuję. Nauka życia wiele znaczy; więcej jak pieniądz i dobry byt" (tamże, s. 138).

\section{Z Warszawy do Ottawy}

Przykładem proprzedsiębiorczej siły oddziaływania Domu Sierot, który jest najbliższy potocznemu rozumieniu pojęcia przedsiębiorczości, a zarazem "duchowi kapitalizmu" w aspekcie zarabiania pieniędzy, są losy Leona Gluzmana, opisane w książce Oby im życie łatwiejsze było (Medvedeva-Nathoo 2012).

Leon Gluzman, urodzony około 1914 r., trafił do Domu Sierot po śmierci ojca w roku 1923 i opuścił go siedem lat później, kiedy wyjechał do Kanady, co było możliwe wyłącznie dzięki temu, że mieszkał tam jego wuj. Borykając się w Ottawie z wielkim kryzysem, korzystał właśnie z umiejętności i ze swoistego treningu, jaki przeszedł w Domu Sierot: „Leon, sierota, biedny jak mysz kościelna, był samoukiem, w biegu opanowywał zawód księgowego (umiejętność szybkiego uczenia się wyniósł z Domu Sierot, gdzie priorytetem było sprawne opanowanie czytania i pisania), a po otrzymaniu wymarzonego Commerce diploma [...] w 1946 roku założył własny biznes - najpierw była to skromna firma księgowa. Z czasem się rozrosła. Dziś należy do dwudziestu największych tego typu firm w Kanadzie" (Medvedeva-Nathoo 2012, s. 61-62).

Firma ta nosi nazwę GGFL Chartered Professional Accountants. GGFL od nazwisk założycieli: Ginsberg, Gluzman, Fage i Levitz¹.

Uznając tezę o kształtowaniu wśród dzieci w Domu Sierot postaw przedsiębiorczych za uzasadnioną, konieczne jest poczynienie pewnego zastrzeżenia. Z pewnością nie wszystkie dzieci mające kontakt z instytucjami korczakowskimi nabywały umiejętności przedsiębiorczych. Biorąc jednak pod uwagę, że Korczak pracował z dziećmi o ogromnych deficytach w wielu obszarach, wykazywanie kompetencji przedsiębiorczych u chociażby części z nich świadczy o tym, że w jego instytucjach panował klimat niezwykle sprzyjający rozwojowi tych kompetencji.

1. Na stronie internetowej firmy (www.ggfl.ca/why-ggfl) można zobaczyć zdjęcia założycieli oraz film nakręcony z okazji jubileuszu firmy. 


\section{Czy przedsiębiorczość po korczakowsku to nierealna wizja?}

Uściślając powyższe pytanie: Czy we współczesnym świecie sprawność przedsiębiorczego działania powinna być w zgodzie z wartościami etycznymi, w imię których działania te są podejmowane?

Mogłoby się wydawać, że to idealistyczne mrzonki. Jednakże już w 1954 r. jeden z niekwestionowanych autorytetów w dziedzinie zarządzania, Peter Drucker, pisał, że odpowiedzialności menedżerów nie można dłużej „opierać na założeniu, że osobisty interes właściciela będzie go wiódł ku dobru ogólnemu lub że interes osobisty i dobro ogółu można oddzielić, traktując jako kategorie niemające ze sobą nic wspólnego. Wręcz przeciwnie, odpowiedzialność ta wymaga dzisiaj od menedżera, by przyjął odpowiedzialność za dobro ogółu, by podporządkował swe działania normom etycznym, ograniczając swój własny interes i władzę w razie, gdyby ich egzekwowanie godziło w dobro powszechne i wolność jednostki" (Drucker 1998, s. 408).

Stanowisko Druckera, bardzo bliskie poglądom Korczaka, znajduje dziś godnych kontynuatorów, żeby wymienić jedynie Tomáša Sedláčka (zob. Sedláček 2011), ruch Humanistic Management (zob. Humanistic Management Center) czy polską koncepcję Open Eyes Economy (zob. Open Eyes Economy) i projekt "Nie nieodpowiedzialności" (zob. Nienieodpowiedzialni).

Powyższe rozważania potwierdzają tezę postawioną na początku artykułu: jeśli przyjąć za zasadniczą wartość etyczną traktowanie ludzi z szacunkiem dla ich podmiotowości i zgodnie z tą wartością postępować $z$ innymi ludźmi i na nich wpływać, to możliwe jest przez to zwiększenie możliwości rozwijania przez nich różnorakich kompetencji przedsiębiorczych.

Janusz Korczak przez dziesięciolecia prowadził instytucje, w których ludzie traktowani byli z szacunkiem dla swojej podmiotowości. Zwiększenie ich kompetencji przedsiębiorczych nie było tu samoistnym celem, ale środkiem do celu znacznie ważniejszego: umiejętności samodzielnego kształtowania przez dzieci ich życia w poczuciu własnej podmiotowości. Losy wielu wychowanek i wychowanków Korczaka pokazują, że posiedli tę umiejętność, w tym także kompetencje przedsiębiorcze. Dlatego również dziś możemy i powinniśmy w tym zakresie czerpać z bogatego dziedzictwa Janusza Korczaka. 


\section{Bibliografia}

$\rightarrow$ Drucker, P. (1998), Praktyka zarządzania, tłum. J.W. Gołębiowski, Kraków: Wydawnictwo Czytelnik, Nowoczesność, Akademia Ekonomiczna w Krakowie.

$\rightarrow$ Korczak, J. (1958), Pamiętnik [w:] Wybór pism, Warszawa: Nasza Księgarnia.

$\rightarrow$ Korczak, J. (1983), Rozwój idei miłości bliźniego w XIX wieku [w:] M. Falkowska (red.), Myśl pedagogiczna Janusza Korczaka. Nowe źródła, Warszawa: Nasza Księgarnia.

$\rightarrow$ Korczak, J. (1986), Samotność starości [w:] Pisma wybrane, t. IV, Warszawa: Nasza Księgarnia.

$\rightarrow$ Korczak, J. (2008a), Zamiast wstępu [do sprawozdania za okres 1930/31] [w:] Dzieła, t. 14/1, Warszawa: Instytut Badań Literackich.

$\rightarrow$ Korczak, J. (2008a), Losy byłych wychowańców Domu Sierot od roku 1912 do roku 1932 (Od otwarcia Domu Sierot [w:] Dzieła, t. 14/1, Warszawa: Instytut Badań Literackich.

$\rightarrow$ Korczak, J. (2008b), Do przyjaciół w Ein Harod [list z 23.05.1937 r.] [w:] Dzieła, t. 14/2, Warszawa: Instytut Badań Literackich.

$\rightarrow$ Korczak, J. (2008b), Do Józefa Arnona [list z 3.07.1938 r.] [w:] Dzieła, t. 14/2, Warszawa: Instytut Badań Literackich.

$\rightarrow$ Weber, M. (2011), Etyka protestancka i duch kapitalizmu, tłum. D. Lachowska, Warszawa: Wydawnictwa Uniwersytetu Warszawskiego.

$\rightarrow$ Sedláček, T. (2011), Ekonomia dobra i zła, tłum. D. Bakalarz, Warszawa: Studio Emka. 


\section{Netografia}

$\rightarrow$ Humanistic Management Center, www.humanisticmanagement.org (dostęp 20.11.2018).

$\rightarrow$ Korczak, J. (1939), Pedagogika żartobliwa, Warszawa: Wydawnictwo J. Mortkowicza, www.dbc.wroc.pl/Content/13804/RP1342_Pedagogika_zartobliwa. pdf (dostęp: 20.11.2018).

$\rightarrow$ Korczak, J. (2012), Jak kochać dziecko. Dziecko w rodzinie, Warszawa: Biuro Rzecznika Praw Dziecka. Por. również rozważania na ten temat na kolejnych stronach, s. 79-83, brpd.gov.pl/sites/default/files/jak_kochac_dziecko_dziecko_w_rodzinie.pdf (dostęp: 20.11.2018).

$\rightarrow$ Lasota, W. (2017), Janusz Korczak w starej i nowej Europie [w:] Janusz Korczak w starej i nowej Europie, Warszawa: Fundacja Korczakowska, issuu.com/korczakowska/docs/janusz_korczak_w_starej_i_nowej_eur (dostęp: 20.11.2018).

$\rightarrow$ Medvedeva-Nathoo, O. (2012), Oby im życie łatwiejsze było, Poznań: Uniwersytet im. Adama Mickiewicza, www.januszkorczak.ca/wp-content/ uploads/2016/12/Janusz-Korczak_2012.pdf (dostęp: 27.11.2018).

$\rightarrow$ Nienieodpowiedzialni, nienieodpowiedzialni.pl (dostęp: 20.11.2018).

$\rightarrow$ Open Eyes Economy, oees.pl (dostęp: 20.11.2018).

$\rightarrow$ Zalecenie Rady z dnia 22 maja 2018 r. w sprawie kompetencji kluczowych w procesie uczenia się przez całe życie, eur-lex.europa.eu/legal-content/PL/TXT/ PDF/?uri=CELEX:32018H0604(01)\&from=en (dostęp: 27.11.2018). 


\section{Bankructwo malego Dżeka Janusza Korczaka jako studium przedsiębiorczości}

Zygmunt Kawecki

Janusz Korczak napisał Bankructwo małego Dżeka, aby pokazać zarówno dzieciom, jak i dorosłym proste zasady ekonomiczne w gospodarce rynkowej. W swojej powieści odniósł się do przykładu dziecka żyjącego w społeczeństwie amerykańskim, które w fazie swojego rozwoju w szkole podstawowej nagle postanawia poprowadzić klasową wypożyczalnię książek, a następnie rozszerza działalność na zainteresowania koleżanek i kolegów z klasy. Ta krótka powieść stanowi kompendium przedsiębiorczości. Zdaniem autora warto przywrócić ją do kanonu lektur języka polskiego, choć może się zdarzyć, że ze względu na archaiczny język i luki wykształcenia ekonomicznego współczesnej młodzieży i ich rodziców nie będzie się cieszyła powodzeniem. Stąd przypomnienie lektury obowiązującej wiele lat temu, aby rozpocząć właściwe kształtowanie przedsiębiorczych postaw już od najmłodszych lat. W niniejszym tekście przedstawiono interpretację starego tekstu literackiego w świetle nowej podstawy programowej z przedsiębiorczości.

\section{Słowa kluczowe:}

\section{edukacja ekonomiczna}

edukacja w zakresie przedsiębiorczości

Janusz Korczak

kompetencje kluczowe

kompetencje przedsiębiorcze

podstawa programowa

postawy przedsiębiorcze dzieci i młodzieży 


\section{Bankruptcy of Little Jack \\ by Janusz Korczak as a study \\ of entrepreneurship}

Zygmunt Kawecki

Janusz Korczak wrote a story of Bankruptcy of Little Jack to show both children and adults simple rules in market economy. In his story, Korczak showed a young American boy, who was a pupil of elementary school. Suddenly, this child decided to run a business of his own as a librarian in his class. Beingin his third class, he expanded his school business considering interests of his colleagues. This short story written by Korczak presents the core of entrepreneurial competences. In author's opinion, this story, written nearly 100 years ago,is worth bringing back to the set of books obligatory in the Polish language education. However, it might be not interesting for the youth, because of an archaic language and a lack of economy knowledge among young children and their parents. Despite of the outdated form, the story written by Korczak is an example how to develop and from entrepreneurial attitude among children. This chapter presents an interpretation of the old literary text in the light of the new entrepreneurship curriculum.

\section{Keywords:}

economic education

entrepreneurship education

entrepreneurial attitudes of children and youth

Janusz Korczak

key competences

entrepreneurial competences

core curriculum 


\section{Wstęp}

Nierzadko można się spotkać z opinią, że nauczanie przedsiębiorczości w szkołach ogólnokształcących jest nieporozumieniem, że tego nie można nauczyć, tylko trzeba po prostu ją w sobie mieć, więc albo ma się zdolność i ochotę do podejmowania oraz prowadzenia działalności gospodarczej, albo się jej nie ma i mieć nie będzie. Często dodaje się do tego jeszcze, że pojawienie się przedsiębiorczości jako przedmiotu jest przejawem kapitalistycznego neofityzmu. Zapomina się przy tym, że działalność gospodarcza jest rodzajem aktywności społecznej i człowiek wyedukowany, choć na przeciętnym poziomie, powinien ją rozumieć, co wcale nie znaczy, że powinien ją prowadzić. Generalnie, jak się wydaje, w systemie edukacji często nie docenia się wychowawczych funkcji ani możliwości pojawiających się przy nauczaniu przedsiębiorczości. Uwadze krytyków umyka zwłaszcza patriotyczny aspekt nauczania tego przedmiotu.

Doceniano go w pierwszych latach niepodległości naszego kraju odzyskanej po zakończeniu pierwszej wojny światowej, gdy trzeba było odbudować gospodarkę i gdy potrzebni byli ludzie, którzy potrafiliby, a zarazem chcieliby, podjąć ten trud i umieli świadomie włączyć się w tę pracę. Był to czas tłumaczenia ludziom, na czym polega działanie demokratycznego państwa, czym jest wolność gospodarcza i na czym polega odpowiedzialne społecznie podejmowanie i prowadzenie działalności gospodarczej.

Zdano sobie sprawę, że tę „pracę u podstaw" trzeba zaczynać od najmłodszych, bo oni są przyszłością polskiego samostanowienia i polskiej gospodarki. Starano się promować owo dzieło rozmaitymi sposobami. Jednym z nich było pokazywanie dzieciom, czym są państwo i gospodarka, zachęcając je do lektury książek pokazujących, co stanowi ich istotę oraz mechanizm funkcjonowania i rozwoju. Takie książki zaczęły zatem powstawać. Szczególnie udane okazały się te, które wyszły spod pióra Janusza Korczaka, nie tylko wybitnego nauczyciela i wychowawcy, lecz także pisarza. Pisząc Króla Maciusia Pierwszego, pokazywał w baśniowej formie, jak funkcjonuje państwo, i przekonywał, że powinno to być państwo demokratyczne. Natomiast zawiłości gospodarki i gospodarowania przedstawił w książce Bankructwo małego Dżeka.

\section{Edukacja ekonomiczna i promowanie postaw przedsiębiorczych w Bankructwie malego Dżeka}

Książka została napisana głównie dla dzieci w wieku szkoły podstawowej, ale jest to lektura wzbogacająca wiedzę zarówno dzieci, 
jak i dorosłych. Propaguje wartości, które można rozpatrywać w różnych aspektach, zwłaszcza że traktuje o aktywności dzieci w wieku szkolnym. Pokazuje, jak należy kształtować ich przedsiębiorcze postawy, i dowodzi, że należy ich uczyć już na wczesnym etapie edukacji młodych ludzi.

Powieść ta została napisana przez Janusza Korczaka blisko 100 lat temu, jest więc nieco archaiczna językowo, ale zawiera ponadczasowy przekaz. Jej bohaterami oprócz małego Dżeka są jego koleżanki i koledzy z klasy. Książka jest ciekawym spojrzeniem autora na ówczesny świat, a przede wszystkim na gospodarkę, która w swej istocie jest ponadczasowa co do meritum, choć zmienne są formy jej przejawiania. Przedstawiając zachowania dzieci, Korczak wprowadza czytelnika w świat gospodarki. Przywołuje elementarne zasady etyki i ludzkiej psychiki, podkreśla potrzebę uczenia się. Autor przenosi czytelników w świat finansów w taki sposób, że zdaje się wywoływać u nich potrzebę bycia przedsiębiorczym, a jednocześnie uświadamia ryzyko związane z podejmowaniem i prowadzeniem działalności gospodarczej i pokazuje, jak sobie z nim radzić. Wczytując się dokładnie w treść tej książki, można w niej odnaleźć myśli i cele dydaktyczne oraz wychowawcze, które także przyświecały autorom obecnej podstawy nauczania przedsiębiorczości (Rachwał i in. 2018; Borowiec-Gabryś, Kilar, Rachwał 2018). Nawiązują one także do wytycznych wynikających z poprzednich podstaw programowych, celów i treści kształcenia określonych w programach nauczania (Kurek, Rachwał, Szubert 2012; Rachwał, Kurek, Boguś 2016) oraz podręczników do przedsiębiorczości (Makieła, Rachwał 2002a, 2002b, 2015).

Literacka narracja dotyczy świata dziecięcego i jego kontekstów z początków ubiegłego wieku, ale kreśli uniwersalne mechanizmy rządzące gospodarką i gospodarowaniem. Symptomatyczne jest przy tym właśnie to, że zakres wiedzy, jaki płynie z lektury tej powieści, jest kompatybilny $z$ wiedzą, umiejętnościami i postawami wskazanymi w aktualnej podstawie programowej podstaw przedsiębiorczości nauczanych w polskich szkołach. Co więcej, Korczak pokazuje, co czują bohaterowie tej powieści, nawiązując różnego rodzaju relacje, dokonując wyborów, a zwłaszcza podejmując próby rozwiązania wielu problemów, jakie rodzi rozpoczynanie i prowadzenie działalności gospodarczej w świecie, który daleki jest od ideału. Wskazuje, jak ważne są w takich sytuacjach motywacja i cechująca dzieci chęć skutecznego działania. Dowodzi, że przedsiębiorczość jest immanentną cechą psychiczną człowieka, 
a więc także dziecka, a rzecz jedynie w tym, by ją umieć wydobyć i pozytywnie uformować.

\section{Walory wychowawcze powieści}

Korczak pokazuje, że w celu podjęcia i prowadzenia działalności gospodarczej z zamiarem odniesienia sukcesu i sprostania wyzwaniom, jakie niesie ryzyko związane z jej uprawianiem, trzeba mieć pewne przymioty i pewną wiedzę o mechanizmach i prawidłowościach rządzących tą działalnością oraz związanych z nią "dobrych praktykach". Korczak opisuje cechy charakteru, które powinien posiadać człowiek prowadzący działalność gospodarczą, oraz zakres wiedzy, który może wspierać małego przedsiębiorcę w chwilach sukcesu i w momentach porażki. To zaś stanowi nie tylko o walorach edukacyjnych tej książki, lecz także o jej walorach wychowawczych, a jej zasadniczym uniwersalnym przesłaniem jest teza, że ludzi trzeba od najmłodszych lat zaznajamiać z mechanizmami rządzącymi gospodarką i gospodarowaniem, wykorzystując przy tym naturalną ludzką skłonność do bycia przedsiębiorczym, traktowaną jako narzędzie wychowawcze. Choć należy przyznać, że teza ta nigdzie na kartach tej książki nie została wprost przedstawiona.

\section{Rola rodziców w kształtowaniu postaw przedsiębiorczych dzieci}

Korczak pokazuje, że dzieci sposobione do przedsiębiorczości i wychowywane poprzez nią wymagają wsparcia ze strony dorosłych, którzy powinni pomagać im w realizacji ich planów. Skuteczna pomoc starszych powinna mieć charakter wzajemnego dialogu dorosłych i dzieci. Autor wskazuje na znaczenie dialogu od początku powieści, kiedy poznajemy małego Dżeka, jego dom, rodziców i młodszą siostrę. Korczak podkreśla, że Dżek jest kochany przez swoich rodziców. Rodzice rozmawiają z nim i tłumaczą zasady, które obowiązują w życiu. Z tych rozmów Dżek wynosi takie wartości jak uczciwość, pracowitość i punktualność, które powinny także cechować człowieka o postawie przedsiębiorczej. Nie są to tylko czcze słowa, bo przykład pracowitych rodziców kształtuje charakter małego Dżeka, przekonując go, że nie tylko mówią, jak należy postępować, lecz także sami tak właśnie postępują. W domu Dżeka się nie przelewa. Rodzice chłopca rozważnie i ostrożnie podejmują wszelkie finansowe decyzje. Z takimi samymi problemami będzie musiał się uporać już wkrótce w szkole mały Dżek. Mierząc się z nimi, stara się być 
szlachetny. Postępuje podobnie jak jego ojciec, który myśląc o swoich dzieciach, potrafił sobie odmawiać drobnych przyjemności.

Ojciec Dżeka podkreśla, że wszystko, co osiągnął, zawdzięcza pracy własnych rąk. I tę prostą zasadę mały Dżek wprowadza powoli w swoje życie. Na początku dostrzega, że nie ma w szkole przyjaciół, a przecież powinien ich mieć. Szybko uczy się, że działając na rzecz klasy i szkoły, można pozyskać przyjaźń oraz wsparcie koleżanek i kolegów. Dżek jest dobrze ułożonym chłopcem. Jest to cecha charakteru, którą wyniósł z rodzinnego domu. Trafia do szkoły, która uczy szacunku dla ludzi i przedmiotów. Jest to także postawa, którą Dżek wyniósł z domu. Ojciec wpoił mu poszanowanie książek oraz zamiłowanie do porządku wokół siebie. Czytanie książek oraz utrzymanie ładu to umiejętności, które potem przydadzą się Dżekowi w założonym przez niego „biznesie", bo prowadzenie działalności gospodarczej tego wymaga.

\section{Cechy osobowości Dżeka jako wyraz postaw etycznej przedsiębiorczości}

Dżek stara się tak rozmawiać z dziećmi i dorosłymi, aby nikogo nie urazić. Wie, że jeśli w rozmowach z dorosłymi dobiera się słowa podkreślające szacunek dla nich, to w konsekwencji można liczyć u nich "na lepsze rezultaty". Potrafi też być asertywny, a więc posiada kolejną cechę ważną dla osoby przedsiębiorczej (Rachwał 2004, 2005, 2006). W sytuacji, w której nie chce pożyczyć swojej książki koledze, potrafi przedstawić wychowawczyni konkretny argument. Broni go nawet za cenę upokorzenia i popadnięcia w niełaskę u nauczycielki. Tymczasem wychowawczyni po prostu nie zrozumiała Dżeka, a co gorsza, chłopiec lepiej materialnie sytuowany niż Dżek wyszedł w tym starciu na anioła, choć nim nie był. Korczak pokazał tym samym oblicze sporej, niestety, części prowadzących działalność gospodarczą, czasem tak roszczeniowe, że aż trudno zrozumieć, dlaczego takie jest.

Jednak Dżek potrafi być koleżeński, kiedy pożycza innemu koledze ostatnią stalówkę podczas dyktanda i ryzykuje, że sam może zostać bez pióra, jeśli to jemu przytrafi się złamanie stalówki. Z tej prostej sytuacji wyłania się postawa chłopca, który potrafi podjąć ryzyko, a jednocześnie być przyjaznym ludziom, osoba o postawie przedsiębiorczej powinna zaś właśnie taka być. Umiejętne podejmowanie ryzyka jest bowiem niezbędne we wszelkiego rodzaju zachowaniach towarzyszących działalności gospodarczej. Znajduje to swoje odzwierciedlenie 
we współczesnej podstawie programowej z przedsiębiorczości (Rachwał $\mathrm{i}$ in. 2018) i było podkreślane w próbach definiowania przedsiębiorczości jako cechy osobowości (Rachwał 2005).

\section{Rola szkoły w kształtowaniu postaw przedsiębiorczych}

Szkoła, do której uczęszcza mały Dżek, jest typowa. Niczym się nie wyróżnia. Mimo upływu lat przypomina współczesną. Dzieci zachowują się podobnie jak współczesne dzieci. Niektóre są grzeczne, a inne nie, niektóre chcą się dobrze uczyć, a inne wręcz przeciwnie, ale wszystkie chcą się spełniać, realizując różnego rodzaju aktywności. Są takie dzieci, które psocą, i te podlegają karom powszechnie stosowanym wtedy w szkołach. Jednak kiedy przyjrzymy się dokładniej wychowawczyni, uczniom i ich rodzicom, wyłania się obraz szkoły, w której uczeń jest traktowany podmiotowo, natomiast nauczyciel jest osobą odpowiedzialną za wychowanie wszystkich dzieci i jest kimś na wzór urzędnika państwowego, któremu należy się szacunek.

Najważniejszym momentem w szkolnym życiu małego Dżeka wydaje się ten, kiedy na prośbę wychowawczyni chłopak zgodził się poprowadzić klasową biblioteczkę. Wykorzystywał w tej pracy cechy, które nabył w swoim dotychczasowym życiu. Było to zamiłowanie do czytania, ładu i porządku, ale były to również: uczciwość, asertywne przedstawianie argumentów oraz szacunek do ludzi. Te cechy stanowiły fundament i przygotowanie do prowadzenia własnej działalności gospodarczej. Pozwalały rozpoznawać to, co dobre, i to, co złe, pozwalały postępować w sposób, który dziś nazywamy społecznie odpowiedzialnym. Odniesienia do społecznej odpowiedzialności przedsiębiorców oraz uczciwości w biznesie i szacunku dla innych osób mają swoje znaczące miejsce we współczesnej podstawie programowej (Rachwał i in. 2018).

\section{Rola dziadków i innych osób dorosłych} w rozwijaniu postaw przedsiębiorczych dzieci

Kolejny milowy krok w życiu małego Dżeka nastąpił, kiedy dostał od dziadka jednego dolara. W podziękowaniu napisał, że przeznaczy ten pieniądz na zakup książek, ponieważ w szkole pełni funkcję bibliotekarza. Postanawia je kupić w sklepie pana Tafta. Dżek zna pana Tafta z wcześniejszych zakupów i sądzi, że ten darzy go dużym zaufaniem. Janusz Korczak nazywa pieniądze otrzymane od dziadka kapitałem zakładowym działalności gospodarczej, jaką jest prowadzona przez 
Dżeka klasowa biblioteka. W symboliczny, piękny sposób autor wskazał więc na rolę dziadków w rozwijaniu postaw przedsiębiorczych wnuków.

Od tego momentu zaczynają się bliższe spotkania Dżeka z panem Taftem, ale zanim do tego doszło, Dżek musiał przekonać starego sklepikarza o swoich uczciwych zamiarach oraz o tym, że nie zrobił niczego złego, zdobywając pieniądze, z którymi przyszedł. Choć wykazał się asertywnością, dopiero interwencja matki rozproszyła podejrzliwość starego subiekta. Wkrótce pan Taft stał się głównym doradcą biznesowym małego Dżeka. Pomagał mu sprawdzać rachunki, a więc badał finanse prowadzonej przez niego działalności gospodarczej pod kątem jej pasywów i aktywów. Nazywał je "książką wpływów" i „książką wydatków". Na ich podstawie dokonał bilansu przedsięwzięcia Dżeka przed rozszerzeniem działalności, ponieważ Dżek postanowił zdobyć od dzieci nowe środki finansowe i założyć kooperatywę, czyli coś w rodzaju spółdzielni czy spółki z ograniczoną odpowiedzialnością mającej wielu udziałowców.

Było to kolejne przedsiębiorcze działanie, którego bez pomocy osoby dorosłej z dużym doświadczeniem w prowadzeniu działalności gospodarczej małe dziecko nie byłoby sobie w stanie wyobrazić ani z którym nie umiałoby sobie poradzić. Nawet pomoc i przychylność wychowawczyni na niewiele by się zdała, ponieważ pozyskanie nowych środków finansowych od dzieci wiązało się z dużą odpowiedzialnością i mogła tego dokonać jedynie osoba, która już się sprawdziła w prowadzeniu działalności gospodarczej i cieszyła zaufaniem społecznym. W przypadku Dżeka chodziło o zaufanie klasy, wychowawczyni i dyrekcji szkoły.

Po rozszerzeniu działalności Dżek jako osoba w sposób szczególny narażona na wszelkiego rodzaju podejrzenia oraz negatywne zachowania kolegów spotyka się z ich nieetycznymi zachowaniami. Jest mu z tego powodu szczególnie przykro. W głębi swojej dziecięcej duszy mocno przeżywa takie sytuacje, przenosząc je do domu. Dla rodziców był to sygnał, że z ich synem dzieje się coś złego i należy go wspierać. Olbrzymią pomoc okazała mama, która porozmawiała z panem Taftem i poradziła Dżekowi, aby nie podejmował żadnej ważnej decyzji bez niego. Znamy w działalności gospodarczej takie osoby lub firmy, które podejmują się udzielenia wsparcia podmiotom gospodarczym $\mathrm{i}$ indywidualnym osobom, aby zapobiec wypaleniu i frustracjom, zwłaszcza w obliczu nieetycznej konkurencji. W przypadku Dżeka wiązało się to 
także z jego relacjami z kolegami, którzy nie szczędzili mu sarkastycznych i uszczypliwych przymiotników, ponieważ zwyczajnie mu zazdrościli sukcesu.

\section{Kształtowanie postaw przezwyciężania trudnych momentów w biznesie}

Jednak najtrudniejszy moment Dżek miał jeszcze przed sobą. Po rozszerzeniu działalności i zorganizowaniu kooperatywy stał się stałym bywalcem w sklepie pana Tafta. Tam uczył się pod jego pilnym okiem rachunkowości, w czym przydawała się znajomość matematyki. Pan Taft poprawiał również błędy ortograficzne, zwracając uwagę na porządek i poprawność zapisów. Dał też Dżekowi rekomendacje do swojego byłego wychowanka, który podstawy wiedzy o prowadzeniu działalności gospodarczej zdobywał w jego sklepie, a obecnie prowadzi hurtownię, i który za pośrednictwem pana Tafta wspierał działalność gospodarczą małego Dżeka. Tym samym chłopiec mógł rozszerzyć asortyment prowadzonej działalności.

$Z$ jednej strony wzbudzało to podziw u innych, a z drugiej rodziło zachowania negatywne. Na takie nieprzyjazne zachowania musi być przygotowany każdy, kto podejmuje się prowadzenia działalności gospodarczej. Rady pana Tafta objaśniały małemu Dżekowi takie pojęcia jak „,notariusz", ,kasa pożyczkowa”, ,wierzyciel”, , ,bank" i „kredyt”, dzięki czemu został wprowadzony w sztukę zabezpieczania się przed nieuczciwością różnych osób. Korzystając z tej wiedzy, zawarł umowę na zakup rowerów dla swojej kooperatywy. Wkrótce przeżył jednak szok, kiedy rowery zostały skradzione, a kooperatywa zbankrutowała. Doświadczył tym samym tego, na czym polega nieuczciwość i niekorzystny, a niespodziewany przypadek losowy w prowadzeniu działalności gospodarczej. Zrozumiał, że są ludzie i firmy, którzy nie mają żadnych skrupułów w niegodziwych zachowaniach, ale dowiedział się też, że prowadząc działalność gospodarczą, nigdy nie należy tracić nadziei ani wiary w to, że można "odbić się od dna". Dżekowi dopisało bowiem szczęście i rowery się odnalazły, choć on sam z powodu bankructwa podczas wakacji odpracowywał finansowe zaległości w sklepie pana Tafta, ucząc się jednocześnie trudnej, a zarazem odpowiedzialnej społecznie sztuki bycia kupcem, czy - jak byśmy to dziś powiedzieli - handlowcem. 
Warto też zauważyć, za M. Glińskim (2018), że wspólnym mianownikiem wszystkich powieściowych zwrotów akcji jest pojęcie odpowiedzialności, a Korczak poprzez nieprzewidywalną ekonomiczną rzeczywistość pokazuje, iż każde działanie przynosi skutek i wiąże się z odpowiedzialnością. Dlatego można jego zdaniem powieść traktować jako podręcznik działania odpowiedzialnego (Gliński 2018). Należy przy tym zauważyć, że odpowiedzialność za podejmowane decyzje i swoje działania oraz innych ludzi traktowana jest jako jeden z podstawowych elementów przedsiębiorczości (Rachwał 2004), a w nowej podstawie programowej szczególne miejsce zajmują wymagania odnoszące się do kształtowania postaw, zwłaszcza odpowiedzialności (Rachwał i in. 2018).

\section{Podsumowanie - walory wychowawcze} i edukacyjne powieści

Jak wynika z powyższych rozważań, powieść Janusza Korczaka wprowadza treści, które stanowią podstawową wiedzę z zakresu przedsiębiorczości. Kształtuje umiejętności, które są konieczne w praktyce ludzkich zachowań w gospodarce i gospodarowaniu, pokazuje namacalnie, czym są postawy przedsiębiorcze oraz jak się one kształtują i jak powinny być kształtowane. Uzmysławia, że kształtowanie aktywności, odpowiedzialności za siebie i innych oraz umiejętne godzenie własnego dobra z dobrem innych ludzi jest podstawą współpracy, koniecznej tak w życiu, jak i w działalności gospodarczej.

Przedstawione w tej książce relacje Dżeka z koleżankami i kolegami dowodzą jasno, że bez zastosowania zasad pracy zespołowej nie byłoby sukcesu prowadzonej przez niego kooperatywy. Lektura tej, nieco zapomnianej już, powieści jest wielce przydatna z punktu widzenia wprowadzania do szkół elementów wiedzy o gospodarce i gospodarowaniu, zwanej niezbyt szczęśliwie „przedsiębiorczością". Korczak sugerował tą powieścią potrzebę, a zarazem konieczność uczenia dzieci zasad prowadzenia drobnych przedsięwzięć gospodarczych już od wczesnych lat dzieciństwa. Nie pozostawiał złudzeń co do tego, że każda działalność gospodarcza obarczona jest ryzykiem i wymaga przewidywania wielu zagrożeń, ale jednocześnie pokazywał, jak sobie z nimi radzić. Dowodził, że bycie społecznie aktywnym i odpowiedzialnym kształtuje właściwe postawy życiowe, a podejmowanie działalności gospodarczej 
przez dzieci jest doskonałym narzędziem wychowawczym i edukacyjnym zarazem.

Opowiadając historię małego Dżeka i jego bankructwa, Korczak zaprezentował w tej książce, niejako pośrednio, swoje zasady wychowywania dzieci. Pokazał, że najważniejsze w kształceniu i wychowywaniu jest dobro dziecka, że dziecku należy ufać i dziecko należy bronić. Warto o tych zasadach pamiętać i należy się ich trzymać, ucząc młodych ludzi wszystkiego, czego ich nauczyć trzeba, a więc i przedsiębiorczości. Jej nauczanie będzie jednak naprawdę skuteczne i atrakcyjne, a jednocześnie wychowawczo owocne, jeśli uda się teoretyczną wiedzę o gospodarce i gospodarowaniu połączyć z praktycznym działaniem. 


\section{Bibliografia}

$\rightarrow$ Borowiec-Gabryś, M., Kilar, W., Rachwał, T. (2018), Przedsiębiorczość jako kompetencja przyszłości [w:] S. Kwiatkowski (red.), Kompetencje przyszłości, Seria Naukowa, t. 3, Warszawa: Fundacja Rozwoju Systemu Edukacji, s. 68-89.

$\rightarrow$ Korczak, J. (1924), Bankructwo małego Dżeka (I wydanie), Warszawa-Kraków: Towarzystwo Wydawnicze w Warszawie.

$\rightarrow$ Korczak, J. (1959), Bankructwo małego Dżeka (wydanie powojenne), Warszawa: Nasza Księgarnia.

$\rightarrow$ Kurek, S., Rachwał, T., Szubert, M. (2012), Business Competencies in Polish School Curricula: Opinions of Teachers and Social Partners [w:] M. Pilz, S. Berger, R. Canning (red.), Fit for Business. Pre-Vocational Education in European Schools, VS Verlag für Sozialwissenschaften, Wiesbaden: Springer, s. 61-88.

$\rightarrow$ Makieła, Z., Rachwał, T. (2002a), Podstawy przedsiębiorczości. Program nauczania dla liceum ogólnokształcącego, liceum profilowanego i technikum, Warszawa: Wydawnictwo Nowa Era.

$\rightarrow$ Makieła, Z., Rachwał, T. (2002b), Podstawy przedsiębiorczości. Podręcznik dla liceum ogólnokształcq̨cego, liceum profilowanego i technikum, Warszawa: Wydawnictwo Nowa Era.

$\rightarrow$ Makieła, Z., Rachwał, T. (2015), Krok w przedsiębiorczość. Podręcznik do podstaw przedsiębiorczości dla szkół ponadgimnazjalnych, Warszawa: Nowa Era.

$\rightarrow$ Rachwał, T. (2004), Podstawy przedsiębiorczości - słownik dla liceum ogólnokształcącego, liceum profilowanego i technikum, Warszawa: Wydawnictwo Nowa Era.

$\rightarrow$ Rachwał, T. (2005), Kształtowanie postaw uczniów na lekcjach podstaw przedsiębiorczości, „Przedsiębiorczość - Edukacja”, nr 1, s. 137-144.

$\rightarrow$ Rachwał, T. (2006), Kształtowanie postaw przedsiębiorczych w edukacji szkolnej [w:] B. Muchacka (red.), Szkoła w nauce i praktyce edukacyjnej, t. 2, Kraków: Oficyna Wydawnicza "Impuls", Akademia Pedagogiczna w Krakowie, s. 427-434. 
$\rightarrow$ Rachwał, T. (2017), Entrepreneurship in School in the Conditions of the Education System Reform in Poland - a Voice in the Discussion on the Directions of Change, „Przedsiębiorczość - Edukacja” („Entrepreneurship-Education”), nr 13, s. 330-339.

$\rightarrow$ Rachwał, T., Kilar, W., Kawecki, Z., Wróbel, P. (2018), Edukacja w zakresie przedsiębiorczości w wychowaniu przedszkolnym, szkole podstawowej i szkołach średnich w świetle nowej podstawy programowej, „Przedsiębiorczość - Edukacja", nr 14, s. 389-424.

$\rightarrow$ Rachwał, T., Kurek, S., Boguś, M. (2016), Entrepreneurship Education at Secondary Level in Transition Economies: A Case of Poland " Entrepreneurial Business and Economics Review", nr 4 (1), s. 61-81. 


\section{Netografia}

$\rightarrow$ Gliński, M. (2018), Janusz Korczak - Bankructwo małego Dżeka, culture.pl, culture.pl/pl/dzielo/janusz-korczak-bankructwo-malego-dzeka [dostęp 30.12.2018]. 


\section{Przedsiębiorczość w edukacji przedszkolnej i szkole \\ podstawowej $w$ warunkach zmian \\ podstawy programowej}

Wioletta Kilar, Tomasz Rachwał

Powszechnie przyjmuje się, że celowe jest włączenie treści z zakresu przedsiębiorczości w podstawy programowe i programy nauczania niemal wszystkich przedmiotów szkolnych od najmłodszych etapów edukacji. Podstawa programowa w Polsce, wprowadzana sukcesywnie w szkołach podstawowych od 2017 r., stara się nawiązywać do tej idei. Celem niniejszego opracowania jest więc przedstawienie wyników analiz nowej podstawy programowej wychowania przedszkolnego i kształcenia ogólnego w szkole podstawowej pod kątem treści związanych z przedsiębiorczością oraz próba odpowiedzi na pytanie, w jakiej mierze zapisy nowej podstawy programowej sprzyjają kształtowaniu postaw przedsiębiorczych dzieci i młodzieży.

\section{Słowa kluczowe:}

edukacja dzieci i młodzieży

edukacja w zakresie przedsiębiorczości

podstawa programowa

postawa przedsiębiorcza

rozwój dziecka 


\section{Entrepreneurship in preschool and primary education and the core curriculum changes}

Wioletta Kilar, Tomasz Rachwał

It is generally accepted that it is purposeful to include entrepreneurial goals and content in the curricula of all school subjects from the youngest stages of education. The new core curriculum in Poland, introduced successively at primary schools since 2017 , tries to refer to this idea. The aim of the chapter is therefore to present the results of analyses of the new core curriculum of preschool education and general education in primary school in terms of entrepreneurshiprelated content. It answers the question to what extent the provisions of the new core curriculum favour the shaping of entrepreneurial attitudes of children and youth.

\section{- Keywords: \\ education of children and youth \\ entrepreneurship education \\ core curriculum \\ entrepreneurial attitude \\ child development}




\section{Wprowadzenie}

Przyjmuje się powszechnie, że przedsiębiorczość nie jest wrodzoną cechą osobowości człowieka, ale postawą, którą można kształtować i rozwijać w toku wychowania i edukacji szkolnej od najmłodszych lat. Poznawanie i stopniowe rozumienie otaczającego świata następuje u dziecka od pierwszych dni życia, gdyż każdego dnia nabywa ono nowych umiejętności i pogłębia swoją wiedzę w zakresie funkcjonowania otaczającego je świata, co odbywa się zarówno formalnie, w przedszkolu czy później w szkole, jak i nieformalnie, w codziennym życiu. W tej sytuacji również kształtowanie postaw przedsiębiorczych następuje stopniowo i odbywa się przez obserwację dorosłych, szczególnie rodziców i pozostałych członków rodziny, oraz przez uczestnictwo w zajęciach przedszkolnych i szkolnych. Szczególną rolę w początkowych latach życia odgrywa kształtowanie postaw twórczych, które należy zaliczyć do podstawowych elementów postawy przedsiębiorczej. Kluczowe jest tutaj wspieranie dziecka w rozpoznawaniu i rozwijaniu własnych uzdolnień oraz zaradności i inicjatywności, a także sztuki uczenia się, która jest fundamentem dalszego zdobywania wiedzy i nowych umiejętności. Jest to bardzo ważny aspekt przedsiębiorczości. Lidia Wollman $(2015,2017)$ podkreśla, że przedsiębiorczy człowiek chce, lubi i potrafi się uczyć, nieustannie rozwija swój potencjał i wciąż dąży do nowych celów, a także wykorzystuje wszelkie zasoby wokół siebie (materialne i ludzkie), by wspomóc swój proces uczenia się i różne strategie poznawcze. Przedsiębiorczość w zakresie uczenia się powinna więc być kształtowana i rozwijana od najmłodszych lat, na co wskazuje wielu autorów (por. między innymi: Oeszlaeger-Kosturek 2017, Rachwał 2005, 2006, Raszka 2017, Wach 2013, 2014, Wollman 2017, Zioło 2012). Umożliwia to przygotowanie młodego człowieka do wyzwań, jakie czekają go w życiu dorosłym, kiedy będzie musiał wziąć odpowiedzialność za swoje życie zawodowe i rodzinne. Tych wyzwań we współczesnym świecie jest wiele, gdyż w dzisiejszej, dynamicznie zmieniającej się rzeczywistości nie można niczego być pewnym, szczególnie w zakresie długoterminowych perspektyw rozwoju kariery zawodowej. Jako nauczyciele musimy mieć świadomość, że nasi uczniowie będą funkcjonować w świecie, którego kształtu nie znamy, pracować w zawodach, które jeszcze nie istnieją, i wykonywać obowiązki zawodowe, o których obecnie nie mamy pojęcia, a które mogą różnić się znacznie od tego, jak wyglądają one dzisiaj. Stąd konieczne jest przygotowanie 
w toku edukacji przedsiębiorczego i kompetentnego człowieka, który będzie w stanie sprostać tym wyzwaniom i adaptować się do zmian otoczenia, osiągając przy tym własne cele życiowe i realizując zamierzenia. Podstawową rolę w tym zakresie odgrywają - oprócz rodziny czy rodziców - przedszkole i szkoła. Dlatego ważne jest ustalenie, w jakim zakresie dokumenty programowe wyznaczają podstawy (cele i treści) kształcenia i umożliwiają rozwijanie postaw przedsiębiorczych czy wręcz wskazują na taką konieczność. Podstawowym celem niniejszego opracowania jest przedstawienie zmian, jakie zaszły $w$ tym zakresie w warunkach reformy programowej systemu oświaty, wdrażanej od 2017 r. w Polsce.

\section{Wprowadzenie do kształtowania postaw przedsiębiorczych $w$ świetle podstawy}

\section{programowej wychowania przedszkolnego}

Edukacja ekonomiczna dzieci w krajach zachodniej i północnej Europy jest prowadzona z reguły bardzo wcześnie, zwykle już na etapie przedszkola. Choć kształcenie w zakresie przedsiębiorczości w Polsce - $w$ formie oddzielnego przedmiotu szkolnego - rozpoczyna się dopiero od szkoły średniej, co było przedmiotem analizy wielu autorów (por. między innymi Rachwał, Kurek, Boguś 2016), to również w Polsce treści z zakresu przedsiębiorczości są wplecione w podstawę programową wychowania i nauczania najmłodszych dzieci. Nie jest to coś zupełnie nowego związanego z reformą systemu szkolnictwa od 2017 r. Jak wynika z badań M. Tracz (2015), która przeprowadziła analizę kształcenia w zakresie przedsiębiorczości w Polsce na tle krajów Unii Europejskiej, kształcenie w zakresie przedsiębiorczości jest jednym z priorytetów polskiej polityki edukacyjnej. Autorka wcześniej wskazywała również dużą rolę podstaw przedsiębiorczości w kształceniu ogólnym (Tracz 2006).

Porównując poprzednią (z 2012 r.) i nową (z 2017 r.) podstawę programową (Rozporządzenie MEN... 2012, 2017) w zakresie treści związanych z przedsiębiorczością, nasuwa się kilka głównych wniosków związanych ze zmianami treści podstawy w przedszkolu i szkole podstawowej.

W podstawie programowej wychowania przedszkolnego ogólnie rozszerzono problematykę przedsiębiorczości na tym najniższym szczeblu kształcenia. Wymagania szczegółowe w tym zakresie wpisują 
się w społeczny obszar rozwoju dziecka. W poprzedniej podstawie programowej sformułowane było tylko jedno ogólne wymaganie szczegółowe, w nowej zaś występują cztery wymagania w zakresie umiejętności społecznych, dotyczących przede wszystkim komunikacji, gospodarstwa domowego oraz życia zawodowego najbliższych (Tab. 1). Tym samym kształcenie w obszarze przedsiębiorczości rozpoczyna się od najmłodszych lat szkolnych przez poznawanie tych zagadnień w najbliższym otoczeniu dziecka.

Odnosi się to w pierwszej kolejności do kształtowania poczucia własnej wartości, na której buduje się umiejętności komunikacji i relacji z innymi ludźmi, niezbędne w życiu prywatnym i w aktywności zawodowej, szczególnie biznesowej, każdego człowieka. Na tym etapie pojawia się także element edukacji finansowej (rozumienie roli pieniądza w życiu rodziny, rozpoznawanie monet i banknotów) oraz związanej z pracą zawodową, co stanowi podbudowę późniejszych treści kształcenia dotyczącego funkcjonowania rynku pracy (na przykładzie wybranych zawodów). Są to ważne treści kształcenia na tym etapie, na co zwracał uwagę T. Kopczyński (2017), wskazując je jako jeden z brakujących elementów kształtowania przedsiębiorczości w przestrzeni edukacyjnej. Choć problematyka ta była realizowana na zajęciach w przedszkolu, to na uwagę zasługuje fakt, że została obecnie wyraźnie zapisana w podstawie programowej i staje się obowiązkowa w kształceniu już na tym etapie, gdyż we wcześniejszej podstawie programowej treści z tego zakresu były zapisane $w$ ramach edukacji wczesnoszkolnej.

$\mathrm{Na}$ rolę edukacji finansowej dzieci, mając świadomość znaczenia tej sfery życia w pomyślnym rozwoju i przyszłości kolejnych pokoleń, zwracało uwagę wielu autorów, między innymi R. Raszka (2017). Wskazuje ona, powołując się także na innych autorów, że edukacja finansowa staje się niezbędną, nawet pilną potrzebą w obecnych czasach, a wychowanie dzieci w tym zakresie jest koniecznością. Wynika to z faktu, że rozumienie wartości pieniądza i radzenie sobie z obliczeniami pieniężnymi należą do podstawowych umiejętności życiowych (Raszka 2017). 
Tabela 1. Zakładane efekty kształcenia związane z przedsiębiorczością zapisane $w$ treściach nauczania - wymaganiach szczegółowych w podstawach programowych wychowania przedszkolnego z lat 2012 i 2017

\begin{tabular}{|c|c|}
\hline NOWA PODSTAWA PROGRAMOWA (2017) & POPRZEDNIA PODSTAWA PROGRAMOWA (2012) \\
\hline $\begin{array}{l}\text { III. Społeczny obszar rozwoju dziecka. Dziecko } \\
\text { przygotowane do podjęcia nauki w szkole: }\end{array}$ & $\begin{array}{l}\text { I. Kształtowanie umiejętności społecznych } \\
\text { dzieci: }\end{array}$ \\
\hline $\begin{array}{l}\text { 1) przejawia poczucie własnej wartości jako } \\
\text { osoby, wyraża szacunek wobec innych osób } \\
\text { i przestrzegając tych wartości, nawiązuje rela- } \\
\text { cje rówieśnicze. }\end{array}$ & $\begin{array}{l}\text { 3) w miarę samodzielnie radzi sobie w sytu- } \\
\text { acjach życiowych i próbuje przewidywać skutki } \\
\text { swoich zachowań. }\end{array}$ \\
\hline $\begin{array}{l}\text { 9) komunikuje się z dziećmi i osobami dorosły- } \\
\text { mi, wykorzystując komunikaty werbalne i poza- } \\
\text { werbalne; wyraża swoje oczekiwania społeczne } \\
\text { wobec innego dziecka, grupy. }\end{array}$ & \\
\hline $\begin{array}{l}\text { 17) rozpoznaje modele monet i banknotów } \\
\text { o niskich nominałach, porządkuje je, rozumie, } \\
\text { do czego służą pieniądze w gospodarstwie } \\
\text { domowym. }\end{array}$ & \\
\hline $\begin{array}{l}\text { 20) wskazuje zawody wykonywane przez } \\
\text { rodziców i osoby z najbliższego otoczenia, } \\
\text { wyjaśnia, czym zajmuje się osoba wykonująca } \\
\text { dany zawód. }\end{array}$ & \\
\hline
\end{tabular}

Źródło: Opracowanie własne na podstawie Rozporządzenie MEN... $(2012,2017)$.

\section{Kształtowanie postaw przedsiębiorczych w edukacji wczesnoszkolnej w świetle podstawy programowej dla klas I-III szkoły podstawowej}

W nowej, ośmioletniej szkole podstawowej w klasach I-III kształcenie w zakresie przedsiębiorczości w ramach edukacji wczesnoszkolnej obejmuje edukację polonistyczną, matematyczną i społeczną (Tab. 2). Również na tym etapie nastąpił wzrost liczby wymagań szczegółowych, zwłaszcza w edukacji społecznej, związanych z przedsiębiorczością. W nowej podstawie uczniowie - oprócz zagadnień związanych z formowaniem się grupy społecznej - powinni również poznać prawa i obowiązki różnych grup (osób), formułować pojęcia takie jak "porozumienie" i "umowa" oraz sytuacje, w których te pojęcia się stosuje, a także rozwijać umiejętności komunikacji w grupie. Również na tym etapie nastąpiło więc rozszerzenie zapisów wymagań szczegółowych. Pozostały także efekty w zakresie komunikacji werbalnej i niewerbalnej jako element kształcenia polonistycznego oraz obliczenia pieniężne 
w edukacji matematycznej. Ważny jest także efekt odnoszący się do samorozwoju i tworzenia indywidualnych strategii uczenia się, co zalicza się do istotnych postaw i umiejętności osoby przedsiębiorczej (Rachwał 2005, Wellman 2015).

W nowej podstawie programowej z 2017 r. pojawiły się efekty szczegółowe obejmujące edukację techniczną, w której przedsiębiorczości uczniowie uczą się w ramach pracy własnej, realizowanej często $w$ formie projektów, poznając przy tej okazji podstawowe zasady organizacji oraz bezpieczeństwa pracy, co stanowi fundament przygotowania do przyszłej pracy zawodowej.

Należy zaznaczyć, że w poprzedniej podstawie programowej, ze względu na nieco inną formę zapisów, występowały także efekty w zakresie przedsiębiorczości, które były oczekiwane od uczniów kończących III klasę szkoły podstawowej, obejmujące edukację plastyczną i społeczną. W nowej podstawie tego typu zapisy nie występują, gdyż część z nich została przeniesiona na etap wychowania przedszkolnego.

Warto przy tym zaznaczyć za R. Raszką (2015), że - jak wynika $z$ analiz treści programów nauczania i podręczników do klas I-III dostosowanych do poprzedniej podstawy programowej - mimo istnienia formalnych zapisów z trudem można było znaleźć zadania służące budowaniu świadomości pieniądza i jego wartości oraz rozsądnego gospodarowania zasobami pieniężnymi. Pozostaje mieć nadzieję, że w warunkach nowej podstawy programowej takie sytuacje, w których marginalizuje się $w$ praktyce edukacyjnej pewne elementy kształcenia ekonomicznego, nie będą występować.

Tabela 2. Zakładane efekty kształcenia związane z przedsiębiorczością zapisane $w$ treściach nauczania - wymaganiach szczegółowych w podstawach programowych z lat 2012 i 2017 dla klas I-III szkoły podstawowej

\begin{tabular}{l|l}
\multicolumn{1}{c|}{ NOWA PODSTAWA PROGRAMOWA (2017) } & \multicolumn{1}{c}{ POPRZEDNIA PODSTAWA PROGRAMOWA (2012) } \\
\hline I. Edukacja polonistyczna. & I. Edukacja polonistyczna. \\
\hline $\begin{array}{l}\text { 1. 1) słucha z uwagą wypowiedzi nauczyciela, } \\
\text { innych osób z otoczenia, w różnych sytu- }\end{array}$ & $\begin{array}{l}\text { 1a) obdarza uwagą dzieci i dorosłych, słucha ich } \\
\text { wypowiedzi i chce zrozumieć, co przekazują; } \\
\text { acjach życiowych, wymagających komunikacji } \\
\text { i wzajemnego zrozumienia; okazuje szacunek } \\
\text { wypowiadającej się osobie. }\end{array}$ \\
\hline
\end{tabular}


2. 7) dobiera stosowną formę komunikacji werbalnej i własnego zachowania, wyrażającą empatię i szacunek do rozmówcy.

6. 3) wykorzystuje nabyte umiejętności do rozwiązywania problemów i eksploracji świata, dbając o własny rozwój i tworząc indywidualne strategie uczenia się.

\begin{tabular}{|c|c|}
\hline II. Edukacja matematyczna. & 7. Edukacja matematyczna. \\
\hline $\begin{array}{l}\text { 6. 3) wykonuje obliczenia pieniężne; zamienia } \\
\text { złote na grosze i odwrotnie, rozróżnia nominały } \\
\text { na monetach i banknotach, wskazuje różnice } \\
\text { w ich sile nabywczej. }\end{array}$ & $\begin{array}{l}\text { 4) w zakresie obliczeń pieniężnych: } \\
\text { a) zna będące w obiegu monety i banknot } \\
\text { o wartości } 10 \text { zł; zna wartość nabywczą monet } \\
\text { i radzi sobie w sytuacji kupna i sprzedaży, } \\
\text { b) zna pojęcie długu i konieczność spłacenia go. }\end{array}$ \\
\hline III. Edukacja społeczna. & 5. Edukacja społeczna. \\
\hline $\begin{array}{l}\text { 1. 1) identyfikuje się z grupą społeczną, do } \\
\text { której należy: rodzina, klasa w szkole, dru- } \\
\text { żyna sportowa, społeczność lokalna, naród; } \\
\text { respektuje normy i reguły postępowania w tych } \\
\text { grupach. }\end{array}$ & $\begin{array}{l}\text { 2) współpracuje z innymi w zabawie, w nauce } \\
\text { szkolnej i w sytuacjach życiowych; przestrzega } \\
\text { reguł obowiązujących w społeczności dziecię- } \\
\text { cej oraz w świecie dorosłych, grzecznie zwraca } \\
\text { się do nich w szkole, w domu i na ulicy. }\end{array}$ \\
\hline
\end{tabular}

1. 2) wyjaśnia, iż wszyscy ludzie posiadają prawa i obowiązki, wymienia własne prawa i obowiązki, przestrzega ich i stosuje je w codziennym życiu.

1. 8) stosuje pojęcia: porozumienie, umowa; uczestniczy w wyborach samorządu uczniowskiego w klasie, w szkole; wymienia przykłady powstałych w efekcie porozumień i umów grup społecznych, np. stowarzyszenia pomocy chorym i niepełnosprawnym dzieciom, organizacje ekologiczne, a także stowarzyszenia dużych grup społecznych, jak miasta i państwa czy Unia Europejska.

1. 10) wykorzystuje pracę zespołową w procesie uczenia się, w tym przyjmując rolę lidera zespołu, i komunikuje się za pomocą nowych technologii.

4) ma rozeznanie, że pieniądze otrzymuje się za prace; dostosowuje swe oczekiwania do realiów ekonomicznych rodziny.

7) potrafi wymienić status administracyjny swojej miejscowości (wieś, miasto); wie, czym zajmuje się np. policjant, strażak, lekarz, weterynarz...

\footnotetext{
VI. Edukacja techniczna.

1. 1) planuje i realizuje własne projekty/prace; realizując te projekty/prace, współdziała w grupie.

1. 2) wyjaśnia znaczenie oraz konieczność zachowania ładu, porządku i dobrej organizacji miejsca pracy ze względów bezpieczeństwa.
} 
1. 3) ocenia projekty/prace, wykorzystując poznane i zaakceptowane wartości: systematyczność działania, pracowitość, konsekwencja, gospodarność, oszczędność, umiar w odniesieniu do korzystania z czasu, materiałów, narzędzi i urządzeń.

4. Edukacja plastyczna. Uczeń kończący klasę III:

2b) realizuje proste projekty $w$ zakresie form użytkowych, w tym służące kształtowaniu własnego wizerunku i otoczenia oraz upowszechnianiu kultury w środowisku szkolnym (stosując określone narzędzia i wytwory przekazów medialnych).

5. Edukacja społeczna. Uczeń kończący klasę III:

2) identyfikuje się ze swoją rodziną i z jej tradycjami; podejmuje obowiązki domowe i rzetelnie je wypełnia; rozumie, co to jest sytuacja ekonomiczna rodziny, i wie, że trzeba do niej dostosować swe oczekiwania.

3) wie, jak należy zachowywać się w stosunku do dorosłych i rówieśników (formy grzecznościowe); rozumie potrzebę utrzymywania dobrych relacji z sąsiadami w miejscu zamieszkania; jest chętny do pomocy, respektuje prawo innych do pracy i wypoczynku.

8) wie, jak ważna jest praca w życiu człowieka; wie, jaki zawód wykonują jego najbliżsi i znajomi; wie, czym zajmuje się np. kolejarz, aptekarz, policjant, weterynarz.

Kształtowanie postaw przedsiębiorczych w klasach IV-VIII szkoły podstawowej $w$ świetle podstawy programowej

W wyższych klasach ośmioletniej szkoły podstawowej (IV-VIII) zagadnienia związane z przedsiębiorczością znajdują się w podstawach programowych poszczególnych przedmiotów szkolnych (Tab. 3).

W podstawie programowej języka polskiego - poza pozostawieniem wymagania obejmującego identyfikację wypowiedzi ( $w$ tym reklamowej) - zapisano także trzy inne efekty odwołujące się do kształcenia w zakresie komunikacji. W najwyższych klasach uczniowie zapoznają się również z tworzeniem wypowiedzi $w$ formie CV czy listu moty- 
wacyjnego, które w szkole średniej są kontynuowane w ramach lekcji przedsiębiorczości.

Kolejnym przedmiotem szkolnym, w którego podstawie znajdujemy treści nawiązujące do przedsiębiorczości, jest wiedza o społeczeństwie. W poprzedniej podstawie programowej w młodszych klasach szkoły podstawowej przedmiot ten był nazwany "historia i społeczeństwo", a dopiero w kolejnym, gimnazjalnym etapie kształcenia występował jako wiedza o społeczeństwie. Zmiana ta spowodowała, że w nowej podstawie programowej pojawia się wiele zapisów efektów szczegółowych odnoszących się do kształtowania przedsiębiorczości: związanych z komunikowaniem się, z konfliktami w grupie, z poznawaniem funkcjonowania gospodarstwa domowego, z planowaniem własnego rozwoju oraz z funkcjonowaniem rynku pracy i samorządu gminnego. W poprzedniej podstawie programowej na etapie szkoły podstawowej pojawił się jedynie jeden zapis dotyczący przedsiębiorczości. Wynikało to $z$ faktu, że na etapie gimnazjum wiedza o społeczeństwie w znacznej części zawierała zagadnienia dotyczące przedsiębiorczości.

W podstawie programowej do szkoły podstawowej w zakresie geografii również znajdujemy kilka zagadnień dotyczących przedsiębiorczości, szczególnie społeczno-gospodarczych aspektów rozwoju obszaru Polski i innych krajów oraz współpracy w zespole. W poprzedniej podstawie, ze względu na to, że dominowało kształcenie w zakresie przyrody, które nie nawiązywało do przedsiębiorczości, nie znajdujemy zapisów dla kształcenia geograficznego, które obejmowałyby przedsiębiorczość. Przywrócenie w szkole podstawowej geografii od V klasy oznacza więc włączenie do kształcenia już na tym etapie elementów geografii społeczno-ekonomicznej, której wiele treści wspiera kształtowanie postaw przedsiębiorczych i osiąganie efektów związanych z wiedzą ekonomiczną o otaczającym świecie. W warunkach poprzedniej podstawy programowej geografia wspierała edukację w zakresie przedsiębiorczości głównie na etapie szkoły ponadgimnazjalnej i częściowo gimnazjum (Borowiec, Rachwał 2011)1.

Obecnie ważnym przedmiotem w szkole podstawowej podnoszącym zagadnienia z przedsiębiorczości jest także wychowanie do życia w rodzinie, w którego podstawie programowej znalazły się zapisy

1. Szerzej o roli geografii w edukacji w zakresie przedsiębiorczości w ośmioletniej szkole podstawowej pisze w niniejszym tomie Monika Borgiasz. 
dotyczące rozszerzania zarówno umiejętności i wiedzy związanych z kształtowaniem postaw, jak i komunikacji, w tym w sytuacjach konfliktowych.

W obecnej podstawie programowej także na etyce pojawiają się obszary nawiązujące do przedsiębiorczości - poznanie własnych wad i zalet oraz praw i obowiązków, które w poprzedniej podstawie programowej nie występowały.

Tabela 3. Zakładane efekty kształcenia związane z przedsiębiorczością zapisane w treściach nauczania - wymaganiach szczegółowych w podstawach programowych z lat 2012 i 2017 dla klas IV-VIII szkoły podstawowej

\begin{tabular}{|c|c|}
\hline NOWA PODSTAWA PROGRAMOWA (2017) & POPRZEDNIA PODSTAWA PROGRAMOWA (2012) \\
\hline \multicolumn{2}{|c|}{ JĘZYK POLSKI } \\
\hline Kształcenie literackie i kulturowe. & $\begin{array}{l}\text { I. Odbiór wypowiedzi i wykorzystanie zawartych } \\
\text { w nich informacji. }\end{array}$ \\
\hline $\begin{array}{l}\text { 2. 1) identyfikuje wypowiedź jako tekst infor- } \\
\text { macyjny, publicystyczny lub reklamowy. }\end{array}$ & $\begin{array}{l}\text { 4) identyfikuje wypowiedź jako tekst informa- } \\
\text { cyjny, literacki, reklamowy. }\end{array}$ \\
\hline \multicolumn{2}{|l|}{$\begin{array}{l}\text { 3. 1) identyfikuje tekst jako komunikat; roz- } \\
\text { różnia typy komunikatu: informacyjny, literacki, } \\
\text { reklamowy, ikoniczny. }\end{array}$} \\
\hline \multicolumn{2}{|l|}{$\begin{array}{l}\text { 3. 3) określa sytuację komunikacyjną i rozumie } \\
\text { jej wpływ na kształt wypowiedzi. }\end{array}$} \\
\hline \multirow[t]{3}{*}{$\begin{array}{l}\text { 3. 4) rozpoznaje znaczenie niewerbalnych środ- } \\
\text { ków komunikacji (np. gest, mimika, postawa } \\
\text { ciała). }\end{array}$} & \\
\hline & 1. Mówienie i pisanie. \\
\hline & $\begin{array}{l}\text { 5) tworzy wypowiedzi pisemne } \\
\text { w następujących formach gatunkowych: } \\
\text { opowiadanie z dialogiem (twórcze } \\
\text { i odtwórcze), pamiętnik i dziennik (pisane } \\
\text { z perspektywy bohatera literackiego } \\
\text { lub własnej), list oficjalny, proste } \\
\text { sprawozdanie (np. z wycieczki, z wydarzeń } \\
\text { sportowych), opis postaci, przedmiotu, } \\
\text { krajobrazu, ogłoszenie, zaproszenie, prosta } \\
\text { notatka. }\end{array}$ \\
\hline \multicolumn{2}{|l|}{ III. Tworzenie wypowiedzi. } \\
\hline $\begin{array}{l}\text { 1) tworzy spójne wypowiedzi w następujących } \\
\text { formach gatunkowych: recenzja, rozprawka, } \\
\text { podanie, życiorys, CV, list motywacyjny, prze- } \\
\text { mówienie, wywiad. }\end{array}$ & \\
\hline
\end{tabular}




\begin{tabular}{l} 
WIEDZA O SPOŁECZEŃSTWIE \\
\hline I. 2) przedstawia zasady komunikowania się; \\
wyjaśnia zasady skutecznej autoprezentacji- \\
kształtowania swojego wizerunku.
\end{tabular}

I. 3) wymienia cechy grup społecznych; charakteryzuje grupę koleżeńską i grupę nastawioną na realizację określonego zadania; uzasadnia, że efektywna współpraca przynosi różne korzyści; przedstawia różne formy współpracy w grupie.

I. 6) uzasadnia, że konflikt w grupie może wynikać z różnych przyczyn (sprzeczne interesy, inne cele); przedstawia sposoby rozwiązywania konfliktów oraz analizuje ich zalety i wady.

II. 3) wyjaśnia, jak funkcjonuje gospodarstwo domowe; wymienia główne źródła jego dochodów (z działalności zarobkowej: pracy, działalności gospodarczej, umów cywilnoprawnych oraz ze świadczeń społecznych - w powiązaniu z rodzajami ubezpieczeń społecznych).

II. 4) wymienia kategorie wydatków gospodarstwa domowego; planuje jego budżet.

III. 4) charakteryzuje oczekiwane kompetencje wybranych kategorii społeczno-zawodowych i ich miejsce na rynku pracy;

III. 5) planuje dalszą edukację, uwzględniając własne zainteresowania, zdolności i umiejętności oraz rady innych osób i sytuację na rynku pracy.

VI. 1) wymienia zadania samorządu gminnego; przedstawia główne źródła przychodów i kierunki wydatków w budżecie gminy.

IX. 1) podaje cnoty obywatelskie (odpowiedzialność, troska o dobro wspólne, aktywność, przedsiębiorczość, solidarność, roztropność, tolerancja, odwaga cywilna); wykazuje, odwołując się do działań wybitnych Polaków, znaczenie ich urzeczywistnienia dla pożytku publicznego.

X. 3) przedstawia funkcje reklamy i krytycznie analizuje wybrany przekaz reklamowy.

\section{HISTORIA I SPOKECZEŃSTWO}

3) wyjaśnia znaczenie rodziny w życiu oraz wskazuje przykłady praw i obowiązków przysługujących poszczególnym członkom rodziny.

\begin{tabular}{l|l}
\hline & $\begin{array}{l}\text { 1.5) charakteryzuje społeczność szkolną, } \\
\text { z uwzględnieniem swoich praw i obowiązków. }\end{array}$ \\
\hline & $\begin{array}{l}\text { 2.1) opisuje swoją "małą ojczyznę”, uwzględ- } \\
\text { niając tradycję historyczno-kulturową i proble- } \\
\text { my społeczno-gospodarcze. }\end{array}$ \\
\hline $\begin{array}{l}\text { 2. 3) wskazuje na planie miejscowości, siedzibę } \\
\text { władz lokalnych i na przykładach omawia za- } \\
\text { kres działań oraz sposoby powoływania władz. }\end{array}$
\end{tabular}


1. 3) podaje przykłady praw i obowiązków obywateli Rzeczypospolitej Polskiej.

5. 1) wyjaśnia znaczenie pracy w życiu człowieka i dostrzega jej społeczny podział.

25. 4) opisuje warunki pracy w XIX-wiecznej fabryce.

\section{GEOGRAFIA}

X. 7) wykazuje znaczenie poszczególnych sektorów gospodarki w rozwoju kraju oraz określa różnice $w$ strukturze zatrudnienia ludności w Polsce i w wybranych państwach europejskich.

X. 8) porównuje wielkość bezrobocia w Polsce i innych krajach europejskich oraz określa jego przyczyny i skutki w Polsce.

X. 13) podaje przykłady różnych rodzajów usług w Polsce oraz ocenia znaczenie transportu i łączności dla jakości życia mieszkańców i rozwoju gospodarczego naszego kraju.

X. 16) podaje przykłady osiągnięć Polaków w różnych dziedzinach życia społeczno-gospodarczego oraz sukcesów polskich przedsiębiorstw na arenie międzynarodowej.

X. 17) jest świadomy tego, że może mieć w przyszłości wpływ na rozwój społeczno-gospodarczy i kulturowy Polski.

XI. 6) identyfikuje związki między przebiegiem autostrad i dróg ekspresowych a lokalizacją przedsiębiorstw przemysłowych, centrów logistycznych i handlowych w obszarze metropolitalnym Wrocławia oraz między transportem morskim a lokalizacją inwestycji przemysłowych i usługowych na przykładzie Trójmiasta.

XIII. 3) przedstawia w dowolnej formie (np. prezentacji multimedialnej, plakatu, filmu, wystawy fotograficznej) atrakcyjność "małej ojczyzny" jako miejsca zamieszkania i działalności gospodarczej na podstawie informacji wyszukanych w różnych źródłach.

\section{Geografia nie występowała w szkole podsta-} wowej.

\begin{tabular}{l|l}
\hline \multicolumn{2}{c}{ MATEMATYKA } \\
\hline $\begin{array}{l}\text { Klasy VII-VIII: } \\
\begin{array}{l}\text { V. 5) stosuje obliczenia procentowe do rozwią- } \\
\text { zywania problemów w kontekście praktycznym, } \\
\text { również w przypadkach wielokrotnych podwy- } \\
\text { żek lub obniżek danej wielkości. }\end{array}\end{array}$ \\
\hline \multicolumn{1}{c|}{ INFORMATYKA } & \multicolumn{1}{c}{ ZAJĘCIA KoMPUTEROWE } \\
\hline $\begin{array}{l}\text { Klasy IV-VI: } \\
\begin{array}{l}\text { IV. 2) identyfikuje i docenia korzyści płynące } \\
\text { ze współpracy nad wspólnym rozwiązywaniem } \\
\text { problemów. }\end{array}\end{array}$ & $\begin{array}{l}\text { 5.2) uczestniczy w pracy zespołowej, porozu- } \\
\text { miewa się z innymi osobami podczas realizacji } \\
\text { wspólnego projektu, podejmuje decyzje w za- } \\
\text { kresie swoich zadań i uprawnień. }\end{array}$ \\
\hline
\end{tabular}


IV. 4) określa zawody i wymienia przykłady z życia codziennego, w których są wykorzystywane kompetencje informatyczne.

4. 2) opracowuje i redaguje teksty (listy, ogłoszenia, zaproszenia, ulotki, wypracowania), stosując podstawowe możliwości edytora tekstu w zakresie formatowania akapitu i strony, łączy grafikę z tekstem.

Klasa VII-VIII:

IV. 4) określa zakres kompetencji informatycznych, niezbędnych do wykonywania różnych zawodów, rozważa i dyskutuje wybór dalszego i pogłębionego kształcenia, również w zakresie informatyki.

\section{TECHNIKA}

I. 5) współpracuje i podejmuje różne role w pracy w zespole.

\section{WYCHOWANIE DO ŻYCIA W RODZINIE}

VI. 3) radzi sobie w sytuacji konfliktu, presji grupy, stresu.

VI. 4) zna i stosuje zasady savoir-vivre'u w róż3. Więź rodzinna, związki uczuciowe i inne relanych sytuacjach społecznych. cje $w$ rodzinie; konflikty i ich rozwiązywanie.

VI. 5) rozumie zasady komunikacji werbalnej i niewerbalnej $\mathrm{i}$ jej znaczenie $\mathrm{w}$ relacjach interpersonalnych; przyjmuje odpowiedzialność za manifestowane reakcje, wypowiadane i pisane słowa.

VI. 6) kształtuje i wyraża postawy asertywne, gdy nie może lub nie powinien czegoś wykonać, stara się odmawiać tak, by nie ranić drugiego.

VI. 7) bierze udział w życiu społecznym przez: wolontariat, stowarzyszenia, grupy nieformalne i aktywność indywidualną; ujawnia wrażliwość na osoby potrzebujące pomocy i zna konkretne sposoby jej udzielania.

\begin{tabular}{l|l}
\hline \multicolumn{2}{c}{ ETYKA } \\
\hline $\begin{array}{l}\text { III. 3) zna i rozwija swoje zalety, rozpoznaje } \\
\text { i eliminuje swoje wady. }\end{array}$ \\
\hline $\begin{array}{l}\text { III. 4) zna swoje podstawowe prawa i obo- } \\
\text { wiązki (ucznia, dziecka) oraz wypełnia własne } \\
\text { obowiązki. }\end{array}$ \\
\hline \multicolumn{2}{c}{ JęZYK MNIEJSzoścı NARODOWEJ LUB ETNICZNEJ } \\
\hline
\end{tabular}

3. 5) identyfikuje wypowiedź jako tekst reklamowy, informacyjny.
2. 5) identyfikuje wypowiedź jako tekst literacki, reklamowy, informacyjny.

Źródło: Opracowanie własne na podstawie Rozporządzenia MEN... $(2012,2017)$. 
Porównanie podstaw programowych w starszych klasach szkoły podstawowej nie jest sprawą prostą, co wynika ze zmiany całego systemu szkolnego w wyniku reformy. W konsekwencji tych zmian zlikwidowano gimnazja, wydłużono edukację w szkole podstawowej z sześciu do ośmiu klas, a w liceum i technikum - o rok kształcenia. Należy więc zauważyć, że zagadnienia związane z przedsiębiorczością w podstawie programowej na trzecim etapie edukacyjnym (gimnazjum) w poprzedniej podstawie programowej były zapisane w kilku przedmiotach, głównie w wiedzy o społeczeństwie i języku polskim. Część z nich została uwzględniona w zapisach podstawy programowej dla nowej, ośmioklasowej szkoły podstawowej lub przeniesiona do szkoły średniej, które zyskały dodatkowy rok na realizację tych treści. W poprzedniej podstawie programowej dla przedmiotu język polski były zapisane efekty związane z odbieraniem komunikatów i tworzeniem spójnych wypowiedzi ustnych i pisemnych (w tym w formie życiorysu, CV i listu motywacyjnego).

Głównym przedmiotem rozwijającym kompetencje przedsiębiorcze i dającym podstawy wiedzy ekonomicznej w ramach byłego gimnazjum była wiedza o społeczeństwie. Zapisy w poprzedniej podstawie programowej z tego zakresu były przedmiotem wcześniejszego zainteresowania badaczy i poddano je szczegółowej analizie (Kurek, Rachwał 2010, Kurek, Rachwał, Szubert 2012, Berger i in. 2012, Rachwał, Kurek, Boguś 2016). Należy jednak w tym miejscu zaznaczyć, że zapisano w niej wiele treści odnoszących się do przedsiębiorczości. Jak wskazały jednak badania w środowisku szkolnym (Kurek, Rachwał, Szubert 2012), bardzo często były one w praktyce edukacyjnej marginalizowane przez nauczycieli wiedzy o społeczeństwie. Wynikało to z wielu przyczyn, wśród których najważniejsze to brak przygotowania nauczycieli tego przedmiotu do realizacji treści ekonomiczno-biznesowych czy finansowych oraz brak czasu na realizację zbyt rozbudowanej podstawy programowej. Niemniej w podstawie programowej wiedzy o społeczeństwie formalnie występowało wiele zapisów wymagań szczegółowych związanych z przedsiębiorczością,w następujących działach (grupach treści kształcenia):

$\rightarrow$ Podstawowe umiejętności życia w grupie (w tym głównie efekty związane z komunikacją interpersonalną oraz podejmowaniem decyzji).

$\rightarrow$ Praca i przedsiębiorczość (efekty związane głównie z cechami osoby przedsiębiorczej oraz zasadami organizacji pracy). 
$\rightarrow$ Gospodarka rynkowa (poznanie podmiotów gospodarki, zasad racjonalnego gospodarowania, cech gospodarki rynkowej i działania popytu i podaży).

$\rightarrow$ Gospodarstwo domowe (jak funkcjonuje, jak układa się jego budżet, prawa konsumenta).

$\rightarrow$ Pieniądz i banki (w tym funkcje i formy pieniądza, wybrane instytucje finansowe, oferta usług bankowych).

$\rightarrow$ Gospodarka w skali państwa (w tym wskaźniki gospodarcze, budżet państwa, podatki).

$\rightarrow$ Przedsiębiorstwo i działalność gospodarcza (w tym efekty dotyczące wyjaśnienia, na czym polega prowadzenie indywidualnej działalności gospodarczej i jak "działa przedsiębiorstwo", jakie są elementy działań marketingowych oraz główne prawa i obowiązki pracownika, a także czemu służą ubezpieczenia społeczne i zdrowotne).

$\rightarrow$ Wybór szkoły i zawodu (w tym planowanie własnej edukacji, wyszukiwanie informacji o możliwościach zatrudnienia, sporządzanie życiorysu i listu motywacyjnego, przyczyny bezrobocia i ocenianie jego skutków).

$\rightarrow$ Etyka w życiu gospodarczym (w tym społeczna odpowiedzialność biznesu, szara strefa i korupcja w życiu społeczno-gospodarczym).

Może się wydawać, że treści te zniknęły z wiedzy o społeczeństwie wraz z likwidacją gimnazjum. Tak się jednak nie stało. Część z nich, związanych głównie z przedsiębiorczością jako postawą człowieka, komunikacją interpersonalną i budżetami gospodarstw domowych, została włączona do wiedzy o społeczeństwie w VIII klasie szkoły podstawowej, a pozostałe przeniesiono do szkoły średniej albo $w$ ramach tego przedmiotu (np. ubezpieczenia społeczne i budżet państwa bądź jednostek samorządu terytorialnego), albo $w$ ramach podstaw przedsiębiorczości (o czym szerzej będzie mowa w innym opracowaniu ujętym w niniejszym tomie).

Warto zwrócić także uwagę, że zgodnie z wcześniejszymi postulatami środowisk naukowych i oświatowych związanych z edukacją w zakresie przedsiębiorczości (zob. Rachwał 2017) wyeliminowano występujące wcześniej zbędne powtórzenia zapisów efektów w gimnazjum i szkole średniej, porządkując nieco te treści oraz urealniając 
możliwości realizacji efektów kształcenia w ramach wiedzy o społeczeństwie i podstaw przedsiębiorczości. Usunięto także nieprecyzyjne zapisy, co do których nauczyciel miał wątpliwości, na przykład "[uczeń] wyjaśnia, jak działa przedsiębiorstwo" można interpretować zarówno bardzo wąsko, jak i bardzo szeroko. Był to również jeden z postulatów nauczycieli przedsiębiorczości (Rachwał 2017).

W warunkach poprzedniej podstawy programowej edukację w zakresie przedsiębiorczości wspierała geografia. Zagadnienie to było przedmiotem wcześniejszej szczegółowej analizy Moniki Borowiec i Tomasza Rachwała (2011). Rola geografii w tym zakresie, jak się wydaje, wzrosła - ze względu na włączenie w większym zakresie treści z dziedziny geografii społeczno-ekonomicznej. Warto także zwrócić uwagę, że do podstawy programowej historii w większym stopniu niż dotychczas wprowadzono zapisy odnoszące się do historii gospodarczej, co sprzyja późniejszemu kształtowaniu umiejętności rozumienia procesów zachodzących współcześnie w gospodarce w ramach lekcji geografii i podstaw przedsiębiorczości w szkole średniej.

\section{Zakończenie}

Analiza zapisów nowej podstawy programowej wychowania przedszkolnego i kształcenia ogólnego w ośmioletniej szkole podstawowej wskazuje, że utrzymano i nieco rozszerzono dotychczasowe zapisy odnoszące się do wiedzy ekonomiczno-finansowej oraz kształtowania umiejętności i postaw związanych z przedsiębiorczością. Zgodnie z postulatami wielu nauczycieli, specjalistów, badaczy i propagatorów edukacji ekonomicznej niektóre zapisy pojawiają się na wcześniejszych etapach kształcenia. Przykładem są elementy edukacji finansowej związanej z rolą pieniądza (głównie w życiu rodziny) i wykonywaniem pracy w różnych zawodach na poziomie edukacji wczesnoszkolnej.

Przyjęto ponadto założenie, że umiejętności w zakresie komunikacji interpersonalnej powinny być już w znacznym stopniu ukształtowane na etapie szkoły podstawowej, dlatego nie są one w zakresie elementarnym powtarzane na etapie szkoły średniej. Choć na etapie szkoły podstawowej nie jest realizowany przedmiot podstawy przedsiębiorczości, to jednak zapisy dotyczące przedsiębiorczości występują $w$ wielu przedmiotach szkolnych. Tym samym można uznać, że zapisy nowej podstawy programowej sprzyjają postulatom wielu autorów (Oeszlaeger-Kosturek 2017, Rachwał 2017, Raszka 2017, Zioło 2012), 
przynajmniej częściowo wypełniając luki w przestrzeni edukacyjnej w tym zakresie, na który zwrócił uwagę Tomasz Kopczyński (2017).

Należy jednak zaznaczyć, że nawet najlepsze zapisy podstawy programowej nie gwarantują, że efekty kształcenia w zakresie przedsiębiorczości będą osiągane w zadowalającym stopniu. Niezbędni w tym procesie są kompetentni nauczyciele różnych przedmiotów, rozumiejący istotę kształtowania postaw przedsiębiorczych dzieci i młodzieży. 


\section{Bibliografia}

$\rightarrow$ Berger, S., Canning, R., Dolan, M., Kurek, S., Pilz, M., Rachwał, T. (2012), Curriculum-making in pre-vocational education in the lower secondary school: A regional comparative analysis within Europe, „Journal of Curriculum Studies”, nr 44 (5), s. 679-701.

$\rightarrow$ Borowiec, M., Rachwał, T. (2011), Kształtowanie postaw przedsiębiorczych na lekcjach geografii wyzwaniem edukacyjnym w procesach globalizacji, „Przedsiębiorczość - Edukacja", nr 7, s. 321-332.

$\rightarrow$ Kopczyński, T. (2017), Brakujq̨ce elementy kształtowania przedsiębiorczości w przestrzeni edukacyjnej [w:] A. Murzyn, U. Szuścik (red.), Przedsiębiorczość jako wartość edukacji, Katowice: Wydawnictwo Uniwersytetu Śląskiego, s. 83-93.

$\rightarrow$ Kurek, S., Rachwał, T. (2010), Założenia i wstępne wyniki europejskiego projektu badawczego "FIFOBI" w zakresie kształtowania kompetencji uczniów gimnazjum do prowadzenia działalności gospodarczej, „Przedsiębiorczość-Edukacja”, nr 6, s. 472-485.

$\rightarrow$ Kurek, S., Rachwał, T., Szubert, M. (2012), Business Competencies in Polish School Curricula: Opinions of Teachers and Social Partners [w:] M. Pilz, S. Berger, R. Canning (red.), Fit for Business. Pre-Vocational Education in European Schools, Wiesbaden: VS Verlag für Sozialwissenschaften, Springer, s. 61-88.

$\rightarrow$ Oeszlaeger-Kosturek, B. (2017), Przedsiębiorczość - istota i sposoby kształtowania w procesie edukacji wczesnoszkolnej [w:] A. Murzyn, U. Szuścik (red.), Przedsiębiorczość jako wartość edukacji, Katowice: Wydawnictwo Uniwersytetu Śląskiego, s. 154-166.

$\rightarrow$ Rachwał, T. (2005), Kształtowanie postaw uczniów na lekcjach podstaw przedsiębiorczości, „Przedsiębiorczość - Edukacja”, nr 1, s. 137-144.

$\rightarrow$ Rachwał, T. (2006), Kształtowanie postaw przedsiębiorczych w edukacji szkolnej [w:] B. Muchacka (red.), Szkoła w nauce i praktyce edukacyjnej, t. 2, Kraków: Oficyna Wydawnicza „Impuls", Akademia Pedagogiczna w Krakowie, s. 427-434. 
$\rightarrow$ Rachwał, T. (2017), Entrepreneurship in School in the Conditions of the Education System Reform in Poland - a Voice in the Discussion on the Directions of Change, „Przedsiębiorczość - Edukacja”, 1nr 3, s. 330-339.

$\rightarrow$ Rachwał, T., Kurek, S., Boguś, M. (2016), Entrepreneurship Education at Secondary Level in Transition Economies: A Case of Poland, „Entrepreneurial Business and Economics Review", nr 4 (1), s. 61-81.

$\rightarrow$ Raszka, R. (2017), Edukacja finansowa dzieci [w:] A. Murzyn, U. Szuścik (red.), Przedsiębiorczość jako wartość edukacji, Katowice: Wydawnictwo Uniwersytetu Śląskiego, s. 140-153.

$\rightarrow$ Rozporządzenie MEN... (2012), Rozporządzenie Ministra Edukacji Narodowej z dnia 27 sierpnia 2012 r. w sprawie podstawy programowej wychowania przedszkolnego oraz kształcenia ogólnego w poszczególnych typach szkół (Dz.U. 2012, poz. 977).

$\rightarrow$ Rozporządzenie MEN... (2017), Rozporządzenie Ministra Edukacji Narodowej z dnia 14 lutego 2017 r. w sprawie podstawy programowej wychowania przedszkolnego oraz podstawy programowej kształcenia ogólnego dla szkoły podstawowej, w tym dla uczniów z niepełnosprawnością intelektualną w stopniu umiarkowanym lub znacznym, kształcenia ogólnego dla branżowej szkoły I stopnia, kształcenia ogólnego dla szkoły specjalnej przysposabiającej do pracy oraz kształcenia ogólnego dla szkoły policealnej (Dz.U. 2017, poz. 356).

$\rightarrow$ Tracz, M. (2006), Rola i znaczenie „podstaw przedsiębiorczości” w kształceniu ogólnym, „Przedsiębiorczość - Edukacja”, nr 2, s. 222-225.

$\rightarrow$ Tracz, M. (2015), Przedmiot podstawy przedsiębiorczości w opinii uczniów i nauczycieli - studium porównawcze, „Przedsiębiorczość - Edukacja”, nr 11, s. 391-400.

$\rightarrow$ Wach, K. (2013), Edukacja na rzecz przedsiębiorczości wobec współczesnych wyzwań cywilizacyjno-gospodarczych, „Przedsiębiorczość - Edukacja”, nr 9, s. 246-257.

$\rightarrow$ Wach, K. (2014), Edukacja dla przedsiębiorczości: pomiędzy przedsiębiorcza pedagogikq a edukacjq ekonomicznq i biznesowq, "Horyzonty Wychowania", nr 13 (28), s. 11-31.

$\rightarrow$ Wollman, L. (2015), Rozwijanie potencjału uczenia się w ujęciu Guya Claxtona [w:] J. Uszyńska-Jarmoc, M. Bilewicz (red.), Kompetencje kluczowe dzieci i młodzieży. Teoria i badania, Warszawa: Wydawnictwo Akademickie Żak, s. 97-108.

$\rightarrow$ Wollman, L. (2017), Przedsiębiorczość w procesie uczenia się w koncepcji Guya Claxtona [w:] A. Murzyn, U. Szuścik (red.), Przedsiębiorczość jako wartość edukacji, Katowice: Wydawnictwo Uniwersytetu Śląskiego, s. 128-139.

$\rightarrow$ Zioło, Z. (2012), Miejsce przedsiębiorczości w edukacji, „Przedsiębiorczość - Edukacja", nr 8, s. 10-23. 


\section{Wolontariat szkolny jako narzędzie rozwoju kompetencji przedsiębiorczych}

Renata Rettinger

Wolontariat i inne formy działalności altruistycznej są ważnymi elementami kształtowania kluczowych kompetencji oraz uniwersalnych umiejętności niezbędnych do funkcjonowania na rynku pracy. W artykule przedstawiona zostanie działalność wolontariacka jako czynnik warunkujący kształtowanie i rozwój postaw przedsiębiorczych dzieci oraz młodzieży w szkole podstawowej. Obecnie edukacja szkolna opiera się na pewnym systemie schematów (reguł), a tym samym może ograniczać przedsiębiorczość i innowacyjność uczniów. Dlatego aktywność uczniowska w wolontariacie szkolnym może być sposobem na kształtowanie tych kompetencji.

\section{__ Słowa kluczowe: \\ kompetencje \\ postawa przedsiębiorcza \\ szkoła podstawowa \\ wolontariat}




\section{The school volunteering \\ as a tool for developing the \\ entrepreneurial competencies}

Renata Rettinger

In recent years, volunteering is getting more and more popular. Volunteering or other altruistic activity are an important element in shaping key competencies and universal skills necessary for functioning on the labour market. Here the closer look on volunteering in school will be taken. The main aim of the study is to analyse voluntary activities as a factor conditioning shaping and developing entrepreneurial attitudes of children and youth in primary school. Current school education is guided by a certain system of schemes (rules), and thus may limit the entrepreneurship and innovativeness of students. Therefore the activity of students in school volunteering can be the way to shape these competences.

\section{Keywords:}

competences

entrepreneurial attitude

primary school

volunteering 


\section{Wprowadzenie}

W literaturze przedmiotu istnieje wiele definicji określających, co to są przedsiębiorczość czy kompetencje przedsiębiorcze. Na potrzeby niniejszego opracowania przyjęto, że jest to zespół cech osobowości, takich jak inicjatywność, kreatywność, energia i zapał do pracy, wytrwałość w działaniu, a także ciekawość świata, pewność siebie i wiara we własne siły, samodyscyplina, skłonność do podejmowania wyważonego ryzyka i branie odpowiedzialności za siebie i innych (Rachwał 2005; Strojny 2007; Piróg 2015).

W preambule Podstawy programowej kształcenia ogólnego dla zreformowanej szkoły podstawowej zapisano: „[...] kształcenie ogólne w szkole podstawowej ma na celu: [...] rozwijanie kompetencji takich jak: kreatywność, innowacyjność i przedsiębiorczość". Chodzi tutaj bardziej o realizację tego procesu w ramach innych przedmiotów, nie zaś bezpośrednio poprzez nauczanie konkretnych treści (por. Rachwał i in. 2018). Zadaniem edukacji jest przygotowanie ludzi do adaptacji w nowych uwarunkowaniach społeczno-gospodarczych, tak aby mogli oni w sposób racjonalny wpływać na struktury, które dziś podlegają przemianom (Borowiec, Rachwał 2011). Postawy przedsiębiorcze powinny być kształtowane przez polską szkołę już od pierwszego roku edukacji wczesnoszkolnej, i to na wszystkich zajęciach, bo to warunkuje ich pełne i satysfakcjonujące uczestnictwo w życiu społeczno-gospodarczym w przyszłości (Rachwał i in. 2018; Rachwał, Wach 2016; Piróg 2015).

W kontekście edukacji i kształcenia najczęściej przytaczana jest definicja przedsiębiorczości jako zdolności osoby do wcielania pomysłów w czyn, nawiązująca do definicji przyjętej przez Komisję Europejską (Borowiec, Kilar, Rachwał 2018; Wach 2013). Obejmuje ona: twórczość, innowacyjność i podejmowanie ryzyka, a także zdolność do planowania przedsięwzięć i prowadzenia ich dla osiągnięcia zamierzonych celów. Edukacja w zakresie przedsiębiorczości odgrywa kluczową rolę w budowaniu przedsiębiorczego społeczeństwa i przedsiębiorczej gospodarki.

Wydaje się zasadne stwierdzenie, że w ramach krajowego systemu oświaty przyjęto zasadę edukacji „o" przedsiębiorczości i „dla" przedsiębiorczości, nie zaś „przez" przedsiębiorczość. Oczywiście podstawa programowa na każdym etapie kształcenia przewiduje realizację różnych przedmiotów z wykorzystaniem innowacyjnych, aktywnych metod nauczania. Zakłada też, że najlepszą metodą jest tzw. learning by doing, jednak wprowadzenie w życie takich zaleceń jest bardzo trudne (Bień- 
kowska 2017). W związku z tym należy wykorzystywać inne momenty życia szkolnego do kształcenia kompetencji, takich jak kreatywność, przedsiębiorczość i innowacyjność. Miejscem na tego typu działania może być szkolny wolontariat. Dzięki temu zostanie wykreowana możliwość nabywania takich kompetencji łącznie, na każdym etapie i niezależnie od wieku uczniów (tamże).

Jednocześnie wiele wskazuje na to, że uczniowie polskich szkół nie mają realnej możliwości rozwoju kompetencji w zakresie inicjatywności i przedsiębiorczości w ramach nauki szkolnej. Młodzi Polacy w szkole podstawowej mogą co prawda zdobyć odpowiednią wiedzę w tym zakresie, natomiast nie mają możliwości rozwoju umiejętności i odpowiednich postaw z tym związanych. Barierą rozwoju tych kompetencji są: kultura panująca w polskich szkołach, ograniczenie autonomii uczniów oraz sposób nauczania, który pomija rozwój umiejętności i postaw (Atroszko 2015). Teoretycznie uczniowie polskich szkół mogą podejmować różnorodne inicjatywy w ramach samorządu uczniowskiego. Faktycznie jednak jest to instytucja fasadowa, niemająca rzeczywistego wpływu na to, co się dzieje w szkole. Istnienie i funkcjonowanie tej instytucji można określić jako działanie pozorne (Atroszko 2015). W ostatnich latach pojawiło się wiele projektów w przestrzeni szkoły podstawowej, które mają na celu podnoszenie kompetencji uczniów w zakresie przedsiębiorczości, tworzenia pomysłów biznesowych, myślenia projektowego, kreatywności i projektowania oraz komunikacji. Jednym z takich pomysłów są spółdzielnie uczniowskie, zyskujące z każdym rokiem większą popularność wśród uczniów i nauczycieli.

Przedsiębiorczość, innowacyjność, kreatywność - to trzy pojęcia, które pojawiają się współcześnie we wszystkich dyskusjach na temat najbardziej pożądanych kompetencji na współczesnym rynku pracy oraz w kontekście najważniejszych determinant wzrostu i rozwoju gospodarczego. Kompetencje można określić jako sumę posiadanej wiedzy, umiejętności praktycznych i postaw, które przejawia dana osoba. Być przedsiębiorczym to znaczy zdobywać i rozwijać kompetencje istotne społecznie oraz korzystać z nich w sposób pozwalający na osiągnięcie sukcesu własnego lub społecznego/obywatelskiego. 


\section{Wolontariat jako forma składowa edukacji}

\section{i kształcenia w zakresie przedsiębiorczości}

Jednym z najważniejszych celów kształcenia w szkole podstawowej jest dbałość o integralny rozwój biologiczny, poznawczy, emocjonalny, społeczny i moralny ucznia. Rozwój ten powinien być realizowany nie tylko przez system obowiązkowych zajęć lekcyjnych określonych w podstawie programowej, lecz także przez inne pozalekcyjne formy aktywności szkolnej. Jedną z takich form jest szkolny wolontariat, który działa praktycznie w każdej polskiej szkole podstawowej. Jego funkcjonowanie powinno być sformalizowane i w pełni kontrolowane przez dyrekcję oraz grono pedagogiczne. Wolontariat to bezpłatne, dobrowolne, świadome działanie ucznia, studenta na rzecz innych, wykraczające poza więzi rodzinno-koleżeńsko-przyjacielskie (Górniak 2013). Wolontariat musi wynikać z motywacji człowieka do tego rodzaju aktywności.

Ustawa o pożytku publicznym i wolontariacie reguluje prawne uwarunkowania oraz klasyfikuje organizacje i instytucje prowadzące tego typu działalność, nazywając je korzystającymi:

$\rightarrow$ organizacje pozarządowe - przede wszystkim stowarzyszenia i fundacje,

$\rightarrow$ stowarzyszenia jednostek samorządu terytorialnego, np. związki gmin lub powiatów,

$\rightarrow$ osoby prawne i jednostki organizacyjne Kościoła katolickiego i innych Kościołów lub związków wyznaniowych, np. parafie, zakony,

$\rightarrow$ organy administracji publicznej - centralnej i samorządowej,

$\rightarrow$ jednostki organizacyjne podległe organom administracji publicznej lub nadzorowane przez te organy.

Rola szkoły, a w szczególności dyrekcji i grona pedagogicznego, polega na umożliwieniu podejmowania takich inicjatyw oraz wspieraniu ich działań finansowo i organizacyjnie. Pedagodzy pracujący z uczniami w ramach wolontariatu powinni stworzyć warunki sprzyjające głównej idei wolontariatu, którą jest pomaganie. Zatem rolą nauczycieli jest tworzenie atmosfery i środowiska do rozwijania kompetencji uczniowskich poprzez wachlarz inicjatyw charytatywnych. Warto też dodać, że również rodzice powinni wspierać swoje dzieci w działaniach na rzecz innych. Wsparcie nie powinno polegać na prześciganiu się w kwocie pomocy finansowej lub rzeczowej, ale na zachęcaniu do działania na 
rzecz innych. Motywy, którymi mogą kierować się wolontariusze, podejmując tego typu działania, są przede wszystkim osobiste, związane z satysfakcją z pracy (Załuska 1996). Badania wskazują, że są to: chęć pomagania innym, potrzeba serca, brak innego pożytecznego zajęcia oraz nabycie nowych umiejętności. Na podstawie dostępnej literatury przedmiotu można dokonać klasyfikacji motywów, którymi kierują się uczniowie podejmujący działania dla innych:

$\rightarrow$ poparcie określonych wartości lub idei-działania podejmowane dla zabezpieczenia potrzeb społecznie uznawanych za słuszne, np. pomoc humanitarna w sytuacjach trudnych zarówno dla ludzi, jak i zwierząt,

$\rightarrow$ chęć kreowania własnej, pozytywnej pozycji w społeczności szkolnej - działania zmierzające do stworzenia obrazu własnej osoby zgodnego z wizerunkiem powszechnie uznawanym i bardzo cenionym, czyli typem społecznika,

$\rightarrow$ chęć zaspokojenia własnych ambicji - działalność przynosząca osobie satysfakcję życiową, poczucie spełnienia oraz samorealizacji, możliwość wyrażania własnych poglądów, wcielanie w życie autorskich projektów.

Bardzo ważnym aspektem pracy jako wolontariusza jest zorientowanie na praktykę, czyli przygotowanie do wykonywania działań zmierzających do osiągnięcia celu. Nie wystarcza, by idea pomocy i współdziałania rozpowszechniała się $w$ teorii, tu praktyczne działania muszą iść w parze z teorią, nabierając realnego kształtu (Roguska 2010). Praktyka, działanie mają tu znaczenie pierwszoplanowe, ponieważ idea pomocy innym opiera się na działaniu, jest to urzeczywistnianie zamysłów w działaniu.

Współcześnie wolontariat nie oznacza wyłącznie „zbiórki pieniędzy do puszki". Działalność wolontariacka wymaga uruchomienia pokładów kreatywności, innowacyjności i przedsiębiorczości uczniowskiej w planowaniu, organizowaniu i przeprowadzaniu imprez charytatywnych mających na celu zebranie pieniędzy lub przedmiotów. Należy podkreślić, że w działania szkolnego wolontariatu mogą włączyć się wszystkie grupy dzieci i młodzieży w szkole podstawowej - wiek może mieć jedynie wpływ na role czy pozycję w zespole. W przypadku młodszych dzieci ważną rolę odgrywa uświadomienie, że mają one szansę działać i wykazać się kompetencjami przedsiębiorczymi, że ich 
pomysły są ważne i mogą zostać zrealizowane. Zwiększanie zasięgu imprez charytatywnych wymaga od uczniów kreatywności w tworzeniu pomysłu, w jaki sposób można zebrać środki, to uruchamia postawy przedsiębiorcze.

\section{Korzyści kompetencyjne związane}

\section{z działalnością $w$ wolontariacie}

Najważniejsze umiejętności, które zdobywają uczniowie w ramach tej działalności, to:

$\rightarrow$ praca $z$ grupą i praca w zespole,

$\rightarrow$ pewność siebie,

$\rightarrow$ odwaga,

$\rightarrow$ rozwój kompetencji interpersonalnych,

$\rightarrow$ umiejętność wystąpień publicznych.

Wolontariat może więc być świadectwem człowieka z pasją, która daje mu przewagę na rynku pracy. Ideą wolontariatu jest pomaganie potrzebującym, w związku z tym kształtowanie umiejętności poprzez ten rodzaj działalności ma charakter wtórny. Rozwój młodego człowieka następuje tu przez "dawanie siebie" innym i to daje przewagę wolontariatowi nad innymi formami rozwoju (praktyki, szkolenia). Robiąc coś dla innych, wolontariusze doświadczają głębszych uczuć, co stymuluje ich kompleksowy rozwój. Wolontariat $w$ tym rozumieniu staje się formą świadomego i aktywnego uczestnictwa w społeczeństwie obywatelskim, a wolontariusze to osoby, które podejmując decyzję o pracy charytatywnej, robią to w sposób świadomy i odpowiedzialny.

$W$ trakcie realizacji zadań $w$ ramach szkolnego wolontariatu uczniowie mają możliwość kształtowania tzw. kompetencji miękkich, takich jak: efektywna komunikacja, otwartość na uczenie się i rozwój, zaangażowanie, umiejętność pracy w zespole, umiejętność określania priorytetów, etyczne postępowanie, odpowiedzialność, umiejętność organizacji pracy i efektywnego zarządzania czasem oraz elastyczność i zdolność adaptacji. Można je uznać za kompetencje uniwersalne (Kulig-Moskwa 2013). Należy pamiętać, że pracodawcy chętniej angażują absolwentów aktywnych, z pasją i doświadczeniem w działalności uczniowskiej, studenckiej, społecznej i sportowej. W dalszym ciągu zauważa się brak kompetencji samoorganizacyjnych, a zatem takich cech jak: samodzielność, przedsiębiorczość, przejawianie inicjatywy, odporność na stres, 
motywacja do pracy (tamże). Wolontariat może po części wypełnić tę lukę. Rywalizacja i stawianie przed uczniami wyzwań to dobry sposób na aktywizację i nauczanie przez przedsiębiorczość oraz realizację celów użytecznych społecznie. Postawa przedsiębiorcza powinna być ważnym efektem nauki i socjalizacji w szkole.

Wolontariat pomaga młodym ludziom w byciu kreatywnym, pewnym siebie i zachowaniu się w sposób odpowiedzialny społecznie, a także pozwala na kształtowanie takich postaw wśród uczniów jak: „uczciwość, odpowiedzialność, poczucie własnej wartości, przedsiębiorczość, gotowość do podejmowania inicjatyw pracy zespołowej, postawa obywatelska". Aby zostać wolontariuszem, trzeba liczyć się z tym, że nie polega to tylko na pracy dla kogoś i pomaganiu. Osoby, które chcą zajmować się wolontariatem, muszą zdawać sobie sprawę, że będą im stawiane różne wymagania. Praca charytatywna wymaga poświęcenia. W ten sposób nasuwa się kolejny wniosek: decydując się na pracę dla innych, tych, którzy potrzebują pomocy, robimy także coś dla siebie. Nie tylko stajemy się lepszymi ludźmi, lecz także uczymy się nowych rzeczy, nabywamy nowe umiejętności i doskonalimy te już posiadane. Wolontariat $w$ tym rozumieniu staje się formą świadomego i aktywnego uczestnictwa w społeczeństwie obywatelskim, a wolontariusze to osoby, które podejmując decyzję o pracy charytatywnej, robią to w sposób świadomy i odpowiedzialny. Wolontariat jest dobrowolny, a to jest bardzo ważna cecha, ponieważ w działaniach uczestniczą tylko zainteresowani uczniowie, wręcz zdeterminowani do pomocy. Taka sytuacja przyspiesza procesy edukacyjne i kształceniowe.

Działalność szkolnego wolontariatu stała się w ostatnich latach nie tylko bezinteresownym okazywaniem pomocy. Niestety, mechanizm zachęcania uczniów czy szkół do udziału w charytatywnych akcjach, opierający się na rywalizacji i nagrodach, wypaczył tę szlachetną ideę. Można sobie zadać pytanie: Czy rywalizacja uczniowskich działań w ramach wolontariatu nie przynosi oczekiwanego sukcesu w postaci coraz to większej liczby akcji, zwiększenia ich zasięgu i efektów?

\section{Szkolny wolontariat - dobre praktyki}

Szkoła podstawowa jest, wbrew pozorom, trudnym miejscem do działania wolontariatu, a wynika to $z$ tego, że osoby małoletnie nie mogą uczestniczyć we wszystkich typach działań na rzecz innych. Ze względu na wiek uczniowie muszą być pod bezpośrednią opieką nauczycieli 
lub rodziców. Pomimo tego bardzo ważnego ograniczenia aktualnie szkoły podstawowe stały się miejscem intensywnych działań małych wolontariuszy. $Z$ reguły placówki oświatowe nie inicjują akcji charytatywnych, ale w dużej mierze uczestniczą w akcjach o zasięgu krajowym, regionalnym i lokalnym. Oczywiście zdarzają się sytuacje, w których jest organizowana pomoc wręcz indywidualna, bardzo często dotycząca pojedynczego ucznia czy jego rodziny, ale w tym opracowaniu pod uwagę zostały wzięte duże akcje charytatywne, w które angażuje się duża liczba placówek oświatowych.

W tej części opracowania zostaną przedstawione wybrane działania społeczne realizowane w szkołach podstawowych. W większości są to działania polegające na realizacji oryginalnych projektów wolontariackich w szkołach podstawowych przez wolontariuszy rekrutujących się spośród uczniów danej szkoły. Udział w tych projektach wymaga od uczniów uruchomienia swoich kompetencji z zakresu szeroko rozumianej przedsiębiorczości i innowacyjności. Ta sytuacja wynika z olbrzymiej liczby akcji charytatywnych organizowanych przez różne instytucje i dla różnych grup docelowych. Długoletnie obserwacje działalności szkolnego wolontariatu w różnych szkołach podstawowych na terenie Krakowa mogą doprowadzić do wniosku, że następuje "zmęczenie" kolejną akcją charytatywną. Jest to pozorne stwierdzenie, ponieważ kolejne akcje pomocowe zmuszają uczniów do kreatywności i innowacyjności w zakresie zdobywania środków pomocowych. Szkoły, uczestnicząc w akcjach charytatywnych organizowanych przez Caritas Polska czy Wielką Orkiestrę Świątecznej Pomocy, organizują szkolne wydarzenia, na które składają się aukcje prac plastycznych, aukcje rzeczowe i wiele wydarzeń o charakterze kulturalnym, naukowym, sportowym, które pozwolą zebrać środki na szczytny cel.

Najczęściej w szkołach organizowane są wszelkiego rodzaju zbiórki, np. finansowe - "Góra grosza” (w 2017 r. uczestniczyło w niej 9 tys. szkół) czy Wielka Orkiestra Świątecznej Pomocy. WOŚP jest corocznym wydarzeniem, do którego szkoły przygotowują się kilka tygodni wcześniej. W 2019 r. Jerzy Owsiak zorganizował już 27. finał tego wydarzenia, w którym uczestniczyło ponad 1,5 tys. sztabów, z czego około 20 proc. to sztaby zorganizowane w szkołach podstawowych, a nawet w przedszkolach. Oprócz kwest finansowych organizowane są liczne zbiórki produktów żywnościowych, są to takie akcje jak: „Szlachetna paczka" (wartość udzielonej pomocy to około $25 \mathrm{mln}$, liczba zaanga- 
żowanych osób w pomoc to 440 tys.), „Pomóż dzieciom przetrwać zimę" (300 sztabów w Polsce) czy "Tak pomagam" organizowane przez Caritas Polska (Towarzystwo Nasz Dom 2018, Wielka Orkiestra Świątecznej Pomocy 2018, Szlachetna Paczka 2018, Ogólnopolska Akcja Charytatywna 2018, Caritas, Tak pomagam 2018).

Beneficjentami tej pomocy są różne grupy docelowe, ale w szkołach podstawowych bardzo dużym zainteresowaniem cieszy się pomoc zwierzętom. Na przykład "Gwiazdka dla zwierzaka" polega na zbiórce darów dla zwierząt mieszkających w schronisku. Placówki uczestniczące w akcji otrzymują dyplomy, natomiast te, które zbiorą najwięcej darów - certyfikaty okolicznościowe. W roku szkolnym 2017/2018 w akcji uczestniczyły 242 placówki, którym udało się zebrać 20 ton karmy dla zwierząt.

Jak wielka jest rola wolontariatu, świadczy chociażby ustanowienie 5 grudnia Międzynarodowym Dniem Wolontariusza. Innym sposobem uhonorowania najmłodszych wolontariuszy są doroczne podsumowania działalności i wybór wolontariusza/wolontariuszy roku. Jest to organizowane przez szkoły, kuratoria oświaty i organizacje działające charytatywnie.

\section{Podsumowanie}

Bardzo ważnym zagadnieniem jest kontekst kształcenia i uczenia jako twórczej adaptacji do świata. Oznacza to odpowiedzialne, krytyczne i racjonalne przystosowanie się do zmieniających się uwarunkowań rozwoju współczesnego świata. Działalność w szkolnym wolontariacie pozwoli na bardzo wstępne określenie roli i pozycji młodego człowieka w społeczeństwie. Przewrotnie można powiedzieć, że młody człowiek ma możliwość zaobserwowania sytuacji, w której "można dawać", ale i "można brać". Różne aspekty związane z ekonomią społeczną - w tym wolontariat, działalność w organizacjach pozarządowych i podmiotach społecznych - z pewnością są ważnym elementem kształtowania kompetencji kluczowych i umiejętności uniwersalnych niezbędnych do funkcjonowania na rynku pracy.

Działania uczniów w szkolnym wolontariacie są bardzo dobrym przykładem edukacji przez przedsiębiorczość, gdzie nauczanie charakteryzuje się podejściem skoncentrowanym na wyzwaniach, rozwiązywaniu problemów w innowacyjny, kreatywny sposób. Dodatkowymi argumentami za wolontariatem są praktyczne działanie oraz społeczna 
użyteczność tego zjawiska. Umiejętności o charakterze ogólnym, takie jak zdolność krytycznego myślenia, podejmowanie inicjatyw, rozwiązywanie problemów i praca w grupie, przygotowują młodego człowieka na zróżnicowane i nieprzewidywalne ścieżki kariery we współczesnych czasach. Wolontariat może być przykładem aktywnej metody nauczania "o" przedsiębiorczości, „dla” przedsiębiorczości i „przez” przedsiębiorczość, realizowanych w formie projektu uczniowskiego.

Działalność w wolontariacie może spowodować, że młody człowiek będzie bardziej świadomy własnych kompetencji, talentów oraz swoich mocnych i słabych stron. To pozwoli w przyszłości kształtować swoją ścieżkę edukacyjno-zawodową poprzez poznanie samego siebie, a także poznanie możliwości stwarzanych przez współczesne procesy rozwojowe. Współcześnie wolontariat to nie tylko "zbieranie funduszy do puszki", lecz także zdobywanie doświadczenia i kompetencji, które w przyszłości będą stanowiły o potencjale młodego człowieka świadomie zarządzającego swoimi własnymi zdolnościami i talentami. Wolontariat to przede wszystkim kształtowanie aktywnej postawy społecznej i obywatelskiej. 


\section{Bibliografia}

$\rightarrow$ Atroszko, B. (2015), Rozwój kompetencji inicjatywności i przedsiębiorczości w ramach nauki szkolnej w Polsce. Reviewed Proceedings of the Interdisciplinary Scientific International Conference for PhD students and assistants QUAERE 2015, vol. V May 25-29, 2015, Hradec Králové (Ceska Republika): Magnanimitas, s. 1319-1325.

$\rightarrow$ Bieńkowska, B. (2017), Przedsiębiorczość i innowacyjność - próba refleksji nad ich miejscem w systemie oświaty, [w:] „Research Papers of the Wroclaw University of Economics/Prace Naukowe Uniwersytetu Ekonomicznego we Wrocławiu" (489), s. 44-56.

$\rightarrow$ Borowiec, M., Rachwał, T. (2011), Kształtowanie postaw przedsiębiorczych na lekcjach geografii wyzwaniem edukacyjnym w procesach globalizacji, [w:] "Przedsiębiorczość - Edukacja”, nr 7, s. 321-332.

$\rightarrow$ Borowiec-Gabryś, M., Kilar, W., Rachwał T. (2018), Przedsiębiorczość jako kompetencja przyszłości, [w:] S. Kwiatkowski (red.), Kompetencje przyszłości, Seria Naukowa, t. 3, Warszawa: Fundacja Rozwoju Systemu Edukacji, s. 68-89.

$\rightarrow$ Górniak, J. (2013), Młodość czy doświadczenie. Kapitał ludzki w Polsce. Raport podsumowujący III edycję badań BKL, 2012, s. 83-84.

$\rightarrow$ Kulig-Moskwa, K. (2013), Wolontariat jako instrument kształtowania kompetencji pożądanych na rynku pracy, "Zeszyty Naukowe Wyższej Szkoły Bankowej we Wrocławiu", nr 4 (36), s. 115-127.

$\rightarrow$ Piróg, D. (2015), Kompetencje z zakresu przedsiębiorczości: rozważania teoretyczne i ich ilustracje w obszarze szkolnictwa wyższego, „Przedsiębiorczość - Edukacja", nr 11, s. 364-376.

$\rightarrow$ Rachwał, T. (2005), Kształtowanie postaw u uczniów na lekcjach podstaw przedsiębiorczości, „Przedsiębiorczość - Edukacja” , nr 1, s. 137-144.

$\rightarrow$ Rachwał, T., Wach, K. (2016), Badanie intencji przedsiębiorczych młodego pokolenia: wyniki ankietyzacji wśród studentów kierunków nieekonomicznych, „Przedsiębiorczość - Edukacja”, nr 12, s. 405-415. 
$\rightarrow$ Rachwał, T., Kilar, W., Kawecki, Z., Wróbel, P. (2018), Edukacja w zakresie przedsiębiorczości w wychowaniu przedszkolnym, szkole podstawowej i szkołach średnich w świetle nowej podstawy programowej, „Przedsiębiorczość - Edukacja", nr 14, s. 389-424.

$\rightarrow$ Roguska, A. (2010), Wolontariat-działania na rzecz jednostki i społeczeństwa, [w:] M. Danielak-Chomać, B. Dobrowolska, A. Roguska (red.), Wolontariat w teorii i praktyce, Siedlce, s. 27-48.

$\rightarrow$ Strojny, J. (2007), Kształtowanie postawy przedsiębiorczej-procesy socjalizacji i autokreacji. Kształtowanie postaw przedsiębiorczych a edukacja ekonomiczna, Warszawa: Fundacja Promocji i Akredytacji Kierunków Ekonomicznych, s. 205-211.

$\rightarrow$ Wach, K. (2013), Edukacja na rzecz przedsiębiorczości wobec współczesnych wyzwań cywilizacyjno-gospodarczych, „Przedsiębiorczość - Edukacja”, nr 9, s. 246-257.

$\rightarrow$ Załuska, M. (1996), Społeczne uwarunkowania angażowania się w działalność organizacji pozarządowych, [w:] M. Załuska, J. Boczoń (red.), Organizacje pozarzq̨dowe w społeczeństwie obywatelskim, Warszawa: Interart. 


\section{Netografia}

$\rightarrow$ Towarzystwo Nasz Dom, Góra Grosza, towarzystwonaszdom.pl/app/ uploads/2017/11/Rozliczenie-Akcji-G\%C3\%B3ra-Grosza-18-edycja.pdf [dostęp 8.12.2018].

$\rightarrow$ Wielka Orkiestra Świątecznej Pomocy, www.wosp.org.pl/final/sztaby [dostęp 8.12.2018].

$\rightarrow$ Szlachetna Paczka, www.szlachetnapaczka.pl/wyniki [dostęp 13.12.2018].

$\rightarrow$ Ogólnopolska Akcja Charytatywna, Pomóż dzieciom przetrwać zimę, www.pdpz.pl [dostęp 8.12.2018].

$\rightarrow$ Caritas, Tak pomagam, caritas.pl/projekty/tak-pomagam [dostęp 8.12.2018]. 


\section{Formy i metody kształcenia w zakresie przedsiębiorczości \\ w szkole podstawowej}

Anna Śliwińska

W artykule podjęto problematykę kształtowania postaw przedsiębiorczych w szkole podstawowej w kontekście obowiązującej podstawy programowej. Zwrócono szczególną uwagę na kształtowanie kluczowych kompetencji i konieczność stwarzania sytuacji dydaktycznych, które temu sprzyjają. Wykazano zależność między formułowaniem celów a ocenianiem postępów uczniów. Na tym tle określono miejsce przedsiębiorczości we współczesnej szkole.

\section{_ Słowa kluczowe: \\ przedsiębiorczość \\ kreatywność \\ innowacyjność \\ podstawa programowa \\ kluczowe umiejętności}




\section{Forms and methods of education in the field of developing \\ entrepreneurial competences}

Anna Śliwińska

The article discusses the problem of shaping entrepreneurial attitudes in primary school in the context of the current core curriculum. Particular attention is paid to shaping key competences and the necessity to create teaching situations that support them. The relationship between formulating goals and assessing students' progress was demonstrated clearly in the article. Against this background, the place of entrepreneurship in a modern school was defined.

- Keywords:

entrepreneurship

creativity

innovation

core curriculum

key skills 


\section{Wstęp}

W 2012 r. powstał raport ${ }^{1}$ dotyczący rozwijania kompetencji kluczowych w szkołach Europy. Wynika z niego, że wszystkie europejskie kraje zwiększyły rolę tych kompetencji w programach nauczania, ale nie w równomierny sposób. Okazało się, że główny nacisk został położony na rozwijanie umiejętności czytania i pisania, posługiwania się językiem obcym oraz na matematykę i nauki ścisłe. Niestety, umiejętności, które wydają się niezwykle istotne z punktu widzenia współczesnego pracodawcy, czyli kompetencje cyfrowe, społeczne, a także przedsiębiorczość, znalazły się na drugim planie. Podstawa programowa ${ }^{2}$ wprowadzona w 2017 r. kładzie jednak duży nacisk na kształcenie tych kompetencji.

\section{Cele kształcenia}

Zadaniem szkoły na każdym etapie kształcenia jest przygotowanie uczniów do dorosłego życia - do planowania i realizacji zamierzeń, do tego, by potrafili zamieniać zamiary w czyny, by umieli powiedzieć "mogę", „potrafię". Kluczowe na początku pracy z uczniami wydaje się uświadomienie im celów, ponieważ to motywuje do uczenia się i daje poczucie sensownie spędzonego czasu w szkole. Poprawne sformułowanie celów nauczania pomaga również nauczycielowi w przygotowaniu spójnej lekcji, w nastawieniu się na konkretne działania. Twórcy i propagatorzy oceniania kształtującego sugerują wręcz, by nie tylko uzgodnić z uczniami cele lekcji (oczywiście w dostosowanym do nich języku, czyli w języku ucznia), lecz także zapisać je w widocznym miejscu lub wkleić do zeszytu. W edukacji wczesnoszkolnej często pojawiają się w klasach wypisane cele, które przyświecają realizacji programu w danym miesiącu/tygodniu/dniu. Twórcy oceniania kształtującego (zob. Moss, Brookhart 2014) podkreślają, że właściwie sformułowane

1. Komisja Europejska/EACEA/Eurydice (2012), Developing Key Competences at School in Europe: Challenges and Opportunities for Policy (Rozwijanie kompetencji kluczowych w szkołach w Europie. Wyzwania i możliwości tworzenia polityki edukacyjnej) Raport Eurydice, Luksemburg: Urząd Publikacji Unii Europejskiej.

2. Rozporządzenie Ministra Edukacji Narodowej z dnia 14 lutego 2017 r. w sprawie podstawy programowej wychowania przedszkolnego oraz podstawy programowej kształcenia ogólnego dla szkoły podstawowej, w tym dla uczniów z niepełnosprawnością intelektualną w stopniu umiarkowanym lub znacznym, kształcenia ogólnego dla branżowej szkoły I stopnia, kształcenia ogólnego dla szkoły specjalnej przysposabiającej do pracy oraz kształcenia ogólnego dla szkoły policealnej. 
cele przekładają się na jasne kryteria oceny, czyli dowody, iż cel został osiągnięty (Sterna 2015).

Celem szkoły powinno być kształtowanie umiejętności i postaw kreatywnych, przedsiębiorczych i innowacyjnych, a w szczególności:

$\rightarrow$ pracy zespołowej,

$\rightarrow$ generowania pomysłów,

$\rightarrow$ rozpoznawania i rozwiązywania konfliktów,

$\rightarrow$ wykorzystywania technologii informacyjno-komputerowych,

$\rightarrow$ gromadzenia i selekcji materiału,

$\rightarrow$ prezentacji,

$\rightarrow$ planowania i realizowania przedsięwzięć uczniowskich.

Cele te spójne są z celami kształcenia ogólnego, umiejętnościami, które szkoła ma rozwijać, oraz zalecanymi warunkami i sposobami realizacji wymagań zawartymi w podstawie programowej.

\section{Tabela 1. Kształtowanie umiejętności i postaw przedsiębiorczych}

\begin{tabular}{|c|c|}
\hline KLUCZOWE ZAGADNIENIA & KSZTAŁTOWANE UMIEJĘTNOŚCI UCZNIÓW \\
\hline współpraca w grupie & $\begin{array}{l}\rightarrow \text { określają swoje miejsce w grupie } \\
\rightarrow \text { rozpoznają role w grupie i związane z nimi oczekiwania } \\
\rightarrow \text { nazywają i rozpoznają cechy lidera } \\
\rightarrow \text { omawiają zadania lidera } \\
\rightarrow \text { wskazują trudności związane z pełnieniem funkcji lidera } \\
\rightarrow \text { nazywają zachowania, które ułatwiają porozumiewanie się } \\
\text { i utrudniają współpracę } \\
\rightarrow \text { wymieniają korzyści wynikające ze współpracy }\end{array}$ \\
\hline generowanie pomysłów & $\begin{array}{l}\rightarrow \text { szukają różnorodnych rozwiązań problemu } \\
\rightarrow \text { oceniają pomysły własne i innych oraz na ich temat dyskutują } \\
\rightarrow \text { wskazują problemy związane z poszukiwaniem pomysłów } \\
\rightarrow \text { szukają argumentów, by poprzeć swoje stanowisko } \\
\rightarrow \text { stosują zasady współpracy w grupie }\end{array}$ \\
\hline $\begin{array}{l}\text { rozpoznawanie } \\
\text { i rozwiązywanie konfliktów }\end{array}$ & $\begin{array}{l}\rightarrow \text { rozważają różne możliwości rozwiązania problemu } \\
\rightarrow \text { gromadzą argumenty na poparcie własnego stanowiska } \\
\rightarrow \text { negocjują warunki } \\
\rightarrow \text { prezentują własne stanowisko w sprawie } \\
\rightarrow \text { wyjaśniają na konkretnych przykładach zasady współżycia mię- } \\
\text { dzy ludźmi, ze szczególnym zwróceniem uwagi na odpowiedzialnośc } \\
\text { i zaufanie } \\
\rightarrow \text { wspólnie rozwiązują problem }\end{array}$ \\
\hline $\begin{array}{l}\text { wykorzystanie technologii } \\
\text { informacyjno-komputerowej }\end{array}$ & $\begin{array}{l}\rightarrow \text { poszukują informacji, wykorzystując technologię informacyjną } \\
\rightarrow \text { tworzą dokumenty, wykorzystując technologię informacyjną }\end{array}$ \\
\hline
\end{tabular}




\begin{tabular}{l|l}
\multicolumn{1}{c|}{ KLUCZOWE ZAGADNIENIA } & \multicolumn{1}{c}{ KSZTAŁTowANE UMIEJĘTNOścı UCZNIów } \\
\hline gromadzenie i selekcja & $\rightarrow$ wykorzystują zdobyte informacje przy podejmowaniu decyzji \\
materiału & $\rightarrow$ weryfikują i wykorzystują wiedzę z różnych dziedzin nauki, by zna- \\
& leźć rozwiązanie \\
& $\rightarrow$ układają zdobyte informacje zgodnie z hierarchią ważności \\
& $\rightarrow$ oceniają zgromadzone materiały pod kątem zgodności z tematem \\
\hline prezentacja & $\rightarrow$ prezentują własne dokonania \\
planowanie i realizowanie & $\rightarrow$ wymieniają elementy ułatwiające i utrudniające odbiór prezentacji \\
przedsięwzięć uczniowskich & $\rightarrow$ oceniają prezentację \\
& $\rightarrow$ przygotowują materiały wizualizujące \\
& $\rightarrow$ formułują zasady dobrej prezentacji \\
\hline planują działania \\
& $\rightarrow$ docierają do odbiorców (prowadzą działania marketingowe) \\
& $\rightarrow$ formułują zasady dobrej organizacji pracy \\
& $\rightarrow$ monitorują na bieżąco działania \\
& $\rightarrow$ wyjaśniają, dlaczego trzeba na bieżąco monitorować działania \\
& $\rightarrow$ uzasadniają potrzebę korygowania planu \\
& $\rightarrow$ planują alternatywne rozwiązania \\
& $\rightarrow$ uzasadniają potrzebę dokumentowania działań \\
& $\rightarrow$ analizują własne działania i działania innych osób/grup \\
& $\rightarrow$ wyciągają wnioski \\
& $\rightarrow$ formawiają mocne i słabe strony przedsięwzięć \\
&
\end{tabular}

Źródło: Opracowanie własne.

Zajęcia lekcyjne powinny być tak skonstruowane, by wyposażyć uczniów w umiejętność powiązania różnych dziedzin wiedzy i jej wykorzystania. Taka organizacja procesu nauczania ma pomóc uczniom zrozumieć otaczający świat i prawa nim rządzące. Dlatego należy wyjść od zmiany koncepcji roli nauczyciela. Musi on stać się organizatorem, strategiem i negocjatorem, motywować uczniów i inicjować ich działania. Uczniowie natomiast powinni w wyraźny sposób wpływać na proces uczenia się i stawać się odpowiedzialni za własny rozwój. Istotne jest, by młody człowiek uczył się rozwiązywać autentyczne problemy, które mogą go zainteresować.

Postawione cele mogą zostać osiągnięte dzięki zastosowaniu różnorodnych aktywnych metod uczenia się i nauczania.

\section{Metody i formy ksztalcenia}

Uczniowie powinni pracować metodami aktywnymi, nauczyciel zaś, wprowadzając treści programowe, powinien uczyć jednocześnie umiejętności pracy zespołowej, rozwiązywania konfliktów, planowania pracy, 
odpowiedzialności, rozwijania kreatywnych umiejętności, gromadzenia informacji, ich selekcji; powinien integrować zespół, pozwalać uczniom na własną ekspresję, uczyć zasad prezentacji, samooceny, wyciągania wniosków, a nawet planowania wydatków. $Z$ działaniami tymi nie można czekać, aż uczeń będzie dojrzały, należy kształtować je od najmłodszych lat. Warto też pamiętać, by zaczynać od działań na niewielką skalę, aby uczeń wdrożył się do pracy, poznał swoje możliwości, nauczył się polegać na kolegach i udowodnił, że inni mogą polegać na nim, a także by mógł doświadczać sukcesów i porażek. Tak dobrane metody wydają się najlepszym narzędziem do realizacji spiralnego układu treści kształcenia i celów wychowawczych sformułowanych w programach nauczania.

Zalecane są metody problemowe, służące zrozumieniu i działaniu, np. dyskusje i debaty, odgrywanie ról, scenek, drama, drzewko decyzyjne, gwiazda pytań, gra dydaktyczna, giełda pomysłów, burza mózgów, metoda przypadków, praca z interaktywnymi multimediami, słoneczko, poker kryterialny, metoda projektów.

Nauczyciel, realizując zajęcia, powinien sięgać głównie po formy pracy zbiorowej, by rozwijać umiejętności pracy w grupie, komunikacji i wzajemnego wspierania się w rozwiązywaniu problemów. Indywidualizacja pracy może być stosowana poprzez samodzielne tworzenie tekstów i realizację ćwiczeń interaktywnych, ale przede wszystkim poprzez udział ucznia w projektach, a tym samym realizację przyjętych na siebie zadań i gromadzenie informacji potwierdzających własny rozwój - portfolio.

W pierwszym etapie edukacji proces kształcenia powinien być ukierunkowany na całościowy rozwój dziecka, rozpoznawanie jego możliwości, wspieranie mocnych stron i korygowanie słabszych. Zajęcia powinny być tak skonstruowane, by motywować do poznawania siebie i otoczenia, by gromadzić doświadczenia, eksperymentować. To okres, gdy dzieci są bardzo ciekawe, chcą poznawać świat, są otwarte i pozytywnie nastawione do wszelkich nowości. Ta naturalna ciekawość otaczającego świata wpływa na motywację do uczenia się.

\section{Propozycje rozwiązań praktycznych}

Kształtowanie kompetencji przedsiębiorczych można realizować w trakcie zajęć wychowawczych. Już od pierwszego etapu kształcenia nauczyciel-wychowawca organizuje różnorodne uroczystości. Powtarzającym 
się świętem w części szkół są wigilie. W klasach I-III bardzo często w organizację włączają się rodzice. To bardzo ważne z punktu widzenia dziecka - daje mu poczucie bezpieczeństwa, a także możliwość pochwalenia się swoimi umiejętnościami i osiągnięciami. Ważne, by wychowawca nie oddał całej inicjatywy w ręce rodziców, ale znalazł zadanie, za które odpowiedzialne będą dzieci, np. dekoracja sali. Na pewno choinka ubrana przez rodziców będzie bardziej elegancka, ale wykonanie ozdób świątecznych i zawieszenie ich na choince oraz w sali to na pewno zadanie, które mogą wykonać same dzieci (oczywiście na lekcjach, pod kierunkiem nauczyciela). Dzięki takim zadaniom uczą się odpowiedzialności i współpracy, stają się współodpowiedzialne za uroczystość. Zazwyczaj nauczyciel przygotowuje z dziećmi przedstawienie, by mogły wystąpić przed rodzicami. Tutaj też można część inicjatywy oddać w ręce dzieci. Mogą wybrać teksty i osoby występujące, przygotować dekoracje. W klasach starszych, na drugim etapie edukacji, trzeba ograniczać ingerencję rodziców w organizację uroczystości klasowych i coraz większą inicjatywę przekazywać samym uczniom. Organizacja wspólnych przedsięwzięć klasowych może być najlepszym sposobem na rozwój kluczowych kompetencji. W trakcie realizacji należy przecież podzielić obowiązki, wybrać osobę, która będzie odpowiedzialna za całokształt (lidera), zebrać (a później rozliczyć) fundusze i przede wszystkim wywiązać się z podjętych zobowiązań. Pojawią się więc tutaj zarówno planowanie, poszukiwanie pomysłów, argumentowanie, monitorowanie przedsięwzięcia, jak i gospodarowanie czasem oraz funduszami. W starszych klasach w ramach działań wychowawczych można w ręce uczniów oddać inicjatywę związaną z przygotowaniem wycieczki. Organizacja takiego przedsięwzięcia to już kompletne zadanie, wymagające wykorzystania wielorakich umiejętności i pełnej współpracy grupy.

Ważnym elementem kształtowania umiejętności przedsiębiorczych są projekty. Uczniowie mogą je realizować już w klasach I-III. Początkowo mają one charakter ogólnoklasowy i są całkowicie realizowane w szkole. Uczniowie uczą się, bawią i przygotowują prezentacje, na które zapraszają inne klasy. Ciekawym projektem, realizowanym w jednej ze szkół, były „Kontynenty". W ramach tego zadania uczniowie klas III tworzyli prezentacje dotyczące wylosowanego kontynentu - przygotowywali dekoracje, stroje, wybierali informacje, które później przekazywali kolegom, zapraszając ich do wspólnej zabawy. Realizując ten projekt, nie tylko zdobyli wiedzę przedmiotową, lecz także kształtowali 
umiejętności. Warto również korzystać z gotowych inspiracji, programów dostosowanych do konkretnych etapów edukacji, np. program realizowany przez Fundację Młodzieżowej Przedsiębiorczości „Od grosika do złotówki" wprowadzający do klas II-III edukację finansową.

W starszych klasach projekt jako metoda pracy powinien pojawiać się na konkretnych przedmiotach. Jednak trzeba uważać, by nie było ich zbyt wiele i by nie przerzucić całej odpowiedzialności na rodziców. Dlatego niezbędne są tutaj współpraca wszystkich nauczycieli uczących daną klasę i wspólne uzgadnianie większych działań edukacyjnych. Należy pamiętać o tym, że mimo rejonizacji szkół podstawowych dzieci nie zawsze mają możliwość spotkania się w swoim gronie po lekcjach i wspólnego realizowania zadania. Takie spotkania często uniemożliwia też nadmiar zajęć pozalekcyjnych. W efekcie może dojść do sytuacji, w której rodzice tylko jednego dziecka zrealizują zadanie, a grupa odda je jako wspólny efekt. I tutaj mamy już antyedukację. Kolejny problem polega na częstej rezygnacji nauczycieli z prezentacji osiągnięć, ponieważ skupiają się jedynie na ocenianiu efektu. Tym samym rezygnują z kształcenia wielu niezbędnych umiejętności i właściwie wypaczają założenia metody projektów. Właśnie ten końcowy efekt wymaga największej pracy i pozwala zdobyć najwięcej umiejętności, budzi też ogromne emocje. Uczniowie muszą stanąć przed grupą i pokazać, czego się nauczyli. Jednak nie zawsze musi to być wystąpienie - zamiast niego można zorganizować np. stoiska, przy których zainteresowani dowiedzą się, co uczniowie zrobili, i dzięki temu sami też wiele się nauczą.

\section{Ocenianie}

Ocenianie w szkole podstawowej powinno łączyć elementy merytoryczne z motywacją, ze szczególnym naciskiem na motywację na pierwszym etapie edukacji. Dlatego warto wprowadzić ocenianie kształtujące, które umożliwia przekazanie uczniowi i jego rodzicom informacji o sposobach oraz efektach pracy, postępach i trudnościach (Sterna 2015). Tym samym ocena ułatwi uczniowi zrozumienie celów zajęć i oczekiwanych osiągnięć, a także przyczyni się do przejęcia odpowiedzialności za własną naukę.

W procesie oceniania powinni uczestniczyć uczniowie, dokonując samooceny i oceny pracy grupy, oraz nauczyciel. Ocenie podlega praca ucznia, czyli sam proces uczenia się, a nie tylko jego efekt końcowy. Doceniane będą postępy oraz wysiłki uczniów, szczególnie w zakresie współ- 
pracy i wzajemnej pomocy. W trakcie wykonywania zadań uczniowie mają możliwość zastanowienia się nad własnymi motywacją i sposobem uczenia się. Informacje wynikające z obserwacji, przekazywane na bieżąco, pomogą w budowaniu poczucia własnej wartości. Informacja zwrotna przekazywana uczniowi i jego rodzicom powinna zawierać:

$\rightarrow$ wyszczególnienie i docenienie tych elementów pracy ucznia, które są wykonywane prawidłowo,

$\rightarrow$ zauważenie tego, co wymaga poprawy,

$\rightarrow$ udzielenie wskazówek, jak poprawić pracę,

$\rightarrow$ wskazanie uczniowi kolejnych celów.

Ocenianie pracy ucznia podczas realizacji innowacji jest skorelowane z obowiązującymi w szkole zapisami dotyczącymi oceniania.

Podczas pracy nauczyciel, obserwując działania swoich podopiecznych, gromadzi i analizuje informacje niezbędne do stymulowania aktywności poszczególnych uczniów, a także planowania i organizowania ich działań. Obserwację tę prowadzi, uwzględniając:

$\rightarrow$ samodzielność, umiejętność wyznaczenia celu i określenia zagadnień istotnych dla rozważanego problemu,

$\rightarrow$ sposób współpracy w zespole,

$\rightarrow$ terminowość i odpowiedzialność w wywiązywaniu się z zaplanowanych prac,

$\rightarrow$ umiejętność rozwiązywania pojawiających się problemów,

$\rightarrow$ pracowitość i inicjatywę,

$\rightarrow$ wykorzystanie różnorodnych źródeł informacji,

$\rightarrow$ umiejętność doboru i selekcji informacji,

$\rightarrow$ umiejętność dokonania samooceny adekwatnej do wkładu i efektów pracy.

\section{Wnioski i rekomendacje}

Wyniki w nauce poszczególnych uczniów zależą od nich samych, ale najlepsze efekty osiąga się wówczas, kiedy nauczyciele podchodzą do nauczania z punktu widzenia uczniów. Szkoła to instytucja, która musi iść z duchem czasu, zmieniać się, nie tylko uczyć, lecz także uczyć się. Należy zmienić podejście do edukacji, odejść od encyklopedyzmu, skoncentrować się na działaniu. Głównym zadaniem szkoły, na każdym etapie edukacji, musi być rozwijanie umiejętności. Dlatego należy sięgać po nowoczesne metody, gdyż obecne pokolenie znacznie różni się od 
młodych ludzi z poprzedniej generacji. Dorastali w świecie nowoczesnych technologii, mają więc bardzo wysoką zdolność funkcjonowania w wirtualnym świecie. Realne życie i kontakty interpersonalne zastępują kontaktami w wirtualnym świecie. Przyszły rynek pracy kształtuje się już w szkole, więc od sposobu kształcenia młodych ludzi zależy ich późniejsza sytuacja w życiu zawodowym. 


\section{Bibliografia}

$\rightarrow$ Sterna, D. (red.) (2015), Oceniam, uczq̨c. Poradnik dla nauczycieli edukacji wczesnoszkolnej, Warszawa: Centrum Edukacji Obywatelskiej.

$\rightarrow$ Moss, C.M., Brookhart, C.M. (2014), Cele uczenia się. Jak pomóc uczniom zrozumieć każdq lekcję, tłum. Weronika Gasperczyk, Warszawa: Centrum Edukacji Obywatelskiej.

$\rightarrow$ Marciniak-Kulka, E., Neyman, O., Wysocka, J. (2017), Wspomaganie szkół w kształtowaniu kompetencji: innowacyjność, kreatywność i praca zespołowa uczniów, Warszawa: Ośrodek Rozwoju Edukacji.

$\rightarrow$ Rozporządzenie Ministra Edukacji Narodowej z dnia 14 lutego 2017 r. w sprawie podstawy programowej wychowania przedszkolnego oraz podstawy programowej kształcenia ogólnego dla szkoły podstawowej, w tym dla uczniów z niepełnosprawnością intelektualną w stopniu umiarkowanym lub znacznym, kształcenia ogólnego dla branżowej szkoły I stopnia, kształcenia ogólnego dla szkoły specjalnej przysposabiającej do pracy oraz kształcenia ogólnego dla szkoły policealnej.

$\rightarrow$ Kompetencje kluczowe w uczeniu się przez całe życie. Europejskie ramy odniesienia (2007), Luksemburg: Urząd Oficjalnych Publikacji Wspólnot Europejskich.

$\rightarrow$ Komisja Europejska/EACEA/Eurydice (2012), Developing Key Competences at School in Europe: Challenges and Opportunities for Policy (Rozwijanie kompetencji kluczowych w szkołach w Europie. Wyzwania i możliwości tworzenia polityki edukacyjnej) Raport Eurydice, Luksemburg: Urząd Publikacji Unii Europejskiej. 


\title{
Pozycja i ranga przedsiębiorczości w edukacji geograficznej \\ w szkole podstawowej w kontekście zmian edukacyjnych
}

\author{
Monika Borgiasz-Stepaniuk
}

Edukacja, a szczególnie nauczanie elementów przedsiębiorczości, tworzy możliwości rozwoju dla młodego człowieka, który musi funkcjonować we współczesnym świecie. Kształcenie młodzieży w sferze przedsiębiorczości to determinanta wzrostu gospodarczego kraju. W dobie konkurencyjności rozwijanie u młodych ludzi umiejętności i zdolności innowacyjnych wpływa na przygotowanie ich do dorosłego życia, w dynamicznie zmieniającej się rzeczywistości. Oznacza to wprowadzenie do nauczania treści przedsiębiorczych od najwcześniejszych lat szkolnych. Problemem badawczym niniejszej pracy jest analiza podstawy programowej z geografii zreformowanej szkoły podstawowej pod kątem przedsiębiorczości. Autorka koncentruje swoją uwagę na treściach z zakresu przedsiębiorczości, które mogą być realizowane na różnych poziomach nauczania geografii w szkole podstawowej. W niniejszym opracowaniu przeanalizowano treści geograficzne pod kątem przedsiębiorczości, wskazano umiejętności, które uczeń powinien osiągnąć w trakcie ich realizowania, oraz podano przykłady prezentacji tematyki przedsiębiorczości na lekcjach. Aktywność, otwartość, liberalizm, ciekawość świata oraz pokonywanie ograniczeń to tylko niektóre z elementów pojawiających się w edukacji z przedsiębiorczości w zreformowanej szkole podstawowej.

\section{__ Słowa kluczowe:}




\section{Position and rank of entrepreneurship in geographic education in primary school in the context of educational changes}

Monika Borgiasz-Stepaniuk

Education, and especially the teaching of entrepreneurial elements, creates opportunities for development for a young man who must function in the modern world. Educating young people in the sphere of entrepreneurship is the determinant of the country's economic growth. In the era of competitiveness, developing young people's skills and innovative abilities influences their preparation for adult life, in a dynamically changing reality. This means introducing entrepreneurial content into teaching from the earliest school years. The research problem of this study is the analysis of the core curriculum in the geography of the reformed primary school in terms of entrepreneurship. The author focuses her attention on entrepreneurial content that can be implemented at various levels of geography teaching in a primary school. This study analyzes geographic content in terms of entrepreneurship, indicates the skills that a student should achieve during their implementation and gives examples of presentation of the subject of entrepreneurship in the classroom. Activity, openness, liberalism, curiosity of the world and overcoming limitations are just some of the elements emerging in education from entrepreneurship in a reformed primary school.

\section{Keywords:}




\section{Wstęp}

Przedsiębiorczość jest interpretowana jako zachowania, które wyrażają się w predyspozycjach człowieka. Są to między innymi: umiejętność dostosowania się do zmieniających się warunków otoczenia, wykonywania określonych działań i dopasowywanie ich do odpowiednich celów. Warunkowana jest licznymi czynnikami, które mają wpływ na jej rozwój. Rzeczywiste zachowania przedsiębiorcze są odmienne i zależne od zakresu analizy oraz odpowiedniego rozróżnienia.

Dyskusja na temat przedsiębiorczości pokazuje, że jest ona określana z jednej strony naturalnymi umiejętnościami, a z drugiej - pozytywnymi i pożądanymi czynnikami przestrzennymi, które tę przedsiębiorczość tworzą, aktywizują, ale także spowalniają.

W tym miejscu pojawia się pytanie, czy przedsiębiorczość to wartość wrodzona czy nabyta. Literatura specjalistyczna potwierdza, że człowiek nie rodzi się przedsiębiorczy. Można w tym miejscu powołać się na słowa Alberta Shapero (1982), który twierdzi, że człowiek staje się przedsiębiorczy. Jego zdaniem cechy, które wyróżniają osobę przedsiębiorczą od innych, nie mają związku z dziedzicznością. Zdobywa się je poprzez naukę i doświadczenie oraz osobistą selekcję i postanowienia. W trakcie edukacji i zdobywania doświadczenia ludzie osiągają umiejętności przedsiębiorcze, stanowiące elementy wyuczone. Potrzebna w byciu przedsiębiorczym jest determinacja w edukacji (Shapero 1982).

Można więc przyjąć, że zdobywanie wiedzy oraz kształtowanie określonych umiejętności robi z człowieka osobę przedsiębiorczą. Działania przedsiębiorcze są konsekwencją połączenia rzeczywistości wewnętrznej i zewnętrznej oraz wzajemnego ich krzyżowania się. Następstwami takiego procesu może być rozwój przedsiębiorczości, ale także jej ograniczenie.

Czynnikami zewnętrznymi, które determinują przedsiębiorczość, są edukacja i jej organizacja. Wiedza jako element mający wpływ na ożywienie społeczno-gospodarcze jest kapitałem intelektualnym we współczesnej gospodarce. Tworzenie i wykorzystywanie wiedzy warunkuje postęp technologiczny, a także gospodarczy i społeczny. Poziom edukacji jest czynnikiem mającym wpływ na konkurencyjność regionu i jego poziom rozwoju. Poprawia jakość życia i zwiększa korzyści społeczne (Kabaj 1997; Grodzicki 2000; Zajączkowska-Jakimiak 2002; Wieloński 2003). 
Autorka niniejszej publikacji skupia się na elementach przedsiębiorczych, które pojawiają się w toku edukacji geograficznej w zreformowanej szkole podstawowej. Nauka na tym poziomie jest znacząca ze względu na dużą chęć poznawczą dzieci oraz możliwości sterowania procesem nauczania na tym etapie nauki. Dzięki kształtowaniu postaw przedsiębiorczych od najwcześniejszych lat szkolnych młody człowiek będzie coraz bardziej świadomy zdobywanej wiedzy i umiejętności, co pozwoli mu na podjęcie wyzwań cywilizacyjnych. Kształtowanie postaw przedsiębiorczych od najmłodszych lat przygotowuje dziecko do znalezienia się w zmieniającej się rzeczywistości oraz pomaga aktualizować wiedzę i umiejętności w toku uczenia się (Borowiec, Rachwał 2011). Im wcześniej postawy przedsiębiorcze będą wykształcane, tym szybciej staną się one cechami osobowości danego człowieka.

\section{Kształtowanie postaw przedsiębiorczych}

Przedsiębiorczość jako pojęcie związane z nowymi możliwościami odgrywa dużą rolę w rozwoju świata. Zarówno współczesna gospodarka, jak i społeczeństwo zmieniają się pod wpływem aktywności i wszelkiego rodzaju inicjatyw mających swoje źródło w ludziach przedsiębiorczych. To właśnie oni w sposób bezpośredni biorą udział w zmianach społeczno-gospodarczych i kształtują współczesność. Ich wiedza, umiejętności i zdobywane doświadczenie wpływają na obraz określonego miejsca, a także danego społeczeństwa.

Kształtowane postawy przedsiębiorcze, cechy charakteru i zdolności pociągają za sobą działania decydujące o rozwoju danego regionu. W tym miejscu można sobie zadać pytanie: Czy każdy może być przedsiębiorczy? Wiadomo już, że przedsiębiorczość jest cechą nabytą, a nie wrodzoną. Nie ma w literaturze specjalistycznej określonego wzorca osoby przedsiębiorczej. Niełatwo jest zatem opisać atrybuty, które stanowią o zachowaniach przedsiębiorczych. Mimo wszystko można wyróżnić te cechy, które przeważają i są właściwe dla ludzi przedsiębiorczych. Są to dominanty aktywne, niestandardowe i buntownicze (Safin 2004).

Osoba przedsiębiorcza odznacza się takimi przymiotami, które są różnorodnie oceniane przez określone zbiorowości społeczne. Mogą być klasyfikowane jako cechy wartościowe i pożyteczne, ale także jako elementy ograniczające postęp regionalny. Tworzą pozytywne modele lub negatywne schematy (Kets de Vries 1985). 
W literaturze tematycznej wskazuje się, że wartościowe postawy przedsiębiorcze można rozwinąć i umocnić poprzez edukację. Człowiek rozwijający postawy przedsiębiorcze musi umiejętnie i rzeczowo ocenić własne zdolności oraz możliwości, konsekwentnie wzbogacając swoją wiedzę oraz umiejętności (Otoliński 1996).

Tego rodzaju starania przeprowadza się dzięki edukacji. Dotyczy to zarówno osób młodych, wchodzących na drogę zawodową, jak i tych, które posiadają już doświadczenie specjalistyczne. Łączenie nauki z rozwijaniem postaw przedsiębiorczych tworzy impulsy pobudzające i uaktywniające rozwój wewnętrzny człowieka, ale także całego społeczeństwa. Ważna jest w tym miejscu zgoda społeczna i szacunek dla osób aktywizujących daną przestrzeń. Kształcenie postaw przedsiębiorczych powinno być postępowaniem wieloletnim i wspomagającym osoby przedsiębiorcze na każdym etapie rozwoju osobistego (National Content Standards for Entrepreneurship Education).

Założenia przedsiębiorczości we współczesnych naukach przekraczają granice nauk ekonomicznych i wchodzą w ramy nauk społecznych. Postawy przedsiębiorcze kształtowane są przez takie elementy, które związane są z otaczającą rzeczywistością. Otoczenie daje zasięg dla pojawiania się dominant wpływających na zachowania człowieka, $w$ tym także działania przedsiębiorcze. Na takim gruncie odpowiednio kształtowane cechy osobowościowe, wspierane wiedzą, mają możliwość rozwijania się w stronę przedsiębiorczości (Kurczewska 2010).

Zakładając, że przedsiębiorczość nie jest cechą wrodzoną, autorka publikacji wychodzi z założenia, że człowiek w trakcie całego życia, zdobywając wiedzę i odpowiednie umiejętności, staje się osobą przedsiębiorczą. Dodatkowo jego postawy oraz relacje z innymi ludźmi mają wpływ na nadawanie kształtu zachowaniom przedsiębiorczym. Drugi człowiek może mobilizować i wspomagać aktywności przedsiębiorcze, ułatwiając podejmowanie określonych decyzji. Postępowanie przedsiębiorcze jest zależne zarówno od cech osobowościowych człowieka, jak i od elementów kulturowych, które na niego działają. Charakter i predyspozycje w połączeniu z kwalifikacjami i ze zdolnościami tworzą osobę w pełni przedsiębiorczą.

Można więc sformułować hipotezę, że włączanie treści z zakresu przedsiębiorczości do edukacji geograficznej na poziomie szkoły podstawowej oraz odpowiedzialne i umiejętne realizowanie tej tematyki przez nauczycieli geografii zapewnia odpowiednie przygotowanie 
ucznia do poznania, zrozumienia i reagowania na współczesne wyzwania cywilizacyjne.

\section{Przedsiębiorczość w edukacji geograficznej w zreformowanej szkole podstawowej}

Kształcenie w sferze przedsiębiorczości odgrywa obecnie ważną rolę w rozwijaniu społeczeństwa oraz w dynamizowaniu gospodarki. Początki edukacji w kierunku przedsiębiorczości sięgają lat 50. XX w. W 1947 r. w Stanach Zjednoczonych zorganizowano pierwszy na świecie kurs z problematyki przedsiębiorczości (Wach 2014).

Rozwijanie przedsiębiorczości obejmuje kształcenie formalne (edukacja szkolna), nieformalne i samokształcenie. Uczenie nieformalne obejmuje region kulturowy, zasady i wzorce społeczne oraz modele rodzinne. Tak pojmowana nauka wzmacnia motywację, stymuluje chęci i określa znaczenie przedsiębiorczości dla rozwoju jednostki oraz całego społeczeństwa.

W literaturze specjalistycznej wyodrębnia się trzy priorytety dotyczące nauczania przedsiębiorczości. Pierwszym z nich jest zdobywanie odpowiedniej wiedzy o przedsiębiorczości. Młodzież spotyka się z elementami, które mogą doprowadzić do osiągnięcia sukcesu. Drugi cel kształcenia w kierunku przedsiębiorczości związany jest z wypracowaniem wśród młodych ludzi postaw pozwalających otworzyć się na innowacje i konkurencyjność rynkową. Trzecia idea to przygotowanie uczniów do przyszłego funkcjonowania we współczesnym systemie gospodarczym. Odpowiednie kompetencje i cechy indywidualne są wymogiem skutecznego i prawdziwego rozwoju. Ważne jest, aby młodzież miała możliwość sprawdzenia tych trzech celów w działaniu, uzyskując odpowiedzi na nurtujące ją pytania (Jack i Anderson 1998; Chen i in. 1998; Gibb 1999; London i Smither 1999; Salomon i in. 2002).

W tym miejscu należy się zastanowić, czy edukacja geograficzna w zreformowanej szkole podstawowej daje możliwości, które pozwolą na wykształcenie u młodego człowieka postaw przedsiębiorczych. Czy wiedza i umiejętności zdobywane na tym etapie kształcenia przygotowują ucznia do przystosowania się do wyzwań współczesnej gospodarki?

W literaturze przedmiotu potwierdzone jest, że kompetencje osiągane na poszczególnych etapach kształcenia są niewystarczające i należy je ciągle uwspółcześniać. Kształtowanie postaw przedsiębiorczych 
na lekcjach geografii już od szkoły podstawowej wpływa na rozwijanie świadomości i potrzeby ciągłego aktualizowania wiedzy i uzyskiwania nowoczesnych umiejętności.

Cechy przedsiębiorcze obejmują nie tylko działalność człowieka, lecz także jego osobowość. Treści realizowane w nauczaniu geografii na etapie szkoły podstawowej mogą rozwijać takie atrybuty przedsiębiorczości jak: kreatywność, zaangażowanie, pracowitość, asertywność, uczciwość, umiejętność koncentracji, otwartość i pewność siebie. Młody człowiek, który od najmłodszych lat zdobywa wiedzę i określone umiejętności, podejmuje działania, osiąga sukcesy i jest otwarty na wyzwania, staje się osobą przedsiębiorczą (Borowiec, Rachwał 2011).

Kształcenie w obszarze przedsiębiorczości korzystnie wpływa na wszystkie dziedziny życia człowieka. Cechy przedsiębiorcze przydatne są nie tylko w działalności gospodarczej, lecz także w codziennym funkcjonowaniu. Ich doskonalenie motywuje i zachęca do działania, ale także rozwija aktywność i kreatywność.

Żeby uzyskać świadome implikacje, edukacja przedsiębiorcza powinna korelować z innymi przedmiotami. Przykładem takiego współdziałania są elementy z przedsiębiorczości, które można znaleźć w treściach geograficznych w zreformowanej szkole podstawowej. Geografia jest takim przedmiotem szkolnym, który wspierany przez otoczenie przekazuje wiedzę, kształci umiejętności i postawy bardzo zbliżone do wybranych treści z zakresu przedsiębiorczości. W efekcie powiązań międzyprzedmiotowych uczeń kształtuje swoją osobowość prywatną, społeczną i przedsiębiorczą.

Autorka publikacji dokonała analizy nowej podstawy programowej z geografii w ośmioletniej szkole podstawowej pod kątem szeroko pojętej przedsiębiorczości (tab. 1). 
Tabela 1. Cele kształcenia z geografii i treści kształcenia z elementami przedsiębiorczości

\begin{tabular}{|c|c|}
\hline $\begin{array}{l}\text { CELE KSZTAECENIA W NOWEJ } \\
\text { PODSTAWIE PROGRAMOWEJ }\end{array}$ & $\begin{array}{l}\text { TREŚCI KSZTAŁCENIA - WYMAGANIA SZCZEGółOWE, } \\
\text { W KTÓRYCH MOŻNA ZNALEŹĆ ELEMENTY PRZEDSIĘBIORCZOŚCI }\end{array}$ \\
\hline $\begin{array}{l}\text { Wiedza geograficzna } \\
\text { Poznanie zróżnicowa- } \\
\text { nych form działalności } \\
\text { człowieka w środowisku, } \\
\text { ich uwarunkowań i konse- } \\
\text { kwencji oraz dostrzeganie } \\
\text { potrzeby racjonalnego } \\
\text { gospodarowania zasoba- } \\
\text { mi przyrody }\end{array}$ & $\begin{aligned} \text { Uczeń: } \\
\rightarrow \text { opisuje zajęcia, tradycje rodzinne i zwyczaje mieszkańców wybra- } \\
\text { nych krain geograficznych Polski; } \\
\rightarrow \text { przedstawia pozytywne i negatywne zmiany w krajobrazach po- } \\
\text { wstałe w wyniku działalności człowieka; } \\
\rightarrow \text { przedstawia znaczenie nowoczesnego przemysłu i usług w gospo- } \\
\quad \text { darce na przykładzie Francji; } \\
\rightarrow \text { charakteryzuje przemiany w strukturze przemysłu w Niemczech } \\
\text { na przykładzie Nadrenii Północnej-Westfalii; } \\
\rightarrow \text { wyjaśnia przyczyny zmian w strukturze przemysłu Polski; } \\
\rightarrow \text { podaje przykłady różnych rodzajów usług w Polsce oraz ocenia } \\
\quad \text { znaczenie transportu i łączności dla jakości życia mieszkańców } \\
\text { i rozwoju gospodarczego naszego kraju; } \\
\rightarrow \text { podaje przykłady osiągnięć Polaków w różnych dziedzinach życia } \\
\quad \text { społeczno-gospodarczego oraz sukcesów polskich przedsiębiorstw } \\
\text { na arenie międzynarodowej; } \\
\rightarrow \text { przedstawia kierunki rozwoju gospodarczego Chin oraz ocenia ich } \\
\text { znaczenie w gospodarce światowej; } \\
\rightarrow \text { korzystając z danych statystycznych, określa rolę Stanów Zjedno- } \\
\quad \text { czonych w gospodarce światowej. }\end{aligned}$ \\
\hline $\begin{array}{l}\text { Identyfikowanie } \\
\text { współzależności między } \\
\text { elementami środowiska } \\
\text { przyrodniczego } \\
\text { i społeczno-gospodar- } \\
\text { czego oraz związków } \\
\text { i zależności w środowisku } \\
\text { geograficznym w skali } \\
\text { lokalnej, regionalnej } \\
\text { i globalnej }\end{array}$ & $\begin{array}{l}\text { Uczeń: } \\
\rightarrow \text { identyfikuje współzależności między składnikami poznawanych } \\
\text { krajobrazów i warunkami życia człowieka; } \\
\rightarrow \text { identyfikuje związki między przebiegiem autostrad i dróg ekspre- } \\
\text { sowych a lokalizacją przedsiębiorstw przemysłowych, centrów } \\
\text { logistycznych i handlowych w obszarze metropolitalnym Wrocławia } \\
\text { oraz między transportem morskim a lokalizacją inwestycji przemy- } \\
\text { słowych i usługowych na przykładzie Trójmiasta; } \\
\rightarrow \text { identyfikuje prawidłowości w rozmieszczeniu ludności i główne } \\
\text { cechy gospodarki Australii na tle warunków przyrodniczych; } \\
\rightarrow \text { charakteryzuje region Bliskiego Wschodu pod względem cech kul- } \\
\text { turowych oraz zasobów ropy naftowej i poziomu rozwoju gospodar- } \\
\text { czego. }\end{array}$ \\
\hline
\end{tabular}




\begin{abstract}
Określanie prawidłowości w zakresie przestrzennego zróżnicowania warunków środowiska przyrodniczego oraz życia i różnych form działalności człowieka
\end{abstract}

Uczeń:

$\rightarrow$ wykazuje zróżnicowanie środowiska przyrodniczego i charakteryzuje gospodarkę Rosji;

$\rightarrow$ wykazuje znaczenie poszczególnych sektorów gospodarki w rozwoju kraju oraz określa różnice w strukturze zatrudnienia ludności w Polsce i w wybranych państwach europejskich;

$\rightarrow$ wykazuje wpływ przemian politycznych i gospodarczych w Polsce po 1989 r. na zmiany struktury zatrudnienia na przykładzie konurbacji katowickiej i aglomeracji łódzkiej;

$\rightarrow$ na przykładzie Doliny Krzemowej wyjaśnia przyczyny rozwoju technopolii oraz jej znaczenie w rozwoju gospodarki opartej na wiedzy;

$\rightarrow$ określa cechy megalopolis w Ameryce Północnej oraz wyjaśnia przyczyny powstawania slumsów w wielkich miastach na przykładzie Ameryki Południowej;

$\rightarrow$ określa rolę tradycyjnych i nowoczesnych działów gospodarki w rozwoju wybranych krajów Afryki;

$\rightarrow$ określa możliwości rozwoju gospodarczego Indii oraz przedstawia kontrasty społeczne w tym kraju.

\section{Umiejętności i stosowa- nie wiedzy w praktyce Ocenianie zjawisk i proce- sów społeczno-kulturo- wych oraz gospodarczych zachodzących w Polsce i w różnych regionach świata}

Uczeń:

$\rightarrow$ prezentuje niektóre przykłady budownictwa, sposobów gospodarowania, głównych zajęć mieszkańców poznawanych obszarów;

$\rightarrow$ ocenia możliwości rozwoju gospodarki morskiej w Polsce;

$\rightarrow$ identyfikuje związki między rozwojem dużych miast a zmianami w strefach podmiejskich w zakresie użytkowania i zagospodarowania terenu, stylu zabudowy oraz struktury ludności na przykładzie obszarów metropolitalnych Warszawy i Krakowa.
Stawianie pytań, formułowanie hipotez oraz proponowanie rozwiązań problemów dotyczących środowiska geograficznego
Uczeń:

$\rightarrow$ analizuje i porównuje konsekwencje stosowania różnych metod ochrony przeciwpowodziowej oraz określa wpływ zabudowy obszarów zalewowych i sztucznych zbiorników wodnych na występowanie i skutki powodzi na przykładzie Dolnego Śląska i Małopolski;

$\rightarrow$ analizuje warunki przyrodnicze i pozaprzyrodnicze sprzyjające lub ograniczające produkcję energii ze źródeł nieodnawialnych i odnawialnych oraz określa ich wpływ na rozwój energetyki na przykładzie województw pomorskiego i łódzkiego.

\begin{tabular}{|c|c|}
\hline $\begin{array}{l}\text { Podejmowanie nowych } \\
\text { wyzwań oraz racjonalnych } \\
\text { działań prośrodowisko- } \\
\text { wych i społecznych }\end{array}$ & $\begin{array}{l}\text { Uczeń: } \\
\rightarrow \text { projektuje trasę wycieczki po Litwie i Białorusi uwzględniającej } \\
\text { wybrane walory środowiska przyrodniczego i kulturowego. }\end{array}$ \\
\hline $\begin{array}{l}\text { Podejmowanie kon- } \\
\text { struktywnej współpracy } \\
\text { i rozwijanie umiejętno- } \\
\text { ści komunikowania się } \\
\text { z innymi }\end{array}$ & $\begin{array}{l}\text { Uczeń: } \\
\rightarrow \text { przedstawia w dowolnej formie (np. prezentacji multimedialnej, } \\
\text { plakatu, filmu, wystawy fotograficznej) przyrodnicze i kulturowe } \\
\text { walory regionu; } \\
\rightarrow \text { projektuje trasę wycieczki krajoznawczej po własnym regionie na } \\
\text { podstawie wyszukanych źródeł informacji oraz w miarę możliwości } \\
\text { przeprowadza ją w terenie; } \\
\rightarrow \text { dyskutuje na temat form współpracy między własnym regionem } \\
\text { a partnerskimi regionami zagranicznymi; } \\
\rightarrow \text { przedstawia w dowolnej formie (np. prezentacji multimedialnej, } \\
\text { plakatu, filmu, wystawy fotograficznej) atrakcyjność „małej ojczyzny” } \\
\text { jako miejsca zamieszkania i działalności gospodarczej na podstawie } \\
\text { informacji wyszukanych w różnych źródłach. }\end{array}$ \\
\hline
\end{tabular}




\begin{tabular}{|c|c|}
\hline $\begin{array}{l}\text { Wykorzystywanie zdoby- } \\
\text { tej wiedzy i umiejętności } \\
\text { geograficznych w życiu } \\
\text { codziennym }\end{array}$ & $\begin{array}{l}\text { Uczeń: } \\
\rightarrow \text { dokonuje oceny krajobrazu najbliższego otoczenia szkoły pod } \\
\text { względem jego piękna oraz ładu i estetyki zagospodarowania } \\
\text { podczas zajęć realizowanych w terenie oraz proponuje zmiany } \\
\text { w jego zagospodarowaniu; } \\
\rightarrow \text { wyznacza w terenie współrzędne dowolnych punktów (za pomocą } \\
\text { mapy lub GPS); } \\
\rightarrow \text { rozpoznaje w terenie główne obiekty charakterystyczne } \\
\text { dla „małej ojczyzny” i decydujące o jej atrakcyjności; } \\
\rightarrow \text { projektuje na podstawie własnych obserwacji terenowych działania } \\
\text { służące zachowaniu walorów środowiska geograficznego (przy- } \\
\text { rodniczego i kulturowego) oraz poprawie warunków życia lokalnej } \\
\text { społeczności. }\end{array}$ \\
\hline $\begin{array}{l}\text { Kształtowanie postaw } \\
\text { Rozpoznawanie swoich } \\
\text { predyspozycji i talentów } \\
\text { oraz rozwijanie pasji } \\
\text { i zainteresowań geogra- } \\
\text { ficznych }\end{array}$ & $\begin{array}{l}\text { Uczeń: } \\
\rightarrow \text { przyjmuje postawę współodpowiedzialności za stan środowiska } \\
\text { przyrodniczego Polski, } \\
\rightarrow \text { jest świadomy tego, że może mieć w przyszłości wpływ na rozwój } \\
\text { społeczno-gospodarczy i kulturowy Polski. }\end{array}$ \\
\hline
\end{tabular}

Źródło: Opracowanie własne na podstawie rozporządzenia w sprawie podstawy programowej wychowania przedszkolnego oraz kształcenia ogólnego dla szkoły podstawowej z dnia 14 lutego 2017 r.

Po przeanalizowaniu nowej podstawy programowej z geografii w szkole podstawowej można zauważyć, że z elementami przedsiębiorczości wiąże się dużo treści kształcenia. Proces nabywania wiedzy i kształtowania umiejętności przedsiębiorczych może być realizowany w ramach tematów z zakresu wiedzy geograficznej, stosowania tej wiedzy w praktyce oraz kształtowania postaw. Na każdej z tych trzech płaszczyzn znajdziemy treści nauczania z zakresu geografii gospodarczej Polski, Europy i całego świata. Obecnie zagadnienia z przedsiębiorczości w geografii szkoły podstawowej będzie można realizować, dokonując charakterystyki gospodarczej wybranych krajów świata, z włączeniem Polski. Podczas uczenia wiedzy geograficznej treści przedsiębiorczości mogą być wyodrębnione podczas omawiania zmian w gospodarce Polski oraz wybranych krajów świata, m.in. Francji, Niemiec, Chin, Stanów Zjednoczonych.

W obszarze stosowania wiadomości i umiejętności w praktyce uczeń może zrozumieć wpływ różnych czynników na funkcjonowanie danego regionu poprzez: 
$\rightarrow$ ocenę zjawisk i procesów (np. przykłady budownictwa, sposoby gospodarowania i użytkowania określonych rejonów Polski i świata),

$\rightarrow$ stawianie pytań i samodzielne poszukiwanie odpowiedzi (np. wpływ warunków pozaprzyrodniczych na rozwój energetyki w Polsce),

$\rightarrow$ podejmowanie wyzwań i działań (np. projektowanie trasy wycieczki do określonego miejsca w Polsce lub na świecie),

$\rightarrow$ podejmowanie współpracy i komunikowanie się (np. prezentacje multimedialne, plakaty, filmy, wystawy dotyczące wybranych form działalności człowieka),

$\rightarrow$ wykorzystywanie wiedzy i umiejętności w życiu codziennym (np. ocena walorów pozaprzyrodniczych mających wpływ na rozwój najbliższego otoczenia).

Trzecim celem kształcenia geograficznego, w którym możemy wyodrębnić elementy z przedsiębiorczości, jest rozpoznawanie swoich predyspozycji i talentów. W tej sferze uczeń może zostać wyposażony w postawy przedsiębiorcze takie jak: pracowitość, odpowiedzialność, aktywność, umiejętność współpracy.

Nauczanie przedsiębiorczości polega na rozbudzaniu myślenia kreatywnego, rozwiązywania problemów w sposób konstruktywny, sprawnej komunikacji, dynamicznego szukania informacji, demonstracji uzyskanych informacji. Ucząc geografii w szkole podstawowej, można uczyć przedsiębiorczości. Na podstawie analizy podstawy przedsiębiorczej widać wyraźnie, że z powodzeniem na lekcjach geografii da się działać przedsiębiorczo. Wynika z tego, że nauczyciele przedmiotów nie tylko ekonomicznych mogą, a nawet we współczesnych realiach powinni, odwoływać się do przedsiębiorczości wszędzie tam, gdzie jest taka możliwość.

Dotychczas trudno było znaleźć treści kształcenia odnoszące się do przedsiębiorczości w szkole podstawowej. Treści te zaczynały być widoczne dopiero w gimnazjum. Nowa reforma, przywracając geografię do drugiego etapu kształcenia, daje możliwość nie tylko realizacji treści przedsiębiorczych na lekcjach, lecz także szansę na podejmowanie przez uczniów różnorodnych inicjatyw przedsiębiorczych. Jednym z przykładów takiej koncepcji przedsiębiorczej byłoby poprowadzenie przez uczniów na terenie szkoły wybranej działalności 
gospodarczej. Pod opieką nauczyciela uczniowie mogliby prowadzić na przykład sklepik szkolny. Taka propozycja rozwija nie tylko postawy przedsiębiorcze, lecz także wychowawcze. Dzieci w wieku 10-14 lat mogą już rozwijać swoją odkrywczość, pomysłowość, samodzielność, mądrość i komunikatywność. Taki rodzaj inicjatywy zwiększa osobiste talenty, zachęca do przedsiębiorczości, ale także zmienia mentalność młodych ludzi.

Inną formą realizacji przedsiębiorczości w geografii jest promocja postaw przedsiębiorczych poprzez przygotowywanie prezentacji i przedstawianie ich przed klasą lub całą społecznością szkolną. Podczas wykonywania pokazu dziecko zaczyna myśleć przedsiębiorczo, wykorzystując wiedzę i umiejętności w działaniu. Przykładami takich przedsięwzięć mogą być prezentacje dotyczące najbliższego otoczenia, "małej ojczyzny", ale także wybranych miast Polski lub całego świata. Na poziomie szkoły podstawowej udział uczniów w prezentacjach rozwija kreatywność, ale także samodzielność. Wypracowuje się ważny element postawy przedsiębiorczej, a mianowicie pracowitość. To właśnie ona może najbardziej zaprocentować w byciu osobą przedsiębiorczą.

Edukacja w Polsce nadal zawiera więcej wiedzy niż praktyki. Poprzez ćwiczenia praktyczne możemy dochodzić do określonej wiedzy i formułować definicje. W taki sposób rozwija się postawy przedsiębiorcze i poznaje potencjał młodego człowieka. $Z$ doświadczenia autorki publikacji wynika, że najlepszą formą wykorzystywania wiedzy w praktyce są lekcje prowadzone metodą projektu. Na lekcjach geografii ta metoda pracy jest znana, ale w szkole podstawowej nadal rzadko stosowana. Geografia jako przedmiot szkolny daje bardzo duże możliwości stosowania metody projektu w praktyce. Przedsięwzięcia mogą objąć jedną klasę lub kilka, ale także całą społeczność szkolną. Treści prezentowane w projekcie mogą być związane z geografią, ale również z innymi przedmiotami szkolnymi. Przykładem realizacji metody projektu na geografii w szkole podstawowej jest temat "Sąsiedzi Polski", który został zrealizowany przez autorkę publikacji w roku szkolnym 2017/2018. Projekt został przygotowany przez klasy VII i zaprezentowany całej społeczności szkolnej. Wspólna praca przy realizacji inicjatywy rozwija aktywność, kreatywność, myślenie, a także działania interpersonalne. Metoda projektu przygotowuje uczniów do praktycznego działania i daje dużą skuteczność w nauczaniu. Cytując Konfucjusza: „Usłyszałem - zapomniałem, zobaczyłem - zapamiętałem, zrobiłem - zrozumiałem", 
znajduje się potwierdzenie, że nauka szkolna winna być nastawiona głównie na praktykę, a nie na teorię.

\section{Podsumowanie}

Nauczanie przedsiębiorczości to ciągłe i systematyczne kształtowanie innowacyjności i odkrywczości. Szkoła musi współtworzyć relacje z otoczeniem i przygotowywać młodych ludzi do życia w warunkach konkurencyjnej gospodarki. Dobra edukacja, obejmująca także kształtowanie postaw przedsiębiorczych, wpływa nie tylko na możliwość osiągnięcia sukcesu w życiu zawodowym i prywatnym młodych ludzi, lecz także na szeroko rozumiany dobrobyt.

Przedsiębiorczość jako przedmiot szkolny pojawia się w nowej podstawie programowej dopiero na trzecim etapie edukacji. Dlatego są potrzebne na wcześniejszych etapach edukacji takie przedmioty jak geografia, na których kształtowane będą odpowiednie cechy u dzieci. Dzięki geografii uczniowie nabywają umiejętności planowania swojej przyszłości i aktywności w działaniu. Kształtowanie postaw przedsiębiorczych na lekcjach geografii opiera się na zasobach teoretycznych i uruchamia stosowanie wiedzy w życiu codziennym. Służy to rozwojowi osobowości człowieka, ale też ma wpływ na przyszłość i dobrą jakość życia społecznego.

Przesłankami przemawiającymi za realizacją treści przedsiębiorczych na geografii w szkole podstawowej są bliski zakres treściowy oraz zbieżność celów edukacyjnych tych przedmiotów.

Zdaniem autorki niniejszej publikacji zagadnienia przedsiębiorcze są mocno powiązane z treściami geograficznymi w zreformowanej szkole podstawowej. Edukacja przedsiębiorcza realizowana na drugim etapie edukacji może wspierać i udoskonalać ucznia. Otwartość, aktywność, pomysłowość, a także pracowitość i sumienność tworzą człowieka przedsiębiorczego w XXI w. 


\section{Bibliografia}

$\rightarrow$ Borowiec, M., Rachwał, T. (2011), Kształtowanie postaw przedsiębiorczych na lekcjach geografii wyzwaniem edukacyjnym w procesach globalizacji, „Przedsiębiorczość - Edukacja", nr 7, s. 321-332.

$\rightarrow$ Chen, C.A., Greene, P.G., Crick, A. (1998), Does entrepreneurial efficacy distinguish entrepreneurs from managers?, "Journal of Business Venturing”, nr 13, s. 295-316.

$\rightarrow$ Gibb, A. (1999), Can we build effective entrepreneurship through management development, „Journal of General Management”, nr 24 (4), s. 1-21.

$\rightarrow$ Grodzicki, J. (2000), Edukacja czynnikiem rozwoju gospodarczego, Toruń: Wydawnictwo Adam Marszałek.

$\rightarrow$ Jack, S.L., Anderson, A.R. (1998), Entreprenurship education within the condition of entreprenology. Second Enterprise an Learning Conference, Centre for Entrepreneurship, Aberdeen: University of Aberdeen.

$\rightarrow$ Kabaj, M. (1997), W kierunku gospodarki opartej na wiedzy, „Polityka Społeczna", nr 4.

$\rightarrow$ Kets de Vries, F.R. (1985), The dark side of entrepreneurship " "Harvard Business Review", nr 6.

$\rightarrow$ Kurczewska, A. (2010), Problemy pomiaru intencji przedsiębiorczych, „E-mentor", $\mathrm{nr} 4$ (36).

$\rightarrow$ London, M., Smither, J.W. (1999), Empowered self-development and continuous learning, „Human Resource Management”, nr 38 (1), s. 3-15.

$\rightarrow$ Otoliński, E. (1996), Istota i kreowanie przedsiębiorczości, „Przegląd Organizacji", nr 6.

$\rightarrow$ Rozporządzenie w sprawie podstawy programowej wychowania przedszkolnego oraz kształcenia ogólnego dla szkoły podstawowej z dnia 14 lutego 2017 r.

$\rightarrow$ Safin, K. (2004), Uwarunkowania rozwoju przedsiębiorczości-próba systematyzacji [w:] K. Jaremczuk (red.), Uwarunkowania przedsiębiorczości, Tarnobrzeg: Wydawnictwo PWSZ, s. 45. 
$\rightarrow$ Salomon, G.T., Duffy, S., Tarabishy, A. (2002), The state of entrepreneurship education in the United States: a nationwide survey and analysis, "International Journal of Entrepreneurship Education", nr 1 (1), s. 65-86.

$\rightarrow$ Shapero, A., Sokol, L. (1982), Social dimensions of entrepreneurship, [w:] C.A. Kent, D.L. Sexton, K.H. Vesper (red.), Encyclopedia of entrepreneurship, University of Illinois: Prentice Hall, s. 72-90.

$\rightarrow$ Wach, K. (2014), Europeanisation of Entrepreneurship Education in Europe - Looking Back and Looking Forward, „Horyzonty Wychowania”, nr 13 (26), s. 11-31.

$\rightarrow$ Wieloński, A. (2003), Przemysł nowej gospodarki, „Prace Komisji Geografii Przemysłu Polskiego Towarzystwa Geograficznego", nr 6, s. 21-26.

$\rightarrow$ Zajączkowska-Jakimiak, S. (2002), Wiedza i technologia w erze globalizacji, [w:] Globalizacja, mechanizmy i wyzwania, B. Liberska (red.), Warszawa: PWE. 


\section{Netografia}

$\rightarrow$ National Content Standards for Entrepreneurship Education: Nurturing the Entrepreneurial Spirit, www.entre-ed.org/Standarts_Toolkit/nurturing.html [dostęp 8.10.2018]. 


\title{
Przedsiębiorczość w szkole średniej w warunkach reformy systemu oświaty
}

\author{
Wioletta Kilar, Tomasz Rachwał
}

W rozdziale przedstawiono wyniki analizy zapisów nowej podstawy programowej kształcenia ogólnego dla szkół średnich w zakresie podstaw przedsiębiorczości na tle dotychczas obowiązującej podstawy. Wskazano na podobieństwa w zakresie liczby godzin przeznaczonych na realizację tego przedmiotu i na zasadnicze różnice w zakresie zapisów celów kształcenia - wymogów ogólnych, które w nowej podstawie zostały zapisane bardziej recyzyjnie i podzielone na trzy kategorie: w zakresie wiedzy, umiejętności i kształtowania postaw. W drugiej części pracy określono różnice i podobieństwa w zakresie podziału treści kształcenia na działy oraz zmiany w zakresie zapisów wymagań szczegółowych, kładąc szczególny nacisk na efekty kształcenia określane jako „innowacyjne”.

\section{Słowa kluczowe:}

edukacja w zakresie przedsiębiorczości

innowacyjne treści kształcenia

podstawa programowa

postawa przedsiębiorcza

reforma oświaty

szkoła średnia 


\section{Entrepreneurship in secondary school and educational system reform}

Wioletta Kilar, Tomasz Rachwał

The chapter presents the results of the analysis of the new core curriculum of general education for secondary schools in the field of entrepreneurship in the context of the current curriculum. The similarities in the number of hours allocated for this subject and the fundamental differences in the scope of learning objectives - general requirements, which in the new basis have been written more concretely and divided into three categories: in terms of knowledge, skills and attitudes, were pointed out. The second part of paper identifies the differences and similarities in the division of educational content into sections and changes in the scope of specific requirements, placing particular emphasis on learning outcomes referred to as "innovative".

\section{Keywords:}

education in the field of entrepreneurship

innovative content of education

core curriculum

entrepreneurial attitude

education reform

high school 


\section{Wstęp}

Szybko zmieniająca się otoczenie społeczno-gospodarcze w wyniku przechodzenia $z$ industrialnej przez postindustrialną do informacyjnej fazy rozwoju cywilizacyjnego oraz budowy gospodarki opartej na wiedzy, stwarza nowe uwarunkowania funkcjonowania człowieka na rynku pracy i w życiu prywatnym. Wyzwaniem zarówno dla młodzieży, jak i osób dorosłych jest nie tylko umiejętność odnalezienia się $w$ tej podlegającej dynamicznym przemianom rzeczywistości, ale także konkurowania na rynku międzynarodowym. Wynika to z nasilającej się presji konkurencyjnej, u podstaw której leży liberalizacja przepisów w zakresie przepływu zasobów pracy, towarów, usług i kapitału. Ponadto wiele regionów i państw świata, także Europy dotykają różnego typu kryzysy polityczne, społeczne i gospodarcze, co powoduje, że funkcjonujemy w turbulentnych warunkach otoczenia.

Czynnikiem sprzyjającym przygotowaniu do życia w tych nowych, zmieniających się uwarunkowaniach jest dobre wykształcenie, szczególnie w zakresie tych umiejętności i postaw, które stanowią bazę dla funkcjonowania i współdziałania w życiu prywatnym i zawodowym. Szczególnie ważne jest tu kształcenie w zakresie przedsiębiorczości, która w szerokim rozumieniu tego pojęcia, jest obecnie jedną z fundamentalnych kompetencji każdego człowieka, na co wskazuje wielu autorów (Borowiec-Gabryś, Kilar, Rachwał 2018, Kalita 2014, Piróg 2015, Rachwał $i$ in. 2018, Wach 2013, 2014).

Przedsiębiorczość, jako jedna z tzw. kompetencji kluczowych (Kompetencje kluczowe... 2005), jest konieczna by odnaleźć się we współczesnym, szybko zmieniającym się i bardzo często turbulentnym świecie. Jej kształtowaniu w znacznym stopniu sprzyja edukacja w zakresie przedsiębiorczości od jak najniższych etapów kształcenia, której głównym celem jest przygotowanie młodych ludzi do aktywnego i świadomego uczestnictwa w życiu społeczno-gospodarczym, do wykorzystywania szans obecnych w otoczeniu i podejmowania kreatywnych (innowacyjnych) działań lub projektów oraz do ewentualnego podjęcia własnej działalności gospodarczej. Stanowi to poważne wyzwanie dla osób odpowiedzialnych za system edukacji, w szczególności za jej aspekt programowy. Niezbędna jest bowiem systematyczna modernizacja programów kształcenia w zakresie celów, zakresu treści i stosowanych metod, aby sprostać tym wyzwaniom i zapotrzebowaniu w zakresie edukacji. 
W świetle tych przesłanek celem pracy jest przedstawienie wyników analizy zapisów nowej podstawy programowej w zakresie przedsiębiorczości dla szkół średnich w związku z wdrażaną reformą systemu oświaty w Polsce. W szczególności dokonano porównania działów (grup treści kształcenia), realizowanych lub zaplanowanych do realizacji w ramach przedmiotu podstawy przedsiębiorczości, które zostały zapisane w starej (z 2012 r.) i nowej (z 2018 r.) podstawie programowej, a także przyjętych celów ogólnych oraz szczegółowych. W pracy zmierzać się będzie również do wskazania innowacyjnych treści kształcenia i umiejętności, które zostały wprowadzone do nowej podstawy programowej w ramach reformy edukacji w Polsce w kontekście wyzwań cywilizacyjnych XXI w. Analizie poddano zapisy starych i nowych podstaw programowych dla liceum ogólnokształcącego, technikum oraz szkół branżowych I stopnia, dotychczas szkół zawodowych (Rozporzq̨dzenie MEN 2012, 2018a, b). Rozważania oparte są na wynikach prowadzonych badań przy wykorzystaniu kilku podstawowych metod tj. kwerendy i analizy literatury przedmiotu oraz analizy treści i analizy danych zastanych (desk research).

\section{Kształcenie w zakresie przedsiębiorczości w Polsce w świetle literatury przedmiotu}

Problematyka kształcenia w zakresie przedsiębiorczości podejmowana jest szeroko zarówno w literaturze krajowej, jak i zagranicznej. Autorzy koncentrujący się na procesie edukacji w tym zakresie w Polsce, pośród różnych zagadnień podkreślają między innymi potrzebę rozszerzania wiedzy i umiejętności w zakresie przedsiębiorczości u młodych ludzi na niższych niż uniwersytecki poziomach kształcenia. Upatrują w tym procesie możliwości zrozumienia i właściwej reakcji na szybko zmieniające się uwarunkowania społeczno-gospodarcze, w których współcześnie dorastają i będą w przyszłości funkcjonowali dzisiejsi uczniowie (Zioło 2009, 2012, Borowiec, Rachwał 2011). Wskazują także na konieczność zwrócenia większej uwagi na umiejętności i postawy związane z przedsiębiorczością, gdyż w warunkach polskich przez wiele lat w edukacji na poziomie średnim (gimnazjum i szkoła ponadgimnajzalna) dominowało wyposażenie uczniów w wiedzę ekonomiczną (Rachwał, Kurek, Boguś 2016). Podejmowano także problematykę kryteriów doboru celów i treści nauczania do podstawy programowej i programu nauczania 
z podstaw przedsiębiorczości (Rachwał 2004, Tracz 2005), statusu, miejsca, roli i rangi przedsiębiorczości w edukacji (Brzozowski 2013, Kawecki 2005, Tracz 2006, Zioło 2012) oraz analizy wyników badań opinii uczniów, nauczycieli i rodziców na temat realizacji przedmiotu podstawy przedsiębiorczości (Osuch E., Osuch W. 2006, Osuch 2012, Sowislok 2012, Ziółkowska-Weiss 2014, 2016). Ważnym przedmiotem badań było także przygotowanie nauczycieli tego przedmiotu (Tracz, Rachwał 2007), ich skuteczność jako wychowawców (Czechowski 2014) oraz stosowane przez nich metody nauczania i wykorzystywane środki dydaktyczne (Gaweł 2014, Kilar i in 2016, Kulikowska, Krasnodębska 2007, Łazowska 2005, Śrutowska 2006, Tracz, Rachwał 2008, Żur 2014).

W sytuacji ciągłych zmian w gospodarce i uwarunkowań prawnych podejmowania pracy najemnej i prowadzenia działalności gospodarczej, naturalnym przedmiotem zainteresowania badaczy są podejmowane próby zmian podstaw programowych kształcenia w zakresie przedmiotu (np. Górz, Rachwał 2006, Rachwał 2006, 2009, 2017, Wach 2012). Przedstawiano także propozycje nowej podstawy programowej w zakresie rozszerzonym (Rachwał i in. 2008), co dawałoby możliwość wprowadzenia podstaw przedsiębiorczości jako przedmiotu maturalnego do wyboru (Bartoń 2005). Podejmowana była także problematyka metod badań edukacji przedsiębiorczej (2016) oraz analizy bibliometrycznej polskiego piśmiennictwa odnoszącego się do edukacji w zakresie przedsiębiorczości (Wach 2016).

\section{Miejsce przedsiębiorczości w polskim systemie edukacji}

Edukacja w zakresie przedsiębiorczości w polskim systemie edukacji jest ważnym elementem kształcenia, choć nie ma to bezpośredniego odzwierciedlenia w liczbie godzin na realizację przedmiotu podstawy przedsiębiorczości. Oprócz tego, że pomaga zrozumieć otaczający młodego człowieka świat, na podkreślenie zasługuje fakt, że jest jedynym przedmiotem szkolnym w zakresie edukacji ekonomicznej młodzieży w Polsce. Zatem daje podstawy wiedzy i umiejętności z zakresu podstaw ekonomii, finansów, a także przygotowania do pracy zawodowej, w tym zakładania własnego biznesu.

Przedsiębiorczość, jako oddzielny obowiązkowy przedmiot szkolny został wprowadzony do szkół ponadgimnazjalnych w roku szkolnym 2002/2003, pod nazwą podstawy przedsiębiorczości. Była to decyzja 
podjęta w trakcie reformy, której wdrażanie rozpoczęto w 1999 r. Początkowo w ramach kształcenia ogólnego przedmiot był realizowany podczas dwóch godzin tygodniowo i w zależności od decyzji szkoły mógł być nauczany w jednej klasie (1 rok) w wymiarze dwóch godzin lub przez dwa lata w wymiarze 1 godz. tygodniowo.

Podczas kolejnej reformy z 2008 r. podtrzymano założenia, że podstawy przedsiębiorczości, jako obowiązkowy przedmiot szkolny, realizowane były w cyklu 60 godz. ( 1 klasa, 2 godz. tygodniowo). Jednocześnie na III etapie edukacyjnym, czyli w gimnazjum, część treści z zakresu podstaw przedsiębiorczości została wpisana również do podstawy programowej z wiedzy o społeczeństwie. Równolegle wprowadzono fakultatywny przedmiot szkolny ekonomia w praktyce, który według założeń był ściśle powiązany z podstawami przedsiębiorczości (Borowiec-Gabryś, Kilar, Rachwał 2018).

W założeniach obecnej, tj. wdrażanej od 2017 r. reformy, podtrzymana została liczba godzin w całym cyklu kształcenia, natomiast przedmiot ten będzie realizowany $w$ drugiej i trzeciej klasie liceum i technikum oraz w pierwszej klasie szkoły branżowej I stopnia (Rozporzq̨dzenie MEN..., 2017). W szkołach policealnych będzie realizowany tylko w sytuacji, gdy uczniowie nie mieli go na niższych poziomach edukacji. Natomiast dotychczasowy przedmiot fakultatywny ekonomia w praktyce, nie występuje już w ofercie przedmiotów do wyboru. $\mathrm{Na}$ wcześniejszym etapie edukacyjnym, tj. w szkole podstawowej, w niewielkim zakresie treści dotyczące przedsiębiorczości realizowane są na wiedzy o społeczeństwie oraz jednostkowo na innych przedmiotach (zobacz jeden z wcześniejszych rozdziałów autorstwa W. Kilar i T.Rachwała oraz Kilar i in. 2018). Co istotne, w nowej podstawie programowej z podstaw przedsiębiorczości dla szkół ponadpodstawowych (zgodnie z harmonogramem wdrażania reformy będzie obowiązywać od roku szkolnego 2019/2020) przyjęto, że jednym z głównych celów dydaktycznych przedmiotu jest przygotowanie uczniów do planowania swojej przyszłości oraz do aktywności zawodowej w roli pracowników najemnych lub osób prowadzących własną działalność gospodarczą. Ma to sprzyjać przygotowaniu uczniów do aktywności społecznej i gospodarczej, a także do życia rodzinnego w znaczeniu ekonomicznym, dając podstawowe umiejętności konkurencyjnych zachowań na rynku, w tym ponoszenia konsekwencji swoich decyzji (Rozporzq̨dzenie MEN... 2018, Kilar i in. 2018). 


\section{Zmiany w podstawie programowej dla szkół średnich}

W nowej podstawie programowej utrzymano dotychczasową formę zapisu, na którą składają się:

$\rightarrow$ wstęp, w którym uzasadniono cele realizacji przedmiotu,

$\rightarrow$ cele kształcenia - wymagania ogólne, czyli podstawowe cele, jakie $w$ toku edukacji powinno się osiągnąć,

$\rightarrow$ treści nauczania - wymagania szczegółowe, które w sposób możliwie precyzyjny podają jakie treści powinny być realizowane i jakie efekty kształcenia osiągnięte,

$\rightarrow$ warunki realizacji w szkole.

Tak jak w poprzedniej podstawie programowej utrzymano styl zapisów wymagań szczegółowych w "języku efektów kształcenia”, jak to jest powszechnie stosowane w krajach Unii Europejskiej. Stanowi to $z$ jednej strony pewne ograniczenie w zakresie możliwości ogólnego sformułowania wymagania, ale $z$ drugiej strony dzięki temu zapisy precyzyjnie wyrażają, co nauczyciel ma osiągnąć z uczniami.

W świetle przyjętej koncepcji przedmiot podstawy przedsiębiorczości stanowi zatem syntezę wybranych celowo elementów wiedzy z zakresu ekonomii, zarządzania i finansów, wzbogaconej elementami geografii społeczno-ekonomicznej, politologii, socjologii, psychologii oraz prawa. W ramach lekcji podstaw przedsiębiorczości uczniowie zapoznają się z podstawowymi kategoriami, mechanizmami i procesami ekonomicznymi oraz ich uwarunkowaniami instytucjonalnymi, behawioralnymi, kulturowymi i rynkowymi. Postawy przedsiębiorcze i wspierające je umiejętności powinny zatem pośrednio z tej wiedzy wynikać. W procesie kształcenia uczniowie dowiadują się, jak - realizując indywidualne cele ekonomiczne - być przedsiębiorczym, a zarazem społecznie odpowiedzialnym w swoich dążeniach i działaniach (Rozporzqdzenie MEN... 2018).

\section{Cele kształcenia w podstawach programowych dla szkół średnich}

W stosunku do podstawy programowej dotychczas obowiązującej nastąpiła znaczna zmiana układu treści ogólnych celów kształcenia (Tabela 1). Dotychczas bowiem miały one nieco odmienny charakter, gdyż w wymaganiach ogólnych wyróżniono działy grupujące treści kształcenia: komunikacja i podejmowanie decyzji, gospodarka i przedsiębior- 
stwo, planowanie i kariera zawodowa oraz ostatni - zasady etyczne. Dotychczas cele ogólne zapisane były łącznie dla różnych kategorii. Jednak, ze względu na specyfikę przedmiotu korzystniejsze wydaje się, podzielenie celów ogólnych na kategorie: wiedza, umiejętności i stosowanie wiedzy w praktyce oraz kształtowanie postaw, jak to zapisano w nowej podstawie programowej. Zastosowane ujęcie podkreśla, często pomijaną, rolę umiejętności oraz postaw w kształceniu i codziennym życiu młodego człowieka, na co wcześniej zwracał uwagę m.in. T. Rachwał $(2005,2006)$. Podobny sposób zapisu został przyjęty m.in. w podstawie programowej z geografii (Rozporzq̨dzenie MEN... 2018a, Szkurłat $\mathrm{i}$ in. 2018).

Tabela 1. Cele kształcenia - wymagania ogólne w starej i nowej podstawie programowej

\begin{tabular}{|c|c|}
\hline NOWA PODSTAWA PROGRAMOWA DO SZKÓt ŚREDNICH* & $\begin{array}{l}\text { STARA PODSTAWA PROGRAMOWA DO SZKót } \\
\text { ŚREDNICH** }\end{array}$ \\
\hline \multicolumn{2}{|c|}{ I. WIEDZA. } \\
\hline $\begin{array}{l}\text { 1. Poznanie elementarnych pojęć z zakresu podstaw } \\
\text { przedsiębiorczości. }\end{array}$ & nie występuje \\
\hline $\begin{array}{l}\text { 2. Rozumienie istoty przedsiębiorczości oraz pozna- } \\
\text { nie jej roli w gospodarce i życiu człowieka. }\end{array}$ & nie występuje \\
\hline $\begin{array}{l}\text { 3. Wyjaśnianie mechanizmów funkcjonowania go- } \\
\text { spodarki rynkowej, powiązań między jej podmiotami } \\
\text { oraz poznanie roli państwa w procesach gospodar- } \\
\text { czych. }\end{array}$ & $\begin{array}{l}\text { [Uczeń] charakteryzuje mechanizmy } \\
\text { funkcjonowania gospodarki i instytucji } \\
\text { rynkowych oraz rolę państwa w gospo- } \\
\text { darce. }\end{array}$ \\
\hline $\begin{array}{l}\text { 4. Zaznajomienie się z prawami i instytucjami chro- } \\
\text { niącymi konsumenta. }\end{array}$ & nie występuje \\
\hline $\begin{array}{l}\text { 5. Rozumienie roli pieniądza, rynków i instytucji } \\
\text { finansowych w gospodarce, funkcjonowaniu przed- } \\
\text { siębiorstw i życiu człowieka. }\end{array}$ & nie występuje \\
\hline $\begin{array}{l}\text { 6. Poznanie rodzajów podatków, ich wpływu na } \\
\text { budżety państwa, przedsiębiorstw i gospodarstw } \\
\text { domowych. }\end{array}$ & nie występuje \\
\hline $\begin{array}{l}\text { 7. Dostrzeganie znaczenia ubezpieczeń w działalno- } \\
\text { ści gospodarczej i życiu człowieka. }\end{array}$ & nie występuje \\
\hline $\begin{array}{l}\text { 8. Rozumienie funkcjonowania rynku pracy, zasad } \\
\text { aktywnego poszukiwania pracy, przygotowania się } \\
\text { do rozmowy kwalifikacyjnej, poznanie praw oraz } \\
\text { obowiązków pracownika i pracodawcy. }\end{array}$ & nie występuje \\
\hline
\end{tabular}




\begin{tabular}{l|l}
\hline $\begin{array}{l}\text { 9. Poznanie zasad funkcjonowania przedsiębiorstwa } \\
\text { w gospodarce rynkowej, form organizacyjno-praw- } \\
\text { nych, innowacyjnych modeli biznesowych i procedu- } \\
\text { ry rejestracji działalności gospodarczej. }\end{array}$ & $\begin{array}{l}\text { [Uczeń] wyjaśnia zasady funkcjonowa- } \\
\text { nia przedsiębiorstwa i sporządza prosty } \\
\text { biznesplan. }\end{array}$ \\
\hline $\begin{array}{l}\text { 10. Rozumienie zasad zarządzania, roli marketingu } \\
\text { oraz społecznej odpowiedzialności w funkcjonowa- } \\
\text { niu przedsiębiorstwa. }\end{array}$ & nie występuje \\
\hline
\end{tabular}

II. UMIEJĘTNOŚCI I STOSOWANIE WIEDZY W PRAKTYCE.

\begin{tabular}{|c|c|}
\hline $\begin{array}{l}\text { 1. Wyszukiwanie informacji z różnych źródeł, ich } \\
\text { selekcja i analizowanie. }\end{array}$ & nie występuje \\
\hline $\begin{array}{l}\text { 2. Stosowanie w praktyce kluczowych pojęć związa- } \\
\text { nych z przedsiębiorczością. }\end{array}$ & nie występuje \\
\hline $\begin{array}{l}\text { 4. Odpowiedzialne gospodarowanie pieniędzmi, } \\
\text { analizowanie, ocenianie i świadome korzystanie } \\
\text { z usług finansowych oraz inwestowanie kapitału } \\
\text { z wykorzystaniem wiedzy na temat praw klienta } \\
\text { usług finansowych. }\end{array}$ & $\begin{array}{l}\text { [Uczeń] rozróżnia i porównuje formy inwe- } \\
\text { stowania i wynikające z nich ryzyko. }\end{array}$ \\
\hline $\begin{array}{l}\text { 5. Podejmowanie niezależnych, odpowiedzialnych } \\
\text { decyzji finansowych w odniesieniu do własnych } \\
\text { zasobów. }\end{array}$ & nie występuje \\
\hline $\begin{array}{l}\text { 6. Podnoszenie kompetencji osobistych i społecz- } \\
\text { nych niezbędnych na rynku pracy oraz wzmacnianie } \\
\text { motywacji do pracy. }\end{array}$ & nie występuje \\
\hline $\begin{array}{l}\text { 7. Analizowanie oferty rynku pracy, sporządzanie } \\
\text { dokumentów aplikacyjnych, dokonywanie autopre- } \\
\text { zentacji oraz korzystne prezentowanie się podczas } \\
\text { rozmowy kwalifikacyjnej. }\end{array}$ & $\begin{array}{l}\text { [Uczeń] opisuje mocne strony swojej oso- } \\
\text { bowości; analizuje dostępność rynku pracy } \\
\text { w odniesieniu do własnych kompetencji } \\
\text { i planów zawodowych. }\end{array}$ \\
\hline $\begin{array}{l}\text { 8. Rozróżnianie skutków wynikających z nawiązania } \\
\text { i rozwiązania stosunku pracy oraz wykonywania } \\
\text { czynności na podstawie umów cywilnoprawnych } \\
\text { i analizowanie przepisów Kodeksu pracy. }\end{array}$ & nie występuje \\
\hline $\begin{array}{l}\text { 9. Analizowanie otoczenia przedsiębiorstwa, w tym } \\
\text { rynku, na którym działa. }\end{array}$ & nie występuje \\
\hline $\begin{array}{l}\text { 10. Projektowanie działań w zakresie zakładania } \\
\text { własnego przedsiębiorstwa lub podejmowania } \\
\text { innych przedsięwzięć o charakterze społeczno-eko- } \\
\text { nomicznym. }\end{array}$ & nie występuje \\
\hline $\begin{array}{l}\text { 11. Przygotowanie do prowadzenia własnej działal- } \\
\text { ności gospodarczej. }\end{array}$ & nie występuje \\
\hline $\begin{array}{l}\text { 12. Efektywne uczestniczenie w pracy zespoło- } \\
\text { wej z wykorzystaniem umiejętności w zakresie } \\
\text { komunikacji interpersonalnej oraz wdrażanie zasad } \\
\text { skutecznego przywództwa w organizacji. }\end{array}$ & $\begin{array}{l}\text { [Uczeń] wykorzystuje formy komunikacji } \\
\text { werbalnej i niewerbalnej; podejmuje decy- } \\
\text { zje i ocenia ich skutki, zarówno pozytywne, } \\
\text { jak i negatywne. }\end{array}$ \\
\hline $\begin{array}{l}\text { 13. Rozpoznawanie działań etycznych i nieetycznych } \\
\text { w życiu gospodarczym oraz przejawów społecznej } \\
\text { odpowiedzialności biznesu. }\end{array}$ & $\begin{array}{l}\text { [Uczeń] wyjaśnia zasady etyczne w bizne- } \\
\text { sie i w relacjach pracownik-pracodawca, } \\
\text { potrafi ocenić zachowania pod względem } \\
\text { etycznym. }\end{array}$ \\
\hline
\end{tabular}




\section{Kształtowanie postaw.}

\begin{tabular}{|c|c|}
\hline $\begin{array}{l}\text { 1. Wykorzystanie zdobytej wiedzy ekonomicznej do } \\
\text { rozwijania własnej postawy przedsiębiorczej jako } \\
\text { jednego z podstawowych warunków aktywnego } \\
\text { uczestnictwa w życiu społeczno-gospodarczym, } \\
\text { w tym skutecznego wykonywania pracy najemnej } \\
\text { i prowadzenia własnej działalności gospodarczej. }\end{array}$ & nie występuje \\
\hline $\begin{array}{l}\text { 2. Korzystanie z szans pojawiających się na rynku, } \\
\text { podejmowanie inicjatywy, pomysłowość oraz } \\
\text { zdolność do pokonywania barier wewnętrznych } \\
\text { i zewnętrznych. }\end{array}$ & nie występuje \\
\hline $\begin{array}{l}\text { 3. Docenianie postaw przedsiębiorczych w życiu } \\
\text { codziennym, gotowość do czynnego uczestnictwa } \\
\text { w życiu społeczno-gospodarczym kraju oraz współ- } \\
\text { odpowiedzialność za jego rozwój. }\end{array}$ & nie występuje \\
\hline $\begin{array}{l}\text { 4. Docenianie roli przedsiębiorców budujących } \\
\text { w sposób odpowiedzialny konkurencyjną gospodarkę } \\
\text { oraz dostrzeganie znaczenia wolności gospodar- } \\
\text { czej i własności prywatnej jako filarów gospodarki } \\
\text { rynkowej. }\end{array}$ & nie występuje \\
\hline $\begin{array}{l}\text { 5. Przyjmowanie postaw patriotyzmu gospodarczego, } \\
\text { rozumianego jako odpowiedzialność konsumentów } \\
\text { i ludzi biznesu za dobrobyt gospodarczy i społeczny } \\
\text { kraju. }\end{array}$ & nie występuje \\
\hline $\begin{array}{l}\text { 6. Dostrzeganie konsekwencji działań nieetycz- } \\
\text { nych związanych z finansami, w tym obowiązkami } \\
\text { podatkowymi. }\end{array}$ & nie występuje \\
\hline $\begin{array}{l}\text { 7. Kształtowanie w sobie odpowiedzialnych postaw } \\
\text { jako przyszłych pracowników i pracodawców oraz } \\
\text { należytego wypełnienia obowiązków, a także } \\
\text { sprawiedliwego, opartego na prawości i dążeniu do } \\
\text { prawdy traktowania pracowników. }\end{array}$ & nie występuje \\
\hline $\begin{array}{l}\text { 8. Kształtowanie proaktywności, odpowiedzialności } \\
\text { za siebie i innych oraz umiejętnego godzenia własne- } \\
\text { go dobra z dobrem innych ludzi. }\end{array}$ & nie występuje \\
\hline $\begin{array}{l}\text { 9. Zainteresowanie prowadzeniem własnej dzia- } \\
\text { łalności gospodarczej oraz motywacja do ciągłego } \\
\text { samorozwoju i inwestowania w siebie. }\end{array}$ & nie występuje \\
\hline $\begin{array}{l}\text { 10. Kształtowanie postawy otwartości i szacunku do } \\
\text { innych osób oraz zdolności podejmowania dialogu } \\
\text { i współpracy. }\end{array}$ & nie występuje \\
\hline $\begin{array}{l}\text { 11. Przyjmowanie postaw etycznych, społecznej soli- } \\
\text { darności i odpowiedzialności w życiu gospodarczym. }\end{array}$ & nie występuje \\
\hline \multicolumn{2}{|c|}{$\begin{array}{l}\text { * tj. liceum, technikum i szkoły branżowej I stopnia (podstawa zapisana w postaci dwóch } \\
\text { rozporządzeń, jest w zakresie treści identyczna) } \\
{ }^{\star \star} \text { tj. liceum, technikum i zasadniczej szkoły zawodowej (podstawa dla szkoły zawodowej została } \\
\text { określona jako tożsama z tą do LO i technikum. }\end{array}$} \\
\hline
\end{tabular}


Jak widać szczególne miejsce w nowej podstawie programowej zajmuje nie tylko kształtowanie umiejętności, ale także i postaw, szczególnie tych związanych z samorozwojem, proaktywności, relacjami z innymi ludźmi, odpowiedzialności za siebie i innych, docenianiem działalności przedsiębiorców, a także postaw etycznych, solidarności i społecznej odpowiedzialności. Stanowi to nową jakość w podejściu do edukacji w zakresie przedsiębiorczości i nawiązuje do wcześniejszych postulatów w zakresie formułowania celów wychowawczych w edukacji w zakresie przedsiębiorczości (Rachwał 2005, 2017) i opinii B. Suchodolskiego (1990), że mimo fali krytyki i trudności jakie muszą pokonywać nauczyciele, nie powinni się oni wyrzekać troski o wychowanie uczniów. Wychowanie bowiem pozostaje jednym z głównych czynników kształtowania ludzi, a więc tym samym budowania przyszłości (Suchodolski 1990, Rachwał 2005).

\section{Działy treści nauczania w podstawie programowej dla szkół średnich}

Treści kształcenia w zakresie przedsiębiorczości zaproponowane w starej i nowej podstawie programowej wykazują pewne różnice, choć przy konstrukcji nowej podstawy programowej starano się korzystać z dotychczasowych dobrych doświadczeń. W efekcie tego nowa podstawa zawiera zapisy wymagań szczegółowych, które nawiązują wyraźnie do niektórych wcześniejszych. Układ treści jest jednak inny.

W podstawie programowej z 2012 roku wyróżniono sześć działów, zgodnie z rozporządzeniem wymagania szczegółowe podzielone zostały na sześć działów:

$\rightarrow$ Człowiek przedsiębiorczy,

$\rightarrow$ Rynek - cechy i funkcje,

$\rightarrow$ Instytucje rynkowe,

$\rightarrow$ Państwo, gospodarka,

$\rightarrow$ Przedsiębiorstwo,

$\rightarrow$ Rynek pracy.

Natomiast w nowej podstawie programowej wymagania szczegółowe, dotyczące treści kształcenia, podzielono na cztery działy (zapisując oprócz ich hasłowych nazw także treści kształcenia: 
$\rightarrow$ Gospodarka rynkowa: przedsiębiorczość w gospodarce rynkowej, gospodarka nakazowo-rozdzielcza (centralnie planowana) i rynkowa, rodzaje rynków, podmioty gospodarki rynkowej, struktury rynkowe, mechanizm rynkowy, fazy cyklu koniunkturalnego, rola państwa w gospodarce, konsument na rynku.

$\rightarrow$ Rynek finansowy: pieniądz i jego obieg, instytucje rynku finansowego, formy inwestowania, bank centralny i polityka pieniężna, bankowość komercyjna i spółdzielcza, podatki, ubezpieczenia, umowy bankowe i ubezpieczeniowe, ochrona klienta usług finansowych, etyka w finansach

$\rightarrow$ Rynek pracy: mierniki i wskaźniki, popyt i podaż na rynku pracy, kariera zawodowa, poszukiwanie pracy, rozmowa kwalifikacyjna, formy zatrudnienia, systemy płac, prawa i obowiązki pracownika i pracodawcy, bhp i organizacja pracy, Państwowa Inspekcja Pracy, związki zawodowe, etyka w pracy.

$\rightarrow$ Przedsiębiorstwo: klasyfikacje przedsiębiorstw, biznesplan, otoczenie przedsiębiorstwa, formy organizacyjno-prawne, procedury rejestracji i likwidacji, źródła finansowania działalności, analiza rynku, zarządzanie przedsiębiorstwem, praca zespołowa, marketing, wynik finansowy, formy opodatkowania, księgowość, negocjacje, etyka w biznesie i społeczna odpowiedzialność przedsiębiorstw, funkcjonowanie przedsiębiorstwa.

Analiza wymagań szczegółowych wskazuje, że w nowej podstawie programowej położono nacisk na: identyfikację zjawisk i dostrzeganie prawidłowości, dyskusję, poruszanie szerokich tematów (w tym również trudnych i kontrowersyjnych), analizowanie i interpretowanie zebranych informacji, ocenianie i dostrzegania różnych aspektów analizowanych zjawisk ekonomicznych, kształtowanie człowieka myślącego i zdolnego do merytorycznej dyskusji (który nie poddaje się manipulacyjnym przekazom z mediów i ideologicznym interpretacjom, fake-newsom itp.), umiejętność czytania ze zrozumieniem (aktów prawnych, umów, ogólnych warunków ubezpieczenia itp.), a przede wszystkim na kształtowanie postaw, szczególnie odpowiedzialności, uczciwości, otwartości i szacunku (Rachwał i in. 2018). Zauważa się też zmianę polegającą na przesunięciu nacisku z wyposażenia uczniów w wiedzę ekonomiczną na rzecz kształtowania umiejętności związanych z finansami, biznesem i zachowaniami niezbędnymi na rynku pracy. 


\section{Nowe innowacyjne treści w podstawie programowej dla szkól średnich}

Analiza nowej podstawy programowej do podstaw przedsiębiorczości pozwoliła ocenić jej zapisy pod kątem nowych innowacyjnych treści i umiejętności, które zostały wprowadzone do nowej podstawy programowej w ramach reformy edukacji w Polsce. Jednocześnie dokonano weryfikacji treści nauczania - wymagań szczegółowych, które sprzyjają przygotowaniu ucznia do nowych wyzwań, które ze sobą niesie XXI w., głównie tych związanych z budową gospodarki opartej na wiedzy i rozwojem cywilizacji informacyjnej.

W podstawie programowej pojawiło się szereg nowych zapisów, które można określić jako innowacyjne. Najwięcej treści związanym z nowoczesnymi zagadnieniami znajduje się w rozdziale czwartym nt. przedsiębiorstwa. Po pierwsze, w zapisach podstawy, podkreślane jest szczególnie to, czego nie było $w$ dotychczasowych podstawach programowych, a mianowicie duże znaczenie innowacyjności i kreatywności. Zapisy dotyczące kreatywności dotyczą działań promocyjnych, które wedle podstawy powinny być projektowane kreatywnie (4.13), zaplanowane i pełne refleksji. Jednocześnie kreatywność, ale i innowacyjność zdaniem autorów podstawy powinna być też dostrzegana przez uczniów w ich życiu osobistym, w rozwoju społeczno-gospodarczym w skali lokalnej, regionalnej, krajowej i globalnej (1.3).

Zapisy związane z innowacyjnością odnoszą się także do planowanej $w$ ramach zajęć $z$ podstaw przedsiębiorczości własnej działalności gospodarczej lub przedsięwzięcia społecznego, które uczniowie powinni oceniać pod względem innowacyjności (4.3). Innym zapisem, który odwołuje do uwzględniania innowacyjności działalności przedsiębiorstwa jest ostatnie z wymagań szczegółowych, które odnosi się ćwiczeń terenowych lub spotkania z przedsiębiorcą, podczas których uczeń zobowiązany jest do analizy procesu funkcjonowania przedsiębiorstwa lub jego prowadzenia m.in. w odniesieniu do podejmowanych przez nie działaniach innowacyjnych (4.23).

Ważne zapisy dotyczące nowych zagadnień dotyczą także współczesnych form finansowania działalności gospodarczej, nie poruszanych w poprzedniej podstawie programowej. W ósmym podpunkcie dotyczącym przedsiębiorstwa (4.8) wskazano, że uczeń powinien „znajdować możliwości finansowania działalności gospodarczej lub projektowanego przedsięwzięcia (w tym ze środków instytucji finansowych, urzędów 
pracy, funduszy unijnych i venture capital, „aniołów biznesu”) oraz określać funkcje inkubatorów przedsiębiorczości w powstawaniu i rozwoju małych firm, w tym start-upów". To odwołanie do form finansowania, ale i sposobów zakładania najnowocześniejszych przedsiębiorstw, które w Polsce bardzo szybko zyskują na znaczeniu i zdaniem A. Skali (2018) stanowią także duże wyzwanie dla systemu edukacji. Przykładem może być działalność podejmowana w Krakowskim Parku Technologicznym, w którym start-upom zapewniana jest szeroka pomoc, w tym najlepszym firmom proponowane są oferty "aniołów biznesu", którzy mogą zaoferować dostęp do dużego kapitałem międzynarodowego

Odwołanie do start-upów jest także na początku czwartego rozdziału, w punkcie pierwszym (4.1), który zobowiązuje uczniów do „klasyfikacji przedsiębiorstw według kryteriów rodzaju prowadzonej działalności, wielkości i formy własności oraz charakteryzuje innowacyjne modele biznesu, w tym start-upy". Zatem zarówno zapisy dotyczące wiedzy, jak i umiejętności odnoszą się do zupełnie nowych zagadnień, które we współczesnej gospodarcze, choć nowe, to znalazły już swoje stałe miejsce.

W podstawie programowej znajdują się także zapisy, których realizacja pozwoli młodemu człowiekowi przygotować się do funkcjonowania we współczesnym świecie. Szczególnie ważne wydają się zapisane efekty kształcenia, które wymagają od ucznia skorelowania poznanej wiedzy i umiejętności z własnym życiem. Już w pierwszym wymaganiu szczegółowym w rozdziale pierwszym znajdujemy zapis: „uczeń: identyfikuje cechy człowieka o postawie przedsiębiorczej, rozpoznaje je u siebie oraz określa związek zachowania się osoby przedsiębiorczej z szansami, jakie stwarza gospodarka rynkowa (1.1)". Podobnie w rozdziale dotyczącym rynku pracy znajdujemy odniesienie do tych ważnych umiejętności: „rozpoznaje motywy aktywności zawodowej człowieka oraz analizuje szanse i możliwości rozwoju własnej kariery zawodowej, dostrzegając rolę procesu uczenia się przez całe życie" (3.3).

Podkreślana jest także umiejętność samodzielnego myślenia, która jest także ważna w natłoku różnych informacji trafiających do człowieka różnymi kanałami przekazu, np. „uczeń: ocenia wady i zalety poszczególnych form opodatkowania indywidualnej działalności gospodarczej w zakresie podatku dochodowego (...)" (4.15). Ponadto uwydatniona jest potrzeba uczenia się poprzez bliskie uczniowi przykłady, np. „wyszukuje i analizuje informacje o sukcesach polskich przedsiębiorstw, w tym ze 
swojego regionu, na rynku krajowym i międzynarodowym, osiąganych zgodnie z prawem i etyką biznesu" (4.22), gdyż takie przykłady wydają się dla ucznia bliższe i możliwe do głębszego poznania i zrozumienia ponieważ pochodzą z najbliższego otoczenia.

\section{Podsumowanie}

Należy stwierdzić, że nowa podstawa programowa podstaw przedsiębiorczości do szkół średnich stanowi próbę odpowiedzi na współczesne wyzwania cywilizacyjne i powinna przyczynić się do lepszego przygotowania ich do realizacji celów w życiu osobistym i zawodowym, w tym wykonywania pracy najemnej i samozatrudnienia. Położone większy nacisk na cele ogólne w zakresie rozwijania umiejętności i kształtowania postaw. Rozszerzone zostały w niej treści kształcenia związane z pracą i funkcjonowaniem przedsiębiorstwa (w tym zakładaniem swojego biznesu), dla których podbudową jest wcześniej realizowana problematyka ekonomiczna i finansowa. Nowa podstawa programowa wprowadza także szereg zagadnień, które dotychczas nie występowały $w$ tym fundamentalnym dokumencie. Wprowadzenie innowacyjnych treści kształcenia w zakresie wiedzy i umiejętności, a także postaw należy uznać za konieczność. Podstawa programowa powinna wrowadzać $w$ ten sposób zagadnienia nowe, które są konieczne, aby przygotować ucznia do wyzwań współczesnego świata. Takie podejście znalazło swoje odzwierciedlenie w zapisach podstawy. Kluczową rolę w jej realizacji odgrywa jednak nauczyciel, dlatego problematyka ta wymaga dalszych badań nad wdrażaniem zapisów podstawy w praktyce szkolnej. Czas pokaże w jakim stopniu jest ona wdrażana. 


\section{Bibliografia}

$\rightarrow$ Andrzejczyk, A. (2016), Metody badań edukacji przedsiębiorczej [w:] „Przedsiębiorczość - Edukacja", nr 12, s. 352-363.

$\rightarrow$ Bartoń, M., 2005, Przedsiębiorczość jako przedmiot matury 2008 [w:] „Przedsiębiorczość - Edukacja", nr 1, s. 255-258.

$\rightarrow$ Borowiec, M., Rachwał, T. (2011), Kształtowanie postaw przedsiębiorczych na lekcjach geografii wyzwaniem edukacyjnym w procesach globalizacji [w:] „Przedsiębiorczość - Edukacja”, nr 7, s. 321-332.

$\rightarrow$ Borowiec-Gabryś, M., Kilar, W., Rachwał, T. (2018), Przedsiębiorczość jako kompetencja przyszłości [w:] S. Kwiatkowski (red.), Kompetencje przyszłości, Warszawa: FRSE, s. 68-89.

$\rightarrow$ Brzozowski, T., (2013), Status przedsiębiorczości w warunkach kryzysu edukacji [w:] „Przedsiębiorczość - Edukacja”, nr 9, s. 258-272.

$\rightarrow$ Czechowski, J. (2014), Przedsiębiorczy nauczyciel jako skuteczny wychowawca [w:] „Horyzonty Wychowania”, nr 13(26), s. 145-163.

$\rightarrow$ Gaweł, A. (2014), Gry strategiczne w edukacji przedsiębiorczej [w:] „Horyzonty Wychowania", nr 13(26), s. 303-325.

$\rightarrow$ Górz, B., Rachwał T. (2006), Uwagi do projektu zmiany podstawy programowej podstaw przedsiębiorczości (zrealizowanej przez Instytut Spraw Publicznych na zlecenie Ministerstwa Edukacji Narodowej) [w:] „Horyzonty Wychowania”, nr 2, s. 226-235.

$\rightarrow$ Kalita, B. (2014), Przedsiębiorczość jako kompetencja kluczowa w procesie uczenia się przez całe życie [w:] „Zeszyty Naukowe Politechniki Śląskiej. Organizacja i Zarządzanie", nr 72, s. 51-64.

$\rightarrow$ Kawecki, Z. (2005), Ranga przedmiotu podstawy przedsiębiorczości w edukacji szkolnej [w:] „Przedsiębiorczość - Edukacja”, nr 1, s. 203-206.

$\rightarrow$ Kilar, W., Kurek, S., Rachwał, T., Semczuk, M., Świętek, A. (2016), Kształtowanie postaw przedsiębiorczych z uwzględnieniem zasad ekorozwoju wśród uczniów 
z wykorzystaniem gry PowerPlayer wypracowanej w ramach projektu SUSEN [w:] „Przedsiębiorczość - Edukacja”, nr 12, s, 444-456.

$\rightarrow$ Kompetencje kluczowe. Realizacja koncepcji na poziomie szkolnictwa obowiq̨zkowego (2005), Warszawa: Eurydice, Fundacja Rozwoju Systemu Edukacji.

$\rightarrow$ Kulikowska, M., Krasnodębska, B. (2007), Techniki multimedialne w nauczaniu podstaw przedsiębiorczości [w:] „Przedsiębiorczość - Edukacja”, nr 3, s. 308$-316$.

$\rightarrow \quad$ Łazowska, E. (2005), Metodyka nauczania podstaw przedsiębiorczości i podstaw ekonomii [w:] „Przedsiębiorczość - Edukacja”, nr 1, Kraków, s. 251-254.

$\rightarrow$ Osuch, E., Osuch W. (2006), Przedmiot podstawy przedsiębiorczości w opinii uczniów i rodziców na przykładzie wybranych krakowskich szkół [w:] „Przedsiębiorczość - Edukacja", nr 1, s. 195-202.

$\rightarrow$ Osuch, W. (2012), Podstawy przedsiębiorczości w opinii uczniów krakowskich liceów-szanse i oczekiwania. [w:] „Przedsiębiorczość-Edukacja”, nr 8, 37-47.

$\rightarrow$ Piróg, D. (2015), Kompetencje z zakresu przedsiębiorczości: rozważania teoretyczne i ich ilustracje w obszarze szkolnictwa wyższego [w:] „Przedsiębiorczość - Edukacja", nr 11, 364-376.

$\rightarrow$ Rachwał, T. (2017), Entrepreneurship in School in the Conditions of the Education System Reform in Poland - a Voice in the Discussion on the Directions of Change [w:] „Przedsiębiorczość -Edukacja”, nr 13, s. 330-339.

$\rightarrow$ Rachwał, T. (2006), Kształtowanie postaw przedsiębiorczych w edukacji szkolnej [w:] B. Muchacka (red.), Szkoła w nauce i praktyce edukacyjnej, t.II, Kraków: Oficyna Wydawnicza "Impuls", Akademia Pedagogiczna w Krakowie, s.427-434.

$\rightarrow$ Rachwał, T., Kurek, S., Boguś, M. (2016), Entrepreneurship Education at Secondary Level in Transition Economies: A Case of Poland [w:] "Entrepreneurial Business and Economics Review", 4(1), s. 61-81.

$\rightarrow$ Rachwał, T. (2004), Cele i treści kształcenia przedsiębiorczości w szkołach ponadgimnazjalnych. [w:] J. Brdulak, M. Kulikowski (red.), Przedsiębiorczość stymulatorem rozwoju gospodarczego, Warszawa: Instytut Wiedzy, s. 263-270.

$\rightarrow$ Rachwał, T. (2005), Kształtowanie postaw u uczniów na lekcjach przedsiębiorczości [w:] „Przedsiębiorczość - Edukacja”, nr 1, s. 137-144.

$\rightarrow$ Rachwał, T. (2009), Ocena projektu zmian podstawy programowej podstaw przedsiębiorczości (przedstawionej przez MEN w 2008 r. w ramach reformy systemu edukacji) [w:] „Przedsiębiorczość - Edukacja”, nr 5, s. 349-372.

$\rightarrow$ Rachwał, T., Kilar, W., Kawecki, Z., Wróbel, P. (2018), Edukacja w zakresie przedsiębiorczości w wychowaniu przedszkolnym, szkole podstawowej i szkołach średnich w świetle nowej podstawy programowej [w:] „Przedsiębiorczość - Edukacja", nr 14, s. 389-424. 
$\rightarrow$ Rachwał, T., Kudełko, J., Tracz, M., Wach, K., Kilar, W. (2008), Projekt podstawy programowej podstaw przedsiębiorczości w zakresie rozszerzonym dla liceum ogólnokształcącego, liceum profilowanego i technikum [w:] „Przedsiębiorczość - Edukacja", nr 4, s. 322-334.

$\rightarrow$ Rozporzq̨dzenie Ministra Edukacji Narodowej z dnia 26 lipca 2018 r. zmieniajqce rozporządzenie w sprawie podstawy programowej wychowania przedszkolnego oraz podstawy programowej kształcenia ogólnego dla szkoły podstawowej, w tym dla uczniów z niepełnosprawnościq intelektualnq w stopniu umiarkowanym lub znacznym, kształcenia ogólnego dla branżowej szkoły I stopnia, kształcenia ogólnego dla szkoły specjalnej przysposabiajq̨cej do pracy oraz kształcenia ogólnego dla szkoły policealnej, 2018b (Dz.U. 2018, poz. 1679).

$\rightarrow$ Rozporządzenie Ministra Edukacji Narodowej z dnia 27 sierpnia 2012 r. w sprawie podstawy programowej wychowania przedszkolnego oraz kształcenia ogólnego w poszczególnych typach szkół (Dz.U. 2012, poz. 977).

$\rightarrow$ Rozporządzenie Ministra Edukacji Narodowej z dnia 28 marca 2017 r. w sprawie ramowych planów nauczania dla publicznych szkół (Dz.U. 2017, poz. 703).

$\rightarrow$ Rozporzqqdzenie Ministra Edukacji Narodowej z dnia 30 stycznia 2018 r. w sprawie podstawy programowej kształcenia ogólnego dla liceum ogólnokształcącego, technikum oraz branżowej szkoły Il stopnia, 2018a (Dz.U. 2018, poz. 467).

$\rightarrow$ Skala, A. (2018), Startupy. Wyzwanie dla zarzq̨dzania i edukacji przedsiębiorczości, Kraków-Legionowo: edu-Libri.

$\rightarrow$ Sowislok, K. (2012), Przedsiębiorczość w szkole ponadgimnazjalnej na przykładzie II Liceum Ogólnokształcq̨cego w Zabrzu [w:] „Przedsiębiorczość - Edukacja", nr 8, 57-63.

$\rightarrow$ Suchodolski, B., 1990, Wychowanie mimo wszystko, Warszawa: WSiP.

$\rightarrow$ Szkurłat E., Hibszer A., Piotrowska l., Rachwał T. (2018), Podstawa programowa geografii źródłem nauczycielskich wyzwań [w:] Adam Hibszer, Elżbieta Szkurłat (red.), Nauczyciel geografii wobec wyzwań reformowanej szkoły, Seria: Prace Komisji Edukacji Geograficznej Polskiego Towarzystwa Geograficznego, t. 8, Sosnowiec: Komisja Edukacji Geograficznej PTG, s. 13-31.

$\rightarrow$ Śrutowska, D., 2006, Wykorzystanie multimediów w nauczaniu przedsiębiorczości [w:] „Przedsiębiorczość - Edukacja”, nr 2, s. 264-278.

$\rightarrow$ Tracz, M. (2005), O niektórych kryteriach doboru treści nauczania do podstawy programowej i programu nauczania z podstaw przedsiębiorczości [w:] „Przedsiębiorczość - Edukacja", nr 1, s. 207-21.

$\rightarrow$ Tracz, M. (2006), Rola i znaczenie podstaw przedsiębiorczości w kształceniu ogólnym [w:] „Przedsiębiorczość - Edukacja”, nr 2, s. 222-22. 
$\rightarrow$ Tracz, M. (2015), Przedmiot podstawy przedsiębiorczości w opinii uczniów i nauczycieli - studium porównawcze [w:] „Przedsiębiorczość - Edukacja”, nr 11, s. 391-400.

$\rightarrow$ Tracz, M., Rachwał, T. (2007), Przedmiot podstawy przedsiębiorczości - założenia realizacji a przygotowanie nauczycieli [w:] „Przedsiębiorczość - Edukacja”, nr 3, s. 286-296.

$\rightarrow$ Tracz, M., Rachwał, T. (2008), Metody nauczania i środki dydaktyczne stosowane przez nauczycieli podstaw przedsiębiorczości - wyniki badań [w:] „Przedsiębiorczość - Edukacja", nr 4, s. 335-340.

$\rightarrow$ Wach, K. (2012), Kształtowanie postaw przedsiębiorczych w programach nauczania. Stan obecny i proponowane kierunki zmian [w:] P. Wachowiak, M. Dąbrowski, B. Majewski (red.), Kształtowanie postaw przedsiębiorczych a edukacja ekonomiczna, Warszawa: Fundacja Promocji i Akredytacji Kierunków Ekonomicznych, s. 120-127

$\rightarrow$ Wach, K. (2013), Edukacja na rzecz przedsiębiorczości wobec współczesnych wyzwań cywilizacyjno-gospodarczych [w:] „Przedsiębiorczość - Edukacja”, nr 9, s. 246-257.

$\rightarrow$ Wach, K. (2014), Edukacja dla przedsiębiorczości: pomiędzy przedsiębiorczq pedagogikq a edukacją ekonomicznq i biznesową [w:] „Horyzonty Wychowania", nr 13(28), s. 11-31.

$\rightarrow$ Wach, K. (2016), Edukacja przedsiębiorcza: analiza bibliometryczna polskiego piśmiennictwa. Horyzonty Wychowania, 15(34), s. 11-26.

$\rightarrow$ Ziółkowska-Weiss, K. (2014), Problematyka podstaw przedsiębiorczości w opinii uczniów szkoły ponadgimnazjalnej. Przydatność w życiu czy konieczność nauki? [w:] „Przedsiębiorczość - Edukacja”, nr 10, s. 366-377.

$\rightarrow$ Ziółkowska-Weiss, K. (2016), Ocena nauczania podstaw przedsiębiorczości przez uczniów liceum ogólnokształcq̨cego [w:] „Przedsiębiorczość - Edukacja”, nr 12, s. 457-47.

$\rightarrow$ Żur, A. (2014), Exploring the Role of Inspiration in Entrepreneurship Education [w:] „Horyzonty Wychowania”, nr 13(26), s. 179-194. 


\section{Przedsiębiorczość w kształceniu studentów, dorosłych i seniorów}

Grażyna Nowaczyk, Anna Sobczak

Celem artykułu jest omówienie przedsiębiorczości jako domeny badawczej, uporządkowanie terminologiczne związane z tą domeną, a także ukazanie głównych wyników badań prowadzonych w tym zakresie. Przedstawiono też wyniki badań dotyczących postaw przedsiębiorczych studentów. W obliczu starzenia się społeczeństw zwrócono uwagę na przedsiębiorczość seniorów, która staje się jednym z ważniejszych obszarów badań w krajach rozwiniętych.

\section{Słowa kluczowe:}

\section{przedsiębiorczość}

kształcenie

szkoła wyższa

przedsiębiorczość seniorów

przedsiębiorczość studentów 


\section{Entrepreneurship in the education of university students, adults and seniors}

Grażyna Nowaczyk, Anna Sobczak

This paper aims to discuss the entrepreneurship as the research domain, as well as to organize the terminology associated with that domain, and to present the main findings of research conducted in this area. The article elaborates on the outcomes of a survey concerning student entrepreneurial attitudes and held on a sample of students of economic studies. Senior entrepreneurship is becoming one of the most important areas of research in developed countries, especially in the face of population aging in these countries. Prior studies have shown that older people in their third age are less inclined to take up economic activities and have lower entrepreneurial intentions than younger people in their prime age. 


\section{Wstęp}

Przedsiębiorczość, uznawana za jedną z kluczowych kompetencji, nie jest jednoznacznie definiowana. Stąd jej nauczanie może obejmować swoim zakresem kształtowanie różnorodnych umiejętności. Często pojęcie przedsiębiorczości odnosi się do cech osobowości człowieka, procesu zakładania działalności gospodarczej oraz umiejętności wykorzystywania szans w otoczeniu i podejmowania działań innowacyjnych (Borowiec-Gabryś, Kilar, Rachwał 2018). Kształcenie przedsiębiorczości na poziomie wyższym dotyczyć może wszystkich trzech aspektów. Istnieje jednak potrzeba kształtowania postaw przedsiębiorczych, a w szczególności umiejętności zakładania działalności gospodarczej i jej rozwijania. Jak wynika ze Światowego Raportu Amway o Przedsiębiorczości AGER 2018, przygotowanego przez Instytut GfK pod patronatem Uniwersytetu Technicznego w Monachium ${ }^{1}$, skłonność Polaków do zakładania przedsiębiorstw zmniejsza się w ostatnich latach. W najnowszym badaniu chęć założenia własnej działalności deklarowało 27 proc. badanych Polaków, podczas gdy w 2016 r. było ich 32 proc. Z danych GUS wynika, że spośród utworzonych w 2017 r. podmiotów niefinansowych prowadzących działalność gospodarczą w 2018 r. działalność tę kontynuowały tylko dwa przedsiębiorstwa na trzy². W UE wskaźnik ducha przedsiębiorczości był wyższy niż w Polsce i wynosił 42 proc., a we wszystkich badanych państwach -47 proc. $^{3}$.

Możliwości prowadzenia analizy w tym zakresie są jednak ograniczone z uwagi na duże zróżnicowanie charakteru realizowanych kierunków studiów, kształtowanych kompetencji, wykorzystywanych metod kształcenia, a także dodatkowych aktywności sprzyjających rozwojowi przedsiębiorczości. Uczenie przedsiębiorczości na studiach wyższych powinno być dostosowane do poziomu, profilu i kierunku kształcenia. Na kierunkach ekonomicznych nauczanie przedsiębiorczości koncentruje się na budowaniu kompetencji związanych z zakładaniem

1. Badaniami objęto reprezentatywną próbę 50 tys. osób z 44 państw świata, w tym ponad 1 tys. Polaków.

2. Przedsiębiorstwa niefinansowe powstałe w 2017 r., stat.gov.pl/obszary-tematyczne/ podmioty-gospodarcze-wyniki-finansowe/przedsiebiorstwa-niefinansowe/przedsiebiorstwaniefinansowe-powstale-w-2017-roku,25,1.html (dostęp: 3.12.2018).

3. Światowy Raport Amway o Przedsiębiorczości AGER 2018, networkmagazyn.pl/swiatowyraport-amway-o-przedsiebiorczosci-ager-2018 (dostęp: 3.12.2018). 
działalności gospodarczej, ponieważ ze swej natury kierunki te kształtują różnego typu umiejętności biznesowe, natomiast na kierunkach technicznych kompetencje przedsiębiorcze mogą w większym stopniu obejmować umiejętności kreowania i wykorzystania pomysłów technologicznych, a na artystycznych - wykorzystania kreatywności do prowadzenia działalności na własny rachunek ${ }^{4}$.

\section{Programy studiów}

Znaczenie kształtowania kompetencji z zakresu przedsiębiorczości na studiach można rozpatrywać w kontekście analizy programów studiów. W 2016 r. przeprowadzono analizę programów studiów w czterech krajach z Grupy Wyszehradzkiej: w Czechach, Polsce, na Słowacji i Węgrzech. Analizie poddano łącznie 188 programów studiów (Egerova 2016). Badano programy studiów zarówno na kierunkach ekonomicznych (głównie ekonomia i zarządzanie), jak i na innych (technicznych, artystycznych, humanistycznych), na pierwszym oraz drugim stopniu. Badano po 50 proc. kierunków ekonomicznych i nieekonomicznych w każdym kraju. Wyniki analizy pokazują zakres nastawienia uczelni na kształtowanie postaw przedsiębiorczych, w szczególności w rozumieniu przygotowania do podejmowania i prowadzenia własnej działalności gospodarczej. Z danych zawartych w tabeli 1 wynika, że około 40 proc. kierunków ma w programach studiów przedmiot (co najmniej jeden), który bezpośrednio dotyczy przedsiębiorczości. Są to przedmioty przygotowujące do otwarcia własnej działalności gospodarczej i na dodatek takie, które w nazwie mają słowo „przedsiębiorczość". W Polsce udział programów z co najmniej jednym przedmiotem bezpośrednio związanym z przedsiębiorczością jest najniższy i wynosi 31 proc. Poza tym na badanych kierunkach studiów realizowane są też przedmioty, które można powiązać z przedsiębiorczością, ponieważ dotyczą zagadnień związanych z funkcjonowaniem firmy. Są to np.: zarządzanie, marketing, rachunkowość, finanse, biznesplan, negocjacje - występują one kilkakrotnie częściej. Łącznie przedmioty bezpośrednio i pośrednio związane z przedsiębiorczością znajdowały się w programach studiów 93 proc. badanych kierunków.

4. Przedsiębiorczość w szkolnictwie wyższym, szczególnie na studiach nieekonomicznych, streszczenie Sprawozdania końcowego grupy ekspertów, Komisja Europejska, 2008, ec.europa.eu/docsroom/documents/8969/attachments/1/translations/pl/.../native, 3.12.2018. 
Tabela 1. Kierunki studiów z co najmniej jednym przedmiotem bezpośrednio związanym z przedsiębiorczością i bez przedmiotów związanych bezpośrednio i pośrednio z przedsiębiorczością

\begin{tabular}{l|c|c|c}
\multicolumn{1}{c|}{ KRAJ } & $\begin{array}{c}\text { LICZBA } \\
\text { ANALIZOWANYCH } \\
\text { KIERUNKów } \\
\text { STUDIÓW }\end{array}$ & $\begin{array}{c}\text { PROCENT KIERUNKÓW } \\
\text { Z PRZEDMIOTEM/-AMI } \\
\text { BEZPOŚREDNIO ZWIAZZANYM/-MI } \\
\text { Z PRZEDSIĘBIORCZOŚCIA }\end{array}$ & $\begin{array}{c}\text { PROCENT KIERUNKÓW } \\
\text { BEZ PRZEDMIOTÓW } \\
\text { ZWIAZZANYCH } \\
\text { Z PRZEDSIĘBIORCZOŚCIĄ }\end{array}$ \\
\hline Czechy & 59 & 39 & 9 \\
\hline Węgry & 36 & 44 & 6 \\
\hline Polska & 42 & 31 & 7 \\
\hline Słowacja & 51 & 43 & 6 \\
\hline Ogółem & 188 & 39 & 7
\end{tabular}

Źródło: Na podstawie Entrepreneurship education. Opportunities and Challenges for Universities in Visegrad Countries, ed. by D. Egerova, NAVA, Pilzno 2016, tab. 4.3 i 4.5, s. 58-59.

W Polsce na badanych kierunkach studiów było łącznie 13 przedmiotów bezpośrednio związanych z kierunkiem studiów i 162 pozostałe, które są przydatne w nauczaniu sposobów funkcjonowania przedsiębiorstw. Przedmioty bezpośrednio związane z przedsiębiorczością, mające w nazwie słowo "przedsiębiorczość", obejmowały swoim zakresem m.in. wiedzę z zakresu regulacji prawnych związanych z prowadzeniem działalności gospodarczej, źródeł wspierania przedsiębiorczości (inkubatory, instytucje oferujące dotacje i pożyczki), kształtowania umiejętności rejestrowania działalności gospodarczej, tworzenia biznesplanu przedsięwzięcia z uwzględnieniem ryzyka prowadzenia działalności gospodarczej czy analizy i oceny pomysłów biznesowych (Nowiński, Nowaczyk, Sobczak, Tomczyk, Fabiś 2016).

$Z$ kolei analiza programów studiów pierwszego i drugiego stopnia dotycząca 15 kierunków ekonomicznych realizowanych na pięciu uczelniach w Polsce w zakresie ekonomii, finansów i rachunkowości oraz zarządzania wykazała, że na tych kierunkach przedmioty bezpośrednio i pośrednio związane z przedsiębiorczością stanowiły prawie jedną piątą ogólnej liczby przedmiotów realizowanych na kierunku i umożliwiały zdobycie 16 proc. punktów ECTS. Dodać jednak należy, że tylko na zarządzaniu realizowane były przedmioty bezpośrednio związane z przedsiębiorczością, na których omawiano takie zagadnienia jak np. zalety i wady prowadzenia własnego biznesu, osobowość przed- 
siębiorcy - cechy i predyspozycje przedsiębiorcy, tworzenie pomysłów na własną działalność, zakładanie działalności gospodarczej, formy organizacyjno-prawne przedsiębiorstw (Nowaczyk, Sobczak 2016).

Analizując z kolei materiały dostępne na stronie Szkoły Głównej Handlowej ${ }^{5}$, można zauważyć, że student rozpoczynający naukę $w$ roku akademickim 2018/2019, niezależnie od kierunku na studiach pierwszego i drugiego stopnia, będzie znał formy rozwoju indywidualnej przedsiębiorczości, potrafił wykorzystywać posiadaną wiedzę w działalności zawodowej, w tym w prowadzeniu firmy na własny rachunek, i będzie gotów do myślenia i działania w sposób przedsiębiorczy. Kompetencje te są kształtowane w trakcie realizacji różnych przedmiotów. Na prowadzonych w SGH w języku polskim sześciu kierunkach studiów pierwszego stopnia tylko na zarządzaniu zaplanowano przedmiot mający w nazwie "przedsiębiorczość", co w dotychczasowym ujęciu oznacza, że jest bezpośrednio związany z przedsiębiorczością, natomiast na 13 kierunkach studiów drugiego stopnia taki przedmiot wystąpił na czterech kierunkach. Na wszystkich kierunkach studiów na tej uczelni realizowane są jednak (niekiedy nawet $w$ dużej liczbie) także przedmioty związane z przedsiębiorczością, kształtujące różne umiejętności z zakresu funkcjonowania przedsiębiorstwa i jego rozwoju. Jest ich najwięcej na zarządzaniu.

Poza przedmiotami kształcącymi kompetencje z zakresu przedsiębiorczości pojawiają się na polskich uczelniach kierunki i specjalności z tego zakresu, na których bardziej kompleksowo podchodzi się do kształtowania omawianych w tym artykule kompetencji. Kierunek przedsiębiorczość jest prowadzony np. na Wydziale Prawa i Administracji Uniwersytetu Śląskiego w Katowicach. Z kolei przykładem specjalności z tego zakresu jest przedsiębiorczość w małej i średniej firmie, wykładana na studiach drugiego stopnia kierunku zarządzanie na Wydziale Zarządzania Uniwersytetu Ekonomicznego w Poznaniu (Nowiński, Nowaczyk, Sobczak, Tomczyk, Fabiś 2016).

\section{Nauczanie przedsiębiorczości w opinii studentów studiów stacjonarnych i niestacjonarnych}

Na podstawie przeprowadzonych badań fokusowych (lata 2016 i 2018) wśród studentów kierunków ekonomicznych (zarządzania, ekonomii

5. Strona internetowa SGH: dziekanat.sgh.waw.pl/informatory/informator_2018_opis_sl_sm.pdf (dostęp: 27.11.2018). 
i logistyki) zdiagnozowano wpływ nauczania przedsiębiorczości studentów na kształcenie postaw przedsiębiorczych i wspieranie inicjatyw przedsiębiorczych podejmowanych na poziomie regionalnym, krajowym czy globalnym przez studentów. Zebrane opinie i sugestie pozwoliły na wskazanie zmian, które powinny podejmować uczelnie, by lepiej przygotować młodych ludzi do przedsiębiorczości.

Studenci kierunków ekonomicznych podczas badań fokusowych podkreślali, że niezbędna jest nauka przedsiębiorczości, szczególnie na studiach ekonomicznych, ponieważ jest to grupa studentów, która w przyszłości ma zajmować się szeroko rozumianym biznesem. Wszystkie badane grupy wskazywały, że nauka przedsiębiorczości, pomimo że jest realizowana od szkoły gimnazjalnej, skupia się na wiedzy teoretycznej, a nie na wykształcaniu stosownej postawy wśród młodych ludzi. Zdaniem studentów przedsiębiorczość jako przedmiot albo nie funkcjonuje w planie studiów, albo jego formuła sprowadza się do kilku zajęć, które niewiele wnoszą do kształcenia. Studenci, którzy mieli taki przedmiot, nie wskazywali, aby zasadniczo wpłynął on na ich postawę przedsiębiorczą. Na studiach od roku 2016 (kiedy przeprowadzono pierwsze badanie) do 2018 r. (kiedy powtórzono badanie) nie zmieniła się formuła kształcenia przedmiotu i w dalszym ciągu nie uczy się studentów przedsiębiorczości praktycznej.

Nieliczna grupa studentów, która już podczas studiów prowadziła swoją działalność gospodarczą, wskazywała, że zajęcia z przedsiębiorczości powinny być prowadzone, ponieważ jest to najlepszy sposób na zachęcenie nowych osób do podejmowania własnych inicjatyw i zmobilizowania do większej aktywności gospodarczej. Zdaniem tej grupy studentów edukacja przedsiębiorczości powinna być prowadzona na każdym szczeblu edukacji. Z kolei na studiach ekonomicznych powinna być obowiązkowa i objęta szczególną troską zarówno uczelni, jak i administracji państwowej. Badani podkreślali, że przedsiębiorczość powinna być kursem realizowanym na każdym kierunku studiów, ponieważ gospodarka rynkowa wymaga, by przedstawiciele każdego kierunku potrafili myśleć o swojej dziedzinie jako biznesie. To nowe spojrzenie na przedsiębiorczość pokazuje, że młodzi ludzie z doświadczeniami biznesowymi dostrzegają istotę przedsiębiorczości i kreowania jej u przedstawicieli wszystkich kierunków studiów.

Studenci podkreślali podczas badań, że dużą wagę w całym kształceniu przywiązuje się do ukazywania tematu uruchomienia własnej 
firmy. Wiedza, którą otrzymują podczas zajęć, mimo że jest podparta często przykładami, okazuje się niewystarczająca i w efekcie studenci nie wiedzą, jakie kroki podjąć, aby otworzyć działalność. Wskazywali też, że po skończeniu kursu z przedsiębiorczości raczej obawiali się zakładać swoją firmę, ponieważ na zajęciach wskazywano także na trudności i problemy, na które mogą natrafić na swojej drodze. Często właśnie te czynniki i strach przed nieznanym hamowały ich przed otwieraniem działalności. Kolejnym zniechęcającym czynnikiem był brak jakiegokolwiek wsparcia w tym zakresie ze strony państwa. Badani wskazywali często, że nie wiedzą, do jakich urzędów muszą pójść, jak wypełniać dokumenty, gdzie i kogo pytać o porady oraz jaką formę prawną działalności wybrać. Problemem jest także planowanie działań, analizowanie oferty konkurencji, działania marketingowe produktu czy usługi lub całość spraw związanych z częścią kadrowo-finansową. Studenci obawiali się, że w przypadku pytań lub problemów nie będą wiedzieli, gdzie szukać pomocy. Przykłady, które podawali ich koledzy i koleżanki prowadzący już działalność, potwierdzały te obawy.

Osoby, które w trakcie trwania badania prowadziły firmy, twierdziły, że uczęszczając na studiach na zajęcia z przedsiębiorczości i korzystając tylko z nich, nie podjęłyby decyzji o otwarciu własnej działalności. Ich zdaniem zajęcia dają tylko informacje, ale nie pozwalają przećwiczyć całego procesu. Zajęcia były ich zdaniem zbyt teoretyczne i nie pokazywały, jak krok po kroku, mając pomysł, założyć działalność. Część badanych wskazała także, że liczba zajęć była niewystarczająca, by można było takie ćwiczenia przeprowadzić. Ponadto młodzi ludzie stwierdzili, że wiedza potrzebna do prowadzenia własnej działalności jest rozproszona na kilku, a nawet kilkunastu przedmiotach, i nie ma jednego przedmiotu spinającego te wiadomości (Nowiński, Nowaczyk, Sobczak, Tomczyk, Fabiś 2016).

Studenci prowadzący swoje firmy wskazywali, że przy ich zakładaniu korzystali z pomocy innych - firm zewnętrznych lub osób, które przeszły już tę ścieżkę i mogły być dla nich drogowskazem. Większość wskazywała na pomoc rodziny w tym obszarze. Stwierdzali, że edukację dla przedsiębiorczości powinny prowadzić uczelnie, a wykładowców wskazywali jako tych, którzy powinni ukierunkowywać, motywować studentów i umacniać ich w dążeniach do zakładania własnych biznesów. W badaniach pojawiły się sugestie, że wykładowcy bardzo często przekazują tylko wiedzę, ale nie motywują studenta do działań w realnym 
biznesie. Ponadto studenci często zwracali uwagę na jedynie teoretyczne przygotowanie wykładowców. Zdaniem badanych dydaktyk niemający praktyki w prowadzeniu biznesu nie potrafi dostatecznie zainteresować tym tematem studentów, a także motywować ich do posiadania własnego biznesu. Brak doświadczeń z biznesu u wykładowców był odbierany przez studentów jako słabe przygotowanie kadry do prowadzenia zajęć. Młodzi ludzie zwracali też uwagę na to, że na uczelniach brakuje praktyków, którzy przez dłuższy czas spotykaliby się z młodymi ludźmi i zachęcali ich do otwierania działalności gospodarczej. Studenci stwierdzili, że jeden kurs nie spowoduje znaczącego wzrostu zainteresowania otwieraniem firm i potrzebne są działania długofalowe, trwające przez cały okres studiów.

W opinii badanych bardzo ważna jest wiedza na temat uruchomienia własnej firmy, ale także umiejętności jej prowadzenia, np. wypełnianie odpowiednich dokumentów czy sprawy podatkowe lub prawne. Studenci zdają sobie sprawę też z tego, że aby prowadzić firmę $\mathrm{i}$ ją rozwijać, potrzebne są wiedza i umiejętności z zakresu zarządzania. Mimo że badanie było przeprowadzone na kierunkach ekonomicznych, na uwagę zasługuje to, że studenci logistyki i ekonomii wskazywali na braki zarówno w wiedzy i umiejętnościach z dziedziny zarządzania (ludźmi, kosztami i dochodami, czasem), jak i rachunkowości, finansów czy prawa cywilnego i handlowego. Grupa studentów z tych kierunków wprost mówiła, że absolwenci kierunku zarządzanie są lepiej przygotowani do prowadzenia swojego biznesu. Ten wniosek jest ważny w kontekście innych kierunków, na których - jak pokazują badania - uczelnie wręcz wcale albo rzadko $w$ rozkładach zajęć planują przedmioty z zakresu zarządzania. Badani podkreślali też, że sukces na rynku nie zależy wyłącznie od wiedzy i samego pomysłu na biznes, ale od kreatywności, umiejętności planowania, zarządzania czasem, umiejętności pracy w grupie, radzenia sobie ze stresem czy podejmowania ryzyka. Studenci wszystkich kierunków wskazywali, że w czasie studiów bardzo rzadko ćwiczą na zajęciach zarówno te umiejętności, jak i kreatywne rozwiązywanie problemów (Nowiński, Nowaczyk, Sobczak, Tomczyk, Fabiś 2016).

Dla uczestników badania bardzo ważną rolę odgrywają praktyki studenckie, wizyty w firmach, spotkania z ludźmi sukcesu lub osobami, które prowadzą firmy i chcą się dzielić swoim doświadczeniem. Taki praktyczny aspekt kształcenia jest postrzegany jako okazja do słucha- 
nia, podpatrywania i uczenia się od osób, które mają wiedzę praktyczną i uczą, jak postępować w określonych sytuacjach. Studenci wysoko oceniają organizowane spotkania z ciekawymi osobami, pokazujące, jaką drogę biznesową przeszły te osoby oraz z jakimi problemami, wyzwaniami czy wręcz oporem i trudnościami musiały się zmierzyć. Jak podkreślali, wartościowsze jest spotkanie z człowiekiem, który opowiada o prowadzeniu biznesu, pokazując jego ciemne strony i sposoby wychodzenia z tych kryzysów, niż opowiadanie tylko o pozytywach prowadzenia biznesu. Studenci podczas praktyk studenckich chcieliby uczyć się prowadzenia biznesu, ale zdają sobie sprawę z tego, że przedsiębiorcy nie mają czasu, aby poświęcić im dostateczną część uwagi.

Wyniki badania pokazały, że w większości studenci po zakończeniu nauki ani nie są gotowi, ani nie planują otworzyć swojej firmy. Wśród argumentów przeciw zakładaniu własnego przedsiębiorstwa najczęściej wskazywali brak środków finansowych - studenci, którzy chcą wziąć kredyt na otwarcie działalności, stanowili 1 proc. wszystkich badanych. Kolejnym czynnikiem jest strach przed nieznanym oraz tzw. wygodnictwo - „lepiej pracować u kogoś i nie mieć zmartwień, zrobić swoje i mieć wolne". Badani wskazywali także, że rodzina i przyjaciele (którzy najczęściej pracują na etacie) odradzają im otwieranie własnego biznesu, twierdząc, że jest to bardzo trudne i nie ma żadnych gwarancji na powodzenie. Studenci przyznawali, że są zbyt młodzi na prowadzenie własnej firmy i wciąż chcą mieć czas na relaks i życie towarzyskie. Takie postawy wskazują na nieracjonalne szukanie wytłumaczeń i niechęć do podejmowania nowej inicjatywy. Szukanie złych stron prowadzenia własnej działalności można zinterpretować jako szukanie wytłumaczenia wygodnictwa, na które skazują się młodzi ludzie. Studenci, myśląc o sobie na rynku pracy, widzą siebie raczej jako pracowników, a nie jako pracodawców. Taka sytuacja potwierdza ogólny nastrój niechęci do zakładania własnego biznesu. Młodych ludzi w prowadzeniu swojej firmy pociągają najczęściej pieniądze i możliwość elastycznego czasu pracy jako wartości. Jednak zdają sobie sprawę, że zarobienie wystarczającej i satysfakcjonującej sumy pieniędzy może być rozciągnięte $w$ czasie.

Z kolei badane osoby, które już prowadziły działalność, nie podejmowały tematu pieniędzy, a czynnik "elastyczny czas pracy" oznaczał dla nich pracę przez 24 godziny na dobę. Ta grupa badanych ochoczo wypowiadała się o argumentach za otwarciem własnej firmy i prze- 
ciw niemu, chętnie nawiązywała do własnych problemów i dzieliła się doświadczeniami. Do prowadzenia własnej działalności najczęściej zachęcały ją: możliwość decydowania o sobie, budowania czegoś trwałego dla swojej rodziny, elastyczny czas pracy oraz korzyści finansowe.

Warto też zwrócić uwagę na optymistyczne stwierdzenie osób, które $w$ trakcie trwania badania pomagały swoim bliskim w prowadzeniu firmy-obecnie chcą zdobyć doświadczenie, pracując u kogoś innego, lub zaoszczędzić pieniądze na własny biznes, a w przyszłości założyć swoją działalność. Część studentów, których bliscy lub znajomi prowadzą działalność, liczy w przyszłości na ich pomoc przy otwieraniu własnej. Wszyscy podkreślali, że jeśli spotykają na co dzień osoby prowadzące działalność, które są zadowolone z siebie i zmotywowane, to taka postawa działa na nich również motywująco. Wniosek: spełnieni przedsiębiorcy zarażają innych swoim entuzjazmem i zachęcają do realizacji własnych planów oraz marzeń o działalności. Studenci wskazywali, że obserwują osoby prowadzące własny biznes oraz rozmawiają z nimi i z tych doświadczeń czerpią siłę oraz zapał do zakładania własnego biznesu.

Badani, którzy nie prowadzą samodzielnie działalności, zapytani, czy mają wystarczającą ilość informacji, by uruchomić firmę, odpowiedzieli, że nie. Wiedzy na temat otwarcia biznesu poszukują najczęściej w internecie. Tylko nieliczni wskazali, że przy zakładaniu działalności kontaktowaliby się ze swoimi wykładowcami z uczelni.

Opinie na temat pomysłów na poprawę kształcenia przedsiębiorczości na uczelniach i budzenia wśród studentów ducha przedsiębiorczości były podzielone. Jedni wskazywali na większą liczbę ćwiczeń wykonywanych samodzielnie i podejmowanie decyzji tak, aby późniejsze rezultaty omawiać na zajęciach. Były też osoby, którym odpowiadałyby zajęcia z prowadzenia firmy najlepiej w postaci gry komputerowej. Kolejne wskazywały na odbywanie wizyt studyjnych w firmach i instytucjach oraz spotkania z przedsiębiorcami, którzy mogliby opowiadać o prowadzeniu własnego biznesu wraz z możliwością zadawania pytań (Nowaczyk, Sobczak 2016).

\section{Przedsiębiorczość wśród seniorów}

Przedłużenie długości życia i poprawa ogólnej zdrowotności społeczeństw krajów wysoko rozwiniętych spowodowały, że okres aktywności zawodowej ludności znacznie się wydłużył. Przedsiębiorczość 
wśród seniorów dotyczy zarówno osób z grupy 50+, jak i tych, które są już $w$ wieku emerytalnym. $Z$ analizy badań własnych przeprowadzonych w 2018 r. na uniwersytetach trzeciego wieku, raportów badań przeprowadzonych w Europie i dostępnej literatury wynika, że skłonność do podejmowania własnej działalności gospodarczej maleje wraz z wiekiem (Wach 2015). Przedsiębiorczość grupy 50+ w Polsce wynika z wywierania wpływu przez pracodawców na tę grupę, aby współpracowała z przedsiębiorstwami jako grupa samozatrudnionych. Grupa ta zakłada własną działalność, ponieważ tylko $w$ taki sposób może w dalszym ciągu pracować na danym stanowisku i wykonywać pracę. Przedsiębiorcy, eliminując koszty osobowe, zachęcają swoich pracowników do prowadzenia samodzielnie działalności, mimo że spora część z nich nie chce takiego rozwiązania. Mówimy wtedy o „wymuszonej przedsiębiorczości”, kiedy to impuls do otwarcia działalności nie pochodzi od osoby, ale jest jej narzucony przez otoczenie. Często dojrzali przedsiębiorcy w wieku emerytalnym nie rezygnują z prowadzenia firmy, nawet jeśli osiągnęli wysoką pozycję materialną i ich bieżące oraz przyszłe potrzeby materialne są już zabezpieczone.

Członkowie uniwersytetu trzeciego wieku, wśród których były prowadzone badania w 2018 r., wskazali, że brakuje im postaw przedsiębiorczych, a co za tym idzie - tylko około 2 proc. respondentów myślało o zakładaniu własnego przedsiębiorstwa. Tak niski wskaźnik potwierdza miejsce Polski wśród grupy krajów o najniższym wskaźniku aktywności przedsiębiorczej seniorów, skonstruowanym na podstawie badań przeprowadzonych w 28 krajach Unii Europejskiej (por. Pilkova, Holienka, Rehak 2014). Seniorzy nie chcą podejmować nowych form działalności i aktywności, powołując się na to, że już są na emeryturze i chcą odpoczywać, a nie pracować. Stwierdzają, że to młodzi powinni zakładać nowe firmy, a nie oni. Taka postawa potwierdza wyniki badań światowych o tym, że emeryci w Polsce nie są zainteresowani podejmowaniem aktywności zawodowej poprzez otwieranie działalności. Nieliczna grupa, która decyduje się na to najczęściej, podjęła decyzję o przejściu na emeryturę przed 60. rokiem życia. Zakładają oni działalność, ponieważ są zdrowi, chcą robić nowe rzeczy, chcą pozostawać aktywni zawodowo i realizować się w ten sposób. Bardzo rzadko impulsem do zakładania firmy są pobudki finansowe. Seniorzy chcą się realizować, spełniać swoje marzenia i czuć się potrzebni. Czasami podejmują decyzję o zakładaniu własnej firmy, ponieważ nie mogą 
znaleźć zatrudnienia u pracodawców i jest to jedyne rozwiązanie, aby dalej pozostawać na rynku pracy.

W wyniku starzenia się społeczeństw rynek pracy się zmienia i obecni pracownicy z grupy 50+ będą podejmować częściej decyzję o założeniu działalności. Właśnie taka forma będzie gwarantowała im zatrudnienie $u$ dotychczasowego pracodawcy lub pozwalała pozostawać na rynku pracy. Ponadto pojawia się coraz więcej wolnych zawodów i ludzie wykonujący daną pracę nie myślą o odejściu na emeryturę. Wydaje się, że tak w przyszłości będzie wyglądał rynek pracy seniorów - będą oni aktywni zawodowo, ale będą wybierać między ofertami, uwzględniając możliwości fizyczne, stopień zaangażowania oraz potrzeby finansowe.

\section{Podsumowanie}

Bardzo mały odsetek młodych ludzi podejmuje się otwarcia swojego biznesu. Młodym wygodniej jest pracować u innych, natomiast seniorzy chcą pracować dla siebie, bo już napracowali się dla kogoś. Seniorzy rzadziej podejmują decyzję o otwieraniu działalności ze względów finansowych, natomiast dla młodych ludzi jest to jeden z najważniejszych argumentów przy podejmowaniu decyzji. Starsze osoby wykazują mniejszą niż młodzi skłonność do przebranżowienia się i wprowadzania innowacji podczas otwierania swojej działalności. W porównaniu z ludźmi młodymi rozpoczynającymi karierę biznesową atutami seniorów są: wiedza, doświadczenie oraz kontakty. Prowadzenie firmy będzie wymagało dużego wysiłku, w tym umiejętności radzenia sobie ze stresem i podejmowania ryzyka, czego mogą obawiać się seniorzy. Studenci i seniorzy to dwie grupy nastawione na rozwój, jednak ich spojrzenie na przedsiębiorczość i podejmowanie decyzji o otwieraniu działalności jest bardzo odmienne. Właśnie ta odmienność powoduje, że każda z tych grup ma szansę na rynku pracy. 


\section{Bibliografia}

$\rightarrow$ Borowiec-Gabryś, M., Kilar, W., Rachwał, T. (2018), Przedsiębiorczość jako kompetencja przyszłości [w:] Kompetencje przyszłości, S.M. Kwiatkowski (red.), Warszawa: Wydawnictwo FRSE, s. 74.

$\rightarrow$ Entrepreneurship education. Opportunities and Challenges for Universities in Visegrad Countries, ed. by D. Egerova (2016), Pilzno: NAVA, s. 56-57.

$\rightarrow$ Nowaczyk, G., Sobczak, A., Role of entrepreneurship education in higher education institutions in the proces of business development in Poland [w:] Entrepreneurship: Antecedents and Effects, ed. by M. Kosała, M. Urbaniec, A. Żur, „Przedsiębiorczość Międzynarodowa”, nr 2/2016, s. 43-52.

$\rightarrow$ Nowiński, W., Nowaczyk, G., Sobczak, A., Tomczyk, Ł., Fabiś, A. (2016), Innowacyjna edukacja przedsiębiorczości, Raport krajowy, Poznań-Oświęcim-Kraków: Wyższa Szkoła Bankowa w Poznaniu, Państwowa Wyższa Szkoła Zawodowa w Oświęcimiu, Uniwersytet Pedagogiczny w Krakowie, s. 21-27, 31-38.

$\rightarrow$ Pilkova, A., Holienka, M., Rehak, J. (2014), Senior Entrepreneurship in the Perspective of European Entrepreneurial Environment, "Procedia Economics and Finance", nr 12, s. 523-532, doi: 10.1016/S2212-5671(14)00375 - X.

$\rightarrow$ Wach, K. (2015), Przedsiębiorczość seniorów jako komponent przedsiębiorczości inkluzywnej: wstępna synteza, „Horyzonty Wychowania”, Vol. 14, No 32. 


\section{Netografia}

$\rightarrow$ Przedsiębiorstwa niefinansowe powstałe w 2017 rok, tat.gov.pl/obszary-tematyczne/podmioty-gospodarcze-wyniki-finansowe/przedsiebiorstwa-niefinansowe/przedsiebiorstwa-niefinansowe-powstale-w-2017-roku,25,1.html (dostęp: 3.12.2018).

$\rightarrow$ Przedsiębiorczość w szkolnictwie wyższym, szczególnie na studiach nieekonomicznych, Streszczenie Sprawozdania końcowego grupy ekspertów, Komisja Europejska, 2008, ec.europa.eu/docsroom/documents/8969/attachments/1/ translations/pl/.../native (dostęp: 3.12.2018).

$\rightarrow$ Studia pierwszego i drugiego stopnia w SGH. Programy i plany studiów, dziekanat.sgh.waw.pl/informatory/informator_2018_opis_sl_sm.pdf (dostęp: 27.11.2018).

$\rightarrow$ Światowy Raport Amway o przedsiębiorczości AGER 2018, networkmagazyn.pl/ swiatowy-raport-amway-o-przedsiebiorczosci-ager-2018 (dostęp: 3.12.2018). 


\title{
Dobre praktyki \\ edukacji pozaformalnej
}

\author{
Renata Rettinger
}

Edukacja pozaformalna to uznany i coraz bardziej rozpowszechniony sposób zdobywania i rozwijania kompetencji, uczenia się o świecie, o innych, a także o sobie samym. Nowa ekonomia bazująca na wiedzy, informacji, innowacjach, postępie technologicznym tworzy nowe wyzwania edukacyjne, społeczne, gospodarcze i polityczne. Powyższe cele można realizować przez edukację pozaformalną. Współcześnie obserwuje się przesunięcie akcentu z edukacji formalnej, w której wiedza ma charakter obiektywny, na rzecz edukacji pozaformalnej. Głównym celem artykułu jest analiza inicjatyw edukacyjnych z zakresu kształtowania postaw przedsiębiorczych realizowanych $w$ różnych formach i przez różne organizacje.

\section{_ Słowa kluczowe: \\ edukacja \\ edukacja pozaformalna \\ postawy przedsiębiorcze \\ przedsiębiorczość}




\title{
Good practices \\ in non-formal education
}

\author{
Renata Rettinger
}

Non-formal education is a recognized and increasingly widespread way of acquiring and developing competence, also learning about the world, others, and yourself. New economy is based on knowledge, information, innovation, technological progress. It creates new educational, societal, economic, and political challenges. Above goals can be realized through non-formal education. Nowadays the emphasis on formal education, were the knowledge has an objective character, is shifting towards non-formal education. The main goal of this paper is the analysis of the educational initiatives from the scope of basic entrepreneurship realised through different forms and by different organizations.

\section{Keywords: \\ education \\ non-formal education \\ entrepreneurial attitudes \\ entrepreneurship}




\section{Wstęp}

Współczesne tendencje rozwoju cywilizacyjnego na świecie, a w szczególności rozwój gospodarki opartej na wiedzy i kształtowanie społeczeństwa informacyjnego, powodują powstanie nowych wyzwań przed procesem edukacji na wszystkich jej poziomach (Dorocki, Kilar, Rachwał 2011; Piróg 2005; Stalończyk 2014; Wach 2013). Ta zmiana powinna polegać na dostosowaniu celów, treści, metod i zakładanych efektów kształcenia szkolnego do wyzwań czekających młode pokolenie w szybko zmieniających się realiach społeczno-gospodarczych. Należy sobie postawić pytanie: Czy system edukacji w Polsce jest w stanie sprostać wymaganiom współczesnego świata, przed którymi staje polski obywatel, gdzie nieustanny postęp technologiczny, innowacje, globalizacja wywierają tak ogromny wpływ na życie każdego z nas (Stalończyk 2014)? Bezsprzecznie kształcenie jest podstawą do budowania kapitału intelektualnego społeczeństwa (Rachwał, Wach 2016; Borowiec-Gabryś, Kilar, Rachwał 2018). Nauka szkolna stanowi tylko jedną część składową edukacji globalnej, jest ona uzupełniana o kształcenie i wychowanie pozaformalne, które odbywa się w szkole i poza nią, wybiega poza program szkolny i staje się bardziej czułe na zmiany dokonujące się w świecie. Należy pamiętać - aby jednostka potrafiła wykorzystać wszelkie możliwości uczenia się i doskonalenia, musi zdobyć dobre wykształcenie formalne (szkolne) i w efektywny sposób korzystać z innych form edukacji, a w szczególności z pozaformalnych (Trempała 2011).

W polskim szkolnictwie nadal dominuje klasyczny model nauczania. Natomiast współczesny model kształcenia przedsiębiorczego wymaga natychmiastowej implementacji, i to na szeroką skalę, co z kolei wymaga odpowiedniego przeszkolenia nauczycieli, ale przede wszystkim sporych nakładów finansowych na wyposażenie szkół i uczelni publicznych (Wach 2013). Niemniej istnieje pilna potrzeba zapewnienia wsparcia metodycznego dla nauczycieli przedsiębiorczości w zakresie wykorzystania aktywnych metod nauczania (m.in. takich jak moderacja wizualna, blended e-learning, edutainment). Aktywizujące metody nauczania powinny być szeroko stosowane w edukacji ekonomicznej na wszystkich poziomach edukacji szkolnej. Kształcenie takie wymaga zatem stosowania szerokiego wachlarza metod aktywizujących, szczególnie aktywizujących metod problemowych wyzwalających w uczących się własną inicjatywność (tamże). Jednym ze sposobów wdrożenia 
tych zmian w sposób kształcenia kompetencji przedsiębiorczych jest udział uczniów w inicjatywach edukacyjnych proponowanych w ramach edukacji pozaformalnej.

\section{Edukacja pozaformalna}

Edukacja formalna obejmuje naukę w systemie szkolnym. Kształcenie odbywa się w instytucjach szkolnych i edukacyjnych - zarówno państwowych, jak i prywatnych - zgodnie z odgórnie zatwierdzonymi programami i planami nauczania. Edukacja ta prowadzi w kierunku uzyskania kwalifikacji potwierdzonych świadectwem, zaświadczeniem o skończeniu szkoły, certyfikatem, dyplomem (Stalończyk 2014). W. Okoń (1998) definiuje kształcenie nieformalne/pozaformalne jako świadomą i zorganizowaną działalność o charakterze kształcenia i wychowywania, prowadzoną poza ustawowym formalnym systemem szkolnym, umożliwiającą określonej grupie uczestników osiągnięcie założonych celów kształcenia.

Edukacja pozaformalna w Polsce jest w początkowej fazie rozwoju, natomiast na arenie międzynarodowej stała się częścią polemiki nad polityką edukacyjną w latach 60. i 70. XX w. M. Fordham (1993) wyodrębnił cztery kluczowe elementy związane z kształceniem pozaformalnym:

$\rightarrow$ miejsce realizacji zajęć wyznaczone jest zarówno w obrębie instytucji edukacyjnych, jak i poza nimi,

$\rightarrow$ uczestnicy to osoby w różnym przedziale wiekowym, lecz o ściśle określonych potrzebach,

$\rightarrow$ program kształcenia pozaformalnego skoncentrowany jest na osiągnięciu określonych celów,

$\rightarrow$ elastyczność w organizacji i metodach nauczania, przekazywania wiedzy.

Edukacja pozaformalna obejmuje wszelkie zorganizowane, systematyczne działania edukacyjne, prowadzone poza ramami formalnego systemu, tak aby zapewnić poszczególne formy uczenia się różnym grupom wiekowym. Kształcenie pozaformalne jest elementem łączącym kształcenie ustawiczne z kształceniem przez całe życie. Uczenie się jest nieodzownym elementem naszej egzystencji, umożliwiającym adaptację do niestabilnych warunków życia. Jest to powód, dla którego nowa rzeczywistość edukacyjna przesycona jest ideą całożyciowego uczenia się (Marcinkiewicz 2013). Inwestycje związane z kształceniem 
podnoszą w sposób bezpośredni jakość kapitału ludzkiego. A on budowany jest przez rodzinę, środowisko, wzbogacany przez szkołę oraz system norm i dopiero w dojrzałej formie dostępny jest gospodarce. Tam może być rozwinięty i wykorzystany bądź stłamszony i zamordowany (Galar 2009).

\section{Formy oraz efektywność edukacji pozaformalnej}

Z każdym rokiem rośnie znaczenie edukacji pozaformalnej jako wyniku procesów dostosowawczych, zwiększających elastyczność rynku pracy w warunkach dynamicznie zmieniających się potrzeb społeczeństwa. Edukacja pozaformalna staje się coraz częściej ważnym źródłem wiedzy, umiejętności i kompetencji (Dziechciarz 2015). Zwiększone zapotrzebowanie ze strony osób podnoszących swoje kwalifikacje lub rozszerzających swoje kompetencje wymusza zmiany w ofercie kształcenia pozaformalnego. Popularność tego typu kształcenia skutkuje tworzeniem bogatej oferty form organizacyjnych. Edukacja pozaformalna to programy szkoleniowe świadczone przez instytucje społeczne, takie jak: biblioteki, muzea, szkoły muzyczne, szkoły językowe, domy kultury, teatry i inne organizujące aktywne formy spędzania wolnego czasu. Edukacja pozaformalna (non-formal education) odnosi się do aktywności edukacyjnych, sytuujących się poza formalnym systemem oświaty, takich jak: kursy, seminaria, odczyty koła miłośników, różne formy dokształcania, studia podyplomowe (Marcinkiewicz 2013).

Edukacja pozaformalna jest skierowana do różnych grup wiekowych. Decyzja o udziale w tego typu kształceniu może być podejmowana dobrowolnie w przypadku młodzieży uniwersyteckiej czy osób starszych lub inspirowana przez nauczyciela na niższych poziomach edukacyjnych. W przypadku dzieci i młodzieży edukacja pozaformalna powinna być atrakcyjna i interesująca, tak aby zaszczepić chęć do ciągłego uczenia się, rozwijania talentów i umiejętności. Współcześnie obserwuje się przesunięcie akcentu z edukacji formalnej, w której wiedza ma charakter obiektywny, a jej celem jest wyposażenie jednostki w kompetencje "twarde", na rzecz edukacji pozaformalnej, gdzie wiedza jest intersubiektywna i oferuje kompetencje "miękkie" (Marcinkiewicz 2013).

Kształcenie pozaformalne w połączeniu z formalnym charakteryzuje się bardzo dużą efektywnością. Można użyć sformułowania, że jest ono katalizatorem kształcenia formalnego. Aktywne uczestnictwo w projek- 
cie, realizacji zadania to aż 90 proc. zapamiętanej wiedzy. Pozaformalne uczenie się nie jest obowiązkiem, lecz przyjemnością lub bardzo często wyborem. Uczestnikom proponuje się wspólną realizację projektów oraz aktywne uczestnictwo w różnego rodzaju warsztatach i pracach zespołowych. Uczenie się poza szkołą jest efektywne, ponieważ zaangażowanie uczestnika aktywuje jego proces poznawczy. W ten sposób uczestnicy odkrywają swoje talenty, są zadowoleni z osiągniętych celów, budują więzi społeczne, kształtują poglądy i aktywnie spędzają czas. Kształtowane są pożądane postawy obywatelskie, takie jak odpowiedzialność społeczna, umiejętność porozumiewania się w grupie, szacunek dla innych osób, umiejętność szybkiego podejmowania decyzji, odwaga i upór w dążeniu do realizacji swoich celów oraz najważniejsze: potrzeba wzbogacania wiedzy. Uczestnictwo dobrowolne, oparte na pluralizmie działań, pozwala na indywidualność i samodzielność wyboru pomiędzy ofertami składanymi przez różnorodne pozaszkolne ośrodki edukacji a proponowanymi formami pracy i treściami charakteryzującym nowość (aktualność), innowacyjność, siła przyciągania, różnorodność i adekwatność wobec potrzeb i oczekiwań (Trempała 2011). Najważniejszym problemem jest powiązanie edukacji formalnej z pozaformalną, czyli w planowanej pracy nauczycieli szkolnych powinny znaleźć odbicie wielorakie nieszkolne wpływy edukacyjne, oddziałujące na uczniów, czyli cały proces kształcenia i wychowania szkolnego należy włączyć w nurt dopełniających go oddziaływań nieszkolnych.

Stroną organizacyjną edukacji pozaformalnej zajmują się liczne instytucje i organizacje publiczne, prywatne oraz podmioty organizacyjne wchodzące w skład sektora non profit. W Polsce po 1989 r. organizacje pozarządowe zaczęły pojawiać się masowo, wynikało to w dużej mierze z procesów demokratyzacji kraju i tworzenia się społeczeństwa obywatelskiego (Rudnicki 2015). Charakter polskiego systemu edukacyjnego (edukacja formalna) stworzył miejsce dla działań quasi-instytucji zajmujących się edukacją pozaformalną, które w ciekawy i nowatorski sposób mają przedstawić oraz przekazać wiedzę bardzo często pomijaną przez placówki oświatowe. Tak właśnie było z edukacją "o" przedsiębiorczości, „dla” przedsiębiorczości i „przez” przedsiębiorczość. Uczelnie wyższe jako instytucje edukacji trwającej przez całe życie nie są jedynie placówkami kształcenia formalnego, lecz także instytucjami, w których odbywa się kształcenie pozaformalne i nieformalne. Ten typ działalności zapewnia dostęp do edukacji na najwyższym poziomie oraz 
kontakt z wykładowcami akademickimi (Marcinkiewicz 2013). Edukacja nieszkolna to wielki i bardzo różnorodny obszar, w ramach którego niektóre instytucje swoją atrakcyjnością zajęć oraz aktualnością wiedzy i informacji prowokują ich uczestników do wyboru różnorodnych form pracy oraz treści kształcących (Trempała 2011).

Problemem, który trzeba będzie w najbliższych latach rozwiązać, jest kwestia uznawalności kształcenia pozaformalnego. Certyfikaty uzyskane w ramach kształcenia pozaformalnego poświadczają jedynie zdobycie pewnego rodzaju wiedzy, umiejętności i kompetencji. Jedną z najpopularniejszych form są studia podyplomowe, które umożliwiają zdobycie w relatywnie krótkim czasie (dwa-cztery semestry) określonych kwalifikacji i kompetencji często o charakterze specjalistycznym (Marcinkiewicz 2012).

\section{Dobre praktyki edukacji pozaformalnej w zakresie przedsiębiorczości}

Mnogość działań edukacyjnych na współczesnym rynku edukacji pozaformalnej wymusza krytyczne podejście do angażowania się szkół w projekty edukacyjne z zakresu szeroko rozumianej przedsiębiorczości. W dalszym ciągu istnieje bardzo duże zapotrzebowanie na prowadzenie dodatkowych zajęć z zakresu kształtowania i rozwijania u uczniów kluczowych kompetencji (społecznych, inicjatywności, przedsiębiorczości) oraz kształtowania właściwych postaw (kreatywności, innowacyjności, pracy zespołowej) niezbędnych na rynku pracy. Dobre przykłady edukacji pozaformalnej to: pikniki naukowe, Centrum Nauki Kopernik, program "Młodzież w działaniu”, uniwersytet trzeciego wieku, wycieczki i obozy przyrodnicze, Noc Muzeów, obozy językowe, festyny naukowe. Proces przeorientowania systemu edukacji jest trudny i długofalowy. Działania nie mogą być tylko odgórne, ponieważ nie będą przynosiły efektów. Współpraca na poziomie lokalnym pomiędzy szkołami a lokalnymi organizacjami, takimi jak domy kultury, teatry, biblioteki, fundacje czy stowarzyszenia, powinna zostać wpisana $w$ ramy polityki edukacyjnej na poziomie wszystkich jednostek samorządu terytorialnego.

Poniżej zostały przedstawione wybrane inicjatywy edukacyjne z zakresu przedsiębiorczości, prowadzone przez różnego rodzaju organizatorów oraz o różnym zakresie wiedzy i stosowanych metodach edukacyjnych. 
Jedną z instytucji państwowych prowadzących również działalność edukacyjną jest Narodowy Bank Polski, który w dokumencie "Priorytetowe obszary edukacji ekonomicznej NBP w 2018 r." za czwarty obszar priorytetowy uznał "Rozbudzanie postaw i zachowań przedsiębiorczych, zarządzanie przedsiębiorstwem". NBP w ramach swojej działalności edukacyjnej wspiera finansowo inicjatywy i projekty z zakresu edukacji ekonomicznej. Dofinansowywane są m.in.: konkursy, olimpiady przedmiotowe, warsztaty, szkolenia, wykłady, konferencje, a publikacje naukowe dystrybuowane są bezpłatnie. Innym przykładem dobrych praktyk są działania NBP w ramach portalu edukacyjnego (www.nbportal.pl/edukacja-w-nbp). Znajduje się tam wiele zasobów, które można wykorzystać w szeroko rozumianej edukacji o przedsiębiorczości. Są to: artykuły, prezentacje, Klub Nauczycieli „Impuls", i-przedsiębiorczość, scenariusze lekcji, gry, komiksy, krzyżówki, filmy, quizy. NBP oferuje również możliwość dofinansowania projektów edukacyjnych w wysokości do 30 tys. zł (Bieńkowska 2017).

Inicjatywy edukacyjne podejmowane są także przez organy samorządu terytorialnego. Do ciekawych należy inicjatywa władz Wrocławia, która nie tylko wpływa na postawy przedsiębiorcze mieszkańców, lecz także przede wszystkim ma pomóc kształtować społeczeństwo obywatelskie (Oficjalny portal internetowy Wrocławia 2018). Według autorów tego projektu jest to nauka przez zabawę, w trakcie której kształtowane są postawy przedsiębiorcze beneficjentów programu, a w szczególności cechy: aktywność i ekspansywność, umiejętność oceny ryzyka i gotowość do jego podjęcia, akomodacja w zmieniających się warunkach, praca w zespole, dostrzeganie szans $i$ ich wykorzystanie, innowacyjność. Długofalowymi celami Programu Edukacja Przedsiębiorczości są: popularyzacja przedsiębiorczości jako kompetencji pożądanej na rynku pracy oraz - nie mniej ważne - powstawanie w przyszłości we Wrocławiu większej liczby firm, konkurencyjnych w warunkach gospodarki rynkowej (www.wroclaw.pl). W ciągu 10 lat funkcjonowania programu zrealizowano 19 przedsięwzięć. Wszystkie materiały szkoleniowe są upublicznione na stronie programu i mogą z nich korzystać inne samorządy, organizacje pozarządowe, instytucje oświatowe i osoby prywatne. We Wrocławiu w ramach programu uruchomiono innowacyjny dwuletni projekt "Słowa mają moc". W trakcie jego trwania 26 nauczycieli zostanie przeszkolonych z innowacyjnych technik prowadzenia zajęć, 390 uczniów będzie się szkoliło z efektyw- 
nej komunikacji, a 1170 uczniów dowie się więcej o biznesie dzięki kontaktom z innowatorami zaproszonymi na cykliczne spotkania do szkół.

W Lublinie rusza pilotażowy projekt „Przedsiębiorcze dzieciaki”. Zostanie nim objętych 200 dzieci z Lublina w wieku 6-10 lat. Celem przedsięwzięcia jest nauka postaw przedsiębiorczych, które w przyszłości będą przydatne na rynku pracy i pomogą w rozwijaniu kariery zawodowej. Projekt "Przedsiębiorcze dzieciaki" powstał z inicjatywy Wydziału Strategii i Obsługi Inwestorów Urzędu Miasta Lublina i Wydziału Pedagogiki i Psychologii UMCS (Lublin Miasto Inspiracji 2018). Pierwsza, pilotażowa edycja trwała od marca do czerwca 2018 r. Wzięło w niej udział dziewięć placówek oświatowych z Lublina i okolic. O przedsiębiorczości uczyło się ponad 350 dzieci pod kierunkiem 23 nauczycieli i 11 studentów z Koła Naukowego Pedagogów i Animatorów Zabawy. Tematyka projektu koncentrowała się na przedsiębiorczości rozumianej jako twórcza i kreatywna postawa oraz umiejętność prezentowania pasji, radzenia sobie ze stresem i pozyskiwania środków finansowych na spełnianie marzeń. Partnerami akcji był Bank Millennium oraz Narodowy Bank Polski. Częścią projektu była również wizyta w lubelskich firmach, które z powodzeniem zaprezentowały się przedszkolakom i uczniom.

Ciekawy projekt edukacyjny został zorganizowany z kolei przez Gdański Inkubator Przedsiębiorczości Starter i miasto Gdańsk (Portal Miasta Gdańska 2018). Od 2014 r. w Lekcjach Przedsiębiorczości łącznie wzięło udział ponad 2,5 tys. uczniów. Program oferuje zgamifkowane zajęcia z przedsiębiorczości, podczas których młodzież zdobywa biznesową wiedzę na specjalnej platformie działającej podobnie do znanych gier. Celem programu jest zmiana sposobu uczenia przedsiębiorczości w gimnazjach i liceach, rozwijanie ich kompetencji oraz postaw przedsiębiorczych.

Bardzo często inicjatywy w obszarze edukacji przedsiębiorczości podejmowane są przez organizacje pozarządowe. Jedną z ważniejszych organizacji jest Fundacja Młodzieżowej Przedsiębiorczości (www.junior.org.pl). Jest to pozarządowa organizacja pożytku publicznego, której celem jest przygotowanie dzieci i młodzieży do życia w warunkach gospodarki rynkowej oraz umożliwienie młodym ludziom zdobycia wiedzy i praktycznych umiejętności ułatwiających realizację planów zawodowych. Fundacja Młodzieżowej Przedsiębiorczości jest trzecią co do wielkości organizacją Junior Achievement na świecie pod względem liczby uczniów - w programach wzięło już udział ponad $7 \mathrm{mln}$ 
młodych ludzi. W ofercie fundacji znajdują się następujące programy: "Od grosika do złotówki”, „Ekonomia na co dzień", „Dzień Przedsiębiorczości”, "Młodzieżowe miniprzedsiębiorstwo", „Moje finanse”, „Podstawy przedsiębiorczości”, „Zarządzanie firmą".

Kolejne dobre praktyki to inicjatywy Fundacji Obywatelskiego Rozwoju (FOR) realizowane we współpracy m.in. z MEN i Ośrodkiem Rozwoju Edukacji. Każda edycja programu to konkurs na komiksy o tematyce ekonomicznej, scenariusze lekcji, animacje czy możliwość zaproszenia przedstawicieli projektu do poprowadzenia wybranych lekcji w szkole (Bieńkowska 2017).

W edukację pozaformalną wpisują się działania w zakresie rywalizacji uczniowskiej i studenckiej w ramach olimpiad przedmiotowych. Do takich inicjatyw należy m.in. Szkolna Olimpiada Przedsiębiorczości (od 2005 r.), której organizatorem jest Fundacja Promocji i Akredytacji Kierunków Ekonomicznych (od 2008 r. prowadzi też dwa ogólnopolskie projekty edukacyjne - Akademię Młodego Ekonomisty oraz Ekonomiczny Uniwersytet Dziecięcy). Celem tych projektów jest popularyzacja wiedzy i budowanie świadomości ekonomicznej dzieci i młodzieży (Fundacja Promocji i Akredytacji 2018). Organizacja podejmuje także wiele działań służących doskonaleniu jakości kształcenia w polskich szkołach wyższych oraz propagowaniu i wspieraniu jego najlepszych wzorców. Olimpiada Przedsiębiorczości jest formą współzawodnictwa edukacyjnego, podczas którego oceniane są wiedza, umiejętności oraz postawy ( $w$ tym przede wszystkim szeroko rozumiane postawy przedsiębiorcze), a także wyrażające je zachowania przedsiębiorcze.

Kolejną inicjatywą skierowaną do studentów kierunków ekonomicznych jest konkurs "Przedsiębiorczość, finanse i zarządzanie” (Fundacja Edukacyjna Przedsiębiorczości 2018). Zespoły studentów sprawdzają w nim swoją wiedzę i umiejętności, mierząc się z praktycznymi problemami występującymi w przedsiębiorstwach, oraz próbują swoich sił w negocjacjach. Misją konkursu jest promowanie integracji wiedzy z zarządzania i finansów, podstawowym zaś celem weryfikacja wiedzy i umiejętności nabytych na studiach oraz sprawdzenie zastosowania ich w praktyce. W 22 edycjach konkursu wzięło udział ponad 1,7 tys. studentów reprezentujących uczelnie wyższe z całej Polski.

Wiele instytucji i organizacji podejmuje działania zmierzające do kooperacji i wspierania metodycznego oraz szkoleniowego nauczycieli z zakresu przedsiębiorczości. W takie działania wpisują się oferty 
uniwersytetów proponujące studia podyplomowe, które są odpowiedzią na stale rosnącą konieczność zdobywania lub pogłębiania wiedzy teoretycznej z zakresu przedsiębiorczości oraz potrzebę doskonalenia umiejętności praktycznych. Konieczne są dalsze działania mające na celu organizacyjne, merytoryczne i metodologiczne wsparcie nauczycieli uczących na różnych poziomach edukacyjnych w zakresie przedsiębiorczości (Tracz, Rachwał 2007, Dorocki, Kilar, Rachwał 2011).

\section{Podsumowanie}

W dziedzinie wychowania i kształcenia współczesne społeczeństwo faktycznie nie zaspokoi swoich potrzeb za pośrednictwem jednej instytucji szkolnej, nawet najbardziej rozbudowanej. Koniecznością stało się wejście na rynek usług edukacyjnych organizacji i instytucji działających w edukacji pozaformalnej. Podmioty działające w obrębie edukacji pozaformalnej przejęły funkcję edukacji szkolnej w zakresie tematyki i metod upowszechniania wiedzy, marginalizowanej lub nieobecnej. Taka sytuacja istnieje w zakresie edukacji „o" przedsiębiorczości i „dla” przedsiębiorczości, szczególnie na niższych poziomach edukacyjnych. Edukacja pozaformalna przejęła inicjatywę tworzenia aktywnych, innowacyjnych form edukacji na różnych poziomach edukacyjnych. 


\section{Bibliografia}

$\rightarrow$ Bieńkowska, B. (2017), Przedsiębiorczość i innowacyjność - próba refleksji nad ich miejscem w systemie oświaty [w:] „Research Papers of the Wroclaw University of Economics/Prace Naukowe Uniwersytetu Ekonomicznego we Wrocławiu", (489), s. 44-56.

$\rightarrow$ Borowiec-Gabryś, M., Kilar, W., Rachwał, T. (2018), Przedsiębiorczość jako kompetencja przyszłości [w:] S.M. Kwiatkowski (red.), Kompetencje przyszłości, Seria Naukowa, t. 3, Warszawa: Fundacja Rozwoju Systemu Edukacji, s. 68-89.

$\rightarrow$ Dorocki, S., Kilar, W., Rachwał, T. (2011), Założenia i cele projektu „Krok w przedsiębiorczość" dla nauczycieli szkół ponadgimnazjalnych [w:] „Przedsiębiorczość - Edukacja", nr 7, s. 308-320.

$\rightarrow$ Dziechciarz, J. (2015), Pomiar i wycena wiedzy, umiejętności i kompetencji nabytych $w$ formalnych i nieformalnych formach kształcenia/Measurement and Valuation of Knowledge, Skills and Competence Acquired in the Formal and Informal Education Forms, s. 25-42.

$\rightarrow$ Galar, R. (2003), Gospodarka oparta na wiedzy - sześć wątpliwości, [w:] A. Kukliński (red.), Gospodarka oparta na wiedzy. Perspektywy Banku Światowego w Polsce, Biuro Banku Światowego w Polsce, KBN, Warszawa.

$\rightarrow$ Marcinkiewicz, A. (2012), Kształcenie podyplomowe wobec rynku pracy, "E-mentor", nr 2, s. 54-60.

$\rightarrow$ Marcinkiewicz, A. (2013), Pozaformalne i nieformalne aspekty edukacji akademickiej, "Ogrody Nauk i Sztuk”, nr 3, s. 46-53.

$\rightarrow$ Okoń, W. (1998), Wprowadzenie do dydaktyki ogólnej, Warszawa: Wydawnictwo Akademickie Żak.

$\rightarrow$ Piróg, D. (2005), Miejsce i rola edukacji europejskiej w nauczaniu podstaw przedsiębiorczości w kontekście współczesnych wyzwań cywilizacyjnych, "Przedsiębiorczość - Edukacja”, nr 1, s. 213-220.

$\rightarrow$ Fordham, P.E. (1993), Informal, non-formal and formal education programmes, YMCA George Williams College ICE301 lifelong learning unit, 2. 
$\rightarrow$ Rachwał, T., Wach, K. (2016), Badanie intencji przedsiębiorczych młodego pokolenia: wyniki ankietyzacji wśród studentów kierunków nieekonomicznych, „Przedsiębiorczość - Edukacja”, nr 12, s. 405-415.

$\rightarrow$ Rudnicki, P. (2015), Edukacja globalna w polskich szkołach, czyli refleksje nad pozaformalnq zmianq w oświacie w trzech ujęciach [w:] M. Kuleta-Hulboj, M. Gontarska (red.), Edukacja globalna: polskie konteksty i inspiracje, Wrocław: Wydawnictwo Naukowe Dolnośląskiej Szkoły Wyższej. s. 60-90.

$\rightarrow$ Stalończyk, I. (2014), Edukacja formalna i pozaformalna w procesie kształtowania społeczeństwa wiedzy, „Nierówności Społeczne a Wzrost Gospodarczy” nr 37, s. 320-332.

$\rightarrow$ Tracz, M., Rachwał, T. (2007), Przedmiot podstawy przedsiębiorczości - założenia realizacji a przygotowanie nauczycieli, „Przedsiębiorczość - Edukacja”, nr 3, s. 286-296.

$\rightarrow$ Trempała, E. (2011), Edukacja formalna (szkolna) i edukacja nieformalna (równoległa, nieszkolna, pozaszkolna), [w:] „Przegląd Pedagogiczny”, nr 1, s. 95-104.

$\rightarrow$ Wach, K. (2013), Edukacja na rzecz przedsiębiorczości wobec współczesnych wyzwań cywilizacyjno-gospodarczych, „Przedsiębiorczość - Edukacja”, nr 9, s. 246-257. 


\section{Netografia}

$\rightarrow$ Oficjalny portal internetowy Wrocławia, www.wroclaw.pl/biznes/edukacja-przedsiebiorczosci (dostęp 8.12.2018).

$\rightarrow$ Lublin Miasto Inspiracji, przedsiebiorczedzieciaki.lublin.eu (dostęp 8.12.2018).

$\rightarrow$ Portal Miasta Gdańska, www.gdansk.pl/inwestycje-miejskie/gdanski-inkubator-przedsiebiorczosci,a,18121 (dostęp: 8.12.2018).

$\rightarrow$ 6. Fundacja Promocji i Akredytacji Kierunków Ekonomicznych, www.fundacja. edu.pl/modul/3/114/297/szkolna_olimpiada_przedsiebiorczosci.html (dostęp: 8.12.2018).

$\rightarrow$ Fundacja Edukacyjna Przedsiębiorczości, fep.lodz.pl/pl/programy/konkurs-przedsiebiorczosc-finanse-i-zarzadzanie (dostęp: 8.12.2018). 


\title{
Metody i formy kształcenia w zakresie innowacyjnej przedsiębiorczości
}

\author{
Agnieszka Skala
}

\begin{abstract}
Kształcenie w zakresie innowacyjnej przedsiębiorczości powinno się różnić od typowego programu nauczania przedsiębiorczości sensu largo. Specyfika przedsięwzięć innowacyjnych wymaga sięgnięcia po szczególne metody i formy kształcenia. W pierwszej części opracowania omówiono specyfikę fenomenu innowacyjnej przedsiębiorczości i obecne problemy edukacji dla przedsiębiorczości dyskutowane w literaturze przedmiotu. W drugiej części przedstawiono propozycję struktury zajęć opartych na pracy projektowej, uwzględniając treści poszczególnych modułów związanych z przekazywaniem wiedzy, rozwijaniem i ćwiczeniem umiejętności oraz kształtowaniem odpowiednich postaw wśród słuchaczy.
\end{abstract}

\section{Słowa kluczowe:}

edukacja dla przedsiębiorczości

przedsiębiorczość innowacyjna

kształcenie projektowe

struktura zajęć 


\title{
Education for Innovative Entrepreneurship - Methods and Forms Applied
}

Agnieszka Skala

\begin{abstract}
New methods and forms of education are applied when it comes to innovative entrepreneurship, instead of "typical" training curriculum. The first part of the text discusses the specificity of the innovative entrepreneurship as an economic phenomenon and the current problems of education for entrepreneurship discussed in the literature. The second part presents a proposal for a project-based curriculum structure, taking into account the content of modules related to transferring knowledge, developing and practicing skills, and shaping appropriate attitudes among the students.
\end{abstract}

\section{Keywords:}

entrepreneurship education

innovative entrepreneurship

project-based learning

curriculum structure 


\section{Innowacyjna przedsiębiorczość}

Powiązanie przedsiębiorczości z innowacyjnością wprowadził do nauk ekonomicznych Joseph Schumpeter (1942), przekonując, że zagrożenie radykalnie lepszymi rozwiązaniami zmusza głównych graczy rynkowych ${ }^{1}$ do ponoszenia nakładów na prace badawczo-rozwojowe, których wdrożenia skutkują rozwojem gospodarczym i cywilizacyjnym. Podobnie Peter Drucker (1992) uważał, że tylko przedsiębiorcy tworzący nowe rynki lub wdrażający nowe rozwiązania reprezentują "prawdziwą" przedsiębiorczość, bez względu na poziom zainwestowanych środków czy wielkość tworzonego przez nich zatrudnienia. W opozycji do tego poglądu wypowiadał się William Baumol (2010) - doceniał imitatorów, którzy dzięki drobnym usprawnieniom (tak zwanym innowacjom inkrementalnym) nierzadko osiągają w dłuższej perspektywie czasowej lepsze wyniki biznesowe niż pionierzy i innowatorzy. Polemika na temat znaczenia innowacji i imitacji pozostaje jednym z nierozstrzygniętych sporów w obszarze badań nad przedsiębiorczością. Jerzy Cieślik (2014) proponuje podejście realne (bliższe Williamowi Baumolowi), uznające imitacje i niewygórowane ambicje przedsiębiorcze za ważne z punktu widzenia rozwoju przedsiębiorczości i całej gospodarki. Podobne stanowisko można znaleźć w pracy Joerna H. Blocka, Christiana O. Fischa i Mirjam van Praag (2017), którzy za innowatorów, poza wynalazcami i naukowcami, uważają także przedsiębiorców lub pracowników, którzy tworzą i wdrażają innowacje raczej umiarkowane.

Nieco inaczej sprawa ta wygląda z punktu widzenia makroekonomii. Odkąd wyniki badań Davida Bircha $(1979,1987)$ wykazały, że to małe firmy (a nie korporacje) tworzą większość nowych miejsc pracy w Stanach Zjednoczonych ${ }^{2}$, zintensyfikowano badania nad wpływem przedsiębiorczości i samozatrudnienia na szeroko rozumiany rozwój gospodarczy i poziom dobrobytu. Wnioski po niemal trzech dekadach badań wciąż nie są w pełni jednoznaczne (Block, Fisch, van Praag 2017). Nie ulega wątpliwości, że większość osób zaangażowanych w tworzenie nowych przedsiębiorstw prowadzi działalność wyłącznie "na własne potrzeby" (subsistence), w ogóle nie zatrudnia pracowników,

1. Używa się także określenia "firmy zasiedziałe" (incumbents).

2. Wnioski te również zostały później podważone - miejsca pracy tworzą głównie firmy młode, a nie małe (Haltiwanger, Jarmin, Miranda 2013), jeszcze innym problemem pozostaje jakość tych etatów (Coad i in. 2014). 
wykazuje minimalne dochody (Shane 2008) i nie przejawia ambicji rozwojowych (Ng, Stuart 2016, Schoar 2010). Nie zmienia to faktu, że wpływ tworzenia nowych firm na liczbę miejsc pracy w krajach OECD jest pozytywny (Calvino, Criscuolo, Menon 2016, Criscuolo, Gal, Menon 2014). Równocześnie inne badania dowiodły, że tylko niewielka liczba udanych wdrożeń przełomowych innowacji, wprowadzanych na rynek zarówno przez firmy zasiedziałe, jak i szybko rosnące start-upy, jest odpowiedzialna za nadproporcjonalne zwiększenie liczby miejsc pracy i wzrost wydajności (Andrews, Criscuolo, Menon 2014). Inaczej mówiąc - mała część przedsiębiorstw odgrywa naprawdę przełomową, napędzającą rolę w gospodarce (por. Cieślik 2018). Są to przedsięwzięcia wdrażające innowacje (nie tylko produktowe), cechuje je ambitna wizja i wysoka dynamika rozwoju, przez to są również ekspansywne i nastawione na rynki globalne. Często występuje w nich komponent technologiczny, nierzadko związany z obszarem ICT ${ }^{3}$. Ich udział w ogólnej liczbie przedsiębiorstw szacuje się na 2-6 proc. (OECD 2015, Wong, Ho, Autio 2005).

Co ciekawe, obserwuje się obecnie tendencję spadkową w zakresie całkowitej liczby rejestracji nowych firm (Blanchenay i in. 2017; Decker i in. 2016), jednocześnie jednak rośnie odsetek przedsięwzięć finansowanych przez fundusze venture capital (VC), podobnie jak wielkość tych inwestycji, które w 2015 r. były o 50 proc. wyższe niż w 2007 r. (w krajach OECD). W Stanach Zjednoczonych odnotowano analogiczną tendencję, a także rosnącą liczbę "jednorożców" (unicorns), czyli innowacyjnych firm branży ICT wycenianych na co najmniej $1 \mathrm{mld}$ dol. amerykańskich (Guzman, Stern 2016).

W tym ujęciu priorytety polityki państw propagujących przedsiębiorczość ulegają przeformułowaniu (Rannikko, Autio 2016, Kösters 2010), co obserwujemy również w Polsce (Stępniak-Kucharska 2015). Celem przestaje być propagowanie przedsiębiorczości jako takiej-zwłaszcza w wymiarze zwiększenia liczby nowych rejestracji - lecz wypracowanie precyzyjnych instrumentów wsparcia dla innowacyjnej, prorozwojowej i dynamicznej przedsiębiorczości. Najciekawsze studia przypadku pokazują, że realne efekty pojawiają się poza głównym nurtem „polityki przedsiębiorczości" i występują w takich obszarach jak ubezpieczenia 
społeczne i zdrowotne (Fairlie, Kapur, Gates 2011), a przede wszystkim - edukacja.

\section{Kształcenie dla innowacyjnej przedsiębiorczości}

Edukacja w zakresie przedsiębiorczości jest uznanym kierunkiem badań naukowych (Kuratko 2005, Vesper, Gartner 1997) oraz kluczowym elementem budowania przedsiębiorczej kultury i gospodarki (McKeown i in. 2006, Matley 2005, Kirby 2004, McMullan, Long 1987), także w Polsce (Sadowska 2016, Wach 2013). Większość uczonych twierdzi zgodnie, że nauczenie się przedsiębiorczości jest możliwe (Fayolle, Lassas-Clerc 2006, Henry i in. 2005a, 2005b), a badania Alberty Charney i Gary'ego Libecapa (2000) dowiodły, że studenci wykształceni w kierunku przedsiębiorczości są nie tylko bardziej skłonni do zakładania własnych firm (co jest raczej oczywistym wnioskiem), ale także wyraźnie częściej niż inni znajdują zatrudnienie w firmach szybko się rozwijających (high-growing) lub realizują ważne projekty związane z rozwojem nowych produktów w ramach dużych organizacji.

W literaturze na temat kształcenia na rzecz przedsiębiorczości dominują prace dotyczące struktury i curriculum zajęć oraz konkretnych technik i metodyk nauczania. Brakuje opracowań przeglądowych i strategicznych, wytyczających najważniejsze kierunki badań oraz omawiających ich zastosowanie. Wiedzę o kształceniu na rzecz przedsiębiorczości można określić jako rozproszoną, a o niedojrzałości tej subdyscypliny świadczą wciąż nierozstrzygnięte spory i dyskusje o definicjach i stosowanej nomenklaturze (Mwasalwiba 2010). Choć nie podlega już dyskusji, że edukacja dla przedsiębiorczości wywiera potężny wpływ na biznes, to nie został jeszcze wypracowany zadowalający warsztat metodyczny, pozwalający na przeprowadzenie badań nad efektywnością zastosowania różnych narzędzi edukacyjnych (por. Skala 2016, Pittway, Cope 2007). Na marginesie tych rozważań warto dodać, że specjalizacja w zakresie edukacji nie jest postrzegana jako kierunek badawczy gwarantujący szybką karierę akademicką, w każdym razie istnieją inne specjalizacje w obszarze przedsiębiorczości, które są odbierane jako bardziej atrakcyjne pod tym względem (Kuckertz, Prochotta 2018, Kuckertz 2013). Grozi to negatywnym wyborem tej specjalności przez młodych naukowców.

W wymiarze kształcenia na rzecz przedsiębiorczości innowacyjnej wśród trzech głównych składowych edukacji przedsiębiorczości 
- ekonomicznej, biznesowej (zarządczej) i indywidualnej (por. Wach 2013) - coraz większego znaczenia nabiera ostatnia z wymienionych. Chodzi tutaj głównie o pobudzanie efektuacyjnego sposobu myślenia i działania (Kurczewska 2012), krzewienie otwartej i kolaboracyjnej kultury biznesu oraz wskazywanie korzyści z aktywnego uczestnictwa w społecznościach biznesowych (Skala 2018). Wobec deficytu tych tematów w ramach edukacji formalnej coraz częściej źródłem wiedzy dla przedsiębiorców jest edukacja nieformalna. Andrzej Koźmiński (2011) zauważył, że przedsiębiorczość jest w polskich szkołach utożsamiana przeważnie z drobną wytwórczością (na przykład rzemiosłem) i rodzinnym, nieskomplikowanym biznesem, co eliminuje z programów nauczania elementy myślenia kreatywnego i nieszablonowego (out of the box thinking). Tymczasem to, czego należy nauczać, to twórcza przedsiębiorczość intelektualna i wewnętrzna przedsiębiorczość korporacyjna (intrapreneurship). Plany z tym związane są na szczęście widoczne $w$ treściach nauczania w nowej podstawie programowej kształcenia ogólnego dla liceum ogólnokształcącego i technikum, w których jest mowa o start-upach i innowacyjnych modelach biznesowych ${ }^{4}$.

\section{Metody i formy kształcenia}

Przywoływany wcześniej Andreas Kuckertz (2013) akcentuje dwa elementy, które powinny znajdować się w programach nauczania innowacyjnej przedsiębiorczości: dostarczanie wzorców przedsiębiorców, z którymi adepci mogą się identyfikować (case studies lub spotkania z przedsiębiorcami) oraz nauczanie metodą projektową (project based learning, learning by doing) lub odbywanie staży w start-upach. Podobnie Krzysztof Wach (2013) zwraca uwagę, że program nauczania przedsiębiorczości powinien zawierać takie elementy, jak rozwijanie cech i umiejętności przedsiębiorczych oraz realizowanie projektów biznesowych. Jeff Vanevenhoven (2013), idzie jeszcze dalej i postuluje "wyjście nauczycieli zza biurek, a uczniów z klas". Poza przekazaniem podstawowej wiedzy kształcenie na rzecz innowacyjnej przedsiębiorczości powinno kształtować komplementarne dla wiedzy umiejętności, w tym zwłaszcza efektywną pracę zespołową.

4. Rozporządzenie Ministra Edukacji Narodowej z dnia 30 stycznia 2018 r. w sprawie podstawy programowej kształcenia ogólnego dla liceum ogólnokształcącego, technikum oraz branżowej szkoły II stopnia (Dz.U. 2018, poz. 467). 
Szczupłe ramy niniejszego opracowania nie pozwalają na szerokie omówienie wielu metod i form kształcenia w zakresie innowacyjnej przedsiębiorczości. Dlatego uwaga zostanie skoncentrowana na trzech najważniejszych zagadnieniach $w$ tym zakresie:

$\rightarrow$ formie zajęć,

$\rightarrow$ kompetencjach prowadzącego,

$\rightarrow$ osadzeniu zajęć w ekosystemie przedsiębiorczości.

\section{Forma zajęć}

W wypadku innowacyjnej przedsiębiorczości dobrze się sprawdza zbudowanie procesu kształcenia wokół pracy projektowej w grupach (najlepiej dwu- lub trzyosobowych). W uproszczeniu proces ten składa się z trzech głównych elementów (Rys. 1):

$\rightarrow$ opracowania idei projektu w formule: „Kto jest klientem (użytkownikiem)?", "Jaki ma problem?", "Jakie proponujemy rozwiązanie?",

$\rightarrow$ weryfikacji projektu przy użyciu odpowiedniego zestawu narzędzi, głównie modelowania biznesowego,

$\rightarrow$ prezentacji końcowej projektu.

Rysunek 1. Główne etapy rozwoju projektu przedsiębiorczości innowacyjnej w procesie kształcenia

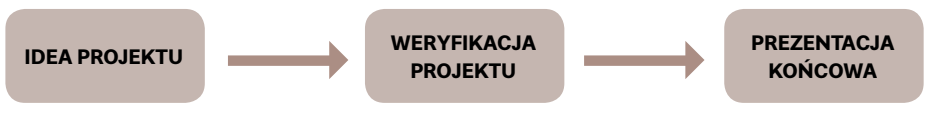

Źródło: Opracowanie własne.

Każdy element tej triady jest równie ważny. Często popełniany błąd (zarówno przez studentów, jak i przez prowadzących) polega na nadmiernym przywiązywaniu wagi do samego pomysłu na projekt jako elementu decydującego o całym jego potencjale i o ocenie pracy studentów podczas semestru. Pomysł na projekt powinien również spełniać pewne warunki, aby móc być uznany za innowacyjny: musi zawierać w sobie element nowości i nie może powielać pospolitych lub typowych modeli biznesowych (na przykład tanio kupił - drożej sprzedał), być franszyzą lub przedstawicielstwem innej firmy. 
$\mathrm{Na}$ każdym etapie kształcenia realizowanego $w$ formule projektowej można wyróżnić elementy: przekazywania wiedzy, doskonalenia umiejętności i kształtowania postaw proprzedsiębiorczych (Tab. 1). Na etapie formułowania idei projektu (ok. 20 proc. czasu przeznaczonego na zajęcia - w trakcie zarówno spotkań, jak i pracy samodzielnej studenta) w ramach form wykładowych należy pomóc studentom odnaleźć interesującą ich tematykę projektu: omówić case studies, wskazać bazy danych, w których mogą znaleźć inspirację, dowiedzieć się, co w interesujących ich obszarach rozwijają realni przedsiębiorcy (na przykład baza Crunchbase, strona internetowa angel.co, baza na stronie fundacji Startup Poland). Warto sięgnąć po aktualizowane co pół roku opracowanie najciekawszych obszarów powstawania nowych rozwiązań biznesowych, przygotowane przez YCombinator, jeden z najlepszych akceleratorów młodych biznesów z Doliny Krzemowej (www.ycombinator.com/rfs). Warsztaty na tym etapie pracy polegają głównie na omawianiu i dopracowywaniu pomysłów, z elementami twórczego rozwiązywania problemów (design thinking) i ćwiczenia myślenia efektuacyjnego (por. Sarasvathy 2008). Rezultatem pracy jest koncepcja projektów w formule: klient - problem - rozwiązanie oraz uformowanie zespołów projektowych. 
Tabela 1. Metody i formy kształcenia na różnych etapach rozwoju projektu przedsiębiorczości innowacyjnej

\begin{tabular}{|c|c|c|c|}
\hline $\begin{array}{l}\text { ETAP PROJEKTU } \\
\text { / FORMA } \\
\text { KSZTAKCENIA }\end{array}$ & IDEA PROJEKTU & WERYFIKACJA PROJEKTU & $\begin{array}{l}\text { PREZENTACJA } \\
\text { KOŃCOWA }\end{array}$ \\
\hline $\begin{array}{l}\text { WYKKADY } \\
\text { (WIEDZA) }\end{array}$ & $\begin{array}{l}\text { inspiracje, case } \\
\text { studies, inwentyka, } \\
\text { efektuacja }\end{array}$ & $\begin{array}{l}\text { modelowanie biznesowe, odkrywa- } \\
\text { nie klienta } \rightarrow \text { wywiady, analiza ryn- } \\
\text { ku i konkurencji, analiza zasobów, } \\
\text { strategie marketingowe, idea MVP, } \\
\text { monetyzacja }\end{array}$ & $\begin{array}{l}\text { formuła DemoDay, } \\
\text { sztuka prezentacji, } \\
\text { struktura i forma } \\
\text { prezentacji }\end{array}$ \\
\hline $\begin{array}{l}\text { WARSZTATY } \\
\text { (UMIEJĘTNOŚCI) }\end{array}$ & $\begin{array}{l}\text { design thinking, } \\
\text { budowanie zespo- } \\
\text { łu (team building) }\end{array}$ & $\begin{array}{l}\text { modelowanie biznesowe } \rightarrow \\
\text { stawianie hipotez, projektowanie } \\
\text { wywiadów, budowanie strategii } \\
\text { marketingowej, budowanie modeli } \\
\text { przychodowych, planowanie i reali- } \\
\text { zacja działań }\end{array}$ & $\begin{array}{l}\text { struktura i forma } \\
\text { prezentacji - przy- } \\
\text { gotowanie i próby }\end{array}$ \\
\hline $\begin{array}{c}\text { PRACA } \\
\text { PROJEKTOWA } \\
\text { (UMIEJĘTNOŚCI) }\end{array}$ & $\begin{array}{l}\text { pomysły projek- } \\
\text { towe w konwencji: } \\
\text { klient } \rightarrow \text { problem } \rightarrow \\
\text { rozwiązanie }\end{array}$ & $\begin{array}{l}\text { budowanie modeli biznesowych } \\
\text { i ich weryfikacja, przeprowadzenie } \\
\text { wywiadów, prototypowanie (MVP) }\end{array}$ & $\begin{array}{l}\text { przygotowanie } \\
\text { prezentacji }\end{array}$ \\
\hline $\begin{array}{l}\text { WEJŚCIE } \\
\text { W EKOSYSTEM } \\
\text { PRZEDSIĘBIOR- } \\
\text { CZOŚCI (POSTAWY } \\
\text { PROPRZEDSIĘ- }\end{array}$ & \multicolumn{2}{|l|}{ mentoring } & $\begin{array}{l}\text { publiczność na } \\
\text { DemoDay: przed- } \\
\text { siębiorcy, inwe- } \\
\text { storzy, członkowie } \\
\text { społeczności }\end{array}$ \\
\hline BIORCZE) & \multicolumn{3}{|c|}{$\begin{array}{l}\text { uczestniczenie w spotkaniach społeczności przedsiębiorczych: konferencje, } \\
\text { spotkania, hackatony itp. }\end{array}$} \\
\hline
\end{tabular}

Źródło: Opracowanie własne.

Etap weryfikacji projektu stanowi główną treść zajęć, jest więc najobszerniejszy (ok. 60 proc. czasu przeznaczonego na zajęcia). Kluczowe elementy to oczywiście modelowanie biznesowe ( $w$ tym budowanie modeli przychodowych - "monetyzacja projektu"), przeprowadzenie wywiadów z potencjalnymi klientami i- ewentualnie - prototypowanie (w miarę możliwości). Chodzi tutaj zarówno o przekazanie niezbędnej wiedzy w tym zakresie, jak i o zrealizowanie praktycznych warsztatów na zajęciach oraz równoległą pracę studentów poza zajęciami (na przykład przeprowadzenie wywiadów).

Jednym z ważnych wyzwań na tym etapie zajęć z przedsiębiorczości innowacyjnej jest zastąpienie tradycyjnego narzędzia - biznesplanu - bardziej adekwatnym instrumentem, czyli modelowaniem biznesowym. W odniesieniu do przedsięwzięć innowacyjnych, zwłaszcza rozwijanych na 
rynkach, na których produkty lub usługi mają charakter niematerialny (na przykład wirtualny), biznesplan po prostu nie sprawdza się jako metoda organizacji pracy i zarządzania przedsięwzięciem (por. Blank 2013, Sommer, Loch, Dong 2009, Lange i in. 2007). Przedsiębiorca rozpoczyna działalność w warunkach tak wysokiej niepewności, że trafne przewidywanie zdarzeń i szacowanie głównych parametrów biznesu (przychodów, kosztów, wielkości sprzedaży i niezbędnych zasobów) przeważnie nie prowadzi do oczekiwanych rezultatów, czyli do obniżenia ryzyka przedsięwzięcia (por. Tanev 2017, Picken, 2017). Modelowanie biznesowe i-szerzej - metodyka zarządzania Lean Startup dostarczają tutaj lepszych od biznesplanu narzędzi rozwijania pomysłu w innowacyjny biznes (por. Skala 2018).

Ważnym elementem kształcenia w zakresie innowacyjnej przedsiębiorczości jest również zderzenie idei projektów rozwijanych przez studentów z realną opinią ich potencjalnych klientów, realizowana przez zaprojektowanie, przeprowadzenie i analizę wywiadów bezpośrednich, które potwierdzają główne hipotezy postawione na etapie modelowania biznesowego i (lub) pracy nad propozycją wartości, albo im zaprzeczają. Warto i na tym etapie podkreślać znaczenie myślenia efektuacyjnego (Sarasvathy 2008), które w budowaniu przedsięwzięć innowacyjnych sprawdza się lepiej niż myślenie przyczynowo-skutkowe. Na każdym etapie rozwoju projektu można ćwiczyć efektuacyjne sposoby myślenia, planując i realizując działania wyznaczane bardziej w funkcji dostępnych w danej chwili (zazwyczaj skromnych) zasobów niż dalekosiężnych, trudno osiągalnych celów.

Ostatni etap zajęć to przygotowanie do prezentacji końcowych rezultatów pracy studentów nad projektem ( 20 proc. dostępnego czasu). Doświadczenie wskazuje, że świadomość przybycia gości z praktyki biznesowej bardzo mobilizuje studentów na tym etapie. Warto zadbać, aby zasady przekazywania konstruktywnej krytyki projektów były jasno ustalone zarówno ze studentami, jak i z zaproszonymi gośćmi. $\mathrm{Na}$ uczelni wśród gości powinien się znaleźć ktoś z centrum transferu technologii lub z inkubatora przedsiębiorczości z realną ofertą wsparcia ze strony uczelni dla najlepszych zespołów.

\section{Kompetencje prowadzącego i osadzenie w ekosystemie przedsiębiorczości}

Kompetencje edukatora w zakresie innowacyjnej przedsiębiorczości są ważnym elementem procesu kształcenia. Sandra Waddock i Josep 
Lozano (2013) zwrócili uwagę na ten problem, stwierdzając, że potrzebne są badania nie tylko nad tym, jak najlepiej przygotować uczniów do przedsiębiorczej ścieżki rozwoju zawodowego, ale także nad właściwym wykształceniem kadr prowadzących zajęcia nowego typu. Wymagają one bowiem umiejętności, których nabycie jest czasochłonne i trudne do opanowania, zwłaszcza dla kadry uniwersyteckiej, która jest przeważnie bardziej skoncentrowana na działalności naukowej niż edukacyjnej, zwłaszcza zaś biznesowej. Sposobem na uzupełnienie tych braków jest właśnie wniknięcie w lokalny ekosystem przedsiębiorczości - zarówno prowadzących zajęcia, jak i słuchaczy. Ekosystemu nie tworzą sami przedsiębiorcy, lecz również inni ważni uczestnicy przedsiębiorczej społeczności: fundusze inwestycyjne, wyspecjalizowane instytucje państwowe, jednostki badawczo-rozwojowe, media branżowe, liderzy społeczności, korporacje, kancelarie prawne.

Prowadzący zajęcia powinien na tyle dobrze znać lokalny ekosystem przedsiębiorczości, aby zapewnić wizyty gości, zwłaszcza przedsiębiorców, a także zorganizować co najmniej jedną sesję mentoringową dla uczestników zajęć. Mentoring, jako najbardziej ceniony przez samych przedsiębiorców sposób pozyskiwania wiedzy i innych zasobów, na przykład cennych kontaktów biznesowych (Beauchamps, Krysztofiak-Szopa, Skala 2018, Beauchamps, Kowalczyk, Skala 2017), powinien być stałym elementem curriculum zajęć. W ten sposób uczestnicy mogą się przekonać o wartości mentoringu oraz nabyć zwyczaju korzystania z tej formy wsparcia.

Studenci powinni być także zobligowani do wzięcia udziału w kilku spotkaniach społeczności przedsiębiorców w czasie trwania semestru projektowego - poza uczelnią.

\section{Zakończenie}

Przedsiębiorczość innowacyjna stanowi tę część aktywności biznesowej, która wywiera spory w stosunku do swojej niewielkiej skali wpływ na rozwój ekonomiczno-społeczny. Wpływ ten przejawia się przez aplikację i komercjalizację postępu technicznego, generowanie nadwyżek finansowych i wpływów podatkowych oraz tworzenie nowych, trwałych i dobrych jakościowo miejsc pracy. Kształcenie na rzecz rozwoju przedsiębiorczości innowacyjnej jest krytycznie ważne dla właściwego funkcjonowania i pobudzania tej formy aktywności człowieka, przejawiającej się zarówno w zakładaniu nowych przedsięwzięć innowacyjnych (tak 
zwanych start-upów), jak i wykształcaniu proaktywnych i twórczych postaw wśród pracowników istniejących przedsiębiorstw.

Skuteczne kształcenie $w$ tym zakresie wymaga z jednej strony nabycia specjalistycznej wiedzy i kompetencji przez edukatorów prowadzących tego typu zajęcia w ramach formalnego i pozaformalnego systemu edukacji, z drugiej zaś - wysokiego zaangażowania słuchaczy (uczniów, studentów, przedsiębiorców), świadomych znaczenia nabywanych kompetencji i umiejętności dla ich rozwoju zawodowego. Dążenie do bliższego powiązania systemu edukacji (na każdym jego poziomie) z rynkiem pracy i osiągnięcia strategicznego celu, jakim jest wyraźne podniesienie poziomu innowacyjności polskiej gospodarki, powinno jak najszybciej znaleźć odbicie w popularyzacji kształcenia na rzecz innowacyjnej przedsiębiorczości w polskich szkołach i na uniwersytetach. 


\section{Bibliografia}

$\rightarrow$ Andrews, D., Criscuolo C., Menon, C. (2014), Do resources ow to patenting firms? Cross-country evidence from firm level data, OECD Economic Department Working Papers, 1127.

$\rightarrow$ Baumol, W.J. (2010), The Microtheory of the Innovative Entrepreneur, Princeton, NJ, Oxford, UK: Princeton University Press.

$\rightarrow$ Beauchamp, M., Kowalczyk, A., Skala, A. (2017), Polskie Startupy. Raport 2017, Warszawa: Startup Poland.

$\rightarrow$ Beauchamp, M., Krysztofiak-Szopa, J., Skala, A. (2018), Polskie Startupy. Raport 2018, Warszawa: Startup Poland.

$\rightarrow$ Birch, D.L. (1979), The Job Generation Process, MIT program on neighborhood and regional change, Cambridge, MA.

$\rightarrow$ Birch, D.L. (1987), Job Creation in America: How Our Smallest Companies Put the Most People to Work, New York: The Free Press.

$\rightarrow$ Blanchenay, P.F., Calvino, C., Criscuolo, C., Menon, C. (2017), Cross-country Evidence on Business Dynamics over the Last Decade: From Boom to Gloom?, OECD Science, Technology and Industry, Working Paper.

$\rightarrow$ Blank, S. (2013), Why the lean start-up changes everything , "Harvard Business Review", 91 (5), s. 63-72.

$\rightarrow$ Block, J.H., Fisch, C.O., van Praag, M. (2017), The Schumpeterian entrepreneur: a review of the empirical evidence on the antecedents, behavior and consequences of innovative entrepreneurship, „Industry and Innovation”, 24 (1), s. 61-95.

$\rightarrow$ Calvino, F.C., Criscuolo, C., Menon, C. (2016), No Country for Young Firms? Start-up Dynamics and National Policies, „OECD Science, Technology and Industry Policy Papers", 29, Paris: OECD Publishing.

$\rightarrow$ Cieślik, J. (2014), Przedsiębiorczość, polityka, rozwój, Warszawa: Wydawnictwo Akademickie Sedno. 
$\rightarrow$ Coad, A., Daunfeldt, S.O., Hölzl, W., Johansson, D., Nightingale, P. (2014), High-growth firms: introduction to the special section, "Industrial and Corporate Change", 23 (1), s. 91-112.

$\rightarrow$ Criscuolo, C., Gal, P.N., Menon, C. (2014), The Dynamics of Employment Growth: New Evidence from 18 Countries, „OECD Science, Technology and Industry Policy Papers", 14, Paris: OECD Publishing.

$\rightarrow$ Decker, R.A., Haltiwanger, J., Jarmin, R.S., Miranda, J. (2016), Where has all the skewness gone? The decline in high-growth (young) firms in the US, „European Economic Review", 86, s. 4-23.

$\rightarrow$ Drucker, P.F. (1992), The new society of organizations, „Harvard Business Review".

$\rightarrow$ Fairlie, R.W., Kapur, K., Gates, S. (2011), Is Employer-based Health Insurance a Barrier to Entrepreneurship?, "Journal of Health Economics”, 30 (1), s. 146-162 .

$\rightarrow$ Fayolle, A., Lassas-Clerc, N. (2006), Essay on the nature of entrepreneurship education, International Conference Entrepreneurship in United Europe-Challenges and Opportunities.

$\rightarrow$ Guzman, J., Stern, S. (2016), The State of American Entrepreneurship: New Estimates of the Quantityand Quality of Entrepreneurship for 15 US States, 1988-2014, National Bureau of Economic Research, Working Paper, 22095.

$\rightarrow$ Haltiwanger, J., Jarmin, R.S., Miranda, J. (2013), Who creates jobs? Small versus large versus young, „Review of Economics and Statistics”, 95 (2), s. 347-361.

$\rightarrow$ Henry, C., Hill, F., Leitch, C. (2005a), Entrepreneurship education and training: can entrepreneurship be taught?, cz. 1, „Education + Training”, 47 (2), s. 98-111.

$\rightarrow$ Henry, C., Hill, F., Leitch, C. (2005b), Entrepreneurship education and training: can entrepreneurship be taught?, cz. 2, „Education + Training”, 47 (3), s. 158169.

$\rightarrow$ Kirby, D.A. (2004), Entrepreneurship education: can business schools meet the challenge?, „Education + Training", 46 (8/9), s. 510-519.

$\rightarrow$ Koźmiński, A.K. (2011), The new revolution in management education?, „Master of Business Administration", 19 (4), s. 2-6.

$\rightarrow$ Kösters, S. (2010), Subsidizing Start-ups: Policy Targeting and Policy Effectiveness, „Journal of Industry, Competition and Trade”, 10 (3-4), s. 199-225.

$\rightarrow$ Kuckertz, A. (2013), What's Hot in Entrepreneurship Research in 2013?, The 1st of a Series of Annual Trend Surveys, Hohenheim: Universität Hohenheim.

$\rightarrow$ Kuckertz, A., Prochotta, A. (2018), What's Hot in Entrepreneurship Research in 2018?, Hohenheim Entrepreneurship Research Brief, Hohenheim: Universität Hohenheim. 
$\rightarrow$ Kuratko, D.F. (2005), The emergence of entrepreneurship education: Development, trends, and challenges, „Entrepreneurship Theory and Practice”, 29 (5), s. 577-598.

$\rightarrow$ Lange, J.E., Mollov, A., Pearlmutter, M., Singh, S., Bygrave, W.D. (2007), Pre-star$t$-up formal business plans and post-start-up performance: $A$ study of 116 new ventures, „Venture Capital”, 9 (4), s. 237-256.

$\rightarrow$ Matlay, H. (2005), Entrepreneurship education in UK business schools: Conceptual, contextual and policy considerations, „Journal of Small Business and Enterprise Development", 12 (4), s. 627-643.

$\rightarrow$ McKeown, J., Millman, C., Reddy Sursani, S., Smith, K., Martin, L.M. (2006), Graduate entrepreneurship education in the United Kingdom, "Education + Training", 48 (8/9), s. 597-613.

$\rightarrow$ McMullan, W.E., Long, W.A. (1987), Entrepreneurship education in the nineties, "Journal of Business Venturing", 2 (3), s. 261-275.

$\rightarrow$ Mwasalwiba, E.S. (2010), Entrepreneurship education: a review of its objectives, teaching methods, and impact indicators, „Education + Training”, 52 (1), s. 20-47.

$\rightarrow$ Picken, J.C. (2017), From startup to scalable enterprise: Laying the foundation, „Business Horizons”, 60 (5), s. 587-595.

$\rightarrow$ Pittaway, L., Cope, J. (2007), Entrepreneurship education: a systematic review of the evidence, „International Small Business Journal”, 25 (5), s. 479-510.

$\rightarrow$ Rannikko, H., Autio, E. (2016), Retaining Winners: Can Policy Boost High-growth Entrepreneurship?, „Research Policy”, 45 (1), s. 42-55.

$\rightarrow$ Sarasvathy, S. (2008), Effectuation: elements of entrepreneurial expertise, Northampton: Edward Elgar Publishing.

$\rightarrow$ Schoar, A. (2010), The divide between subsistence and transformational entrepreneurship, „Innovation Policy and the Economy, 10 (1), s. 57-81.

$\rightarrow$ Schumpeter, J. (1942), Capitalism, Socialism and Democracy, New York: Harper \& Brothers.

$\rightarrow$ Shane, S.A. (2008), The Illusions of Entrepreneurship: The Costly Myths that Entrepreneurs, Investors and Policy Makers Live By, New Haven: Yale University Press.

$\rightarrow$ Skala, A. (2016), Badanie efektywności programów edukacyjnych w zakresie przedsiębiorczości na podstawie studium przypadku Politechniki Warszawskiej - komunikat z badań, „Przedsiębiorczość - Edukacja”, 12, s. 364-377.

$\rightarrow$ Skala, A. (2018), Startupy. Wyzwanie dla zarzq̨dzania i edukacji przedsiębiorczości, Kraków: edu-Libri. 
$\rightarrow$ Sommer, S.C., Loch, C.H., Dong, J. (2009), Managing complexity and unforeseeable uncertainty in startup companies: An empirical study , "Organization Science", 20 (1), s. 118-133.

$\rightarrow$ Stępniak-Kucharska, A. (2015), Rola państwa we wspieraniu działalności badawczo-rozwojowej polskich przedsiębiorstw , "Studia Ekonomiczne”, 209, s. 199-208.

$\rightarrow$ Tanev, S. (2017), Is There a Lean Future for Global Startups?, „Technology Innovation Management Review", 7 (5), s. 6-15.

$\rightarrow$ Vanevenhoven, J. (2013), Advances and challenges in entrepreneurship education, „Journal of Small Business Management", 51 (3), s. 466-470.

$\rightarrow$ Vesper, K.H., Gartner, W.B. (1997), Measuring progress in entrepreneurship education, „Journal of Business Venturing”, 12 (5), s. 403-421.

$\rightarrow$ Wach, K. (2013), Edukacja na rzecz przedsiębiorczości wobec współczesnych wyzwań cywilizacyjno-gospodarczych, „Przedsiębiorczość - Edukacja”, 9, s. 246-257.

$\rightarrow$ Waddock, S., Lozano, J.M. (2013), Developing more holistic management education: Lessons learned from two programs, "Academy of Management Learning \& Education", 12 (2), s. 265-284.

$\rightarrow$ Wong, P., Ho, Y., Autio, E. (2005), Entrepreneurship, innovation and economic growth: Evidence from GEM data, „Small Business Economics”, 24 (3), s. 335-350. 


\section{Netografia}

$\rightarrow$ Charney, A., Libecap, G.D. (2000), The Impact of Entrepreneurship Education: An Evaluation of the Berger Entrepreneurship Program at the University of Arizona, 1985-1999, Final Report, ebr.eller.arizona.edu/sites/ebr/les/docs/research-studies/impact-of-entrepreneurship-education-1985-1999.pdf (dostęp: 9.05.2018).

$\rightarrow$ Cieślik, J. (2018), Samozatrudnieni jako adresaci polityki wspierania przedsiębiorczości i systemu ubezpieczeń społecznych, Alert Centrum Przedsiębiorczości ALK, 11/3, www.cieslik.edu.pl/wp-content/uploads/2018/09/ Alert_11_03.2018_CP_ALK-Samozatrudnieni-jako-adresaci-polityki-wspierania-przedsiębiorczości.pdf (dostęp: 10.11.2018).

$\rightarrow$ Kurczewska, A. (2012), W jaki sposób myślq przedsiębiorcy? - czyli: „jeśli mogę kontrolować przyszłość, nie muszę jej przewidywać", „e-mentor", 5 (47), www.e-mentor.edu.pl/artykul/index/numer/47/id/965 (dostęp: 30.10.2017).

$\rightarrow \mathrm{Ng}$, W., Stuart, T.E. (2016), Of Hobos and Highfliers: Disentangling the Classes and Careers of Technology-Based Entrepreneurs, Working Paper, www.gsb. stanford.edu/sites/gsb/ les/ng_italk2016_0.pdf (dostęp: 20.02.2017).

$\rightarrow$ Rozporządzenie Ministra Edukacji Narodowej z dnia 30 stycznia 2018 r.oku w sprawie podstawy programowej kształcenia ogólnego dla liceum ogólnokształcącego, technikum oraz branżowej szkoły II stopnia (Dz.U. 2018, poz. 467), prawo.sejm.gov.pl/isap.nsf/DocDetails.xsp?id=WDU20180000467 (dostęp 29.11.2018). 


\section{Przedsiębiorczy nauczyciel}

Anna Śliwińska

W tekście podjęto problematykę wyzwań, jakie stają współcześnie przed nauczycielem, a także konieczności stworzenia nowego wizerunku osób odpowiedzialnych za edukację. Wskazano na potrzebę przyjęcia nowych strategii wobec konieczności kształtowania kluczowych kompetencji oraz określono współczesne procesy kulturowe, które kształtują młode pokolenie. Zakładając, że celem szkoły jest przygotowanie ucznia do funkcjonowania w dorosłym życiu, a co za tym idzie - na rynku pracy, położono nacisk na działania, które należy podejmować w pracy dydaktyczno-wychowawczej.

\section{Słowa kluczowe:}

osobowość nauczyciela

cywilizacja informacyjna

kompetencje przyszłości

metody i formy pracy 


\section{Enterprising teacher}

Anna Śliwińska

The chapter describes the challenges faced by the teacher today, as well as the need to create a new image of those responsible for education. The need to adopt new strategies regarding the necessity to shape key competences was pointed out and the contemporary cultural processes that shape the young generation were defined. Assuming that the goal of the school is to prepare the student to functioning in adult life, and thus the labour market, the emphasis is put on the actions to be taken in didactic and educational work.

\section{Keywords:}

the personality of the teacher

civilization of information

competences of the future

methods and forms of work 


\section{Wstęp}

Kreatywność to cecha każdego człowieka, bez względu na wiek, ale musimy pamiętać, że jeżeli stosujemy tylko podające metody nauczania, to zabijamy w uczniach ciekawość i chęć poznania. Na szczęście można te dwie, zdawałoby się, przeciwstawne kategorie połączyć. Można podawać wiedzę i pobudzać ciekawość uczniów, ale należy przemodelować sposób realizacji tego zadania. Ważne, by stawiać przed uczniami problem, by samodzielnie mogli odkrywać i szukać rozwiązań. Wykonanie tego przedsięwzięcia wymaga dużego wysiłku, zaangażowania, wewnętrznej motywacji, pracy nauczyciela - człowieka, który stawia sobie konkretne cele i konsekwentnie je realizuje.

\section{Szkoła dawniej i dzisiaj}

Historia powszechnej edukacji sięga w Polsce XVIII w. Co roku na akademii z okazji 3 Maja dumnie powtarzamy, że to właśnie w Polsce powstało pierwsze na świecie ministerstwo oświaty - Komisja Edukacji Narodowej. Jak wówczas wyglądało szkolnictwo? Jak wygląda współczesna szkoła? Jakie zaszły zmiany? Odpowiedzi na te pytania są bardzo trudne. Gdy się bliżej przyjrzymy, może się okazać, że niewiele uległo zmianie. Nadal jest to budynek, w którym są sale z równo ustawionymi ławkami oraz nauczyciel i uczniowie. Oczywiście uczniowie są inni.

Wcześniej mieliśmy do czynienia z uczniem, który był jak czysta kartka, tabula rasa - nie wiedział nic o otaczającym go świecie, nie rozumiał zachodzących w nim zjawisk. Jedynym miejscem, gdzie mógł się tego dowiedzieć, była szkoła. Jedyną osobą, która mogła go nauczyć, był nauczyciel - mistrz, źródło wszelkiej wiedzy.

Taka sytuacja jest już historią i prawdopodobnie nigdy się nie powtórzy. Tak naprawdę nauczyciel powinien się z tego cieszyć, gdyż może pracować szybciej, wydajniej, efektywniej oraz tworzyć materiały i projekty, o których wiele lat temu nie śmiałby nawet pomarzyć.

Jest jednak pewien problem. Otóż zdecydowana większość nauczycieli nie zdaje sobie z tego sprawy. Wręcz przeciwnie - uważa obecne pokolenie za najgłupsze, pozbawione jakiejkolwiek kultury, wartości, przekonań. Współczesny uczeń należy do pokolenia Y. Nie poznał świata bez internetu, jest organicznie zrośnięty z komputerem. Żyje w świecie wirtualnym i stamtąd czerpie wiedzę. Ignoruje szkołę, bo 
ona za nim nie nadąża. I w ten sposób luka między rzeczywistością a wizją świata przedstawianą w szkole coraz bardziej rośnie.

Uczeń dostaje podręcznik, do którego jest załączona płyta. To szczyt cyfryzacji, osiągnięcie ostatnich lat, duma wydawnictw. Tylko co on ma zrobić z tą płytą? Gdzie ją włożyć, by odsłuchać, zobaczyć? Tak jak dorośli nie wychodzą z domu bez zegarka, tak współczesny uczeń nie rozstaje się z tabletem lub ze smartfonem. Tylko że tam nie ma miejsca na płytę.

W wieku błyskawicznego rozwoju technologii w szkole, w której nauczyciel ma kłopoty z obsługą komputera, a pracownia informatyczna przypomina muzeum, coraz trudniej przekonać ucznia, że nauczyciel to autorytet, a wiedza szkolna pomaga poznawać świat.

Często nauczyciel uczy wiedzy teoretycznej, która nie przystaje do rzeczywistości. Nadal zdarza się, że stosowane są metody werbalne, szerzy się encyklopedyzm. Uczeń ma pamięciowo opanować wiedzę, którą w ciągu kilku sekund potrafi odnaleźć w internecie.

\section{Współczesny nauczyciel}

Jedynym rozwiązaniem w obecnej sytuacji wydaje się przedsiębiorczy nauczyciel. Przedsiębiorczy, to znaczy jaki? Jak podaje Słownik języka polskiego PWN (2019): „chętny do podejmowania różnych spraw i umiejący je pomyślnie załatwić". Wydawałoby się, że to cechy charakteryzujące ludzi biznesu, pracowników marketingu. Nic bardziej mylnego. To teraz niezbędne cechy, by efektywnie pracować w oświacie. Współczesny nauczyciel musi być otwarty nie tylko na potrzeby młodego pokolenia, lecz także na zmiany zachodzące w świecie. A są to zmiany galopujące. Tylko człowiek obrotny, zaradny, pomysłowy, kreatywny jest w stanie poradzić sobie z wyzwaniami współczesnej szkoły. To niespokojny duch, ciągle poszukujący nowych rozwiązań, ciekawy świata, powtarzający za Szymborską: "A ja nie wiem i nie wiem i trzymam się tego". Nauczyciel przedsiębiorczy przesunie nacisk z przekazywania wiedzy na nauczanie umiejętności, ponieważ doskonale zdaje sobie sprawę z tego, że we współczesnym świecie wiedza jest na wyciągnięcie ręki, a największy problem polega na tym, by umieć z niej korzystać, by rozumieć to, co czytamy, widzimy, słyszymy. Zadanie współczesnego nauczyciela jest znacznie trudniejsze - musi przede wszystkim nauczyć ucznia myślenia, argumentowania, podejmowania decyzji, brania 
na siebie odpowiedzialności; musi wykształcić człowieka przedsiębiorczego. A to robić może tylko człowiek przedsiębiorczy.

\section{Jak pracować ze współczesnym uczniem?}

Musimy zmienić fundamentalne zasady, na których opieramy edukację naszych dzieci. Naszym zadaniem jest nauczenie ich, jak stawiać czoło przyszłości. Konieczna jest zmiana paradygmatu edukacji. Konieczne jest przyjęcie innej postawy wobec uczniów. Nauczyciel nie ma być źródłem wiedzy - czasy renesansu minęły - musi on stać się osobą przedsiębiorczą, o silnych cechach charakteru, pełną zapału i entuzjazmu.

Współcześni młodzi ludzie są zorientowani na pracę zespołową, nastawieni na zmiany i innowacyjność, na wykorzystywanie narzędzi cyfrowych. Warto pokazać im, że za pomocą tego, co znają najlepiej i lubią, mogą wiele się nauczyć. Docenią i zaakceptują jedynie to, co uznają za przydatne, a tym samym interesujące.

Szansą dla współczesnych uczniów są przedsiębiorczy nauczyciele, którzy przekażą im praktyczną wiedzę. Wskażą, dlaczego warto się uczyć i jak można w praktyce zastosować pozyskaną wiedzę i nabyte umiejętności. Docenią kreatywność i otwartość młodego pokolenia na zmiany.

Jak poprowadzić lekcję, by uczniowie się nie nudzili? Co zrobić, by uczestnictwo w lekcji nie było przykrym obowiązkiem?

Szkoły przyzwyczaiły nas do tego, że rzadko są innowacyjne i twórcze. Zadaniem nauczyciela jest przekazanie informacji, a uczeń musi przyswajać mnóstwo reguł i definicji. Prezentowanie materiału w sposób odtwórczy - polegający na tym, że nauczyciel staje przed klasą i przekazuje wiedzę w formie wykładu - to metoda może i sprawdzona, ale najczęściej nudna.

Nauczyciel przekonany, że jego rola polega na przekazywaniu wiedzy, mówi, dyktuje, czasem tłumaczy. A uczniowie słuchają albo udają, że słuchają. Tak naprawdę piekielnie się nudzą. A przecież nudna lekcja to lekcja stracona. Trudno zmobilizować umysł do jakiejkolwiek aktywności, gdy informacje są przekazywane w sposób mało interesujący.

\section{Jak można temu zapobiec?}

Najprostszym rozwiązaniem jest wykorzystanie na zajęciach multimediów. Współczesny świat jest pełen różnorodnych atrakcji, dlatego uczniowie potrzebują ciągle nowych bodźców, by móc skupić uwagę. 
Nauczyciel musi być aktywny, wchodzić z uczniami w interakcję, dzięki czemu może wzbudzić ich zainteresowanie.

\section{Zadaniem szkoły jest kształcenie logicznie myślących i kreatywnych ludzi. Jak tego dokonać?}

Najprostszą metodą jest zaktywizowanie uczniów i postawienie przed nimi problemów, które mają rozwiązać. I to zadanie znacznie trudniejsze dla nauczyciela niż poprowadzenie wykładu. Trzeba przecież nie tylko doskonale znać materiał, nad którym będą pracowali uczniowie, lecz także sformułować problem, wymyślić zadania dla uczniów i co najważniejsze - stymulować pracę tak, by nie przejąć inicjatywy, ale mieć pełen ogląd sytuacji.

\section{Jakie formy pracy stosować?}

Formą pracy, która bardzo dobrze sprawdza się w warunkach szkolnych, jest praca w grupach. Praca zespołowa pozwala na wprowadzenie podziału obowiązków i uczy odpowiedzialności. W grupie można szybciej i efektywniej zrealizować zadania, które wymagałyby od jednostki ogromnego nakładu pracy. To doskonała okazja do zdobycia dodatkowych kompetencji, dzielenia się wiedzą oraz rozwoju społecznego. Wszyscy doskonale wiemy, że współczesny świat wymaga od pracownika umiejętności współpracy, że wielkie projekty realizuje się w grupach, że praca w korporacjach to praca zespołowa. Takie właśnie kompetencje musi kształcić szkoła i nauczyciel musi mieć tego świadomość.

Pozostaje pytanie, jak dobierać uczniów w grupy. Istnieją różne sposoby, każdy ma swoje wady i zalety.

Pierwszy - najprostszy - polega na tym, że łączymy w grupy uczniów, którzy siedzą blisko siebie.

Zalety: podział następuje sprawnie, cicho, uczniowie są prawie natychmiast gotowi do pracy.

Wady: uczniowie najczęściej pracują w tych samych zespołach.

Drugi - bardziej skomplikowany - wymaga podziału uczniów według wybranego kryterium przed przydziałem do grup.

Zalety: uczniowie pracują w różnych grupach, poznają się wzajemnie i rozwijają różnorodne kompetencje.

Wady: w klasie powstaje chaos, uczniowie przemieszczają się (nie wszyscy od razu orientują się, gdzie mają usiąść), panują hałas, zamieszanie, które jest pretekstem do rozmów. 
Trzeci sposób wymaga wcześniejszego przygotowania sali.

Zalety: uczniowie pracują w losowo wybranych zespołach, przydział do grup odbywa się $w$ fazie organizacyjnej lekcji, najczęściej poszukiwanie miejsca przebiega sprawnie i budzi zainteresowanie.

Wady: należy poświęcić dodatkowy czas, by przygotować salę, losy, uczniowie od razu siadają w grupach, a tym samym zajmują miejsca tyłem do nauczyciela i nie zawsze uważnie słuchają instrukcji.

Niestety praca w grupach nie zawsze przebiega tak, jak byśmy sobie tego życzyli. Efekty pracy w dużej mierze zależą od motywacji.

Pracujmy z uczniami aktywnie, mobilizujmy ich do działania, przełamujmy bariery bierności.

Pomóżmy uczniom uwolnić wrodzony potencjał, by umieli pokonywać trudności, nie tylko te szkolne.

\section{Motywacja do działania}

Tylko zmotywowany nauczyciel może zmotywować uczniów do działania. Jego pracowitość, aktywność, kreatywność w codziennych interakcjach z uczniami przekładają się na ich stosunek do nauki, a tym samym efekty. Nauczyciel w szkole może spotkać się z różnym stopniem zainteresowania uczniów prowadzonymi przez siebie zajęciami. Istnieje wiele sposobów, by zmobilizować ich do aktywnego udziału w lekcji. Jednak nie ma uniwersalnej metody, która pozwoli na zmotywowanie całej klasy. Każdy uczeń jest inny i wymaga indywidualnego podejścia. Znalezienie tego, co go motywuje, pomoże odnieść sukces zarówno nauczycielowi, jak i uczniowi.

Istnieją różnorodne typy zachowań uczniów:

$\rightarrow$ uczeń o słabej motywacji,

$\rightarrow$ uczeń niezainteresowany,

$\rightarrow$ uczeń ciekawy intelektualnie,

$\rightarrow$ uczeń lubiący się bawić,

$\rightarrow$ uczeń niezależny.

Zaklasyfikowanie ucznia do danego typu pozwoli nauczycielowi dobrać odpowiednie sposoby motywacji. Tylko zmotywowany uczeń może odnosić sukcesy.

\section{Uczeń o słabej motywacji}

Uczeń o słabej motywacji ma niskie poczucie własnej wartości. Łączy się ono z niechęcią do nauki i podejmowania działań. Bojąc się 
niepowodzenia, przestaje dostrzegać sens nauki. Zawstydzanie, wyśmiewanie, krytykowanie wpływają na niego destrukcyjnie. Wycofa się i nie podejmie żadnej aktywności. Trzeba uświadomić mu jego zalety, dostrzec starania oraz poświęcić mu uwagę. Aby zmotywować tego ucznia, należy wzbudzić w nim poczucie, że on również potrafi zrobić coś dobrze. Stwarzając przyjazną atmosferę na zajęciach i okazując zainteresowanie, mamy szanse zdobyć zaufanie ucznia, a tym samym zmotywować go do działania.

Pracując z uczniem o słabej motywacji:

$\rightarrow$ pozwól mu pracować w grupie,

$\rightarrow$ powierzaj mu zadania na miarę jego możliwości,

$\rightarrow$ wykorzystuj pomoce, dzięki którym lepiej zrozumie problem,

$\rightarrow$ doceniaj jego starania.

\section{Uczeń niezainteresowany}

Uczeń niezainteresowany często uważa się za osobę niezdolną, nie odrabia zadań domowych, nie angażuje się na lekcjach. Często ma duże zaległości, a w związku z tym kłopoty z przyswojeniem nowych treści. Dodatkowo odczuwa blokadę związaną z lękiem przed rodzicami, nauczycielem, negatywną oceną. Zawstydzanie, wyśmiewanie, krytykowanie wpływają na niego destrukcyjnie. Albo się wycofa, albo przyjmie postawę agresywną. W klasie czuje się onieśmielony, co utrudnia mu przyznanie się do niewiedzy. Aby zmotywować takiego ucznia, należy stworzyć takie warunki, dzięki którym będzie się czuł bezpiecznie. Jeśli uda nam się stworzyć odpowiednią atmosferę oraz sformułować jasne zasady pracy na zajęciach, wówczas mamy szanse, że taki uczeń uwierzy we własne możliwości i podejmie współpracę.

Pracując z uczniem niezainteresowanym:

$\rightarrow$ powierzaj mu zadania na miarę jego możliwości,

$\rightarrow$ formułuj zadania w taki sposób, by go zaciekawiły,

$\rightarrow$ pozwól mu pracować w jego tempie,

$\rightarrow$ chwal go za działania, a nie tylko za ich efekty,

$\rightarrow$ konstrukcyjnie i precyzyjnie formułuj informację zwrotną.

\section{Uczeń ciekawy intelektualnie}

Uczeń ciekawy intelektualnie nie lubi rutyny, zadań schematycznych. Często zadaje kłopotliwe pytania. Zmuszanie go do wykonywania zadań 
przymusowych powoduje zniechęcenie i często brak aktywności. Ignorowany "zdobywa” klasę przeciwko prowadzącemu. Aby zmotywować takiego ucznia, należy powierzyć mu zadanie niestandardowe. Stwarzając na zajęciach atmosferę pracy, możliwość wprowadzania kreatywnych rozwiązań, mamy szansę, że podejmie wyzwanie i się zaangażuje.

Jeśli pracujesz z uczniem ciekawym intelektualnie:

$\rightarrow$ powierzaj mu zadania wymagające dużego zaangażowania,

$\rightarrow$ steruj jego aktywnością, zadając pytania otwarte,

$\rightarrow$ pozwól mu wymyślać własne zadania i problemy,

$\rightarrow$ zwracaj uwagę na efekty działań,

$\rightarrow$ powierzaj mu odpowiedzialne role $w$ grupie.

\section{Uczeń lubiący się bawić}

Uczeń lubiący się bawić często wchodzi w rolę maskotki grupy, to dusza towarzystwa. Jego zadanie polega na skupieniu na sobie uwagi. Nauka jest na ostatnim miejscu. Zmuszanie go do wykonywania zadań wzbudza w nim niechęć i może powodować niewłaściwe zachowania. Mobilizowany do pracy próbuje obrócić wszystko w żart lub ignoruje nauczyciela. Aby zmotywować takiego ucznia, należy zaangażować go w pracę zespołową. Stwarzając na zajęciach swobodną atmosferę, podkreślając znaczenie i rolę jego osoby, można zmobilizować go do wykonywania zadań.

Jeśli pracujesz z uczniem lubiącym się bawić:

$\rightarrow$ przydzielaj mu zadania, dzięki którym będzie miał możliwość pokazania się,

$\rightarrow$ steruj jego aktywnością, powierzając mu krótkie zadania,

$\rightarrow$ rozliczaj go $z$ efektów $w$ trakcie pracy,

$\rightarrow$ pozwól mu zajmować ważną pozycję w grupie,

$\rightarrow$ precyzyjnie formułuj informację zwrotną.

\section{Uczeń niezależny}

Uczeń niezależny ma często nonszalancki stosunek do nauki, szkołę traktuje jako niemiły obowiązek. Choć nie uważa na lekcjach, często wyrwany do odpowiedzi udziela wyczerpujących wyjaśnień. W szkole się nudzi, a przebywanie w klasie uważa za stratę czasu. Aby zmotywować takiego ucznia, należy odkryć, jakie ma zainteresowania, i do nich dostosować charakter przydzielanych zadań. Stwarzając na zajęciach przestrzeń do rozwiązywania problemów i pogłębiania wiedzy, możemy zmotywować go do bardzo dużego zaangażowania. 
Jeśli pracujesz z uczniem niezależnym:

$\rightarrow$ powierzaj mu zadania nietypowe, trudne,

$\rightarrow$ steruj jego aktywnością, podkreślając, że właśnie on posiada możliwości niezbędne do wykonania danego zadania,

$\rightarrow$ pozwól mu skupić się na zadaniu,

$\rightarrow$ zwracaj uwagę na efekty działań,

$\rightarrow$ daj mu czas i przestrzeń do rozwijania aktywności.

\section{Realizacja przedsięwzięć}

Od pracy w grupie już tylko krok do metody projektów, webquestów. Przedsiębiorczy nauczyciel odda inicjatywę w ręce uczniów, pozwoli im uczyć się na błędach, a proces edukacji będzie jedynie stymulował. Co zrobić, by uczniowie pracujący samodzielnie nie zeszli na manowce? Warto zorganizować spotkania robocze.

Konsultacje, bo o nich tu mowa, to sposób pobudzania uczniów do pracy, ich celem jest zasięgnięcie opinii u specjalisty, udzielenie przez niego rad, wyjaśnienie problemów. Spotkania takie są niezwykle ważne, gdy nauczyciel staje się mentorem uczniów samodzielnie realizujących działania.

Uczniowie, którzy przychodzą na konsultacje, nie zawsze są dobrze przygotowani, najczęściej potrzebują pomocy. Nauczyciel może zetknąć się z różnorodnymi problemami i oczekiwaniami uczniów. Jak sobie z nimi radzić? Przede wszystkim tłumaczyć, wyjaśniać, sugerować możliwości. Najważniejsze, by nie przejąć inicjatywy ani nie pracować za uczniów.

Przykładowe trudności:

$\rightarrow$ brak umiejętności współpracy,

$\rightarrow$ konflikt $z$ liderem,

$\rightarrow$ niechęć do podejmowania wyznaczonych działań,

$\rightarrow$ niezrozumienie potrzeby dokumentowania działań,

$\rightarrow$ niesolidność prowadzonej dokumentacji,

$\rightarrow$ niefrasobliwość.

W trakcie konsultacji nauczyciel powinien:

$\rightarrow$ wprowadzić uczniów w problematykę podejmowanej działalności,

$\rightarrow$ wyjaśnić kluczowe zagadnienia, wskazać możliwe narzędzia przydatne do rozwiązania danego problemu, ewentualnie pomóc w dotarciu do podmiotów zewnętrznych, 
$\rightarrow$ pomóc w sformułowaniu praktycznych celów, co ułatwi zdefiniowanie kierunków działania,

$\rightarrow$ wspomagać uczniów w czasie samodzielnej pracy nad rozwiązaniem problemu,

$\rightarrow$ monitorować ich działania,

$\rightarrow$ odpowiednio motywować uczniów,

$\rightarrow$ udzielać informacji zwrotnej, wskazując, co robią dobrze, a co wymaga jeszcze zastanowienia bądź modyfikacji.

Konsultacje to doskonała metoda poznania uczniów, obserwowania ich zachowań, ale też doskonały sposób na dostrzeżenie problemów, które mogą się pojawić w trakcie realizacji zadania, a tym samym możliwość ich szybkiego rozwiązania.

Niektórzy członkowie zespołu mogą okazać się indywidualistami nielubiącymi współpracować z innymi, nie będą chcieli poświęcać swojego czasu, dzielić się z grupą swoimi pomysłami czy doświadczeniem. $W$ takiej sytuacji nauczyciel powinien zareagować i przydzielić im bardziej samodzielne obowiązki, które nie wymagają ścisłej współpracy. Takim osobom trzeba okazać dodatkowe wsparcie, aby poczuli się ważni i potrzebni oraz mieli widoczny wkład w projekt.

Inny problem to konflikt grupy z liderem. Może się zdarzyć, że w zespole jest kilka silnych osobowości, które chciałyby prowadzić projekt, lub osoba wybrana na lidera nie radzi sobie z zadaniami. Należy pamiętać, że zawsze najważniejsze jest dobro grupy. Warto porozmawiać z zespołem o problemie, ale trzeba pamiętać, że próba rozstrzygnięcia konfliktu w sposób demokratyczny może prowadzić do frustracji i niezadowolenia. Być może rozwiązaniem będą rozmowa i wsparcie udzielone liderowi.

Może się zdarzyć, że członkowie grupy nie podejmą się wykonania wyznaczonych działań. Niechęć może mieć różne przyczyny: brak konkretnych umiejętności, brak przekonania do celowości podejmowania tych działań, alternatywne pomysły. W takiej sytuacji warto wesprzeć lidera i uświadomić członkom zespołu, że przedsięwzięcie zakończy się pomyślnie, jeśli wszystkie działania zostaną zrealizowane. Można zaproponować, by członkowie zespołu samodzielnie podzielili się zadaniami.

Uczniowie często mają niechęć do prowadzenia jakiejkolwiek dokumentacji. Nakaz zbierania dokumentów kojarzy im się z nudnymi notatkami, referatami, ze sprawozdaniami i często zabija chęć dzia- 
łania. Warto porozmawiać wówczas z całym zespołem i wyjaśnić, dlaczego dokumentowanie działań jest takie ważne. Należy uświadomić uczniom, że dzięki tym "papierom" będą mieli na bieżąco informację o stanie realizacji przedsięwzięcia, a w przyszłości cenne źródło informacji. Prowadzenie dokumentacji to pięta achillesowa wielu zespołów. Uczniowie często nie zdają sobie sprawy, jak wiele zależy od jej solidności i rzetelności, szczególnie jeśli problem dotyczy finansów. Warto porozmawiać z zespołem i wyjaśnić zasady opracowania budżetu. Koniecznie trzeba zwrócić uczniom uwagę na to, że każde działanie pociąga za sobą konsekwencje finansowe i nawet przedmioty przyniesione $z$ domu, otrzymane jako darowizna powinny być uwzględnione w kosztach przedsięwzięcia.

Wielokrotnie spotykamy się z przekonaniem, że szkoła doskonale uczy rozwiązywania testów, ale nie przekazuje wiedzy praktycznej, niezbędnej w dorosłym życiu. Warto wyjaśnić uczniom zasady funkcjonowania różnorodnych mechanizmów. Trzeba jednak robić to umiejętnie, aby przekonać ich do podejmowania działań, a nie do nich zniechęcać.

\section{Wnioski i rekomendacje}

Praca przedsiębiorczego nauczyciela po prostu jest przyjemna, wybija z rutyny, nie pozwala na nudę, fascynuje, pozwala odkrywać wszystko na nowo. Zdarza się, że pojawiają się zmęczenie i niepewność. Wszyscy jesteśmy przecież ludźmi, a tym samym mamy prawo do wyrażania wątpliwości i zadawania pytań, czy w dobrym kierunku zmierzamy. Jako rekomendacje wynikające z powyższych rozważań można zaproponować "dekalog przedsiębiorczego nauczyciela":

1. Bądź pozytywnie nastawiony.

2. Stwarzaj szanse na zwycięstwo.

3. Bądź kreatywny.

4. Wyjaśnij, dlaczego uczniowie powinni wykonać powierzone zadanie.

5. Pozwól uczniom pracować w grupach.

6. Pozwól im używać narzędzi cyfrowych.

7. Nie marnuj okazji do pochwał.

8. Zapewnij warunki do eksperymentowania.

9. Modeluj pożądane zachowania.

10. Mów prawdę. 


\section{Bibliografia}

$\rightarrow$ Czechowski, J. (2014), Przedsiębiorczy nauczyciel jako skuteczny wychowawca, [w:] „Horyzonty Wychowania”, t. 13, nr 26.

$\rightarrow$ Sowislok, K., Przedsiębiorczość, innowacyjność-społeczeństwo informacyjne czy: społeczeństwo informacyjne - przedsiębiorczość i innowacyjność? [w:] "Przedsiębiorczość - Edukacja”, t. 5.

$\rightarrow$ Żur, A. (2014), Kształtowanie postaw odpowiedzialności społecznej w nauczaniu przedsiębiorczości [w:] „Przedsiębiorczość - Edukacja”, nr 10.

$\rightarrow$ Marciniak-Kulka, E., Neyman, O., Wysocka, J. (2017), Wspomaganie szkół w kształtowaniu kompetencji: innowacyjność, kreatywność i praca zespołowa uczniów, Warszawa.

$\rightarrow$ Braun, M., Mach, M. (2012), Zdolne dziecko. Pierwsza pomoc, Warszawa.

$\rightarrow$ Gmitrowicz, D., Jędrzejczak, J. (red.) (2013), Od kreatywności do innowacji, Warszawa. 


\section{Netografia}

$\rightarrow$ "Słownik języka polskiego", PWN, sjp.pwn.pl/szukaj/przedsi\%C4\%99biorczy. html (dostęp: 31.01.2019). 


\section{Wpływ zagranicznych mobilności edukacyjnych na rozwój \\ postaw przedsiębiorczych}

Mateusz Jeżowski, Michał Pachocki, Agnieszka Rybińska

W rozdziale przedstawione zostały wyniki badań efektów zagranicznych mobilności edukacyjnych w kontekście zdobywania kompetencji i umiejętności, które sprzyjają rozwojowi postaw przedsiębiorczych młodych ludzi. Poprzez realizację swoich celów operacyjnych europejskie programy edukacyjne nie tylko wspierają działania nastawione na rozwój umiejętności zdobywanych w ramach kształcenia formalnego, lecz także pomagają zdobyć wiele kompetencji miękkich i społecznych. Dzięki takiemu wsparciu młodzi ludzie mogą lepiej funkcjonować w społeczeństwie oraz łatwiej odnaleźć się na współczesnym rynku pracy.

\section{Słowa kluczowe:}

\section{mobilność}

postawy przedsiębiorcze

kompetencje kluczowe

europejskie projekty edukacyjne

program Erasmus+ 


\section{Impact of foreign educational \\ mobility on the development of \\ entrepreneurial attitudes}

Mateusz Jeżowski, Michał Pachocki, Agnieszka Rybińska

The chapter presents the results of research on international mobility projects with regard to acquiring new skills and competences which support the development of entrepreneurial skills of young people. In view of their operational targets, European education programmes support activities aimed at development of skills within the formal education as well as help to acquire various "soft" and social competences. Thanks to this, young people may function better within the society and make an easier entry into the labour market. 


\section{Wstęp}

Dynamika zmian na rynku pracy oznacza nie tylko zmiany na poziomie instytucji pracodawców, zmiany w środowisku pracy oraz te związane z możliwościami wykorzystania kapitału ludzkiego na rzecz lepszego rozwoju przedsiębiorstw. Naturalną konsekwencją tego procesu jest również zmiana ścieżek zawodowych oraz przejście do otwartego modelu kariery, który charakteryzuje się zdecydowanie większą elastycznością, związaną ze zmianami zawodu, pracodawcy oraz miejsca zamieszkania (Górniak i in. 2015). W kontekście powyższych wyzwań istotnego znaczenia nabiera także koncepcja uczenia się przez całe życie, która od lat 70. ub. w. na stałe zagościła w dyskusjach o jakości systemów edukacyjnych w Europie. Jednym z kluczowych elementów Strategii lizbońskiej, ogłoszonej przez UE w 2000 r., było oparcie dalszego rozwoju gospodarczego i konkurencyjności Europy na edukacji, rozumianej nie tylko jako realizacja formalnego kształcenia na poziomie instytucji, lecz także w wymiarze całożyciowego przyswajania wiedzy, w tym umiejętności podstawowych, przez osoby uczące się, bez względu na ich wiek czy poziom wykształcenia (Komisja Europejska 2000).

Od czasu wprowadzenia Strategii lizbońskiej europejskie polityki edukacyjne opierają się na katalogu ośmiu kompetencji kluczowych, które wskazano w zaleceniu Parlamentu Europejskiego i Rady z 18 grudnia 2006 r., a następnie - w wyniku konsultacji wskazujących na potrzebę zmian - zredefiniowane w Zaleceniu Rady z dnia 22 maja 2018 r. w sprawie kompetencji kluczowych w procesie uczenia się przez całe życie (Fells i in. 2018). Obok takich kompetencji jak umiejętność posługiwania się językiem ojczystym i obcym czy umiejętności matematyczne oraz techniczne wymienia się również kompetencje społeczne, obywatelskie, kompetencje w zakresie świadomości i ekspresji kulturalnej oraz kompetencje w zakresie przedsiębiorczości. O tym, że oprócz kompetencji zawodowych i doświadczenia na rynku pracy istotne są również kompetencje miękkie, świadczą także wyniki badań realizowanych w Polsce (Kocór i in. 2015). I chociaż wiedzę młode osoby wciąż zdobywają przede wszystkim w szkole, to coraz częściej korzystają również ze środków europejskich, biorąc udział w różnego rodzaju projektach o charakterze międzynarodowym.

Przyjmując za T. Rachwałem (2005), że przedsiębiorczość to zespół cech osobowości, takich jak inicjatywność, kreatywność, energia i zapał 
do pracy, wytrwałość w działaniu, a także ciekawość świata, pewność siebie i wiara we własne siły, samodyscyplina, skłonność do podejmowania wyważonego ryzyka i branie odpowiedzialności za siebie i innych, przy analizowaniu programów kształcenia formalnego warto zwrócić uwagę na ofertę europejskich programów edukacyjnych, w szczególności zaś na wyjazdy edukacyjne, które poprzez realizację swoich celów operacyjnych wspierają działania nastawione na rozwój umiejętności osób uczących się, w szczególności zaś na działania, takie jak: staże i praktyki zawodowe, wolontariat i realizacja części programów studiów oraz praktyk przez polskich studentów za granicą.

Od roku 2014 działania Komisji Europejskiej na rzecz zwiększania mobilności są kontynuowane w ramach programu Erasmus+ (2014-2020), który połączył działalność na rzecz różnych grup docelowych w poszczególnych sektorach edukacji. Projekty mobilności, takie jak wyjazdy kadry, wymiany młodzieżowe, staże, wolontariat europejski, przyczyniają się do zwiększenia wiedzy, umiejętności oraz kompetencji formalnych i pozaformalnych. Stanowią także okazję do zdobywania nowych umiejętności, rozwoju osobistego i zawodowego, a przez to do budowania kapitału ludzkiego i opartego na wiedzy społeczeństwa obywatelskiego w Polsce. Zgodnie z założeniami program Erasmus+ wspiera finansowo projekty mobilności służące podniesieniu poziomu kluczowych kompetencji i umiejętności, szczególnie tych, które są istotne dla odnalezienia się jego uczestników na rynku pracy i które mogą przyczynić się do realizacji priorytetów programu strategicznego UE na rzecz wzrostu gospodarczego, zatrudnienia, sprawiedliwości społecznej i włączenia społecznego (Komisja Europejska 2014).

\section{Szkolnictwo wyższe}

W ofercie programu Erasmus + niezwykle istotną rolę odgrywa wsparcie na rzecz sektora szkolnictwa wyższego. Celem mobilności studentów jest przede wszystkim rozwój kompetencji interpersonalnych, społecznych i językowych oraz rozwój naukowy poprzez uczestnictwo w długoterminowych wyjazdach edukacyjnych. W 2017 r. dokonano analizy raportów indywidualnych uczestników mobilności akademickich, realizowanych w latach 2014-2015 (Dąbrowska-Resiak 2017). Raporty były obowiązkowo wypełniane przez studentów powracających do kraju z projektów mobilności. Wyniki badania pokazały, że studenci odbywający część programów studiów za granicą wysoko ocenili roz- 
wój swoich kompetencji (każda z wymienionych kompetencji została wysoko oceniona przez co najmniej 60 proc. respondentów). Wykres 1 obrazuje ocenę dokonaną przez powracających studentów, przy czym odnosi się ona do odsetka studentów, którzy udzielili odpowiedzi pozytywnej („raczej tak" i „zdecydowanie tak") w odniesieniu do rozwoju wybranych kompetencji.

Wykres 1. Umiejętności rozwinięte podczas wyjazdu na studia i praktyki w latach 2014-2015

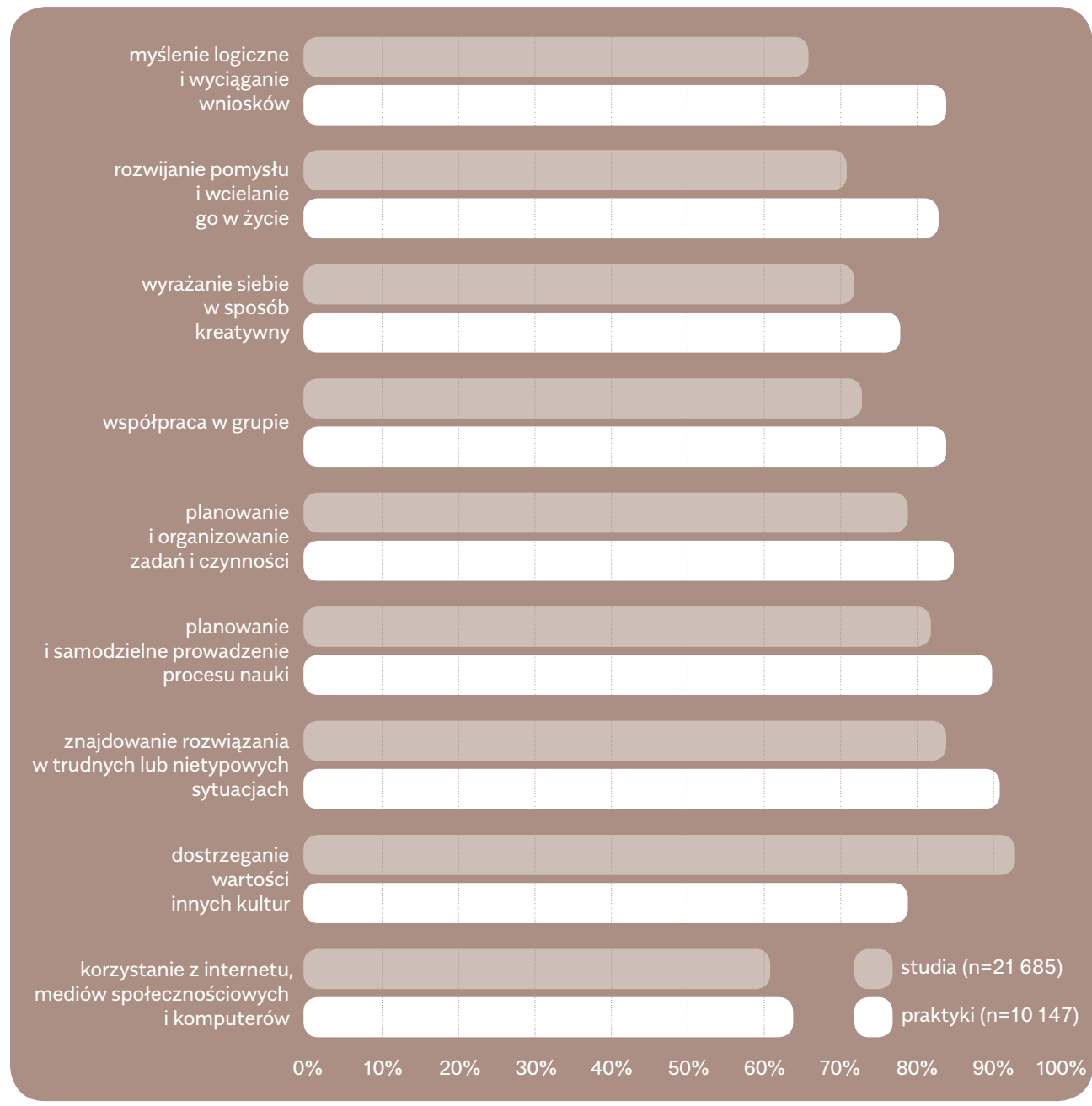

Źródło: J. Dąbrowska-Resiak, Mobilności studentów w programie Erasmus i Erasmus+.

Analiza sprawozdań studentów wyjeżdżających w latach 2007-2015, FRSE, 2017, s. 55. 


\section{Wykres 2. Zmiany zaobserwowane przez studenta po powrocie}

\section{ze studiów i z praktykw latach 2014-2015}

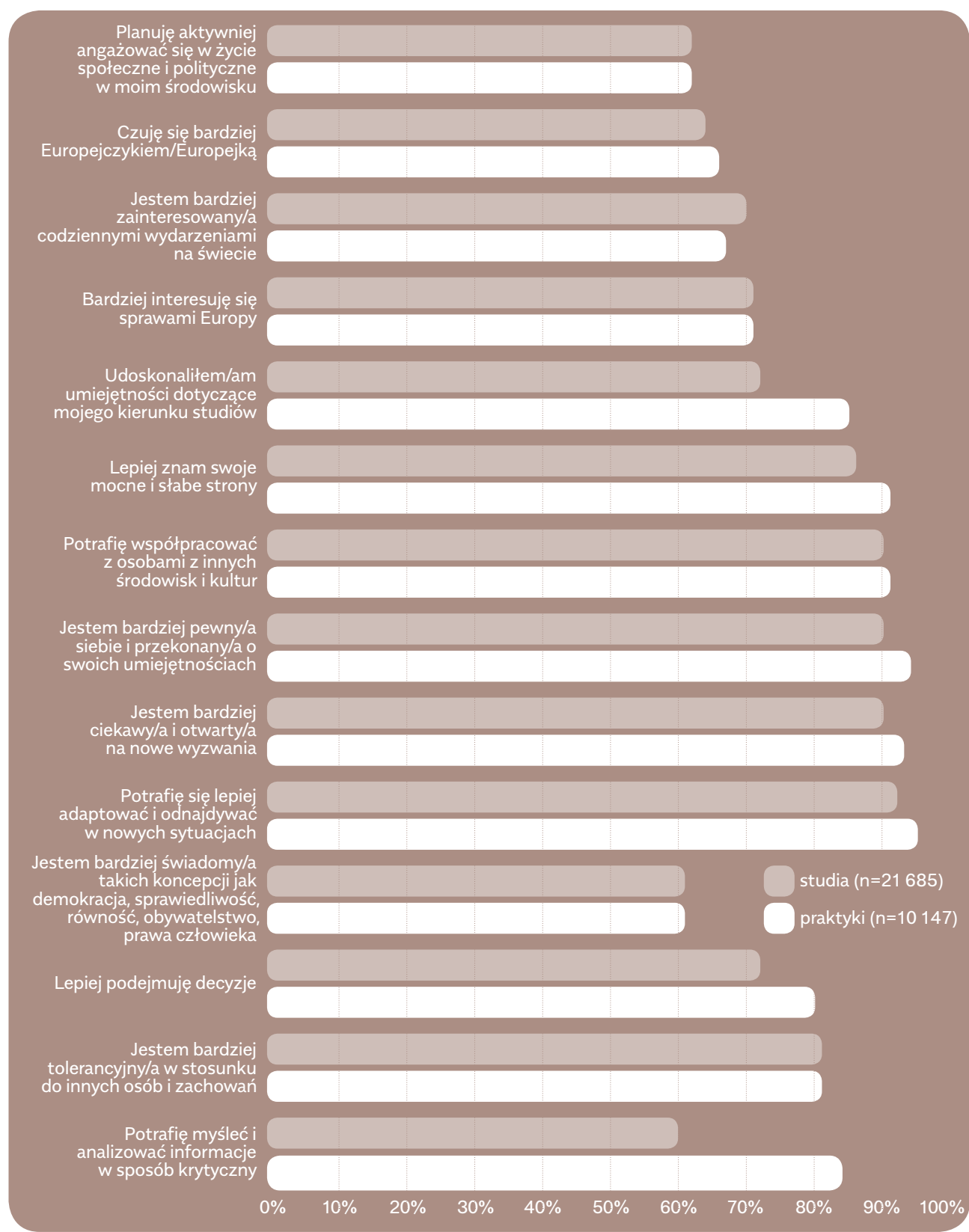

Źródło: J. Dąbrowska-Resiak, Mobilności studentów w programie Erasmus i Erasmus+.

Analiza sprawozdań studentów wyjeżdżających w latach 2007-2015, FRSE, 2017, s. 56. 
Kompetencje, które wpływają na rozwój postaw przedsiębiorczych, zostały w miarę wysoko ocenione przez respondentów: znajdowanie rozwiązania w trudnych lub nietypowych sytuacjach (ponad 84 proc.), samoorganizacja pracy (78,5 proc.), wyrażanie siebie w sposób kreatywny czy rozwijanie pomysłu (oba ponad 70 proc.). Dodatkowo na pytanie o zmiany zaobserwowane przez studentów po powrocie ze studiów (Wykres 2) ponad 72 proc. zauważyło wzrost swoich kompetencji w zakresie decyzyjności. W przypadku grupy studentów odbywających zagraniczne staże i praktyki oceny wskazane przez nich były jeszcze wyższe w każdej z wymienionych kategorii. Prawie 91 proc. wskazało na rozwój kompetencji związanych z umiejętnością odnalezienia się w trudnych lub nietypowych sytuacjach, a 89,5 proc. na rozwinięcie kompetencji planowania i samoorganizacji zadań. Na rozwój kompetencji związanych z kreatywnością wskazało prawie 80 proc. respondentów, a z rozwojem pomysłu i jego wcielaniem w życie ponad 82 proc. Nieco wyżej grupa ta oceniła także swoją decyzyjność - ponad 80 proc. zaobserwowało pozytywną zmianę w tym zakresie. Na uwagę zasługuje również umiejętność adaptacji i odnajdowania się w nowych sytuacjach - ponad 90 proc. studentów po powrocie ze studiów i powracających z programów praktyk zaobserwowało rozwój tej umiejętności.

Ponad 6 proc. studentów wyjeżdżających na studia i 7 proc. odbywających zagraniczne praktyki lub staże odpowiedziało twierdząco na pytanie o udział w działaniach, które prowadziły do powstania innowacyjnego produktu lub odkrycia. Respondenci interpretowali owe działania bardzo szeroko - jako uczestnictwo zarówno w projektach badawczych, jak i w zajęciach dydaktycznych, w trakcie których wykorzystywano nowe metody nauczania, czy jako zdobycie inspiracji do rozpoczęcia własnej działalności gospodarczej lub rozwoju już istniejących. Mimo iż trudno jest ocenić, jak uczestnictwo w tych działaniach przełożyło się na późniejszy rozwój innowacyjnych usług lub produktów, z wypowiedzi respondentów wynika, że mieli oni możliwość bądź aktywnego zaangażowania w działania, które wpływały na rozwój kompetencji związanych z rozwojem pomysłu, bądź ich obserwacji.

\section{Edukacja zawodowa}

W 2017 r. przeprowadzone zostało badanie losów absolwentów staży i praktyk zawodowych realizowanych $w$ ramach europejskich pro- 
gramów edukacyjnych: Leonardo da Vinci, Erasmus+ oraz projektów dofinansowanych ze środków Europejskiego Funduszu Społecznego. Wyniki badania pokazały, że dzięki doświadczeniu zagranicznej mobilności zawodowej uczestnicy mogli nie tylko zobaczyć, jak wygląda praca i praktyczna nauka zawodu w innym kraju europejskim, lecz także (często po raz pierwszy) sprawdzić się na danym stanowisku pracy. Niemal wszyscy badani uczestnicy wyjazdów zauważali, że zagraniczna mobilność wpływa na rozwój różnych kompetencji, nie tylko tych stricte zawodowych, lecz także językowych, społecznych oraz umiejętności miękkich (Wykres 3). Respondenci bardzo docenili wpływ stażu na rozwój ich umiejętności interpersonalnych. Ponad 69 proc. absolwentów staży przyznało, że doświadczenie pracy za granicą ułatwia im nawiązywanie znajomości. Dzięki wyjazdom potrafią także lepiej realizować zadania w zespołach (ponad 77 proc.) oraz pracować w międzynarodowym środowisku (ponad 74 proc.).

Wykres 3. Korzyści wynikające z realizacji zagranicznych staży

i praktyk w opinii uczestników wyjazdów

\section{Udział w stażu za granicą pozwolił mi...}

... zapoznać się z innymi niż w Polsce

zasadami pracy, funkcjonowania firm i środowiska branżowego ... zapoznać się z innymi niż w Polsce środowiskiem zawodowym, organizacją i kulturą pracy ... zwiększyć moje szanse na znalezienie pracy za granicą ... zwiększyć moje szanse na znalezienie pracy w Polsce ... nauczyć się tych elementów zawodu, których nie miałbym/miałabym okazji poznać w mojej szkole

"... zapoznać się z innymi niż w Polsce sposobami nauki zawodu"

"... zdobyć praktyczne doświadczenie zawodowe"

(n = 2592)

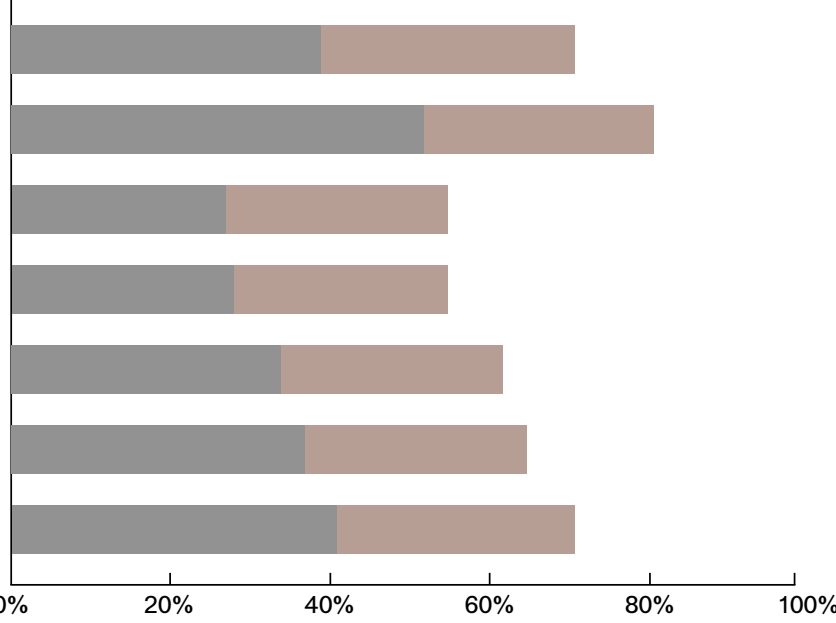

W bardzo wysokim stopniu

Raczej w wysokim stopniu

Źródło: M. Pachocki, Mobilność kluczem do kariery? Raport z badania losów uczestników zagranicznych staży i praktyk zawodowych, Fundacja Rozwoju Systemu Edukacji, Warszawa 2018. 
Większość badanych podkreślała, że udział w stażu w znacznym stopniu przyczynił się do rozwijania u nich kompetencji miękkich. Uczestnicy staży często zaznaczali, że udział w mobilności nauczył ich lepiej pokonywać stres oraz radzić sobie w trudnych i nietypowych sytuacjach. Deklarowane zmiany dotyczyły bardzo różnych aspektów, związanych m.in. z podejmowaniem inicjatywy, umiejętnością pracy w zespole czy większą otwartością. Uczestnicy badania kwestionariuszowego podkreślali, że projekty mobilności edukacyjnej miały duży wpływ na ich samodzielność. Dotyczyło to zwłaszcza wyjazdów zakładających nie tylko pracę w firmach, lecz także konieczność samodzielnego organizowania takich aspektów pobytu za granicą jak dojazd do miejsca pracy czy wyżywienie, co wymagało samokontroli i rozsądnego dysponowania środkami przyznanymi w ramach kieszonkowego. Uczestnicy badania często podkreślali również, że już sam fakt poradzenia sobie w nowych warunkach zdecydowanie wzmocnił ich pewność siebie i stawał się impulsem do podejmowania nowych inicjatyw po powrocie do kraju. Ponad połowa uczestników badania ankietowego przyznała, że udział w projektach mobilności edukacyjnej pomógł im później znajdować odpowiednie rozwiązania w trudnych i nietypowych sytuacjach (ponad 59 proc. badanych) oraz radzić sobie ze stresem (ponad 56 proc.) - wykres 4 . Zdecydowana większość respondentów stwierdziła natomiast, że dzięki udziałowi w stażu nabyła umiejętność planowania i samodzielnej nauki (ponad 51 proc. badanych potwierdziło, że wpływ ten był bardzo zauważalny) oraz lepszego zarządzania czasem (ponad połowa respondentów oceniła, że wpływ stażu na tę umiejętność był zauważalny). Uczestnicy badania zwrócili także uwagę na to, że staż znacząco wpłynął na sposób organizowania ich pracy - ponad 57 proc. ankietowanych dzięki mobilności edukacyjnej nabyło umiejętność planowania i organizowania podejmowanych zadań oraz czynności. 
Wykres4. Wpływ stażu na kompetencje miękkie uczestników wyjazdów

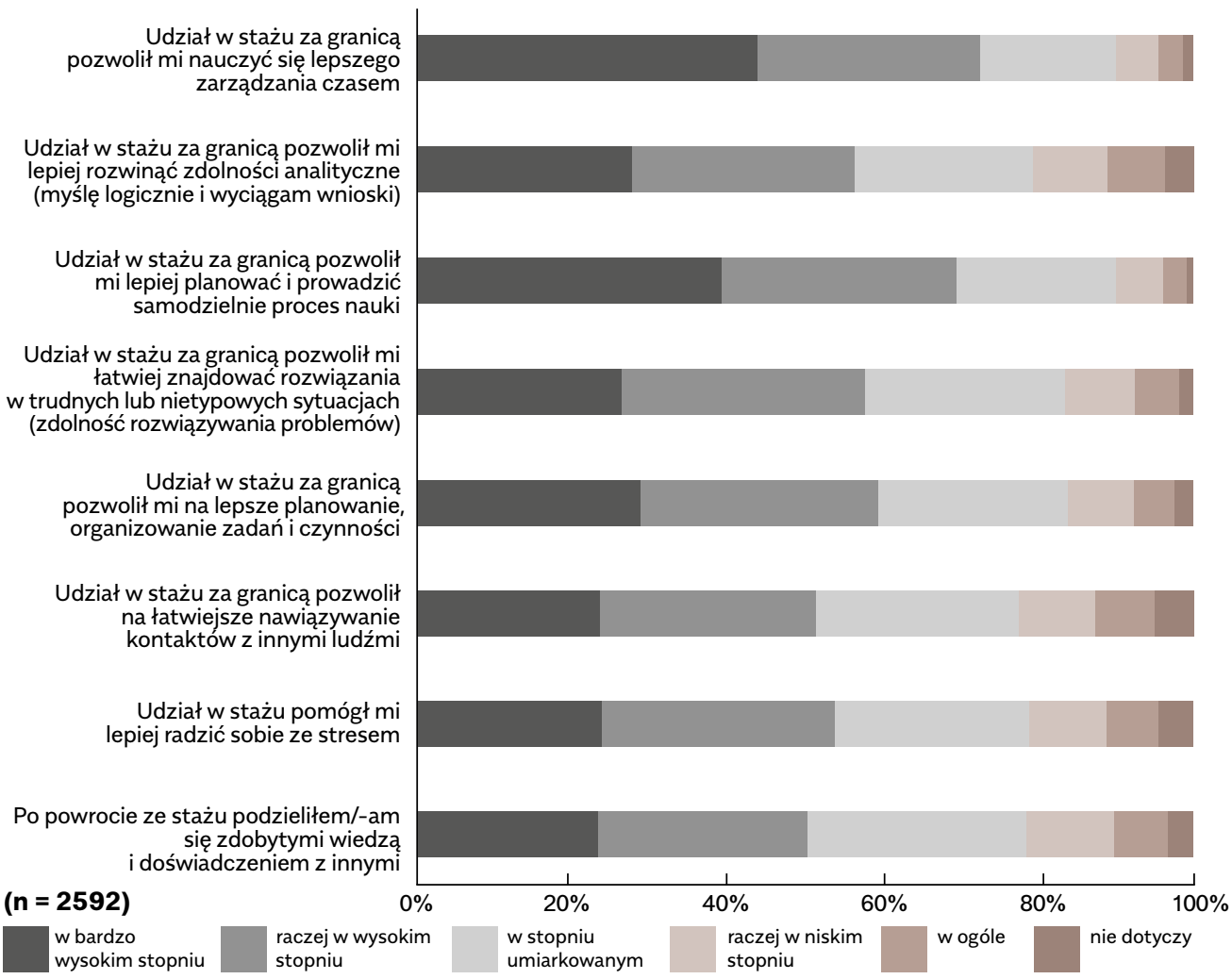

Źródło: M. Pachocki, Mobilność kluczem do kariery? Raport z badania losów uczestników

zagranicznych staży i praktyk zawodowych, Fundacja Rozwoju Systemu Edukacji, Warszawa 2018.

Większość uczestników badania była zgodna, że takie wyjazdy mogą mieć również istotny wpływ zarówno na wybór dalszej ścieżki kształcenia, jak i dalsze życie zawodowe. Wyniki badania pokazały, że wśród absolwentów aktywnych na rynku pracy około 5 proc. stanowiły osoby samozatrudnione lub prowadzące własną działalność gospodarczą. Należy jednak pamiętać, że - szczególnie w przypadku młodych absolwentów szkół zawodowych - o możliwości pracy na własny rachunek często decyduje branża kształcenia, a nie jedynie kompetencje zdobyte w trakcie nauki. Warto natomiast podkreślić, że ponad 86 proc. byłych uczestników staży i praktyk zagranicznych, którzy są samozatrudnieni 
lub prowadzą inne formy działalności gospodarczej, zauważyło związek między doświadczeniem praktycznej nauki za granicą a rozwojem postaw związanych z przedsiębiorczością (Wykres 5). Jednocześnie ponad 73 proc. badanych potwierdziło zgodność tematyki stażu z obszarem obecnej działalności zawodowej.

Wykres 5. Wpływ stażu na kompetencje miękkie uczestników wyjazdów ( $\mathrm{n}=58)$

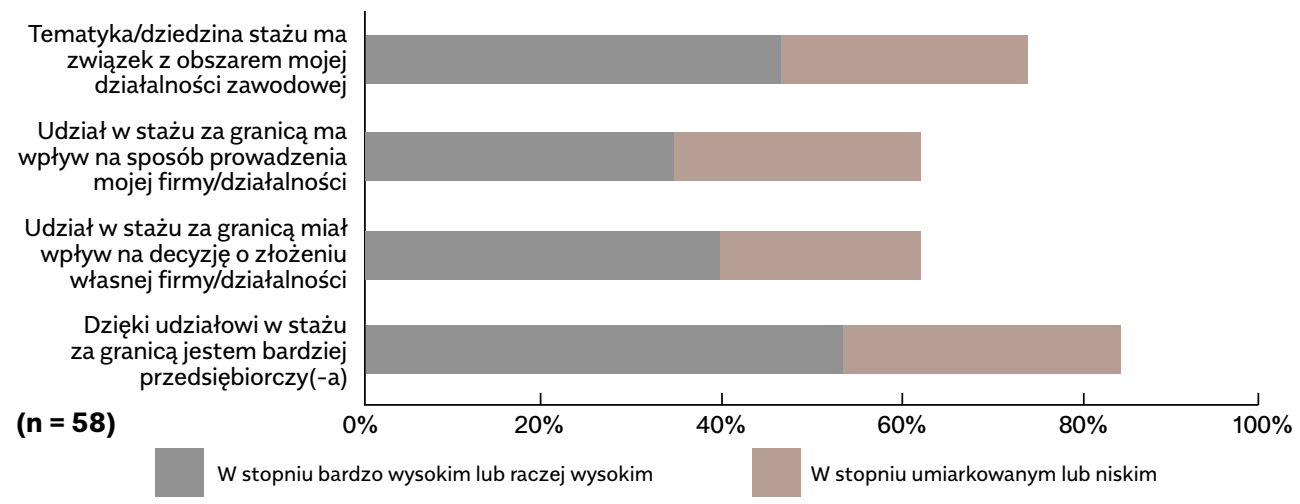

Źródło: M. Pachocki, Mobilność kluczem do kariery? Raport z badania losów uczestników zagranicznych staży i praktyk zawodowych, Fundacja Rozwoju Systemu Edukacji, Warszawa 2018.

\section{Edukacja pozaformalna}

Doświadczenia realizacji europejskich programów edukacyjnych pokazują, że na wzrost kompetencji związanych z przedsiębiorczością mają wpływ także projekty realizowane poza szkołą. O ile uczestnictwo w edukacji formalnej jest do pewnego wieku obowiązkowe i wynika zazwyczaj z motywacji zewnętrznej, o tyle edukacja pozaformalna oparta jest na dobrowolnym uczestnictwie i zależy najczęściej od wewnętrznej motywacji uczącego się. Cel nauki w edukacji formalnej jest określony odgórnie i zależy od programu nauczania, natomiast w edukacji pozaformalnej jest on określony przez osobę uczącą się. Ponadto, relacje uczących się z prowadzącymi zajęcia oparte są na odmiennych zasadach: o ile w edukacji formalnej prowadzący (nauczyciel, wykładowca) realizuje program nauczania i opiera się na zasadzie uczeń-mistrz, o tyle w edukacji pozaformalnej prowadzący zajęcia (facylitator) jest moderatorem procesu i podąża za procesem uczenia się uczestników, a re- 
lacje z nimi oparte są na zasadach partnerskich i zakładają zmienność ról: uczestnicy mogą przekazywać wiedzę facylitatorowi oraz innym uczestnikom procesu uczenia się.

Potwierdzają to badania prowadzone przez kilkanaście narodowych agencji programu Erasmus+ we współpracy z Instytutem Badań nad Edukacją Uniwersytetu w Innsbrucku. Wyniki Badania efektów uczenia się w programie Erasmus+ Młodzież (Fennes i in. 2017) pokazują, że uczestnictwo w projektach międzynarodowych opartych na zasadach edukacji pozaformalnej może prowadzić do rozwoju wielu kompetencji przydatnych w życiu zawodowym. Ponad 23 proc. ankietowanych uczestników projektów programu Erasmus+ Młodzież stwierdziło, że dzięki udziałowi w projekcie stało się bardziej przedsiębiorczymi (Wykres 6). 33 proc. zaś zadeklarowało, że polepszyły się ich umiejętności zarządzania projektem. Najczęściej deklaracje te dotyczyły uczestników projektów mobilności osób pracujących z młodzieżą i Wolontariatu Europejskiego, czyli działań, w których udział biorą starsi uczestnicy, niż np. wymian młodzieżowych. Warto zaznaczyć także, że ponad 95 proc. ankietowanych zadeklarowało, iż dzięki uczestnictwu w projekcie stało się bardziej pewnymi siebie.

Wykres 6. Które z umiejętności rozwinąłeś (rozwinęłaś) poprzez

uczestnictwo w projekcie? Odsetek odpowiedzi twierdzących

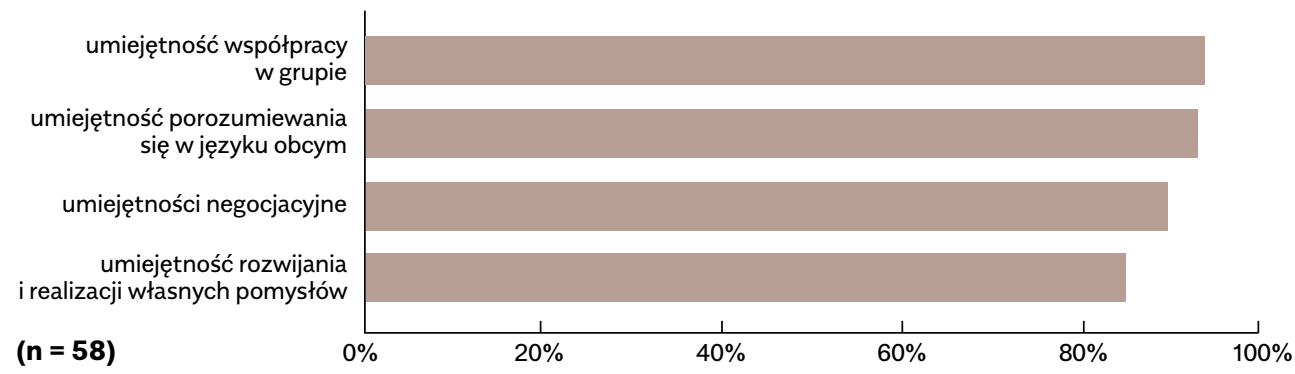

Źródło: H. Fennes, D. Bammer, A. Karsten, Exploring Erasmust: Youth in action. Effects and outcomes of the Erasmus+: Youth in action programme from the perspective of project participants and project leaders, Institute of Educational Science, Innsbruck 2017. 
Jeśli chodzi o kompetencje związane z przedsiębiorczością rozwijane podczas projektów programu Erasmus+ Młodzież, to uczestnicy mobilności najczęściej wskazywali na: umiejętność porozumiewania się w języku obcym (93,3 proc. pozytywnych odpowiedzi), umiejętność współpracy w grupie (94,1 proc.), rozwijanie i realizację własnych pomysłów (85,2 proc.), umiejętności negocjacyjne (89,9 proc.). Tak wysoki odsetek odpowiedzi twierdzących może być spowodowany specyfiką projektów programu Erasmus+ Młodzież. Zgodnie z jego zasadami w wielu przypadkach to właśnie młodzi ludzie byli autorami i realizatorami tych działań. Ich pomysły często wynikały z własnych zainteresowań lub potrzeb lokalnej społeczności. Młodzi ludzie zaś byli odpowiedzialni za realizację projektu, począwszy od opracowania koncepcji, przygotowania i złożenia wniosku o dofinansowanie, jego realizacji, na rozliczeniu finansowym skończywszy.

$Z$ kolei wyniki badania Kompetencje zdobywane w ramach Wolontariatu Europejskiego w kontekście wymogów rynku pracy pokazują, że ponad 94 proc. ankietowanych byłych wolontariuszy uważa wiedzę i umiejętności zdobyte podczas zagranicznego wolontariatu długoterminowego za przydatne $w$ życiu zawodowym, a jedynie niespełna 6 proc. uznaje je za nieprzydatne. Co więcej, cenią je oni bardziej niż wiedzę zdobytą w szkole czy na uczelni, choć często podkreślają komplementarny charakter tych dwóch typów doświadczeń edukacyjnych, na przykład w odniesieniu do znajomości języka obcego, którego podstaw nauczyli się w szkole, a swoje kompetencje w tym zakresie rozwinęli podczas projektu Wolontariatu Europejskiego.

Należy także zauważyć, że aż 79 proc. ankietowanych byłych wolontariuszy posiadało doświadczenie zawodowe przed realizacją projektu wolontariatu (65,5 proc. ankietowanych z grupy $18-24$ lata i 89,5 proc. z grupy $25+$ ), a ponad 81 proc. łączyło zdobywanie doświadczenia zawodowego $z$ nauką. Warto odnotować także różnice w odpowiedziach na pytanie o przydatność kompetencji i umiejętności zdobywanych w edukacji pozaformalnej, które rysują się przy podziale na grupy wiekowe. Młodsi wolontariusze zdecydowanie częściej twierdzili, że umiejętności zdobyte dzięki uczestnictwu w projekcie Wolontariatu Europejskiego są bardzo przydatne na rynku pracy, starsi zaś wykazywali więcej rezerwy i zdecydowanie częściej odpowiadali, że umiejętności te są przydatne do pewnego stopnia. Podobnie jak w przypadku pytania o edukację formalną odsetek osób twierdzących, że kompetencje 
i umiejętności zdobywane w edukacji pozaformalnej nie są wcale przydatne, jest stosunkowo niewielki.

\section{Podsumowanie}

Przytoczone dane pokazują, że uczestnictwo w długoterminowych zagranicznych mobilnościach edukacyjnych może wpływać zarówno na rozwój wiedzy i umiejętności uczestniczących w nich młodych ludzi, jak i na kształtowanie w nich postaw przedsiębiorczych. Młodzi ludzie, uczestnicząc w tego typu projektach, stają się bardziej samodzielni, uczą się odpowiedzialności, planowania i współpracy w grupie. Mogą także w innym niż szkolne otoczeniu sprawdzić w praktyce swoją wiedzę i swoje umiejętności. Ponadto świadomość, że poradzili sobie za granicą podczas długoterminowej pracy w środowisku zbliżonym do zawodowego, sprzyja budowaniu ich pewności siebie - postawie jakże ważnej wśród przyszłych przedsiębiorców. 


\section{Bibliografia}

$\rightarrow$ Dardziński, P., Dulak, M., Jelonek, M., Kędzierski, M., Krupnik, S., Przybylski, W., Rzegocki, A., Staniłko, J.F. (2015), Przedsiębiorczość, głupcze! Jak wejść na drogę do bogactwa?, Kraków: Fundacja Lepsza Polska.

$\rightarrow$ Dąbrowska-Resiak, J. (2017), Mobilności studentów w programie Erasmus i Erasmus+. Analiza sprawozdań studentów wyjeżdżających w latach 2007-2015, www.frse.org.pl/wp-content/uploads/2017/12/Mobilności-studentów-w-progr-Erasmus-i-Erasmus_FINAL.pdf, Warszawa: FRSE.

$\rightarrow$ Erasmus+ Programme Guide. Valid as of 1 January 2014, Version 3: 09/04/2014 (2014), Brussels: European Commission.

$\rightarrow$ Górniak, J., Kocór, M., Czarnik, S., Magierowski, M., Kasparek, K., Jelonek, M., Turek, K., Worek, B. (2015), Polski rynek pracy - wyzwania i kierunki działań na podstawie badań Bilans Kapitału Ludzkiego 2010-2015, Warszawa: PARP.

$\rightarrow$ Helmut, F., Bammer, D., Karsten, A. (2017), Exploring Erasmust: Youth in action. Effects and outcomes of the Erasmus+: Youth in action programme from the perspective of project participants and project leaders", Innsbruck: Institute of Educational Science.

$\rightarrow$ Fells, M., Płatos, B., Rybińska, A. (2018), Kompetencje kluczowe uczniów w międzynarodowych raportach i badaniach [w:] S. Kwiatkowski (red.), Kompetencje przyszłości, Warszawa: FRSE.

$\rightarrow$ Górniak, J. (red.) (2015), Polski rynek pracy - wyzwania i kierunki działań, Warszawa- Kraków: PARP.

$\rightarrow$ Jeżowski, M. (2018), Kompetencje zdobywane w ramach Wolontariatu Europejskiego w kontekście wymogów rynku pracy, Warszawa: FRSE.

$\rightarrow$ Kocór, M., Strzebońska, A., Dawid-Sawicka, M. (2015), Rynek pracy widziany oczami pracodawców. Na podstawie badań pracodawców i ofert pracy zrealizowanych w 2014 roku w ramach V edycji projektu Bilans Kapitału Ludzkiego, Warszawa: PARP. 
$\rightarrow$ Kompetencje kluczowe. Realizacja koncepcji na poziomie szkolnictwa obowiq̨zkowego (2005), Warszawa: FRSE.

$\rightarrow$ Komunikat Komisji do Rady, Parlamentu Europejskiego, Europejskiego Komitetu Ekonomiczno-Społecznego i Komitetu Regionów (2009), Bruksela: Komisja Wspólnot Europejskich.

$\rightarrow$ Pachocki, M. (2018), Mobilność kluczem do kariery? Raport z badania losów uczestników zagranicznych staży i praktyk zawodowych, Warszawa: FRSE.

$\rightarrow$ Rachwał, T. (2005), Kształtowanie postaw uczniów na lekcjach podstaw przedsiębiorczości [w:] „Przedsiębiorczość-Edukacja”, nr 1, s. 137-144.

$\rightarrow$ Rozporzq̨dzenie Parlamentu Europejskiego i Rady (UE) nr 1288/2013 z dnia 11 grudnia 2013 r. ustanawiajqce Erasmus+: unijny program na rzecz kształcenia, szkolenia, młodzieży i sportu oraz uchylajqce decyzje nr 1719/2006/ WE, 1720/2006/WE i 1298/2008/WE (2013), Parlament Europejski i Rada Unii Europejskiej, Bruksela.

$\rightarrow$ Szczucka, A., Jelonek, M. (2011), Kogo kształcq polskie szkoły, Warszawa: PARP.

$\rightarrow$ Szwałek, K. (red.), Raport 2007-2013. Programy "Uczenie się przez całe życie" oraz "Młodzież w działaniu" w Polsce (2014), Warszawa: FRSE.

$\rightarrow$ The Lisbon Strategy in short, Komisja Europejska, portal.cor.europa.eu/europe2020/Profiles/Pages/TheLisbonStrategyinshort.aspx. 


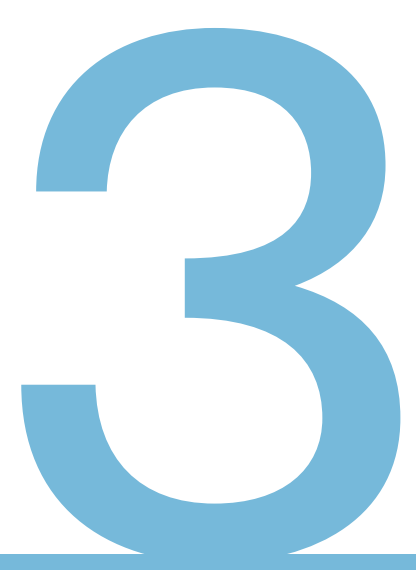


Doświadczenia międzynarodowe

w zakresie ksztaltowania

kompetencji

przedsiębiorczych 


\section{Kompetencja kluczowa czy przedmiot szkolny? Nauczanie przedsiębiorczości w szkołach w Europie}

Magdalena Górowska-Fells, Beata Płatos

Tekst jest poświęcony tematyce nauczania przedsiębiorczości jako jednej z kompetencji kluczowych w szkołach w Europie. Informuje o sposobach włączania treści o tematyce dotyczącej przedsiębiorczości do programów szkolnych na poziomie szkoły podstawowej i średniej - zarówno pierwszego, jak i drugiego stopnia. Omawia również stosowane narzędzia dydaktyczne oraz metody nauczania, w tym uczenie się poprzez zaangażowanie w działania firm/przedsiębiorstw szkolnych. Analizą objęto nauczanie realizowane w ramach zajęć obowiązkowych, zajęć dodatkowych i projektów szkolnych oraz pozaszkolnych.

\section{Słowa kluczowe:}

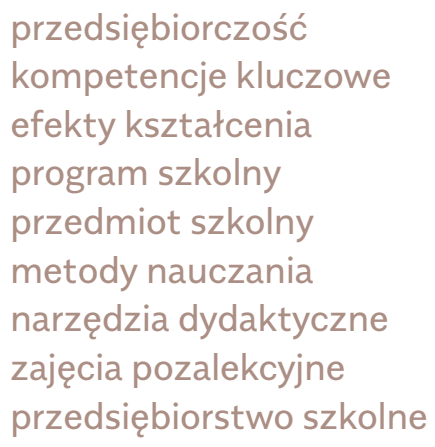




\section{Key competence or school subject? Entrepreneurship education in schools in Hurope}

Magdalena Górowska-Fells, Beata Płatos

The article is devoted to the topic of teaching entrepreneurship at school in Europe as one of the key competences. It presents ways of including entrepreneurship in the school programmes at the level of primary and both lower and upper secondary education. It informs about didactic tools and teaching methods used at school including learning through involvement in school enterprises. Entrepreneurship is discussed as implemented during both compulsory and extracurricular classes, as well as projects implemented at school and outside.

\section{Keywords:}

entrepreneurship

key competences

learning outcomes

school programme

school subject

teaching methods

didactic tools

extracurricular classes

school enterprise 


\section{Wstęp}

Przedsiębiorczość, jako jedna z kompetencji kluczowych, jest od kilku lat systematycznie włączana do programów szkolnych w większości krajów Europy. Proces ten jest szczegółowo analizowany przez sieć Eurydice, która opublikowała dwa raporty dotyczące nauczania przedsiębiorczości w szkołach w Europie - w latach 2012 i 2016 - oraz planuje opracowanie kolejnego ( $w$ roku 2019). W raporcie Eurydice $z$ roku 2016 można prześledzić, jak poszczególne kraje (w sumie 33) realizują nauczanie przedsiębiorczości. Analizę przeprowadzono na podstawie zapisów w legislacji krajowej, a nie na podstawie badań prowadzonych w szkołach, ale możemy założyć, że szkoły korzystają z zaleceń dotyczących zarówno treści (odpowiednik polskiej podstawy programowej), jak i metod dydaktycznych, gdyż przeważnie są później z tego rozliczane. Celem niniejszego tekstu jest przedstawienie, na podstawie analizy dostępnych raportów, jak przedsiębiorczość wpisuje się w programy szkolne w Europie i jak kształtowane są związane z nią kompetencje.

\section{Włączanie przedsiębiorczości do programów szkolnych}

Większość krajowych definicji przedsiębiorczości stosowanych w krajowych dokumentach strategicznych dotyczących edukacji i w programach szkolnych jest spójna z europejską definicją kompetencji kluczowych. Większość z tych definicji ma szeroki charakter odnoszący się nie tylko do rynku pracy i działalności gospodarczej, lecz także do ogólnego kontekstu funkcjonowania jednostki w życiu społecznym (zob. Borowiec-Gabryś, Kilar, Rachwał 2018; Rachwał i in. 2018; Wach 2013).

Przedsiębiorczość jest włączana w Europie do szkolnych programów nauczania na różne sposoby. Nauczanie jej może się odbywać w ramach odrębnego przedmiotu lub może być zintegrowane $z$ innymi przedmiotami. Może być ono uwzględnione w programie szkolnym jako obowiązkowe lub fakultatywne. Wiele ciekawych działań jest realizowanych w ramach zajęć dodatkowych, pozalekcyjnych czy inicjatyw i projektów prowadzonych przez instytucje współpracujące ze szkołami (Eurydice 2016).

Treści dotyczące przedsiębiorczości w programach nauczania są najczęściej realizowane w ramach:

$\rightarrow$ międzyprzedmiotowych celów kształcenia - cele dotyczące przedsiębiorczości są wpisane w ogólne cele kształcenia i/lub wplecione w treści szczegółowe kilku/wielu przedmiotów, 
$\rightarrow$ odrębnego obowiązkowego przedmiotu szkolnego (lub przedmiotów) poświęconego wyłącznie nauczaniu przedsiębiorczości,

$\rightarrow$ odrębnego przedmiotu fakultatywnego (lub przedmiotów) poświęconego wyłącznie nauczaniu przedsiębiorczości.

Podejścia nie wykluczają się i mogą w poszczególnych krajach występować równolegle (Eurydice 2016).

\section{Szkolnictwo podstawowe i średnie pierwszego stopnia}

Z raportu Komisji Europejskiej wynika, że najczęściej edukację w zakresie przedsiębiorczości zaczyna się od pojedynczych treści lub ogólnych celów kształcenia w młodszym wieku (np. w szkole podstawowej), a następnie treści dotyczące przedsiębiorczości są rozbudowywane na poziomie szkolnictwa średniego jako obowiązkowa, integralna część programu nauczania (McCoshan, za: Eurydice 2016).

Z raportu Eurydice z 2016 r. wynika, że prawie połowa krajów stosuje w szkolnictwie podstawowym podejście międzyprzedmiotowe, nie wiążąc celów ani treści nauczania przedsiębiorczości z konkretnymi przedmiotami. W Estonii, gdzie realizowana jest strategia na rzecz popularyzacji nauczania przedsiębiorczości w szkolnictwie podstawowym, kompetencja "bycia przedsiębiorczym" (umiejętność działania w sposób przedsiębiorczy) powinna być rozwijana w trakcie całego procesu kształcenia. Oprócz celów interdyscyplinarnych funkcjonuje tam również ścieżka międzyprzedmiotowa - inicjatywa obywatelska i przedsiębiorczość. Kształcenie kompetencji przedsiębiorczych jest realizowane w ramach wszystkich obszarów nauczania na poziomie szkoły podstawowej także w Hiszpanii i Słowenii. Cztery kraje (Czechy, Łotwa, Malta i Rumunia) stosują wszystkie trzy podejścia - łączą cele międzyprzedmiotowe z obowiązkową nauką przedsiębiorczości oraz oferują przedmioty do wyboru.

W kilku systemach w szkolnictwie podstawowym treści dotyczące przedsiębiorczości znalazły się w programach nauczania przedmiotów obowiązkowych, np. w Austrii i na Słowacji. Natomiast przedmioty do wyboru są w szkolnictwie podstawowym rzadko spotykane i w związku z tym przedmiot fakultatywny uwzględniający przedsiębiorczość występuje bardzo rzadko.

Z kolei w szkolnictwie średnim pierwszego stopnia, częściej niż w podstawowym, łączy się różne podejścia - osiem krajów łączy wszystkie trzy opcje. Najczęściej (w 17 krajach) obserwowane jest 
obowiązkowe nauczanie przedsiębiorczości jako oddzielnego przedmiotu lub w ramach innego przedmiotu/przedmiotów, znacznie częściej niż w szkolnictwie podstawowym. Także występowanie treści nauczania dotyczących przedsiębiorczości jako przedmiotu do wyboru jest bardziej powszechne niż w szkolnictwie podstawowym. Tylko osiem krajów nie włączyło w żaden sposób treści związanych z przedsiębiorczością do programów nauczania (Eurydice 2016).

W szkolnictwie podstawowym i średnim pierwszego stopnia przedsiębiorczość jest odrębnym obowiązkowym przedmiotem tylko w czterech krajach. Pozostałe włączają treści dotyczące przedsiębiorczości do takich przedmiotów jak nauki społeczne i ekonomiczne, poradnictwo zawodowe, matematyka, przedmioty ścisłe, technika, TIK, a nawet sztuka, muzyka, języki obce, rozwój osobisty oraz etyka. Nauczanie przedsiębiorczości jest najczęściej zintegrowane z przedmiotami w dziedzinie nauk społecznych oraz ekonomii. W Polsce w dotychczasowym systemie sześcioletniej szkoły podstawowej i trzyletniego gimnazjum była ona włączona głównie w przedmiot wiedza o społeczeństwie na poziomie gimnazjalnym (Rachwał, Kurek, Boguś 2016).

\section{Szkolnictwo średnie drugiego stopnia - ogólnokształcące i zawodowe}

Nauczanie przedsiębiorczości jest bardziej rozpowszechnione w szkołach średnich drugiego stopnia niż w szkolnictwie podstawowym i średnim pierwszego stopnia. Na tym poziomie znacznie częściej szkoły mają za zadanie realizowanie treści dotyczących przedsiębiorczości jako celu międzyprzedmiotowego (20 krajów), również częściej spotykane jest łączenie wszystkich trzech podejść (cel międzyprzedmiotowy, przedmiot obowiązkowy oraz przedmioty do wyboru). Nauka przedsiębiorczości jest obowiązkowa w 18 krajach, a jedynie w pięciu w ogóle jej się nie uwzględnia w programach. Realizacja najczęściej polega na wyodrębnieniu osobnego przedmiotu (dotyczy to połowy krajów), częściej w formie fakultatywnej niż obowiązkowej. Taki model prowadzony jest w Polsce, gdzie we wszystkich szkołach średnich (ogólnokształcących i zawodowych) realizowany jest obowiązkowy przedmiot podstawy przedsiębiorczości (Rachwał i in. 2018).

Również w szkolnictwie zawodowym przedsiębiorczość to najczęściej oddzielny przedmiot, równie często obowiązkowy, co do wyboru (odpowiednio dziewięć i 10 krajów). Tam, gdzie nie ustanowiono 
odrębnego przedmiotu, przedsiębiorczość jest najczęściej nauczana w ramach nauk społeczno-ekonomicznych. Ciekawy jest przypadek Holandii, gdzie szkoły mają dużą autonomię w dziedzinie doboru treści nauczania, w tym przedsiębiorczości. Przeważnie realizują projekty i wprowadzają treści dotyczące przedsiębiorczości do swoich programów nauczania (na wszystkich poziomach szkolnictwa), mimo że nie mają takiego obowiązku.

Podsumowując: nauczanie przedsiębiorczości jest stopniowo wprowadzane w szkołach podstawowych i średnich pierwszego stopnia, często jako ścieżka międzyprzedmiotowa, a pełna realizacja celów nauczania następuje w szkołach średnich drugiego stopnia.

\section{Efekty kształcenia w dziedzinie przedsiębiorczości}

Analiza treści nauczanych w ramach przedmiotu czy przedmiotów uwzględniających problematykę przedsiębiorczości pozwala na dostrzeżenie pewnego charakterystycznego zjawiska. W podstawach programowych nie mówi się obecnie o treściach nauczania ani wiedzy, którą należy przekazać. Podstawy programowe (w tym polska) są sformułowane w języku efektów kształcenia. Jeśli chcemy się dowiedzieć, jakich treści naucza się w szkołach, to musimy zapoznać się z opisem wyników tego kształcenia, czyli tego, co uczeń będzie potrafił po skończeniu edukacji.

Na potrzeby analiz prowadzonych przez Eurydice wyróżniono trzy kategorie efektów kształcenia występujące w europejskich programach nauczania przedsiębiorczości. Są to:

$\rightarrow$ postawy (pewność siebie i inicjatywność),

$\rightarrow$ umiejętności (kreatywne rozwiązywanie problemów, planowanie, stosowanie wiedzy z zakresu finansów, organizowanie zasobów, zarządzanie ryzykiem oraz praca zespołowa),

$\rightarrow$ wiedza (ocena warunków do działalności gospodarczej, rola przedsiębiorców w społeczeństwie i ścieżki kariery w biznesie).

Wprowadzenie powyższych kategorii ułatwiło przeprowadzenie porównań międzykrajowych. W szkolnictwie podstawowym i średnim pierwszego stopnia odnotowano częste występowanie efektów kształcenia odnoszących się do postaw przedsiębiorczych oraz umiejętności takich jak: kreatywne rozwiązywanie problemów, planowanie, stosowanie wiedzy z zakresu finansów i praca zespołowa oraz w kategorii 
wiedza - roli przedsiębiorców w społeczeństwie. Pozostałe kategorie występowały rzadko, zdecydowanie najrzadziej występującym efektem kształcenia w kategorii umiejętności było organizowanie zasobów i zarządzanie ryzykiem, w kategorii wiedzy - ocena warunków do działalności gospodarczej oraz ścieżki kariery w przedsiębiorczości. Badania nad polską podstawą programową wskazywały na dominację kategorii efektów kształcenia związanych bardziej z wiedzą ekonomiczną niż kształtowaniem umiejętności i postaw przedsiębiorczych. Dlatego w nowej podstawie programowej położono większy nacisk na kształtowanie postaw, stosowanie wiedzy w praktyce i rozwój umiejętności związanych z przedsiębiorczością (Rachwał, Kurek, Boguś 2016; Rachwał i in. 2018).

Z kolei w szkolnictwie średnim drugiego stopnia i w szkołach zawodowych występowanie poszczególnych kategorii efektów kształcenia jest zbliżone do tego na niższych poziomach - podobieństwo to dotyczy aż 20 krajów. Różnice są niewielkie i związane np. z występowaniem pracy zespołowej, która nieco częściej jest wymieniana dla poziomów niższych. Największe różnice dotyczą efektów kształcenia związanych z umiejętnościami, które rzadko występowały na niższych szczeblach kształcenia, czyli z organizowaniem zasobów, zarządzaniem ryzykiem czy w kategorii wiedza - oceną warunków do działalności gospodarczej, czyli czy dany pomysł biznesowy uda się z sukcesem zrealizować w konkretnych warunkach. Występują one znacznie częściej w programach dla szkół średnich drugiego stopnia oraz zawodowych niż na niższych poziomach kształcenia. Wynika to z różnego stopnia dojrzałości uczniów na różnych poziomach edukacji i konieczności dostosowania efektów kształcenia do ich wieku.

Ciekawe jest zjawisko określania wielu różnych efektów kształcenia przez niektóre kraje (np. Estonia, Hiszpania, Rumunia, Finlandia, Słowenia, a także Polska), co według autorów raportu służy ciągłości i progresji między wszystkimi poziomami edukacji. Niestety, z raportu wynika, że progresja uzyskana w niektórych kategoriach efektów kształcenia często nie występuje w pozostałych kategoriach. Programy nauczania zawierają elementy przedsiębiorczości, ale efekty kształcenia nie są wystarczająco uporządkowane i zaplanowane, aby zapewnić ich kontynuację w ramach uczenia się przez całe życie. Gdy przedsiębiorczość jest nauczana jako ścieżka międzyprzedmiotowa, powiązania między przedmiotami uwzględniającymi treści z zakresu 
przedsiębiorczości są jeszcze bardziej ograniczone i trudno o połączenie efektów kształcenia w jedno spójne doświadczenie edukacyjne (Eurydice 2016).

Pozytywne przykłady udanej progresji kształcenia dotyczą głównie krajów, w których zadbano o opracowanie długofalowych programów w podziale na różne poziomy nauczania. W Norwegii przedmiot przedsiębiorczość i rozwijanie działalności gospodarczej bazuje na progresywnym budowaniu umiejętności od opisu procesu opracowywania produktu (klasa pierwsza szkoły średniej drugiego stopnia) do dalszego rozwoju pomysłu biznesowego w klasie drugiej. Podobne przykłady progresji można też wskazać w Wielkiej Brytanii (Szkocja), gdzie cel polegający na "zapoznaniu się z narzędziami, które pobudzają przedsiębiorczość i oddziałują na gospodarkę" jest realizowany aż na pięciu poziomach kształcenia (Eurydice 2016).

Warto przypomnieć, że nie wszystkie kraje prowadzą obowiązkową edukację w zakresie przedsiębiorczości i część analizowanych efektów kształcenia nie jest dostępna dla wszystkich uczniów, ale tylko dla tych, którzy wybrali przedmiot (lub przedmioty) obejmujący swym zakresem przedsiębiorczość.

\section{Narzędzia dydaktyczne stosowane w edukacji w zakresie przedsiębiorczości}

\section{Programy szkolne i metody nauczania}

Raport Eurydice podkreśla, że skuteczne nauczanie przedsiębiorczości nie jest możliwe za pomocą tradycyjnych metod dydaktycznych (Eurydice 2016). W tej sytuacji szczególnie ważne jest umożliwienie uczniom podejmowania działań praktycznych o charakterze przedsiębiorczym, a tradycyjne szkoły nie są do końca przygotowane na wyzwania tego typu. Dotyczy to również nauczycieli, którzy rzadko mają doświadczenia z własnej działalności gospodarczej (Sawiński 2011) i przygotowanie ich do roli nauczyciela przedsiębiorczości może stanowić bardzo trudne zadanie.

Warto podkreślić, że wiele krajów, w tym Polska, pozostawia szkołom i nauczycielom znaczną autonomię $w$ wyborze metod nauczania. W ponad połowie krajów obowiązuje niewiele zaleceń dotyczących metod nauczania przedsiębiorczości lub występuje zupełny ich brak. Wytyczne dla szkół pod- 
stawowych i średnich opracowano zaledwie w 12 systemach edukacji, a w pięciu nauczanie odbywa się na podstawie odrębnych strategii skoncentrowanych na temacie przedsiębiorczości (we Wspólnocie Niemieckojęzycznej Belgii, w Estonii, Bośni i Hercegowinie, Czarnogórze i Macedonii). Estońska strategia nauczania przedsiębiorczości "Bądź przedsiębiorczy!" zawiera zalecenia dotyczące dydaktyki. Wytyczne dotyczące metod są najczęściej formułowane dla szkół średnich drugiego stopnia, gdyż na tym poziomie najczęściej naucza się przedsiębiorczości. Takie ogólne wytyczne znajdują się w polskiej podstawie programowej do przedmiotu podstawy przedsiębiorczości w części zatytułowanej „Warunki i sposób realizacji” (Rachwał i in. 2018), niemniej w Polsce przyjmuje się, że szczegóły dotyczące stosowanych metod formułowane są w szkolnych programach nauczania, które są bardziej szczegółowe niż podstawa programowa i dostosowane do lokalnych uwarunkowań. Najczęściej takie szczegółowe wytyczne formułowane są przez autorów poradników metodycznych dla nauczycieli (zob. Makieła, Rachwał 2002).

Raport Eurydice wskazuje, że w Europie wyróżnia się cztery rodzaje metod dydaktycznych najczęściej pojawiających się w zaleceniach krajowych stosowanych w nauczaniu przedsiębiorczości:

$\rightarrow$ metody aktywizujące,

$\rightarrow$ praca w projektach/projekty szkolne,

$\rightarrow$ uczenie się poprzez doświadczenie,

$\rightarrow$ zajęcia pozaszkolne prowadzone we współpracy ze społecznością lokalną i z przedsiębiorstwami (Eurydice 2016).

Najbardziej rozpowszechnione metody to te aktywizujące uczniów, np. poprzez wizyty w przedsiębiorstwach (Łotwa, Austria, Serbia). Wprowadza się je także obecnie do nowej podstawy programowej w Polsce (Rachwał i in. 2018). Jednak z punktu widzenia Komisji Europejskiej najbardziej pożądane metody pozwalają uczniom na zgromadzenie doświadczeń praktycznych w dziedzinie przedsiębiorczości i kształtują postawy przedsiębiorcze. Raport Eurydice, nawiązując do wezwania Komisji Europejskiej, aby państwa członkowskie zapewniły uczniom przynajmniej jedno doświadczenie praktyczne w dziedzinie przedsiębiorczości w ramach kształcenia obowiązkowego, przedstawia kilka najważniejszych modeli zaobserwowanych w europejskich programach nauczania (Komunikat KE 2012). Są to: 
$\rightarrow$ praca $w$ projektach ( $w$ dziedzinie przedsiębiorczości),

$\rightarrow$ wyzwania praktyczne i społeczne - rozwiązanie konkretnych problemów w środowisku pracy wskazanych przez przedsiębiorców lub instytucje z zewnątrz czy rozwiązanie konkretnych problemów występujących w środowisku lokalnym,

$\rightarrow$ tworzenie miniprzedsiębiorstw - założenie i prowadzenie przez pewien czas przedsiębiorstwa przez uczniów,

$\rightarrow$ uczniowskie inicjatywy mikrofinansowania - pomysły i projekty typu crowdfunding, nastawione na osiągnięcie zysku.

Zdobycie praktycznego doświadczenia w zakresie przedsiębiorczości poprzez pracę w projektach jest najbardziej rozpowszechnionym modelem, a mimo to jest uwzględnione w szkolnych programach nauczania tylko kilkunastu krajów (mniej niż jedna trzecia badanych systemów edukacji). Praca w projektach dotyczących przedsiębiorczości rzadko jest realizowana na wszystkich trzech poziomach kształcenia (tylko w trzech krajach: Bułgaria, Bośnia i Hercegowina oraz Czarnogóra). W Danii projekty dotyczące przedsiębiorczości są realizowane wyłącznie w ramach szkolnictwa zawodowego. Warto więc przyjrzeć się bliżej kilku krajom, które ten typ kształcenia zapewniają. I tak w Finlandii działa projekt "Ja i moje miasto", w ramach którego w symulacji miniaturowego miasta uczniowie (12-13 lat) pracują w określonych zawodach i wypełniają obowiązki obywatelskie. Uczestnictwo w projekcie nie jest obowiązkowe, ale w zasadzie wszyscy uczniowie klas szóstych biorą w nim udział. W Norwegii uczniowie w tym samym wieku mają z kolei możliwość wyboru spośród przedmiotów fakultatywnych, które obejmują m.in. praktyczne działania przedsiębiorcze. W ramach przedmiotu umiejętności potrzebne w pracy zawodowej uczniowie tworzą konkretny produkt (Eurydice 2016).

Drugim najbardziej rozpowszechnionym sposobem zdobycia doświadczenia w zakresie przedsiębiorczości jest tworzenie miniprzedsiębiorstw lub przedsiębiorstw młodzieżowych. Praktyki tego typu są prowadzone zwykle z udziałem starszych uczniów, a w szkołach podstawowych stosuje się je jedynie w Hiszpanii. W szkołach średnich drugiego stopnia możliwość organizowania przedsiębiorstw uczniowskich jest przewidziana w 16 krajach. Tworzenie miniprzedsiębiorstw odbywa się często poprzez współpracę z instytucjami, które specjalizują się w tego typu działaniach, np. w Danii - Duńska Fundacja Przedsiębior- 
czości. W kilku krajach praktyki w postaci działających firm uczniowskich są bardzo popularne. W Finlandii w roku szkolnym 2013/2014 powstało 1,3 tys. przedsiębiorstw młodzieżowych, w których przeszkolono ponad 4 tys. uczniów. W kolejnym roku szkolnym 20 proc. szwedzkich uczniów wzięło udział w podobnych działaniach w ramach programu „Firma", a w Estonii działały 42 miniprzedsiębiorstwa w szkołach średnich pierwszego stopnia oraz 200 w szkołach średnich drugiego stopnia. W Austrii w szkolnictwie zawodowym działa ponad tysiąc tego typu firm. W Polsce ta idea realizowana jest fakultatywnie przez szkoły, głównie w ramach programu edukacyjnego Fundacji Młodzieżowej Przedsiębiorczości.

W Holandii, gdzie obowiązuje autonomia programowa, niektóre szkoły specjalizują się i określają jako enterprenasium, co oznacza placówkę, w której uczniowie mogą prowadzić własne przedsiębiorstwo, albo jako technasium, czyli szkołę łączącą technologię z innowacyjną przedsiębiorczością, często poprzez współpracę z klientami zewnętrznymi. Przedsiębiorstwo młodzieżowe działa przez określony czas, najczęściej jeden rok szkolny. Jest prowadzone zgodnie z obowiązującymi zasadami rynkowymi, regulującymi podstawowe kwestie finansowe i organizacyjne, oraz zasadami dotyczącymi wydajności i opłacalności działań. Uczniowie realizują wszystkie podstawowe czynności w firmie, są odpowiedzialni za zakupy, sprzedaż, promocję, fakturowanie, księgowość itp. Miniprzedsiębiorstwo nie posiada faktycznej osobowości prawnej, ale może być prowadzone na zasadzie różnych form prawnych i przybierać różne modele organizacyjne.

Uczniowie prowadzą działalność gospodarczą najczęściej nieodpłatnie, choć w przypadku niektórych krajów mogą otrzymywać niewysokie wynagrodzenie, w zależności od modelu organizacyjnego przedsiębiorstwa i poczynionych uzgodnień, np. ustalonej kwoty, której sprzedaż i wypracowane zyski nie mogą przekroczyć (w przeciwnym wypadku stosuje się przepisy podatkowe). Z kolei pracownicy szkoły w przypadku niektórych krajów mogą otrzymywać dodatkowe wynagrodzenie za taką działalność (zgodnie z odpowiednimi przepisami, np. we Włoszech to krajowe układy zbiorowe i przepisy regulujące łączenie urzędów), jednak według częściej występującego modelu nie mogą być zatrudniani w przedsiębiorstwach uczniowskich, a praca z uczniami w tego typu projektach nie wiąże się ze zmniejszeniem ich pensum dydaktycznego. 
Wyzwania praktyczne i społeczne oraz uczniowskie inicjatywy mikrofinansowania są w programach nauczania na razie zjawiskiem rzadkim (Eurydice 2016). Jedyny przykład inicjatywy mikrofinansowania znaleziono w Austrii - jest to program „Innowacyjna młodzież" (Jugend Innovativ).

\section{Programy realizowane po lekcjach i poza szkołą}

Europejscy uczniowie gromadzą również praktyczne umiejętności w dziedzinie przedsiębiorczości w trakcie zajęć pozalekcyjnych oraz działań organizowanych przez instytucje spoza szkoły. Kontakt z rzeczywistością pozaszkolną to jeden ze sposobów kształtowania postaw przedsiębiorczych wśród uczniów.

Z raportu Eurydice (2016) wynika, że ważną rolę w tej dziedzinie odgrywa międzynarodowa organizacja pozarządowa Junior Achievement oraz jej organizacje członkowskie w poszczególnych krajach (w Polsce pod nazwą Fundacja Młodzieżowej Przedsiębiorczości). W niektórych krajach organizacja pozyskała akredytację ministerstwa edukacji (w Polsce, a także w Czechach, Norwegii, Szwecji i Serbii) lub otrzymuje na swoje działania dotacje rządowe (Eurydice 2016). Z kolei we Wspólnocie Flamandzkiej Belgii, Bułgarii, Estonii, Grecji i na Łotwie programy opracowane przez Junior Achievement są realizowane w ramach standardowych programów nauczania (Eurydice, 2016). W Estonii Fundacja Enterprise Estonia corocznie organizuje konkurs wniosków na projekty dotyczące rozwijania postaw przedsiębiorczych wśród młodzieży. W Wielkiej Brytanii działają organizacje charytatywne, np. MyBank, który uczy młodych ludzi, jak należy zarządzać swoimi pieniędzmi i zakładać własne firmy, oraz Young Enterprise, która proponuje młodzieży udział w programach umożliwiających im poznanie świata biznesu i pracy zawodowej.

W ramach zajęć pozalekcyjnych są też organizowane konkursy związane z przedsiębiorczością, np. austriacki konkurs "Następne pokolenie", w którym uczniowie szkół zawodowych konsultują swoje pomysły biznesowe z trenerami biznesu, czy brytyjski konkurs "Tycoons in Schools", umożliwiający uczniom założenie i prowadzenie działalności gospodarczej. Praktyczne zajęcia dodatkowe są często inicjowane na szczeblu regionalnym (np. w Hiszpanii) lub lokalnym (Eurydice 2016).

Wiele programów tego typu jest realizowanych w krajach europejskich w ramach programu Erasmus+. Przykładowo w konsorcjum 
partnerów z Węgier, Niemiec i Polski wypracowano program rozwoju 10 kompetencji przedsiębiorczych w ramach zajęć pozalekcyjnych (Kilar i in. 2016). Jak wskazała faza pilotażowa realizacji programu, jego wdrożenie może przyczynić się do lepszego rozwoju postaw przedsiębiorczych młodzieży, szczególnie tej zagrożonej bezrobociem i niepodejmującej dalszej edukacji (Kilar i in. 2017).

Niestety, nadal w bardzo niewielu krajach doświadczenie praktyczne w zakresie przedsiębiorczości stanowi stały i obowiązkowy element programu nauczania. Nowa podstawa programowa kształcenia ogólnego w Polsce, zawierająca takie doświadczenia praktyczne jak np. ćwiczenia terenowe w przedsiębiorstwach, nie tylko w ramach przedmiotu podstawy przedsiębiorczości, lecz także geografii, jako integralny element procesu kształcenia, daje szansę na poprawę w tym zakresie (Rachwał i in. 2018).

\section{Podsumowanie}

Dane Eurobarometru z 2014 r. pokazują, że większość młodych ludzi w UE (w wieku 15-29 lat) nie chce uruchamiać własnej działalności gospodarczej, a ponad 20 proc. chciałoby, ale uważa to za zbyt trudne (Eurobarometr 2014, cyt. za Eurydice 2016). W tej sytuacji wydaje się, że w dziedzinie nauczania przedsiębiorczości w szkołach w Europie cały czas pozostaje wiele do zrobienia. Kształtowanie kompetencji kluczowej w warunkach szkolnych, w ramach przedmiotów obowiązkowych, nadal stwarza liczne problemy dydaktyczne i organizacyjne, a nawet prawne (np. możliwość zakładania firm szkolnych i zatrudniania w nich uczniów). Nauczanie przedsiębiorczości okazuje się trudniejsze niż tradycyjnych przedmiotów szkolnych, a włączenie przedsiębiorczości do grona kompetencji kluczowych było zapewne bardzo pomocne, lecz - jak się wydaje - niewystarczające.

Być może odpowiedzią na niekompatybilność i rozproszenie efektów kształcenia oraz trudności w zapewnieniu dostępu do doświadczenia praktycznego $\mathrm{w}$ dziedzinie przedsiębiorczości jest opracowanie odrębnej strategii krajowej koncentrującej się na tej dziedzinie. Powstanie i realizacja takiej strategii zapewniają bardziej spójne i kompleksowe podejście do nauczania przedsiębiorczości. Strategie przeważnie uwzględniają warunki konieczne do wdrażania nauczania przedsiębiorczości, w tym współpracę międzyresortową, tworzenie partnerstw, angażowanie otoczenia społecznego i biznesu, a także wdrażają pro- 
cedury monitorowania realizowanych działań. Odrębne strategie są realizowane głównie w Europie Północnej (Finlandia, Szwecja, Norwegia, Estonia) oraz w regionie Bałkanów Zachodnich.

Drugie źródło inspiracji to niewątpliwie inicjatywy podejmowane przez instytucje pozaszkolne. Można więc mówić o szerokim włączeniu się w kształtowanie kompetencji przedsiębiorczych u młodzieży przez różne podmioty, w tym instytucje rządowe, samorządowe i organizacje pozarządowe (Borowiec-Gabryś, Kilar, Rachwał 2018; Rachwał i in. 2018). Potrzeba takich działań dotyczy zarówno Polski, jak i większości krajów w Europie. Pozostaje więc brać przykład z ciekawych doświadczeń krajów, które te rozwiązania już u siebie realizują. 


\section{Bibliografia}

$\rightarrow$ Borowiec-Gabryś, M., Kilar, W., Rachwał, T. (2018), Przedsiębiorczość jako kompetencja przyszłości [w:] S.M. Kwiatkowski (red.), Kompetencje przyszłości, Warszawa: Fundacja Rozwoju Systemu Edukacji, s. 70-89.

$\rightarrow$ Education, Audiovisual and Culture Executive Agency, Eurydice (2012), Entrepreneurship Education at School in Europe. National Strategies, Curricula and Learning Outcomes, Bruksela: Europejskie Biuro Eurydice.

$\rightarrow$ Kilar, W., Kurek, S., Osuch, W., Świętek, A., Rachwał, T. (2016), Koncepcja oceny i kształtowania postaw przedsiębiorczych na podstawie narzędzi wypracowanych w ramach projektu RLG, „Przedsiębiorczość - Edukacja”, nr 12, s. 426-443.

$\rightarrow$ Kilar, W., Kurek, S., Osuch, W., Świętek, A., Rachwał, T. (2017), Developing Entrepreneurial Competencies of the RLG Project Participants - Applicability of Assessment Tools and Results of Pilot Studies, "Przedsiębiorczość - Edukacja”, nr 13, s. 314-329.

$\rightarrow$ Komisja Europejska/EACEA/Eurydice (2016), Entrepreneurship Education at School in Europe. (Nauczanie przedsiębiorczości w szkołach w Europie) Raport Eurydice, Luksemburg: Urząd Publikacji Unii Europejskiej, Bruksela/Warszawa: Europejskie Biuro Eurydice/Fundacja Rozwoju Systemu Edukacji.

$\rightarrow$ Makieła, Z., Rachwał, T. (2002), Podstawy przedsiębiorczości - poradnik metodyczny dla nauczycieli liceum ogólnokształcqcego, liceum profilowanego i technikum, Warszawa: Wydawnictwo Nowa Era.

$\rightarrow$ Rachwał, T., Kilar, W., Kawecki, Z., Wróbel, P. (2018), Edukacja w zakresie przedsiębiorczości w wychowaniu przedszkolnym, szkole podstawowej i szkołach średnich w świetle nowej podstawy programowej, „Przedsiębiorczość - Edukacja", nr 14, s. 389-424.

$\rightarrow$ Rachwał, T., Kurek, S. Boguś, M. (2016), Entrepreneurship Education at Secondary Level in Transition Economies: A Case of Poland „Entrepreneurial Business and Economics Review", nr 4 (1), s. 61-81. 
$\rightarrow$ Wach, K. (2013), Edukacja na rzecz przedsiębiorczości wobec współczesnych wyzwań cywilizacyjno-gospodarczych, „Przedsiębiorczość - Edukacja”, nr 9, s. 246-257. 


\section{Netografia}

$\rightarrow$ Fundacja Młodzieżowej Przedsiębiorczości, Młodzieżowe miniprzedsiębiorstwo - o programie, miniprzedsiebiorstwo.junior.org.pl (dostęp: 30.01.2019).

$\rightarrow$ Płatos, B. (2018), Przedsiębiorczość w praktyce: firma na terenie szkoły, eurydice.org.pl/wp-content/uploads/2018/11/firma.pdf (dostęp: 20.11.2018).

$\rightarrow$ Sawiński, J.P. (2011), Jak w szkole uczyć przedsiębiorczości? Portal edunews.pl, edunews.pl/badania-i-debaty/opinie/1648-jak-w-szkole-uczyc-przedsiebiorczosci (dostęp: 15.11.2018). 


\section{Edukacja w zakresie przedsiębiorczości we Francji ${ }^{1}$}

Sławomir Dorocki, Paweł Brzegowy, Marek Ziarko

W niniejszym rozdziale przedstawiono miejsce edukacji w zakresie przedsiębiorczości w systemie szkolnym Francji. Interdyscyplinarne kształtowanie ducha przedsiębiorczości odbywa się na różnych szczeblach edukacji, jednakże w sposób obowiązkowy jedynie na studiach. W tekście zarysowano główne cele i metody kształcenia w zakresie edukacji w przypadku zarówno kursu odkrywanie zawodu (decouverte professionnelle), jak i ścieżki edukacyjnej: odkrywanie drogi zawodowej i edukacyjnej (parcours de découverte des métiers et des formations). Na tle tej problematyki przedstawiono najważniejsze kwestie i dylematy w zakresie nauczania przedsiębiorczości we Francji.

\section{_ Słowa kluczowe: \\ duch przedsiębiorczy \\ edukacja w zakresie przedsiębiorczości \\ Francja \\ nauczanie przedsiębiorczości \\ postawa przedsiębiorcza}

1. Poniższe opracowanie powstało jako uzupełnienie i kompilacja artykułów: S. Dorocki, P. Brzegowy (2014), Miejsce przedsiębiorczości w systemie edukacyjnym Francji i jej wpływ na aktywizację gospodarczq regionów. O idei l'esprit d'entreprise, "Horyzonty Wychowania", nr 13 (26), s. 287-302; S. Dorocki, P. Brzegowy (2014), Uwarunkowania przestrzennego zróżnicowania postaw przedsiębiorczych we Francji, „Przedsiębiorczość - Edukacja”, nr 10, s. 149-163 oraz S. Dorocki, M. Ziarko, R. Boutron (2015), Planowanie kariery zawodowej w procesie kształcenia we Francji, „Przedsiębiorczość - Edukacja”, nr 11, s. 377-390. 


\section{Entrepreneurship education in France}

Sławomir Dorocki, Paweł Brzegowy, Marek Ziarko

The following chapter presents the place of entrepreneurship education in the school system of France. Interdisciplinary shaping the entrepreneurial spirit is held at different levels of learning, however, on a mandatory basis only for the college. The text outlined the main goals and methods of education in the field of education, both in the case of the course: discovering the profession (decouverte professionnelle), and the educational path: discovering the professional and educational path (parcours de découverte des métiers et des formations). The most important issues and dilemmas in the field of entrepreneurship education in France are presented against this background.

\section{Keywords: \\ enterprising spirit \\ education in entrepreneurship \\ France \\ entrepreneurship education \\ entrepreneurial attitude}




\section{Wstęp}

Około połowy dorosłych Europejczyków uważa, że nie mają wiedzy ani zdolności, aby rozpocząć własną działalność gospodarczą (Le défi de l'éducation entrepreneuriale en France 2017). Istnieje zatem zarówno problem pewności siebie, jak i braku wiedzy oraz umiejętności z zakresu przedsiębiorczości. We Francji tylko 3 proc. przedsiębiorstw rozpoczynających działalność zakładają studenci, podczas gdy w Stanach Zjednoczonych Ameryki Północnej odsetek ten wynosi 11 proc. [(R) evolution 25 ans de transformation de l'écosystème entrepreneurial français]. W obliczu tej rzeczywistości francuski model edukacji w zakresie przedsiębiorczości w ciągu ostatnich lat powoli się zmienia, aby promować ducha przedsiębiorczości wśród nowych pokoleń.

\section{Rozumienie przedsiębiorczości}

\section{w systemie edukacji Francji}

Odnosząc się do problematyki edukacji w zakresie przedsiębiorczości we Francji, należy podkreślić, że podobnie jak w innych państwach tu także trwała dyskusja, czy przedsiębiorczości można nauczyć, a jeśli tak, to jaką formę ma przyjąć jej edukacja (Fayolle 2000, Saporta, Verstraete 2000, Sénicourt, Verstraete 2000, Byrne i in. 2014, Fayolle 2013). Aby odpowiedzieć na to pytanie, należało po pierwsze zdefiniować pojęcie przedsiębiorczości i określić, jakie kompetencje uczniów i studentów składające się na szeroko rozumianą przedsiębiorczość chcemy w toku edukacji kształtować (Borowiec-Gabryś 2018, Piróg 2015, Płaziak, Rachwał 2014). Francuscy autorzy, podobnie jak inni europejscy badacze problemu przedsiębiorczości, zwracali uwagę na brak jednoznacznej jej definicji. Najczęściej uznaje się, że jest to zbiór zachowań, umiejętności i cech wykorzystywanych do zarządzania, organizowania oraz tworzenia przedsiębiorstw $\mathrm{i}$ innowacji, w sytuacjach wymagających podjęcia ryzyka i analizy wielu zmiennych (Bechard 1998; Sénicourt, Verstraete 2000). Przedsiębiorczość zatem odnosi się w ujęciu francuskim bardziej do l'esprit d'entreprise (EE) - ducha przedsiębiorczości, niż do konkretnych umiejętności lub wiedzy (Fayolle, Sénicourt 2005). Jednakże współcześnie we Francji przyjmuje się, że edukacja z zakresu przedsiębiorczości ma charakter zarówno teoretyczny, jak i praktyczny, związany głównie z tworzeniem własnych przedsiębiorstw (Katza 1990). 


\section{Miejsce przedsiębiorczości w systemie edukacyjnym Francji i metody kształcenia}

Popularyzowanie postaw przedsiębiorczych we Francji jest zadaniem Krajowej Komisji ds. Promocji Przedsiębiorczości. W wyniku podjętych przez nią inicjatyw na etapie szkoły średniej (collège) nadano możliwość udziału w kursie decouverte professionnelle, którego zadaniami są: zapoznanie uczniów z uwarunkowaniami życia społeczno-gospodarczego oraz próba określenia ich preferencji zawodowych. Rozszerzona opcja programu obejmuje staż w firmach lub ośrodkach szkoleniowych.

We Francji wskazuje się na potrzebę interdyscyplinarnego podejścia w nauczaniu przedsiębiorczości. Do jej kluczowych celów zaliczono: podniesienie świadomości przedsiębiorczej, kształtowanie umiejętności w obszarach działań na rzecz przedsiębiorczości w celu zachęcania do tworzenia własnego biznesu oraz wspieranie i monitorowanie projektów przedsiębiorczych (Tounés 2003). Współcześnie w nauczaniu przedsiębiorczości we Francji postuluje się rezygnację z tradycyjnego paradygmatu nauki ekonomii (finanse, podatki, marketing itp.) na rzecz rozwijania ducha przedsiębiorczości poprzez realizowanie zadań praktycznych. Celem takich działań jest kreowanie postaw przedsiębiorczych w sytuacji niepewności, rozbudzanie potrzeby podejmowania ryzyka i wykazywania kreatywności oraz inicjatywy. Dzięki tej metodzie uczestnicy kursu mogą w jak najwierniejszy sposób odtworzyć warunki, z którymi spotkają się we współczesnej rzeczywistości gospodarczej. Wśród zalecanych technik nauczania przedsiębiorczości znalazła się metoda projektu, w ramach której zespoły realizują zadania w sposób funkcjonalny. W dążeniu do osiągnięcia założonego celu projektu wykorzystywane są interdyscyplinarne umiejętności uczniów (np. manualne, techniczne, z zakresu zarządzania), współpracujących w ramach wspólnego zadania. Metoda problemowa przyczynia się do wzajemnego uczenia się, wymiany wiedzy i umiejętności między uczestnikami projektu oraz potencjalnymi partnerami (przedsiębiorcami). W ujęciu tym w głównej mierze zwraca się uwagę na potrzebę zapewnienia uczniom dostępu do zasobów i umiejętności innych osób (np. ekspertów). Jak wspomniano powyżej, nauczanie przedsiębiorczości powinno się składać z etapów, na których następowałoby przekazywanie wiedzy i umiejętności potrzebnych do realizacji konkretnych projektów. Dlatego nauczanie przedsiębiorczości podzielono na trzy fazy. Pierwszą jest podniesienie świadomości i rozwój wiedzy ogólnej 
o przedsiębiorczości.Przedsiębiorczość w tym ujęciu odnosi się do zachowań, to znaczy ma stymulować kreatywność, ducha inicjatywy i rozwijać samodzielność. Drugim celem jest specjalizacja studentów w obszarze przedsiębiorczości, aby zachęcić ich do założenia własnej firmy. Ostatnim celem edukacji w zakresie przedsiębiorczości jest monitorowanie uczniów, którzy planują założyć firmę. W praktyce te trzy cele są komplementarne i mogą się nakładać. Zwraca się uwagę, że edukacja w zakresie przedsiębiorczości zależy od rodzaju odbiorców i ich potrzeb. Zaznaczyć należy, że przedsiębiorczość to nie tylko praktyka, lecz także obszar nauki, który może wpływać na postawy, normy i sposób postrzegania wyboru zawodu przez uczniów i studentów (Tounés 2003).

Obowiązkowe kursy z przedsiębiorczości odbywają się tylko w ramach studiów wyższych, jednakże od 2004 r. wprowadzono w trzeciej klasie collège dobrowolny moduł: odkrywanie zawodu (découverte professionnelle). Ma on na celu zapoznanie uczniów z regułami i uwarunkowaniami społeczno-ekonomicznymi świata biznesu. Kurs realizowany w wymiarze trzech godzin tygodniowo ma przygotować młodych ludzi do przyszłej aktywności zawodowej. W trakcie realizowanych zajęć poruszane są następujące tematy: praktyczne zrozumienie realiów i uwarunkowań świata biznesu oraz pracy zawodowej, a także poznanie wymaganych szkoleń i kwalifikacji, które prowadzą do zdobycia określonego zawodu. Uczniowie poznają różne branże i profesje oraz formy organizacji pracy (np. samozatrudnienie). W czasie kursu zapoznają się m.in. $z$ wymaganymi w trakcie prowadzenia własnej działalności drukami i dokumentami, spotykają z profesjonalistami oraz praktykami. Kurs realizowany jest $w$ formie międzyklasowej, a nadzoruje go wielodyscyplinarny zespół edukacyjny (składający się m.in. z nauczycieli, doradców zawodowych, psychologów). Zalecanymi typami zajęć są: analiza dokumentów i pism oraz notatek i informacji zebranych samodzielnie przez uczniów, wywiady ze specjalistami, warsztaty, obserwacje oraz wizyty w przedsiębiorstwach i instytucjach administracji publicznej. Moduł découverte professionnelle może być również realizowany $w$ wymiarze sześciu godzin tygodniowo $z$ większą ilością czasu poświęconego na praktykę ( $w$ firmach, szkołach zawodowych lub w formie staży w ośrodkach szkoleniowych), z dużym naciskiem na realizację wybranego projektu, np. planowanie, założenie i organizacja własnego przedsiębiorstwa. 
Wśród zmian, które zaszły w nauczaniu przedsiębiorczości we Francji po 2008 r., można wskazać położenie większego nacisku na współpracę z przedsiębiorcami oraz kształtowanie ducha przedsiębiorczości kosztem przekazywania suchej wiedzy ekonomicznej. W myśl tej zasady Patrick Rey z Toulouse School of Economics postulował, żeby to przedsiębiorcy stawali się nauczycielami/trenerami (Lavoie 2015). Natomiast kształcenie w zakresie przedsiębiorczości odbywa się w systemie realizacji projektów przy wsparciu różnych podmiotów zewnętrznych (instytucji, przedsiębiorstw, trenerów) (Visot 2013).

\section{Rola doradztwa zawodowego w pobudzaniu przedsiębiorczości}

Innym aspektem działań związanych z pobudzeniem przedsiębiorczości we Francji jest doradztwo zawodowe. Na duże znaczenie takiego doradztwa z punktu widzenia przygotowania młodzieży do dorosłego życia zwraca uwagę wielu autorów (Dziewulak 2013). Orientacja szkolna i zawodowa (orientation scolaire et professionnelle) polega na zaproponowaniu uczniom różnych ścieżek rozwoju zawodowego, które mogą podjąć w zależności od swoich zainteresowań, wyników w nauce oraz cech osobowościowych. Poprzez wybór zawodu rozumie się proces, ciąg decyzji, który zaczyna się we wczesnym dzieciństwie i trwa przez całe życie. Za kluczowy okres w procesie orientacji uznaje się ostatni rok collège, kiedy to uczeń decyduje o wyborze szkoły średniej drugiego stopnia. Od liceum zaczyna się już bowiem kształcenie zawodowe, a młody człowiek musi być gotowy podjąć decyzje dotyczące swojej przyszłości. Dlatego też wszyscy uczniowie gimnazjum i liceum uczestniczą w programie edukacyjnym, tzw. ścieżce odkrywania drogi zawodowej i edukacyjnej (parcours de découverte des métiers et des formations), którego celem jest przedstawienie im w miarę szerokiego spektrum dostępnych zawodów oraz dróg kształcenia. Ścieżkę opracowują: dyrektor placówki oświatowej przy udziale całego grona pedagogicznego oraz instytucje zewnętrzne. Na etapie gimnazjum wspomniana ścieżka jest jedną z dróg nabywania wiadomości i kompetencji wspólnych dla każdej aktywności zawodowej. Są to zatem kompetencje społeczne i obywatelskie. Kształtowane są również wśród uczniów takie cechy jak samodzielność i aktywność. Uczniowie zostają objęci ścieżką w drugim roku kształcenia - według nazewnictwa francuskiego jest to klasa piąta, cinquième. Wtedy też zaczyna się stopniowe prezentowanie im rozmaitych 
profesji oraz sposobów kształcenia. W pierwszym roku program obejmuje wizyty w przedsiębiorstwach i zakładach pracy oraz spotkania i wywiady z profesjonalistami z różnych dziedzin, pozwalające uczniom zapoznać się z wieloma zawodami i branżami. W roku drugim (klasa quatrième) uczniowie poznają istniejące drogi kształcenia - spędzają jeden dzień w liceum, Centrum Kształcenia Zawodowego (Centre de formation d'apprentis, CFA) lub innej placówce edukacyjnej. Trzeci rok programu przypada na ostatnią klasę gimnazjum (troisième). Wówczas przewiduje się m.in. „obserwację środowiska pracy zawodowej”. Każdy uczeń w trakcie nauki w gimnazjum spędza co najmniej 10 dni w jakimś przedsiębiorstwie. Wszyscy uczniowie odbywają również zindywidualizowane rozmowy orientacyjne. Uczniowie mogą też skorzystać z opcji fakultatywnej odkrywania zawodów (découverte professionnelle) w wymiarze trzech lub sześciu godzin tygodniowo. Opcja fakultatywna trzygodzinna, tzw. DP3, jest narzędziem uzupełniającym kulturę ogólną uczniów i pogłębiającym znajomość świata zawodowego o aspekty ekonomiczne i społeczne. Zajęcia w ramach DP3 są przygotowywane i prowadzone przez zespół animatorów z wielu dziedzin: nauczycieli gimnazjalnych i licealnych, doradców zawodowych itp. Mogą one obejmować m.in.: wywiady i spotkania z profesjonalistami przedstawiającymi swój zawód lub ze starszymi uczniami i studentami opowiadającymi o swych wyborach edukacyjnych, wyszukiwanie informacji i analizę dokumentów, tworzenie raportów i dokumentacji na podstawie zebranych materiałów, wizyty, obserwacje i staże w przedsiębiorstwach, administracji, warsztatach, zakładach produkcyjnych oraz laboratoriach, a także tworzenie reportaży na temat zawodów, przedstawianie zdobytych doświadczeń na forum klasy, udział w panelach dyskusyjnych. Moduł sześciogodzinny odkrywania zawodów, DP6, został skonstruowany na podstawie tych samych zasad co opcja DP3, ale przewidziano w nim więcej czasu na poznanie środowiska zawodowego: przedsiębiorstwa, liceum zawodowego lub też CFA. Jest on przeznaczony dla uczniów, którzy zdecydowali już, że po ukończeniu gimnazjum chcą podjąć naukę zawodu. Licealista może skorzystać ze wsparcia spersonalizowanego (accompagnement personnalisé) - dwie godziny zajęć tygodniowo mentoringu i korekcji obranej drogi edukacyjnej. Pierwsza klasa liceum (we Francji nazywana drugą, deuxième) to etap, kiedy uczeń określa swoje cele i wybiera interesujące go dziedziny wiedzy oraz powiązane $z$ nimi metody. Jest $w$ ten sposób wspomagany $w$ ukierunkowaniu na 
wybór matury i studiów wyższych. Ma do dyspozycji dwie godziny tygodniowo wsparcia spersonalizowanego w celu opracowania projektu kształcenia i orientacji. W klasie drugiej (zwanej pierwszą, première) każdy uczeń spędza dzień na wyższej uczelni: uniwersytecie, w uniwersyteckim instytucie technologicznym (IUT), pomaturalnym studium technicznym (STS) lub studium przygotowującym do wielkich szkół (CPGE). Jest to początek przygotowania do orientacji aktywnej. W klasie końcowej (terminale) rada klasowa wydaje na koniec pierwszego trymestru swoją opinię i formułuje zalecenia odnośnie do intencji ucznia w kwestii kształcenia pomaturalnego.

\section{Specyfika nauczania przedsiębiorczości}

Francuska szkoła od kilkunastu lat jest sceną inicjatyw prowadzonych przez nauczycieli i różne zewnętrzne podmioty zaangażowane w promowanie przedsiębiorczości. Brak jasnych wytycznych zawartych w oficjalnych programach daje możliwość podejmowania różnorodnych działań, stanowiąc również źródło krytyki (Verzat i in. 2017). Nauczyciele kwestionują promocję działań, których zadaniem jest przygotowanie uczniów do funkcjonowania w świecie liberalnego przedsiębiorstwa opartego na indywidualnym sukcesie oraz nierówności społecznych, a nawet się im sprzeciwiają (Tanguy 2016). Podczas gdy inni zauważają szansę zerwania ze sztywnością systemu edukacji poprzez eksperymentowanie z nowymi metodami nauczania, starając się przybliżyć młodym ludziom współczesne problemy społeczne.

Przedsiębiorczość postrzegana jako duch przedsiębiorczości rozumiana jest jako pragmatyczny i twórczy sposób postępowania mający na celu rozwój potencjału ludzkiego. Dlatego przeciwstawia się analitycznemu i obiektywnemu wnioskowaniu naukowemu. W ten sposób stoi w opozycji do odkrycia uniwersalnych praw natury, które są podstawą wiedzy przekazywanej przez szkołę. Ten przedsiębiorczy sposób myślenia i działania musi być zatem nauczany w sposób odmienny od tradycyjnej wiedzy szkolnej. Przedsiębiorczości uczy się poprzez zajęcia praktyczne: gry, symulacje, eksperymenty, projekty przy wykorzystaniu empatii i refleksyjności. Ten sposób kształcenia ma wiele punktów wspólnych z aktywnymi metodami nauczania ucieleśnionymi przez "nową edukację" (Sarasvathy, Venkataraman 2011). W przypadku metody projektów w edukacji w zakresie przedsiębiorczości wyróżnia się rzeczywiste potrzeby innowacyjne z dużym udziałem niepewności 
w stosunku do wyniku. A zatem ryzyko i obowiązki w przypadku projektów wykraczają poza to, co zwykle odbywa się na innych kursach szkolnych (Verzat 2012). Kształcenie powinno zatem koncentrować się na konkretnych potrzebach i problemach. Podejście to ma na celu rozwój ducha przedsiębiorczości w szerokim jego znaczeniu zamiast samej symulacji tworzenia firmy w ścisłym tego słowa znaczeniu. Uznaje się, że działania te mają również pozytywny wpływ na motywację uczniów do pracy w szkole oraz wpływają na ich zachowanie w trudnych sytuacjach (Gingras i in. 2016). Innymi pozytywnymi efektami pracy projektowej w rzeczywistych warunkach gospodarczych są wzrost aktywności dzięki samodzielnemu uczeniu się (Jore 2012; Verzat i in. 2016) i wzmacnianie samooceny (Moberg, Vestergaard 2014).

Wprowadzenie przedsiębiorczości do szkół, niezależnie od formy nauczania, wymusiło uruchomienie aktywnych form nauczania stymulujących zaangażowanie ucznia i podmiotów spoza szkoły. Wyzwaniem dla nauczyciela przedsiębiorczości jest mobilizacja uczniów i pozostawienie im wystarczającej swobody. Nauczyciel staje się bardziej trenerem (coachem) niż wykładowcą (Verzat, Gaujard 2009). Zachodzi zatem konieczność ścisłej współpracy pomiędzy uczniami a światem biznesu, który to kontakt jest istotniejszy dla rozwoju przedsiębiorczości słuchaczy niż sama edukacja (Maunaye, Poisson 2017). Edukacja przedsiębiorcza pojawia się tylko jako punkt węzłowy łączący podmioty instytucjonalne, edukacyjne ( $w$ tym rozwój osobisty) i zawodowe. Samorealizacja uczniów wymusza indywidualne podejście do każdego ucznia, co stawia nauczycieli w obliczu nowych wyzwań (Dubois, Terrala 2017). Spotyka się to ze sprzeciwem nauczycieli przyzwyczajonych do edukacji podręcznikowej (Sam, Van der Sijde 2014; Fayolle, Verzat 2009) i akademickiej formy nauczania (Pepin 2017). Dodatkowo nauczanie przedsiębiorczości spotyka się z krytyką w kwestii przekazywanych idei: poszukiwania zysku (Tanguy 2016) lub sugerującym konieczność odniesienia sukcesu ekonomicznego (Ehrenberg 1998; Verzat, Toutain 2014). Uznaje się, że jest to głównie wynik nauczania przedmiotu przez osoby niewykazujące postaw przedsiębiorczych we własnym życiu (Gingras i in. 2015).

\section{Podsumowanie}

Pomimo tych krytycznych uwag należy uznać, że edukacja w zakresie przedsiębiorczości we Francji rozwija się we właściwym kierunku. Mimo 
ciągłego braku obowiązkowych kursów z zakresu przedsiębiorczości na wszystkich etapach edukacji w szkole średniej i gimnazjum uczniowie zapoznawani są z głównymi zasadami funkcjonowania świata biznesu. Kształtowanie ducha przedsiębiorczości odbywa się natomiast w ramach dodatkowych kursów, które w dużej mierze realizowane są w formie aktywnych zajęć w postaci projektów. Godne naśladowania są również: aspekt współpracy szkół z podmiotami zewnętrznymi oraz indywidualne podejście do ucznia. Niezależnie od tego, czy są to kursy odkrywania zawodu, czy zajęcia z doradztwa zawodowego, stanowią one podstawę do rozwijania aktywnej postawy zawodowej w dorosłym życiu absolwentów. 


\section{Bibliografia}

$\rightarrow$ Bechard, J.P. (1998), L'enseignement en entrepreneurship à travers le monde: validation d'une typologie, „Management International”, nr 3 (1), s. 25-34.

$\rightarrow$ Borowiec-Gabryś, M., Kilar, W., Rachwał, T. (2018), Przedsiębiorczość jako kompetencja przyszłości, [w:] S. Kwiatkowski (red.), Kompetencje przyszłości, Seria Naukowa, t. 3, Warszawa: Fundacja Rozwoju Systemu Edukacji, s. 68-89.

$\rightarrow$ Byrne, J., Fayolle, A., Toutain, O. (2014), Entrepreneurship education : what we know and what we need to know [w:] E. Chell, M. Karatas-Özkan (red.), Handbook of Research on Small Business and Entrepreneurship, Cheltenham: Edward Elgar Publishing, s. 261-288.

$\rightarrow$ Dorocki, S., Brzegowy, P. (2014), Miejsce przedsiębiorczości w systemie edukacyjnym Francji i jej wpływ na aktywizację gospodarczą regionów. O idei l'esprit d'entreprise, „Horyzonty Wychowania”, nr 13 (26), s. 287-302.

$\rightarrow$ Dorocki, S., Brzegowy, P. (2014), Uwarunkowania przestrzennego zróżnicowania postaw przedsiębiorczych we Francji, "Przedsiębiorczość - Edukacja”, nr 10, s. 149-163.

$\rightarrow$ Dorocki, S., Ziarko, M., i Boutron, R. (2015), Planowanie kariery zawodowej w procesie kształcenia we Francji, „Przedsiębiorczość - Edukacja”, nr 11, s. 377-390.

$\rightarrow$ Dubois, F., Terral, P. (2017), Des jeunes plus ou moins prêts à devenir entrepreneurs: De l'engagement sportif amateur à la création d'entreprises de tourisme sportif, "Agora débats/jeunesses”, nr 75 (1), s. 103-116, doi: 10.3917/agora.075.0103.

$\rightarrow$ Dziewulak, D. (2013), Doradztwo edukacyjno-zawodowe w szkolnictwie zawodowym w Polsce i w wybranych państwach Unii Europejskiej, "Analizy", nr 4 (93), s. 1-8.

$\rightarrow$ Ehrenberg, A. (1998), La fatigue d'être soi. Dépression et société, Paris: Odile Jacob.

$\rightarrow$ Fayolle, A. (2000), L'enseignement de l'entrepreneuriat dans le système éducatif supérieur français : un regard sur la situation actuelle , "Gestion 2000", s. 77-95. 
$\rightarrow$ Fayolle, A. (2013), Personal views on the future of entrepreneurship education, „Entrepreneurship \& Regional Development", nr 7-8 (25), s. 692-701.

$\rightarrow$ Fayolle, A., Verzat, C. (2009), Pédagogies actives et entrepreneuriat: quelle place dans nos enseignements?, „Revue de l'entrepreneuriat", nr 2 (8), s. 1-15.

$\rightarrow$ Fayolle, A., Sénicourt, P. (2005), Peut-on former des entrepreneurs?, „L'Expansion Management Review", nr 116 (1), s. 34-41, doi: 10.3917/emr.116.0034.

$\rightarrow$ Gingras, M., Morin, D., Samson, G. (2015), La pédagogie entrepreneuriale: retombées chez les élèves et les enseignants en formation et en exercice, www.idee.education/wp-content/uploads/2016/05/Samson-Gingras-2015.pdf.

$\rightarrow$ Jore, M. (2012), Apprenance et proactivité: élaboration d'instruments et analyse des liens inter attitudinaux, Thèse de doctorat en sciences de l'éducation sous la direction de Philippe Carré, Université Paris Ouest - Nanterre La Défense, www.theses.fr/2012PA100092.

$\rightarrow$ Katz, J.A. (1990), Longitudinal analysis of self-employment follow-through, „Entrepreneurship And Regional Development”, nr 2, s. 15-25.

$\rightarrow$ Khedri, F. (2016), Étude: des 18-24 ans ont envie de créer leur entreprise, fr.petitsfrenchies.com/62-des-francais-de-18-24-ans-voudraient-creer-leur-entreprise.

$\rightarrow$ Lavoie, M. (2015), Teaching monetary theory and monetary policy implementation after the crisis, "European Journal of Economics and Economic Policies: Intervention", nr 12 (2), s. 220-228.

$\rightarrow$ Le défi de l'éducation entrepreneuriale en France, Huby, 23 août 2017, huby-innovation.com/defi-leducation-entrepreneuriale-france.

$\rightarrow$ Maunaye, E., Poisson, F. (2017), L'action collective des adolescents: premiers pas d'entrepreneurs?, "Agora débats/jeunesses", nr 75 (1), s. 89-101, doi: 10.3917/agora.075.0089.

$\rightarrow$ Moberg, K., Vestergaard, L. (2014), Impact of Entrepreneurship Education in Denmark - 2013, The Danish Foundation for Entrepreneurship - Young Enterprise, Odense (Danemark), http://eng.ffe-ye.dk/media/785771/impact-of-ee-in-denmark-2013.pdf.

$\rightarrow$ Pepin, M. (2017), Le projet entrepreneurial à l'école primaire : tensions inhérentes à son intégration à la forme scolaire, „Agora débats/jeunesses”, nr 75 (1), s. 73-88. doi: 10.3917/agora.075.0073.

$\rightarrow$ Piróg, D. (2015), Kompetencje z zakresu przedsiębiorczości: rozważania teoretyczne i ich ilustracje w obszarze szkolnictwa wyższego, „Przedsiębiorczość - Edukacja", nr 11, s. 364-376.

$\rightarrow$ Piróg, D., Rachwał, T. (2018), Comics as a tool for a narrative approach in early career counselling: theory versus empirical evidence [published on-line], „British 
Journal of Guidance and Counselling", www.tandfonline.com/doi/full/10.1080/ 03069885.2018.1538494 [dostęp 28.02.2019].

$\rightarrow$ Płaziak, M., Rachwał, T. (2014), Kształcenie w zakresie przedsiębiorczości na polskich uniwersytetach na studiach nieekonomicznych (na przykładzie kierunku geografia), „Horyzonty Wychowania”, nr 13 (26), s. 249-266.

$\rightarrow$ Sam, C., Van der Sijde, P. (2014), Understanding the concept of the entrepreneurial university from the perspective of higher education models, "Higher Education", nr 68 (6), s. 891-908.

$\rightarrow$ Saporta, B., Verstraete, T. (2000), Réflexions sur l'enseignement de l'entrepreneuriat dans les composantes en sciences de gestions des universités françaises, "Gestion 2000", s. 97-121.

$\rightarrow$ Sarasvathy, S.D., Venkataraman, S. (2011), Entrepreneurship as method: open questions for an entrepreneurial future , "Entrepreneurship Theory and Practice", nr 35 (1), s. 113-135.

$\rightarrow$ Senicourt, P., Verstraete, T. (2000), Apprendre à entreprendre: typologie à quatre niveaux pour la diffusion d'une culture entrepreneuriale au sein du système éducatif, „Reflets et perspective de la vie économique”, nr 34 (4), s. 131-140.

$\rightarrow$ Tanguy, L. (2016), Enseigner l'esprit d'entreprise à l'école. Le tournant politique des années 1980-2000 en France, Paris: La Dispute.

$\rightarrow$ Tounés, A. (2003), Un cadre d'analyse de l'enseignement de l'entrepreneuriat en France, Cahier de recherche du réseau Entrepreneuriat de l'AUF, s. 1-15.

$\rightarrow$ Verzat, C. (2012), Éduquer l'esprit d'entreprendre. Bilan et questionnements de recherche, Habilitation à diriger des recherches en sciences de gestion, Grenoble: Université Pierre-Mendès-France, www.yumpu.com/fr/document/ view/41768191/eduquer-lesprit-dentreprendre-bilan-et-questionnements-de.

$\rightarrow$ Verzat, C., Gaujard, C., (2009), Expert, conseiller, mentor, confident ou tout à la fois?, „L'expansion entrepreneuriat”, nr 2, s. 6-12.

$\rightarrow$ Verzat, C., O'Shea, N., Jore, M. (2016), Des étudiants heureux et proactifs grâce à l'apprentissage autodirigé, „Entreprendre \& Innover", nr 2 (29), s. 37-48.

$\rightarrow$ Verzat, C., Toutain, O. (2014), Entraîner l'esprit d'entreprendre à l'école, une opportunité pour apprendre à apprendre?, „Cahiers de l'action”, nr 41 (1), s. 7-17.

$\rightarrow$ Verzat, C., Trindade-Chadeau, A., Toutain, O. (2017), Introduction: Promesses et réalités de l'entrepreneuriat des jeunes, „Agora débats/jeunesses”, nr 75 (1), s. 57-72.

$\rightarrow$ Visot, M. (2013), Fleur Pellerin: „Je souhaite créer une école de l'entrepre-neuriat", LeFigaro.fr, 26.08.2013, www.lefigaro.fr/entrepreneur/2013/08/26/ 09007-20130826ARTFIG00434-fleur-pellerin-je-souhaite-creer-une-ecole-de-l-entrepreneuriat.php. 


\section{Netografia}

$\rightarrow \quad(R)$ evolution 25 ans de transformation de l'écosystème entrepreneurial français, EY et ESCP Europe, le 22 septembre 2017, 25e édition du Prix de l'Entrepreneur de l'Année, fondation-entrepreneurs.mma/news/174377/developper-|-146-entrepreneuriat-en-france.htm (dostęp 28.02.2019).

$\rightarrow 20$ ans de succès entrepreneurial en France. Ernst \& Young, 2012, www.ey.com/ Publication/vwLUAssets/Ernst_-_Young_-_20_ans_de_succes_entrepreneurial_en_France/\$FILE/Ernst-Young_20_ans_Entrepreneuriat.pdf (dostęp 28.02.2019).

$\rightarrow$ 2018, l'année de l'entrepreneuriat, www.beboss-portage.com/2018-lannee-de-I-entrepreneuriat (dostęp 28.02.2019). 


\section{Edukacja w zakresie \\ przedsiębiorczości na poziomie \\ akademickim w Republice Korei ${ }^{1}$}

Julita Majczyk

Systemy edukacji na poziomie międzynarodowym są zróżnicowane, zaprojektowane tak, by spełniać oczekiwania stawiane przez otoczenie ekonomiczne, kulturowe czy społeczne. Przykładem zmian w edukacji na poziomie akademickim jest Republika Korei, w której otoczenie polityczne wyznaczyło szkoły przedsiębiorczości, których celem jest wspieranie rozwoju gospodarczego. Jednak uniwersytet nie jest jedyną instytucją promującą działania przedsiębiorcze. W artykule scharakteryzowano wybrane elementy ekosystemu przedsiębiorczości.

\section{__ Słowa kluczowe: \\ edukacja przedsiębiorczości \\ kompetencje \\ konkurencja \\ program nauczania \\ intencja przedsiębiorcza}

1. UE:This project has received funding from the European Union's Horizon 2020 research and innovation programme under the Marie Skłodowska-Curie grant agreement No 734824 . MNiSW: Scientific paper funded from financial sources for science in the years 2017-2020 awarded for the implementation of the international co-financed project. 


\title{
Entrepreneurship education \\ at the tertiary level \\ in the Republic of Rorea
}

Julita Majczyk

Diversified Educational Systems at the international level are designed to meet economic, cultural, or social expectations. The Republic of Korea, where the political environment designated entrepreneurship schools that aim to support economic development, is an example of changes introduced in education at the academic level. However, the university is not the only institution that promotes entrepreneurial activities. The article describes selected elements of the entrepreneurship ecosystem.

\author{
_ Keywords: \\ entrepreneurship education \\ competences \\ competition \\ study program \\ entrepreneurial intention
}




\section{Wstęp}

Siłą napędową koreańskiej gospodarki są szkolnictwo i przedsiębiorczość. Od 1960 do 2017 r. PKB wzrósł niemal sześciokrotnie, PKB per capita (według parytetu siły nabywczej) w 2017 r. wynosił 38,3 tys. dol. Dla porównania w Polsce - 29 tys. dol. Do wzrostu popularności działań przedsiębiorczych w Republice Korei przyczynia się rząd, który wskazuje kierunek dalszego rozwoju. W ramach ogłoszonego w sierpniu 2017 r. planu pięcioletniego przygotowanego przez administrację obecnego prezydenta Republiki Korei, Mun Jae-ina, podjęto się promowania ekosystemu przedsiębiorczego, w tym rozwoju kreatywnych startupów i kształtowania innowacyjnych przedsiębiorców. Promowane są wszystkie próby podejmowania działań przedsiębiorczych. Bez względu na właściciela procesu przedsiębiorczego, skali działań czy zasięgu prowadzonej aktywności.

\section{Wybrane aspekty kultury koreańskiej}

Cechą charakterystyczną kultury koreańskiej jest nieustanne konkurowanie już na poziomie indywidualnym. Konkurują ze sobą rodzice, przykładowo o to, do jakiej szkoły zapisać dziecko, jaką wyprawkę szkolną zorganizować, konkurują ze sobą dzieci. Praca w zespole, pojęcie współpracy opartej na zaufaniu właściwie nie funkcjonują, z uwagi na społecznie akceptowalną postawę skoncentrowaną na wynikach indywidualnych, tj. nieustającej konkurencji. System ocen na poziomie akademickim podtrzymuje tę konwencję poprzez egzekwowanie od wykładowców oceny studentów w myśl rozkładu normalnego.

Wskaźnik samobójstw i wskaźnik spożycia alkoholu są na wysokim poziomie, co tłumaczy się niskim poziomem zadowolenia z życia, pomimo wysokich zarobków. I choć subiektywna satysfakcja z życia poprawiła się w ostatniej dekadzie, nadal jest poniżej średniej krajów OECD (2017b, s. 263). Opisując charakterystyczne cechy społeczeństwa, Koreańczycy te wskaźniki często przywołują razem. Jednak spożycie alkoholu najwyższe jest na Litwie, wyższe od Republiki Korei jest także w Polsce. Litwa zajmuje pierwsze miejsce, Polska - 12., a Korea - 23. (OECD, 2018a). Jeśli chodzi o wskaźnik samobójstw, to Koreańczycy zajmują drugą lokatę zaraz po Litwinach (OECD, 2018b). W 2015 r. na 100 tys. osób Koreańczycy popełnili 25,8 samobójstw. Dla porównania w Polsce wskaźnik ten wynosi 13,5.

W Republice Korei występuje także zjawisko dyskryminacji płciowej, choć ma być zwalczane, przykładowo regulacjami prawnymi, 
które mają determinować obecność kobiet w organach zarządczych przedsiębiorstw. W organizacjach powszechne jest zwalnianie kobiet, które urodziły dziecko. W innych przypadkach doradza się kobietom dobrowolną rezygnację z pracy np. przed 35. rokiem życia, ponieważ przyjmuje się, że po tym okresie chciałyby mieć one już dzieci. Stąd zakładanie przedsiębiorstw jest $\mathrm{z}$ jednej strony szansą na realizację pomysłów i wykorzystanie kompetencji, $z$ drugiej zapobiega bezrobociu, pozwala także na pracę $\mathrm{w}$ dowolnym czasie. Celem poprawy warunków pracy na etacie w 2018 r. zarządzono maksymalnie 52-godzinowy tydzień pracy, jednak w weekendy pozwala się na więcej przepracowanych godzin.

\section{Narzędzia rozwoju przedsiębiorczości}

Zmiany w otoczeniu gospodarczym znajdują swoje odzwierciedlenie także w strukturze instytucjonalnej. Agencję rządową stworzoną dla małych i średnich przedsiębiorstw (ang. Small and Medium Business Administration, SMBA), którą nadzorowało Ministerstwo Handlu, Przemysłu i Energii, odpowiadające przede wszystkim za regulowanie polityki gospodarczej, w 2017 r. zastąpiło Ministerstwo MSP i Start-upów. Przez 21 lat SMBA wspierała innowacje po stronie MSP jako katalizatora wzrostu gospodarki narodowej, dążąc przy tym do ich stabilnego rozwoju. Obecny rząd zamierza dalej wyzwalać potencjał przedsiębiorczy młodych ludzi.

Do narzędzi wspierających należą: programy dla młodzieży pomagające w wyborze ścieżki kariery i rozwoju ich aktywności przedsiębiorczej, inkubatory przedsiębiorczości przy uniwersytetach i innych instytucjach badawczych, szkolenia i kluby stratupowe, szkoły biznesu i programy dla start-upów uruchamiane w całym kraju (Sahay i Sharma 2008, s. 166-167). Przykładowym programem jest Youth Start-up Academy uruchomiony w 2011 r. dla potencjalnych przedsiębiorców poniżej 39. roku. Studenci nabywają wiedzę z zakresu budowania podmiotu gospodarczego, otrzymują częściowe finansowanie poniesionych kosztów związanych z jego rozwojem, szkoleni są przez specjalistów-praktyków biznesu, a także otrzymują narzędzia i przestrzeń do pracy. Kolejnym narzędziem jest współpraca rządowa z dużymi przedsiębiorstwami, czego efektem są projekty, które upowszechniają wiedzę z zakresu budowania sklepów internetowych czy promowania produktów, np. E-commerce Dream Project dużego portalu Naver. 
Koreańczycy, którzy nauczeni są konkurowania, mają okazję brać udział także w corocznym konkursie budowania przedsięwzięcia biznesowego - K-start-up Contest, w którym łącznie można wygrać pół miliona dolarów, zdobyć kontakty biznesowe i skupić na sobie uwagę mediów.

Inkubatory zapewniają usługi doradcze w zakresie funkcjonowania podmiotów gospodarczych. W grudniu 2017 r. zanotowano ponad 206 tys., które przetrwały pięć lat, natomiast ponad 520 tys. start-upów funkcjonowało na rynku przez rok, z czego 91,5 proc. miało założycieli indywidualnych, a 8,5 proc. pozostałych podmiotów założyły spółki. Struktura wykształcenia założycieli start-upów pokazuje, że najwięcej, niemal 38,3 proc., ukończyło licencjat, około 36,2 proc. szkołę średnią, a niecałe 11 proc. ma wykształcenie niższe niż średnie (Statista 2018). Przykładem inkubatora jest choćby Aspirin Incubation Center, które również zapewnia przestrzeń do pracy, pomaga w rozwiązywaniu problemów i promuje programy rozwoju. Największym inkubatorem jest Seoul Startup Hub. Do jego głównych działań należą: networking, badania rynku, program inkubacji, edukacja i konsulting (Seoul Startup Hub, 2017). Celem networkingu jest umożliwienie nawiązania stosunków między start-upami, inwestorami, akceleratorami, interesariuszami i ekspertami przykładowo od marketingu czy podatków. Badania obejmują analizy ekosystemu przedsiębiorczości, w tym wielkości podmiotów, analizy profilu uczestników ekosystemu, infrastruktury, trendów biznesowych i benchmarking, które mają przełożyć się na aktywne współtworzenie otoczenia prawno- politycznego. Program inkubacji polega na ćwiczeniu prezentacji sprzedażowych dla potencjalnych inwestorów. Edukacja obejmuje 75 godzin wykładów specjalizacyjnych ukierunkowanych na budowanie i rozwój podmiotów gospodarczych na poziomie podstawowym i od sześciu do dziewięciu godzin ćwiczeń praktycznych z marketingu, projektowania i finansów. Kurs globalny przeznaczony jest dla przedsiębiorców, którzy chcą działać na skalę międzynarodową, a ich celem jest nabycie kluczowych kompetencji, które mają im to umożliwić. Program oferuje także zajęcia w obszarze projektowania i rozwoju aplikacji internetowych oraz przemawiania. W ramach konsultacji można uzyskać porady od ekspertów z dziedziny prawa, zasobów ludzkich, technologii, marketingu, praw własności intelektualnej, start-upów czy zarządzania. 


\section{Edukacja na poziomie akademickim}

Agencja rządowa SMBA zapoczątkowała także działalność szkół przedsiębiorczości w strukturze uniwersytetów. Ministerstwo je wspiera, aby zapewnić edukację w zakresie przedsiębiorczości systemowo. Celem szkół jest z kolei rozwój ekspertów start-upów, którzy wykażą się elastycznością w działaniu, umożliwiającym adaptację do zmian w otoczeniu. Zaprojektowane kursy i wybrane metody kształcenia mają nauczyć studentów identyfikowania luki rynkowej i podejmowania ryzyka. Przykładowymi uniwersytetami, które uruchomiły szkoły przedsiębiorczości, są: Hoseo University (Graduate School of Global Entrepreneurship), Chung-Ang University (Graduate School of Industrial and Entrepreneurial Management), Kookmin University (Graduate School of Global Entrepreneurship), Handong Global University (Global Entrepreneurship and Information, Communication Technology). W Hoseo University szkoła ma przypisany profil ogólny, natomiast w Chung-Ang i Kookmin University została ona skategoryzowana jako program specjalny. W Chung-Ang University wykłady i studia przypadków osadzono w problematyce administracji wiedzą, dystrybucji, zmian klimatycznych, zarządzaniu przedsiębiorczym, konsultingu przedsiębiorczym i globalnej franczyzie. Edukacja przedsiębiorczości w Kookmin University przeznaczona jest dla osób pracujących, które chcą założyć biznes. Oferowane są dwuletnie kierunki, takie jak inkubacja, edukacja i venture, które uzupełnione są o obowiązkowy staż. Praktyki przedsiębiorcze i wiedza przekazywane są przez wykładowców akademickich, przedsiębiorców seryjnych, inwestorów kapitału podwyższonego ryzyka (ang. venture capital), aniołów biznesu, decydentów oraz regionalnych i krajowych liderów biznesu.

Soongsil University otworzył Zakład Przedsiębiorczości i Małego Biznesu w 1995 r., którego celem jest praktyczne uzupełnienie teoretycznych dyskusji. Tym samym prace tego zakładu koncentrują się na budowaniu szans rynkowych, tworzeniu nowych rynków, zróżnicowaniu produktów, akceleracji wzrostu podmiotów gospodarczych. Do najważniejszych przedmiotów należą: rachunkowość, statystyka, finanse przedsiębiorstw, przedsiębiorstwo społeczne, inwestycje podwyższonego ryzyka, rozwój przedmiotu działalności, wstęp, program i polityka dotycząca MSP, trening przedsiębiorczego start-upa, studia przypadku w marketingu, przedsiębiorczość globalna oraz praktyki przedsiębiorcze w sektorze usług. 
W Sookmyung Women's University w 2010 r. utworzono Zakład Zarządzania w ramach Szkoły Usług Globalnych (ang. School of Global Service), którego celem jest ukształtowanie liderów-założycieli podmiotów innowacyjnych i z wizją. Promowana jest innowacyjność oparta na kobiecej wrażliwości, emocjach, humanizmie i elastyczności wobec zmieniającego się otoczenia. Znajomość języków obcych traktuje się jako narzędzia poznania kultury, stąd przedmioty nauczane są w języku angielskim, co ma wspierać myślenie globalne, ale wymaga się także nauki japońskiego lub chińskiego, by lepiej zrozumieć rynek azjatycki. Wśród kompetencji wymienia się umiejętność planowania i wdrażania pomysłów na skalę globalną.

Handong Global University oferuje kierunek przedsiębiorczość globalna. Do kluczowych kompetencji absolwentów należą: postawa przedsiębiorcza, analiza problemowa rynku, planowanie projektowe, rozwój biznesu, rozwiązywanie problemów i rozwój przedmiotu działalności, a do podstawowych zagadnień tematycznych: budowa przedsiębiorstwa, badanie rynku, rachunkowość i inwestycje, marketing, prawo i etyka w biznesie.

Najstarszą, założoną w 1905 r. i jednocześnie najlepszą akredytowaną szkołą biznesu w Republice Korei jest Korea University Business School. Ceni się ją z uwagi na badania i edukację, ale i utożsamia z innowacyjnością. Charakteryzują ją silna sieć absolwentów z najwyższą notowaną liczbą dyrektorów generalnych i biegłych rewidentów księgowych. Szkoła otworzyła również Instytut Start-upów, który stanowi forum dyskusji i działań na rzecz innowacji, współpracy i dzielenia się zarówno wiedzą, jak i doświadczeniem. Jest centrum inkubacji przedsięwzięć biznesowych i dostarczania wiedzy. Do narzędzi promocji przedsiębiorczości należą konkurs dla start-upów, gdzie zwycięzcy mogą otrzymać finansowanie kosztów operacyjnych, sesje mentoringowe przykładowo w zakresie prawa, patentów czy marketingu, networking z inwestorami dostarczającymi kapitału wysokiego ryzyka i innymi przedsiębiorcami, przestrzeń do pracy indywidualnej i zespołowej, prowadzenie seminariów. W ramach oferowanego programu edukacyjnego serie wykładów na temat przedsiębiorczości i innowacji oraz treningi umiejętności prowadzą praktycy (KUBS 2014a). Na uniwersytecie dla studentów I stopnia utworzono Program Akademii Przedsiębiorczości (ang. Entrepreneurship Academy Program) ukierunkowany na ukształtowanie przedsiębiorców podejmujących działania stymulowane wy- 
zwaniami. Tematami podejmowanymi w procesie kształcenia są: technologia, społeczeństwo i kultura, a prowadzącymi są także wybrani dyrektorzy generalni podmiotów gospodarczych (KUBS 2014b).

Jeśli już utworzono opis kierunku w języku angielskim, to zaprezentowane w nim cele przyjęte przez wybrane uniwersytety rzadko kiedy się powtarzają. W badaniu przeprowadzonym przez Byun, Sung, Park i Choi wykazano, że do najważniejszych elementów w zakresie przekazywanej wiedzy o przedsiębiorczości i start-upach należą: szukanie szans rynkowych, opracowanie planów biznesowych i analizy wykonalności, budowanie biznesplanu, rachunkowość, finanse i marketing. Do pozostałych przedmiotów, które uważa się za istotne, można zaliczyć: kapitał podwyższonego ryzyka i przedsiębiorczość technologiczną, a także komercjalizację (Byun i in. 2018, s. 8). Dla studentów i absolwentów szkół przedsiębiorczości ważne są: sieć absolwentów, partnerstwo z instytucjami zewnętrznymi, mentoring i szkolenia zarówno w trakcie studiów, jak i po ich zakończeniu (Byun i in. 2018, s. 10). Docenia się także wizyty praktyków na zajęciach, a także prowadzenie ich przez doświadczonych instruktorów i nauczycieli, którzy zarządzają start-upem. Analiza130 ankiet studentów kierunku projektowanie biżuterii w badaniu Chang i Choi (2018, s. 2939) potwierdziła, że dla rozpoczęcia biznesu najważniejsze przedmioty w edukacji przedsiębiorczości to: marketing, finansowanie oraz networking, tj. nawiązywanie relacji, a także projektowanie oraz zarządzanie wiedzą. Potwierdzono również, że edukacja przedsiębiorczości pozytywnie wpływa przede wszystkim na intencje przedsiębiorcze, następnie na wzrost innowacyjności, wdrażanie kolejnych pomysłów, wrażliwość na ryzyko oraz rozwój sieci społecznej. Studenci podejmujący kurs przedsiębiorczości odnotowują wyższy poziom intencji przedsiębiorczych i wiary we własne możliwości - wyższy także od poziomu amerykańskich studentów, co prawdopodobnie tłumaczą kultura konkurowania i potrzeba osiągnięć (Lee i in. 2005 , s. 38). Otoczenie społeczne i ekonomiczne pozytywnie wzmacniają poziom motywacji oraz pewności siebie, a intencje budowania podmiotów są także remedium na ograniczone możliwości otrzymania miejsca pracy (Lee i in. 2006, s. 360).

Odpowiedzi udzielone podczas przeprowadzonych wywiadów jakościowych, które odbyły się w lipcu i listopadzie 2018 r. w Republice Korei, potwierdzają, że studenci, którzy nie kończą kierunku przedsiębiorczość, nie zdobywają wiedzy praktycznej, jak zbudować biznes. Absolwenci 
studiów innych kierunków, którzy uczestniczyli w badaniu, nie mieli możliwości wybrania przedmiotów dodatkowych, podczas których taką wiedzę można by nabyć. Wywiady częściowo standaryzowane niestrukturalizowane, które trwały od 70 do 90 minut każdy, przeprowadzono $z$ dwoma mężczyznami i trzema kobietami. Najmłodszy rozmówca miał 36 lat. Trzech interlokutorów, każdy indywidualnie, prowadzi działalność krótkoterminowego wynajmu mieszkań. Połączyła ich jednak pasja do sztuki. Wspólnie uruchomili inicjatywę biznesową ArtTrip, która polega na organizowaniu projektów artystycznych i wystaw w przestrzeniach mieszkalnych. Jeden z pozostałych interlokutorów jest dyrektorem generalnym i założycielem MegaGen - podmiotu produkującego implanty, których dystrybucja odbywa się w ponad 60 krajach na świecie. Wywiad przeprowadzono także z dyrektorką jednego z działów MegaGen. Interlokutorzy przyznali, że kierunek studiów determinuje plan zajęć, a przekazywana wiedza często jest niewystarczająca z uwagi na brak aktualizacji treści kursu. Nie uczy się krytycznej analizy sytuacji, za mało, jeśli w ogóle, jest ćwiczeń praktycznych, nie wyzwala się także w studentach zachowań zespołowych, co wzmacniane jest choćby przez system oceniania studentów, który promuje konkurowanie. Przedsiębiorcy, absolwenci uniwersytetów, którzy założyli działalność gospodarczą, przyznają, że gros absolwentów kończy studia, idzie do pracy, gdzie zdobywa wiedzę, umiejętności czy buduje bazę klientów, po czym rezygnuje z miejsca pracy celem założenia działalności gospodarczej o podobnym profilu. Stąd, jak sami podkreślają, trudno znaleźć właścicieli przedsiębiorstw młodszych niż 30 lat. W raporcie dla OECD (Green 2013, s. 1) zaznaczono, że termin "młodzi” w kontekście bezrobocia odnosi się do ludzi poniżej 35. roku życia.

\section{Zakończenie}

Uniwersytety w Republice Korei mają kształcić wykwalifikowanych pracowników przygotowanych do podjęcia pracy, tworzyć wiedzę w drodze badań celem podniesienia poziomu inteligencji ludzi i rozwoju innowacji, które zmienią status quo na rynku, oraz przyczynić się do wzrostu poziomu opieki społecznej poprzez rozpowszechnianie wiedzy i innowacji w społeczeństwie. Kolejną rolą uniwersytetów stało się promowanie przedsiębiorczości i przedsięwzięć wysokich technologii. Oczekuje się z jednej strony wdrożenia i uruchomienia programów edukacji przedsiębiorczości, z drugiej komercjalizacji wiedzy i nowych technologii 
chociażby poprzez utworzenie podmiotów typu spin-off czy uzyskanie licencji (Bae i Park 2011, s. 114-115). Mimo to brakuje rozwiązań systemowych na poziomie edukacji. Każdy program przedsiębiorczości tworzony jest w odosobnieniu. Nie ma wskazanych kompetencji, które mają nabyć absolwenci. Problemem jest także kopiowanie rozwiązań biznesowych. Rozwój narzędzi cyfrowych i platform internetowych stworzył nowe szanse rynkowe dla przedsiębiorców, w szczególności prowadzących jednoosobową działalność gospodarczą. Eksport promowany jako skuteczne narzędzie wzrostu gospodarczego ugruntował w studentach intencje do zakładania działalności o zasięgu ponadnarodowym (Lee i in. 2006, s. 363), a narzędzia internetowe pozwalają im na nawiązanie relacji biznesowych na skalę globalną. MSP zajmują czołową pozycję w handlu międzynarodowym przy wykorzystaniu narzędzi cyfrowych (OECD 2017a, s. 30). Kolejnym krokiem w polityce wzrostu jest podniesienie innowacyjności i kreatywności przedsiębiorców. 


\section{Bibliografia}

$\rightarrow 100$ Policy Tasks Five-year Plan of the Moon Jae-in Administration, August 17, 2017, Korean Culture and Information Service.

$\rightarrow$ Bae, Z., Park, S. (2011), University Technology Commercialization and Academic Entrepreneurship in Korea: The KAIST Experience [w:] P.K. Wong (red.), Academic Entrepreneurship in Asia: The Role and Impact of Universities in National Innovation Systems, Cheltenham: Edward Elgar Publishing, s. 108-134.

$\rightarrow$ Byun, C.G., Sung, C., Park, J., Choi, D. (2018), A Study on the Effectiveness of Entrepreneurship Education Programs in Higher Education Institutions: A Case Study of Korean Graduate Programs, „Journal of Open Innovation: Technology, Market, and Complexity", 4 (3), s. 26.

$\rightarrow$ Chang, C.H., Choi, S.H. (2018), A Study on Entrepreneurship Education and Entrepreneurial Intentions of Jewelry Design Majors in South Korea, "Journal of Engineering and Applied Sciences", 13, s. 2935-2940.

$\rightarrow$ Lee, S.M., Chang, D., Lim, S.B. (2005), Impact of Entrepreneurship Education: A Comparative Study of the U.S. and Korea, "International Entrepreneurship Management Journal", 1, s. 27-43.

$\rightarrow$ Lee, S.M., Lim, S.B., Pathak, R.D., Chang, D., Li, W. (2006), Influences on students attitudes toward entrepreneurship: A multi-country study, „Entrepreneurship Management", 2, s. 351-366.

$\rightarrow$ OECD (2017a), Entrepreneurship at a Glance 2017, Paris: OECD Publishing.

$\rightarrow$ OECD (2017b), How's Life? 2017: Measuring Well-being, Paris: OECD Publishing.

$\rightarrow$ Sahay, A., Sharma, V. (2008), Entrepreneurship and New Venture Creation, New Delhi: Excel Books. 


\section{Netografia}

$\rightarrow$ Green, F. (2013), Youth Entrepreneurship, www.oecd.org/cfe/leed/youth_bp_finalt.pdf (dostęp: 30.11.2018).

$\rightarrow$ KUBS (2014a), Startup Station, biz1.korea.ac.kr/en/node/43011 (dostęp: 26.11.2018).

$\rightarrow$ KUBS (2014b), [Undergraduate] Entrepreneurship Academy Program-based Scholarship, biz1.korea.ac.kr/en/undergraduate/notice/undergraduate-entrepreneurship-academy-program-based-scholarship (dostęp: 26.11.2018).

$\rightarrow$ OECD (2018a), Alcoholconsumption, data.oecd.org/healthrisk/alcohol-consumption.htm (dostęp: 22.11.2018).

$\rightarrow$ OECD (2018b), Suiciderates, data.oecd.org/healthstat/suicide-rates.htm (dostęp: 22.11.2018).

$\rightarrow$ Seoul Startup Hub (2017), Program, seoulstartuphub.com/eng/sub/program/ network.jsp (dostęp: 26.11.2018).

$\rightarrow$ SMBA, www.koisra.co.kr/en/partners/governmental.html (dostęp: 30.11.2018).

$\rightarrow$ Statista (2018), The most important statistics, www.statista.com/statistics/717996/south-korea-number-of-start-ups-by-business-age (dostęp: 26.11.2018). 


\section{Rola przedsiębiorczości imigrantów w rozwijaniu postaw przedsiębiorczych kraju przyjmującego}

Agnieszka Brzozowska

Coraz większe wyzwania związane z migracjami sprawiają, że kraje przyjmujące stają przed koniecznością tworzenia takich rozwiązań, które możliwie najbardziej efektywnie pozwolą imigrantom zaadaptować się na rynku pracy. Jak pokazują badania, przedsiębiorczość imigrantów może być właśnie takim rozwiązaniem, ma ona bowiem - oprócz pozytywnego wpływu na integrację imigrantów - korzystne oddziaływanie na przedsiębiorczość autochtonów. W artykule skupiono się na znaczeniu przedsiębiorczości imigrantów w rozwoju przedsiębiorczości społeczności kraju przyjmującego.

\section{Słowa kluczowe:}

przedsiębiorczość imigrantów

integracja imigrantów

kompetencje przedsiębiorcze imigrantów 


\section{The role of immigrant entrepreneurship in the development of entrepreneurship in the host countries}

Agnieszka Brzozowska

In the face of increasing challenges related to migration, it is important for the host countries to build solutions that will make immigrants adapt in the labor market in the most effective way. As research shows, immigrant entrepreneurship could be one of the solutions. In addition to the positive impact on the integration of immigrants, it turns out that it often has a positive impact on entrepreneurship among native people. The text focuses on the importance of immigrant entrepreneurship in the development of community entrepreneurship in the host country.

\section{Keywords:}

immigrant entrepreneurship

integration of immigrants

entrepreneurial skills of immigrants 


\section{Wprowadzenie}

Zjawisko migracji i przedsiębiorczości imigrantów jest bardzo złożone. Analiza literatury przedmiotu z krajów z długą historią imigracyjną pozwala spojrzeć na możliwe kierunki prowadzenia polityki imigracyjnej w państwach, które dopiero stają się krajami docelowymi dla imigrantów, i jej możliwe konsekwencje dla rozwoju przedsiębiorczości. Dzięki temu, że badania dotyczące przedsiębiorczości imigrantów od wielu lat są prowadzone równolegle w różnych krajach, można zebrać ciekawy materiał, ukazujący między innymi, w jaki sposób przedsiębiorcze inicjatywy imigrantów wpływają pozytywnie na ogólny dobrobyt krajów przyjmujących i na samo zjawisko przedsiębiorczości (Kushnirovich 2015). Najdłuższą tradycję badawczą w tym obszarze mają przede wszystkim kraje będące najczęstszymi celami migracji ludności, czyli Stany Zjednoczone, Kanada, Australia oraz państwa Europy Zachodniej (Fairlie 2008, Portes, Borocz 1989, Saxenian 2002b). W ostatnich latach również w Polsce zainteresowanie tematem przedsiębiorczości migrantów przybrało na sile, między innymi z powodu zwiększenia się skali imigracji i zauważalnych inicjatyw przedsiębiorczych cudzoziemców (Andrejuk 2016, Brzozowski 2017, Glinka, Brzozowska 2015).

Wiele badań wskazuje na to, że porównując osoby urodzone w kraju zamieszkania z osobami, które urodziły się za granicą, można zauważyć, że wśród tych drugich odsetek osób prowadzących swoje firmy jest większy (Borjas 1986, Lofstrom 2002, Light, Rosenstein 1995). Robert W. Fairlie (2008) zauważa, że w Stanach Zjednoczonych imigranci chętniej zakładają firmy niż autochtoni. Może to wynikać $z$ ich specyficznego podejścia do ryzyka i samej przedsiębiorczości, a także wyposażenia w takie kompetencje, które pozwalają podejmować odważne i niestandardowe decyzje (Berger 1991). Skoro imigranci byli w stanie zdecydować o emigracji, to założenie własnej firmy nie stanowi dla nich większego wyzwania. Evgueni Vinogradov i Eva Jenny Benedikte Jørgensen (2016) zauważają również, że imigranci częściej dostrzegają okazje związane z prowadzeniem biznesu na skalę międzynarodową, podejmując kooperację z partnerami zagranicznymi. Ponadto w Stanach Zjednoczonych imigranci są bardziej zauważani w branżach wysokich technologii (Hart, Acs 2011) i biotechnologii (Stephan, Levin 2001), gdyż stanowią dużo większy odsetek wśród właścicieli tego rodzaju firm. 
Nie zawsze jednak własna firma jest dobrowolnym wyborem imigrantów. Zdarza się bowiem, że imigranci wybierają możliwość samozatrudnienia z braku możliwości znalezienia pracy etatowej (Zhou 2004), między innymi z powodu bariery językowej, efektu "szklanego sufitu", braku kwalifikacji uznawanych w kraju przyjmującym. Nierzadko przyczyną niemożności znalezienia pracy są różne przeszkody instytucjonalne w polityce państwa przyjmującego, które dyskryminują imigrantów jako potencjalnych pracowników (Kloosterman 2010). Polityka ta opiera się na bardzo krótkowzrocznym myśleniu ze strony państwa, które nie docenia potencjału cechującego imigrantów prowadzących swoje firmy. Międzynarodowa wiedza, kontakty z krajem pochodzenia, znajomość innej kultury czy doświadczenie międzynarodowe imigrantów można byłoby wykorzystywać w celu sprzedaży produktów i usług w innych krajach, a także zwiększenia znaczenia kraju przyjmującego w handlu międzynarodowym (Oviatt, McDougall 1994). Są jednak państwa, w których politycy zauważają znaczenie imigrantów w gospodarce, oferują im specjalne wizy i ułatwienia, zachęcając tym samym obcokrajowców do prowadzenia swoich firm właśnie $w$ tym kraju (Fairlie, Lofstrom 2015).

Ogólnie przedsiębiorczość imigrantów jest uznawana za realne rozwiązanie problemu braku pracy dla imigrantów, pozwala im uzyskiwać satysfakcjonujące wynagrodzenie, sprzyja rozwojowi gospodarczemu kraju przyjmującego i jest ważnym czynnikiem integracji imigrantów (Heilbrunn, Kushnirovich 2008, Riva, Lucchini 2015).

\section{Wpływ przedsiębiorców imigrantów na rynek kraju przyjmującego}

Problem migrantów jest w społeczeństwach krajów przyjmujących często traktowany z rezerwą, zdarza się jednak, że i z dużą niechęcią. Tymczasem wiele wyników badań świadczy o tym, że przedsiębiorczość imigrantów wpływa pozytywnie na rozwój gospodarczy kraju, w którym jest ona prowadzona, i buduje regionalne przewagi konkurencyjne oraz sprzyja innowacjom (Cummings 1980, Hunt $i$ in. 2010). Na przykład w Stanach Zjednoczonych imigranci prowadzący firmy w branżach wymagających wysokich kwalifikacji w Dolinie Krzemowej odgrywają bardzo ważną rolę w gospodarce, między innymi pobudzając innowacje (Saxenian 2002a). 
Pozytywny wpływ firm zakładanych przez imigrantów na rynek pracy kraju przyjmującego może przejawiać się w trzech formach:

$\rightarrow$ tworzenie możliwości zatrudnienia dla osób, które nie są dostrzegane przez główne rynki pracy,

$\rightarrow$ zmniejszanie konkurencji z rodzimymi pracownikami,

$\rightarrow$ rozwijanie tych modeli przedsiębiorczości, które zapewnią imigrantom możliwość uzyskiwania większych zarobków (Zhou 2004).

Zoltan J. Acs i Catherine Armington (2004), podejmując analizy tekstów Paula M. Romera (1990) i Paula Krugmana (1991), stworzyli model, w którym tłumaczą, w jaki sposób wzrost zatrudnienia w regionie jest powiązany z trzema kluczowymi czynnikami: przedsiębiorczością, skutkami aglomeracji i kapitałem ludzkim. Ich analiza empiryczna wykazała, że nowe firmy są ważniejszymi motorami wzrostu ekonomicznego niż istniejące firmy w regionie, a rozpowszechnianie wiedzy jest kluczowym składnikiem pobudzającym lokalną przedsiębiorczość.

Warto również wspomnieć o roli kulturowych cech i uwarunkowań imigrantów, które pozytywnie kształtują kapitał społeczny w kraju przyjmującym (Chand, Ghorbani 2011, Peredo, Chrisman 2006). Bo Carlsson i Statton Jacobson (1997) sugerują, że doświadczenie przez imigrantów funkcjonowania na płaszczyźnie dwóch kultur może zwiększać „przestrzeń poszukiwań" okazji do podejmowania przedsięwzięć biznesowych. Imigranci mogą na przykład dostrzec potencjalne rynki lub relacje $w$ łańcuchu dostaw $w$ ich kraju ojczystym lub w kraju przyjmującym, które nie są widoczne dla tych, którym brakuje takiego tła. Powiązania z ojczyzną zwiększają natężenie współpracy z krajem przyjmującym, co zwiększa produktywność (Peri 2012).

W Stanach Zjednoczonych, które mają długą i bogatą historię migracji, sami przedsiębiorcy zwracają uwagę na zalety funkcjonowania imigrantów przedsiębiorców w społeczeństwie kraju przyjmującego i walczą o bardziej otwarte podejście do tej kwestii, szczególnie dla branż związanych z high-tech (Gates 2008, Herman, Smith 2009). Wyniki badań prowadzonych na firmach z sektora high-tech w Stanach Zjednoczonych wskazują, że przedsiębiorstwa prowadzone przez imigrantów nie różnią się pod względem wielkości czy efektywności działania od firm prowadzonych przez autochtonów, ale za to częściej działają na arenie międzynarodowej, budując szczególne relacje z przedsiębiorstwami z kraju pochodzenia, co zwiększa umiędzynarodowienie firm, pole ich 
działania i transfer wiedzy (Hart, Acs 2011). Jak bowiem pokazują badania, jednym z czynników sprzyjających umiędzynarodowieniu firm są osobiste orientacje ich założycieli (Wach 2015), duże znaczenie będzie więc miała osoba imigranta - założyciela firmy. Jeśli imigranci swobodnie komunikują się w języku kraju przyjmującego, to szybciej budują kontakty między grupą etniczną, z jakiej pochodzą, a społeczeństwem kraju, w którym żyją. Pozwala to wykorzystać te połączenia do zwiększenia kreatywności działania i angażowania wysoko wykwalifikowanych pracowników niezależnie od kraju pochodzenia. Obecność wysoko wykwalifikowanych imigrantów w Stanach Zjednoczonych powoduje wzrost poziomu innowacyjności technologicznej (Hunt, Gauthier-Loiselle 2010) oraz liczby rejestrowanych przez nich patentów (Wadhwa i in. 2007). Typ przedsiębiorczości, który polega na prowadzeniu działalności biznesowej w kraju przyjmującym i w kraju rodzinnym, jest nazywany przedsiębiorczością transnarodową (Vertovec 2004). Unikalnym zasobem takich przedsiębiorców jest rozumienie sposobu funkcjonowania klientów kraju ojczystego i kraju przyjmującego (Brzozowski, Cucculelli, Surdej 2014), co pozwala rozwinąć przedsiębiorczość międzynarodową.

Podsumowując, przedsiębiorczość wydaje się bardzo dobrym sposobem integracji społeczno-ekonomicznej imigrantów (Constant, Zimmermann 2004). Może to potwierdzić choćby przedsiębiorczość drugiego pokolenia imigrantów, którzy dzięki edukacji w kraju przyjmującym, rozległej siatce kontaktów, także z autochtonami, braku barier językowych i znajomości kultury kraju przyjmującego, aktywnie uczestniczą w rynku głównym (Jones i in. 2000, Rusinovic 2008).

Zdarza się jednak także, że prowadzący działalność gospodarczą imigranci mogą wypierać rodzimych przedsiębiorców z rynku, choć dotyczy to głównie firm, które nie rokują dużych przychodów (Fairlie, Meyer 2003), prawdopodobnie zatem i tak by nie przetrwały. Warto podkreślić, że analizy wskazują raczej, że wraz z migracjami z czasem zwiększa się ogólny poziom samozatrudnienia w kraju przyjmującym (Antecol, Schuetze 2007) i innowacyjność (Cummings 1980). Może to świadczyć, że w ogólnej perspektywie przedsiębiorczość migrantów mobilizuje do tworzenia firm o większym potencjale.

\section{Kultura przedsiębiorcza}

Kluczową rolę w rozwijaniu przedsiębiorczości należy przypisać osobom, które swoją postawą inicjują aktywność przedsiębiorczą. Duch przed- 
siębiorczości jest kształtowany dzięki kulturze przedsiębiorczej całej społeczności, którą tworzą jednostki. Jeśli indywidualni członkowie społeczności wspierają postawy przedsiębiorcze i same się charakteryzują takim podejściem, to innym łatwiej się zainspirować takim sposobem funkcjonowania. Imigranci przedsiębiorcy dokładają swoją cegiełkę do budowania postaw przedsiębiorczych w kraju przyjmującym. Współistnienie grup przedsiębiorczych mobilizuje i motywuje innych do rozwijania aktywności przedsiębiorczej.

Ponadto kultura - obejmująca wartości, przekonania czy styl życia - jest transferowana przede wszystkim w obrębie podstawowej komórki społecznej, jaką jest rodzina (Gray 1998). Tradycja prowadzenia własnej firmy jest mocno zakorzeniona w rodzinie (Hout, Rosen 2000). Oznacza to, że prowadzący firmy imigranci będą przekazywali swoim dzieciom postawę przedsiębiorczą, zaszczepiając kolejnym pokoleniom iskrę przedsiębiorczości. Nieprzypadkowo Stany Zjednoczone, kraj imigrantów, są uważane za miejsce, w którym szczególnie mocno można odczuć kulturę przedsiębiorczości (Galambos 2018). Proces ten trwał jednak wiele lat, a dziś możemy obserwować jego rezultaty, między innymi patrząc na szeroko opisywaną Dolinę Krzemową. Ponadto imigranci, którzy zakładają swoje firmy, są przykładem twórczej destrukcji (Schumpeter 1950), która sprawia, że w społeczeństwie są uwalniane pokłady kreatywności i przedsiębiorczości. Są ruchem, który zmienia obecny stan równowagi i mobilizuje do zmian, poszukiwania nowych rozwiązań.

\section{Zakończenie}

Biorąc pod uwagę, że imigranci są grupą, która najczęściej decyduje się na zakładanie własnych firm, jednocześnie zaś jej przedstawiciele tworzą rozwiniętą siatkę kontaktów, można założyć, że przedsiębiorcy ci powinni być jednym z ważniejszych źródeł pobudzenia wzrostu gospodarczego kraju przyjmującego. Na pewno przedsiębiorczość imigrantów zmienia dynamikę funkcjonowania firm w kraju przyjmującym, co sprawia, że wszyscy przedsiębiorcy muszą szukać nowych form zaistnienia na rynku, to z kolei pozytywnie może wpływać na rozwój kreatywności i kompetencji przedsiębiorczych. Przedsiębiorcy pochodzący z innego kraju łączą różne kultury i sieci społeczne, sprawiając, że społeczeństwo przyjmujące staje się zróżnicowane. Korzyści ekonomiczne wynikające z różnorodności kulturowej mogą być rozmaite, 
między innymi wzbogacenie bazy społeczno-ekonomicznej, stworzenie zróżnicowanej podaży talentów na rynku pracy lub zwiększenie możliwości kreatywnych społeczeństwa (Jacobs 1961, Floryda 2002). Ponadto potencjał $w$ umiędzynarodowieniu, jakim odznaczają się imigranci, może pomóc w przezwyciężaniu obecnych problemów ekonomicznych (Zioło 2006). Migranci, wykazując specyficzne podejście do przedsiębiorczości i ryzyka z tym związanego, mogą pobudzać ogólnego ducha przedsiębiorczości w społeczeństwie, w którym funkcjonują. Przy dobrej integracji w kraju przyjmującym można liczyć na kooperację z autochtonami, co również korzystnie będzie oddziaływać na ogólny rozwój przedsiębiorczości. 


\section{Bibliografia}

$\rightarrow$ Acs, Z., Armington, C. (2004), The impact of geographic differences in human capital on service firm formation rates, "Journal of Urban Economics", 56, s. 244-278.

$\rightarrow$ Andrjeuk, K. (2016), Vietnamese in Poland: How does ethnicity affect immigrant entrepreneurship? , „Asian and Pacific Migration Journal”, 25 (4), s. 379-400.

$\rightarrow$ Antecol, H., Schuetze, H.J. (2007), Immigration, Entrepreneurship and the Venture Start-Up Process [w:] S.C. Parker, Z.J. Acs, D.R. Audretsch (red.), International Handbook Series on Entrepreneurship, t. 2, Boston: Kluwer Academic Publishers.

$\rightarrow$ Berger, B. (1991), The Culture of Modern Entrepreneurship [w:] B. Berger (red.), The Culture of Entrepreneurship, San Francisco, CA, s. 13-32.

$\rightarrow$ Borjas, G. (1986), The Self-Employment Experience of Immigrants. „Journal of Human Resources", 21, s. 487-506.

$\rightarrow$ Brzozowski, J. (2017), Immigrant Entrepreneurship and Economic Adaptation: A Critical Analysis, "Entrepreneurial Business and Economics Review", 5 (2), s. 159-176.

$\rightarrow$ Brzozowski, J., Cucculelli, M., Surdej, A. (2014), Transnational ties and performance of immigrant entrepreneurs: The role of home-country conditions, "Entrepreneurship \& Regional Development", 26 (7-8), s. 546-573.

$\rightarrow$ Carlsson, B., Jacobson, S. (1997), Diversity creation and technological systems: A technology policy perspective [w:] C. Edquist (red.), Systems of innovation, London: Pinter, s. 266-294.

$\rightarrow$ Chand, M., Ghorbani, M. (2011), National culture, networks and ethnic entrepreneurship: A comparison of the Indian and Chinese immigrants in the US, "International Business Review", 20, s. 593-606.

$\rightarrow$ Constant, E., Zimmermann, K.F. (2004), The Making of Entrepreneurs in Germany: Are Native Men and Immigrants Alike?, „IZADiscussion Paper Series”, 1440, Bonn: IZA. 
$\rightarrow$ Cummings, S. (1980), Self-Help in Urban America: Patterns of Minority Business Enterprise. New York: Kenikart Press.

$\rightarrow$ Fairlie, R.W. (2008), Estimating the contribution of immigrant business owners to the U.S. economy, "SBA Office of Advocacy Research Summary", 334, Washington, D.C.: SBA.

$\rightarrow$ Florida, R. (2002), The rise of the creative class. New York, NY: Basic Books.

$\rightarrow$ Galambos, L. (2018), The Entrepreneurial Culture and the Mysteries of Economic Development, "Essays in Economic and Business History", 36 (1), s. 290-320.

$\rightarrow$ Gates, B. (2008), Testimony before the U.S. House of Representatives, Committee on Science and Technology, www.microsoft.com/presspass/exec/billg/ speeches/2008/congress.mspx, (dostęp: 11.03.2019).

$\rightarrow$ Glinka, B., Brzozowska, A. (2015), Immigrant Entrepreneurs: in Search of Identity, "Entrepreneurial Business and Economics Review”, 3 (4), s. 51-76.

$\rightarrow$ Fairlie, R.W. (2008), Estimating the Contribution of Immigrant Business Owners to the U.S. Economy, Washington, D.C.: U.S. Small Business Administration, Office of Advocacy.

$\rightarrow$ Fairlie, R.W., Lofstrom, M. (2015), Immigration and Entrepreneurship [w:] B. Chiswick, P. Miller (red.), Handbook on the Economics of International Immigration, Amsterdam: Elsevier, s. 877-911.

$\rightarrow$ Fairlie, R.W., Meyer, B.D. (2003), The effect of immigration on native self-employment, "Journal of Labor Economics”, 21 (3), s. 619-650.

$\rightarrow$ Gray, C. (1998), Enterprise \& Culture, London: Routledge.

$\rightarrow$ Hart, D., Acs, Z. (2011), High-Tech Immigrant Entrepreneurship in the United States, „Economic Development Quartely", 25 (2), s. 116-129.

$\rightarrow$ Heilbrunn, S., Kushnirovich, N. (2008), Impact of ethnicity on financing of immigrant businesses, „International Journal of Business and Globalization”, 2 (2), s. 146-159.

$\rightarrow$ Herman, R.T., Smith, R.L. (2009), Immigrant, Hoboken, NJ: Wiley.

$\rightarrow$ Hout, M., Rosen H.S. (2000), Self-Employment, Family Background, and Race, „Journal of Human Resources”, 35 (4), s. 670-692.

$\rightarrow$ Hunt, J., Gauthier-Loiselle M. (2010), How Much Does Immigration Boost Innovation?, „American Economic Journal: Macroeconomics”, 2 (2), s. 31-56.

$\rightarrow$ Jones, T., Barrett, G., McEvoy, D., Rath, J. (2000), Market potential as a decisive influence on the performances of ethnic minority business [w:] J. Rath (red.), Immigrant Businesses: The Economic, Political and Social Environment, London: Macmillan, s. 37-53. 
$\rightarrow$ Kloosterman, R. (2010), Matching Opportunities with Resources: A Framework for Analyzing (migrant) Entrepreneurship from a Mixed Embeddedness Perspective, „Entrepreneurship and Regional Development", 22 (1), s. 25-45.

$\rightarrow$ Krugman, P. (1991), Increasing returns and economic geography, "Journal of Political Economy", 99, s. 483-499.

$\rightarrow$ Kushnirovich, N. (2015), Economic Integration of Immigrant Entrepreneurs, "Entrepreneurial Business and Economics Review", 3 (3), s. 9-27.

$\rightarrow$ Ley, D. (2006), Explaining variations in business performance among immigrant entrepreneurs in Canada, „Journal of Ethnic \& Migration Studies”, 32 (5), s. 743-764.

$\rightarrow$ Light, I.H., Rosenstein, C.N. (1995), Race, ethnicity, and entrepreneurship in urban America. New York, NY: Aldine de Gruyter.

$\rightarrow$ Lofstrom, M. (2002), Labor Market Assimilation and the Self Employment Decision of Immigrant Entrepreneurs, „Journal of Population Economics”, 15 (1), s. 83-114.

$\rightarrow$ Ndofor, H.A., Priem, R.L. (2011), Immigrant entrepreneurs, the ethnic enclave strategy, and venture performance, „Journal of Management", 37, s. 790-818.

$\rightarrow$ Oviatt, B., McDougall, P. (1994), Toward a theory of international new ventures, „Journal of International Business Studies”, 25 (1), s. 45-64.

$\rightarrow$ Peredo, A., Chrisman, J. (2006), Toward a theory of community-based enterprise, "Academy of Management Review", 31, s. 309-328.

$\rightarrow$ Peri, G. (2012), The Effect of Immigration on Productivity: Evidence from U.S. States, "Review of Economics and Statistics”, 94, s. 348-358.

$\rightarrow$ Portes, A., Borocz, J. (1989), Contemporary immigration: Theoretical perspectives on its determinants and modes of incorporation, „International Migration Review", 23, s. 606-630.

$\rightarrow$ Riva, E., Lucchini, M. (2015), The Effect of the Country of Birth of the Owner on Business Survival. Evidence from Milan Metropolitan Area, Italy, "Journal of Ethnic and Migration Studies", 41 (11), s. 1794-1814.

$\rightarrow$ Romer, P. (1990), Endogenous technological change, „Journal of Political Economy", 98, s. 71-102.

$\rightarrow$ Rusinovic, K. (2008), Moving between markets? Immigrant entrepreneurs in different markets, "International Journal of Entrepreneurial Behaviour \& Research", 14 (6), s. 440-454.

$\rightarrow$ Saxenian, A. (2002a), Silicon valley's new immigrant highgrowth entrepreneurs, "Economic Development Quarterly", 16, s. 20-31.

$\rightarrow$ Saxenian, A. (2002b), Brain circulation: How high-skill immigration makes everyone better off, „The Brooking Review”, 20, s. 28-31. 
$\rightarrow$ Schumpeter, J.A. (1950), Capitalism, Socialism and Democracy, New York: Harper \& Brothers Publishing.

$\rightarrow$ Stephan, P.E., Levin S.G. (2001), Exceptional contributions to US science by the foreign-born and foreign-educated, „Population Research and Policy Review", 20 (1-2), s. 59-79.

$\rightarrow$ Vertovec, S. (2004), Migrant transnationalism and modes of transformation, "International Migration Review", 38 (3), s. 970-1001.

$\rightarrow$ Vinogradov, E., Jørgensen, E.J.B. (2016), Differences in international opportunity identification between native and immigrant entrepreneurs, "Journal of International Entrepreneurship", 15 (2), s. 207-228.

$\rightarrow$ Wach, K. (2015), Entrepreneurial Orientation and Business Internationalisation Process: The Theoretical Foundations of International Entrepreneurship, „Entrepreneurial Business and Economics Review", 3 (2), s. 9-24.

$\rightarrow$ Wadhwa, V., Saxenian, A.L., Rissing, B.A., Gereffi, G. (2007), Education, Entrepreneurship and Immigration: America's New Immigrant Entrepreneurs, cz. 2, Duke University, Berkley and Ewing Marion Kauffman Foundation.

$\rightarrow$ Zhou, M. (2004), Revisiting ethnic entrepreneurship: Convergencies, controversies, and conceptual advancements, „International Migration Review”, 38 (3), s. 1040-1074.

$\rightarrow$ Zioło, Z. (2006), Rola przedsiębiorczości w podnoszeniu konkurencyjności społeczeństwa i gospodarki, „Przedsiębiorczość - Edukacja”, 2, s. 10-17. 


\section{Autorzy}

Monika Borgiasz-Stepaniuk

Uniwersytet Pedagogiczny im. Komisji

Edukacji Narodowej w Krakowie

\section{Paweł Brzegowy}

Uniwersytet Pedagogiczny im. Komisji

Edukacji Narodowej w Krakowie

\section{Agnieszka Brzozowska}

Uniwersytet Warszawski

\section{Sławomir Dorocki}

Uniwersytet Pedagogiczny im. Komisji

Edukacji Narodowej w Krakowie

\section{Magdalena Górowska-Fells}

Fundacja Rozwoju Systemu Edukacji,

Warszawa

\section{Mateusz Jeżowski}

Fundacja Rozwoju Systemu Edukacji, Warszawa

\section{Zygmunt Kawecki}

LXIV Liceum Ogólnokształcące im.

Stanisława Ignacego Witkiewicza

w Warszawie

XVI Liceum Ogólnokształcące im.

Stefanii Sempołowskiej w Warszawie

Stowarzyszenie Nauczycieli

Przedsiębiorczości i Edukacji

Ekonomicznej, Warszawa

\section{Wioletta Kilar}

Uniwersytet Pedagogiczny im. Komisji

Edukacji Narodowej w Krakowie

\section{Piotr Komraus}

Akademia WSB w Dąbrowie Górniczej

\section{Piotr Kopyciński}

Uniwersytet Ekonomiczny w Krakowie

\section{Wojciech Lasota}

Fundacja Korczakowska, Warszawa 
Julita Majczyk

Uniwersytet Warszawski

\section{Grażyna Nowaczyk}

Wyższa Szkoła Bankowa w Poznaniu

\section{Michal Pachocki}

Fundacja Rozwoju Systemu Edukacji, Warszawa

\section{Krzysztof Pietraszkiewicz}

Związek Banków Polskich, Warszawa

\section{Wojciech Piontek}

Uniwersytet Pedagogiczny

im. Komisji Edukacji Narodowej

w Krakowie

\section{Beata Platos}

Fundacja Rozwoju Systemu Edukacji, Warszawa

\section{Tomasz Rachwal}

Uniwersytet Pedagogiczny

im. Komisji Edukacji Narodowej

w Krakowie

Fundacja Warszawski

Instytut Bankowości

\section{Renata Rettinger}

Uniwersytet Pedagogiczny im. Komisji

Edukacji Narodowej w Krakowie

\section{Agnieszka Rybińska}

Fundacja Rozwoju Systemu Edukacji,

Warszawa

\section{Agnieszka Skala}

Politechnika Warszawska

\section{Anna Sobczak}

Akademia im. Jakuba z Paradyża

w Gorzowie Wielkopolskim

\section{Anna Śliwińska}

Fundacja Młodzieżowej

Przedsiębiorczości w Warszawie

\section{Marek Ziarko}

Zespół Szkół w Świątnikach Górnych 
Fundacja Rozwoju Systemu Edukacji (FRSE) funkcjonuje od 1993 r. Jest jedyną w Polsce instytucją z tak dużym doświadczeniem w zarządzaniu kilkunastoma edukacyjnymi programami europejskimi. W latach 2007-2013 koordynowała w Polsce programy "Uczenie się przez całe życie" (Erasmus, Leonardo da Vinci, Comenius i Grundtvig) oraz "Młodzież w działaniu". Obecnie pełni funkcję Narodowej Agencji Programu Erasmus+ na lata 2014-2020. Równolegle Fundacja realizuje europejskie inicjatywy informacyjno-edukacyjne, tj. eTwinning, Eurodesk Polska, Eurydice, Europass, ECVET i EPALE. Wspiera również współpracę z krajami Wschodu, poprzez Polsko-Litewski Fundusz Wymiany Młodzieży, Polsko-Ukraińską Radę Wymiany Młodzieży oraz Centrum Współpracy SALTO z Krajami Europy Wschodniej i Kaukazu. Od 2014 r. FRSE uczestniczy we wdrażaniu Programu Operacyjnego Wiedza Edukacja Rozwój.

Fundacja jest organizatorem wielu wydarzeń edukacyjnych, w tym konkursów, których celem jest promowanie rezultatów projektów (EDUinspiracje i EDUinspirator, European Language Label, SElfie+). Koordynuje obchody Europejskiego Tygodnia Młodzieży oraz współorganizuje wydarzenia odbywające się w ramach Europejskiego Dnia Języków. Prowadzi działalność analityczno-badawczą oraz wydawniczą (wydaje m.in. kwartalniki o tematyce edukacyjnej: Języki Obce w Szkole oraz Europa dla Aktywnych). 